\title{
Discovery of Novel Hedgehog Signaling Inhibitor
}

2015

Tomohiro Ohashi 


\section{Abbreviations} concentration time curve

AcOEt ethyl acetate

$\mathrm{AcOH} \quad$ acetic acid

$\mathrm{AcONa}$ sodium acetate

BCC basal cell carcinoma

BID bis in die

$\mathrm{BnEt}_{3} \mathrm{NCl}$ benzyltriethylammonium chloride

Boc

$\mathrm{Boc}_{2} \mathrm{O}$ di-tert-butyl dicarbonate

CL clearance

$\mathrm{C}_{\max } \quad$ maximum concentration

DBU 1,8-diazabicyclo[5.4.0]undec-7-ene

DMA N,N-dimethylacetamide

DME 1,2-dimethoxyethane

DMF $\quad N, N$-dimethylformamide

DMSO dimethylsulfoxide

Dhh Desert hedgehog

EDC 1-ethyl-3-(3-dimethylaminopropyl)carbodiimide hydrochloride

$\mathrm{Et}_{2} \mathrm{O} \quad$ diethyl ether

$\mathrm{Et}_{3} \mathrm{~N} \quad$ trimethylamine

hERG human ether-a-go-go related gene

HOBt 1-hydroxybenzotriazole

HTS high-throughput screening

Hh hedgehog

HhL hedgehog ligand

IPE diisopropyl ether

Ihh Indian hedgehog

LC-MS liquid chromatography-mass spectrometry

$m$ CPBA $m$-chloroperbenzoic acid

MePhos 2-(dicyclohexylphosphino)-2'methylbiphenyl

MOE molecular operating environment $m$ RNA messenger ribonucleic acid

MRT mean residence time

$\mathrm{MeOH}$ methanol

NBS $\quad N$-bromosuccinimide

$\mathrm{NH}_{4} \mathrm{OAc}$ ammonium acetate

NMR nuclear magnetic resonance

OTf triflate

PD pharmacodynamic

PK pharmacokinetic

PMB $\quad p$-methoxybenzyl

$\mathrm{Pd}\left(\mathrm{PPh}_{3}\right)_{4} \quad$ tetrakis(triphenylphosphine)-

palladium(0)

$\mathrm{Pd} / \mathrm{C} \quad$ palladium/carbon

$\mathrm{Pd}_{2}(\mathrm{dba})_{3} \quad$ tris(dibenzylideneacetone)-

dipalladium $(0)$

$\mathrm{Pd}(\mathrm{OAc})_{2}$ palladium(II) acetate

$\mathrm{Ph} \quad$ phenyl

Ptch patched

QD quaque die

rt room temperature

SAR structure-activity relationship

$\pm \mathrm{SD} \quad$ standard deviation

Shh Sonic hedgehog

Smo smoothened

$\mathrm{T} / \mathrm{C} \quad$ treatment/control ratio

tert-BuONa sodium tert-butoxide

TFA trifluoroacetic acid

TFAA trifluoroacetic anhydride

THF tetrahydrofuran

$\mathrm{Tf}_{2} \mathrm{O} \quad$ trifluoromethanesulfonic anhydride

$\mathrm{TfOH} \quad$ trifluoromethanesulfonic acid

Vss steady state volume of distribution

xantphos 4,5-bis(diphenylphosphino)-9,9-

dimethylxanthene 


\section{INDEX}

\section{Introduction}

1.1. Current status of cancer therapy 1

1.2. Molecular targeted drug and signal transduction 2

1.3. Hedgehog signal and cancer 3

1.4. Small molecule Hh signaling inhibitors 4

1.5. The strategy for drug discovery 5

Chapter I. Discovery of pyrrolo[3,2-c]quinoline-4-one derivatives

2.1. Introduction $\quad 7$

2.2. Synthesis 7

2.3. Results and discussion

2.3.1. Biological data for hedgehog, and SAR study 9

2.3.2. Pharmacodynamic, pharmacokinetic data and in vivo study of $\mathbf{1 2 b}$ in mouse 12

2.4. Conclusion 13

Chapter II. Discovery of TAK-441 as orally available candidate

3.1. Introduction 15

3.2. Synthesis 16

3.3. Results and discussion

3.3.1. Biological data for hedgehog, and SAR study 19

3.3.2. X-ray single crystal structure analysis of 22d 21

3.3.3. In vivo study of 22d 22

3.3.4. Pharmacokinetic data of 22d in other animals 24

3.4. Conclusion 24

Chapter III. Synthesis and evaluation of hedgehog signaling inhibitor with novel core system

4.1. Introduction 25

4.2. Synthesis 26

4.3. Results and discussion 
4.3.1. Biological data for hedgehog, and SAR study 33

4.3.2. Pharmacodynamic and pharmacokinetic data of 25c-25f 36

4.4. Conclusion 37

$\begin{array}{ll}\text { Summary } & 38\end{array}$

$\begin{array}{ll}\text { Acknowledgement } & 40\end{array}$

Experimental section $\quad 41$

General Methods 41

Experimental section of chapter I 42

Experimental section of chapter II 53

Experimental section of chapter III $\quad 65$

$\begin{array}{ll}\text { Assay protocols } & 83\end{array}$

$\begin{array}{ll}\text { Gli-luciferase assay } & 83\end{array}$

Smo binding assay $\quad 83$

$\begin{array}{ll}\text { In vivo pharmacodynamic assay } & 84\end{array}$

In vivo anti-tumor test $\quad 84$

$\begin{array}{ll}\text { In vitro metabolism with hepatic microsomes } & 84\end{array}$

$\begin{array}{ll}\text { Pharmacokinetic studies in mice } & 85\end{array}$

$\begin{array}{ll}\text { Pharmacokinetic studies in rats and dogs } & 85\end{array}$

$\begin{array}{ll}\text { X-ray structure analysis } & 85\end{array}$

$\begin{array}{ll}\text { References } & 87\end{array}$

$\begin{array}{ll}\text { List of publications } & 90\end{array}$ 


\section{Introduction}

\subsection{Current status of cancer therapy}

Recently, cancer becomes a curable disease owing to discovery of many therapeutic options. The major therapeutic options consist of operation therapy, radiation therapy and chemotherapy, and the combination of these options is used for the treatment in many cases. The recent development of these therapeutic options contributes to cure some kinds of cancer, for example advanced cancer, micro cancer, and metastatic cancer. But some problems were still left in each options. The operation therapy is not suitable in case of metastatic cancer, and stressed physically or mentally to patients. In radiation therapy, the radiation hazards is concerned. In chemotherapy, generally used anticancer drug has a problem of adverse effect which triggered to interact with normal cells as well as cancer cells.

\begin{tabular}{|c|c|c|}
\hline & \multicolumn{2}{|c|}{ Therapeutic options of cancer } \\
\hline $\begin{array}{l}\text { Operation therapy } \\
\text { advantage } \\
\text {-extirpate a tumor } \\
\text { in advanced cancer } \\
\text { disadvantage } \\
\text { 'necessary to wound } \\
\text {-cannot cure where the operation }\end{array}$ & $\begin{array}{l}\text { Radiation therapy } \\
\text { advantage } \\
\text {-possible to treat } \\
\text { in micro cancer } \\
\text { disadvantage } \\
\text { 'possibility of radiation hazards }\end{array}$ & $\begin{array}{l}\text { Chemotherapy } \\
\text { advantage } \\
\text {-oral administration } \\
\text { - effective to small metastatic cancer } \\
\text { disadvantage } \\
\text {-adverse effect triggered to the effects } \\
\text { on normal cell }\end{array}$ \\
\hline
\end{tabular}

Figure 1. Therapeutic options of cancer.

To dissolve these problems, technical or chemical approaches are developed. Laparoscopic or endoscopic operation lowers the patients' stress in operation therapy. A technique of pinpoint radiation to the tumor can decrease the radiation hazards in radiation therapy. In chemotherapy, a molecular targeted drug is developed to decrease the adverse effect. The molecular targeted drug has been developed over the past decades, and enhances the growth inhibition or malfunction to interact with protein specifically expressed in cancer cell. For this selective interaction with cancer cell, the molecular targeted drug is expected to have less adverse effect. 


\subsection{Molecular targeted drug and signal transduction}

A molecular targeted drug consists of small molecular drug and antibody drug. An antibody drug has been developed since the technology development of monoclonal antibody in 1970's. ${ }^{1}$ The antibody drug binds to an antigen specifically exists in the surface of cancer cell, and inhibits the function. The molecular weight of antibody drug is too big, thus mainly developed as injections. On the other hands, a small molecular drug has been developed from the late of 1990's. In contrast to antibody drug, the small molecule drug has advantages to pass through the cell membrane, and develop as oral drug owing to low molecular weight.

Many small molecular drugs have already approved by Food and Drug Administration (FDA). ${ }^{2}$ Bcr-Abl protein is specifically overexpressed in chronic myelogenous leukemia (CML) cells and leads to abnormal signal transduction for cell proliferation. Imatinib ${ }^{3}$ is the Bcr-Abl protein targeted drug for the inhibition of this signal transduction. Epidermal growth factor receptor (EGFR) is a receptor tyrosine kinase, its activation occurred by stimulation with EGF. It induces the signal transduction to Ras/RAF/MAPK pathway and PI3K/Akt pathway which play an important role for cell proliferation and cell growth. Gefitinib ${ }^{4}$ inhibits these signaling pathways in non-small cell lung cancer (NSCLC) (Figure 2).

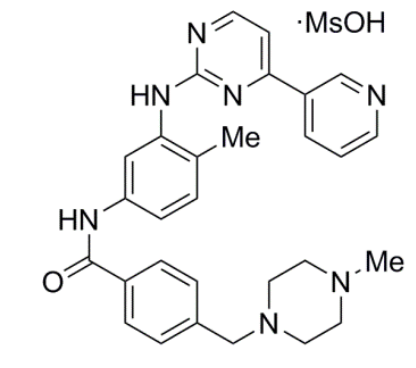

Imatinib

(Bcr/Abl tyrosine kinase inhibitor)

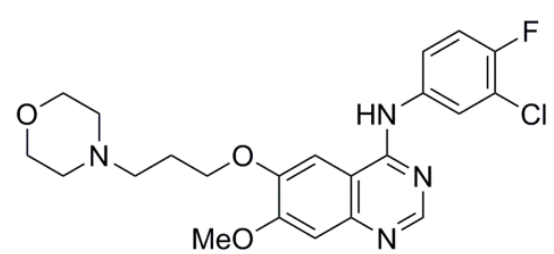

Gefitinib

(EGFR tyrosine kinase inhibitor)

Figure 2. Chemical structures of major small molecular drugs. 


\subsection{Hedgehog signal and cancer}

Pancreatic cancer is difficult to discover in early stage because any symptoms are not appeared. Thus the cancer cannot be found until terminal stage in many cases, 5 -year survival rate of pancreatic cancer is quite low compared to other cancers. In addition to few drugs for pancreatic cancer, it is hard to cure a pancreatic cancer completely by only operation therapy. Therefore, the development of novel therapeutic method is expected.

In 2003, Thayer et al. reported that hedgehog (Hh) signaling is expressed abnormally in pancreatic cancer cells, and may also be an important mediator in pancreatic carcinoma. $^{5}$

Hh signaling plays an essential role for in cell proliferation and differentiation during embryonic development. In mammal, three ligands of hedgehog signaling are identified, i.e. Sonic hedgehog (Shh), Desert hedgehog (Dhh), and Indian hedgehog (Ihh). Among these ligands, Shh expressed across the whole body is most developed. In the normal state, twelve-transmembrane receptor protein Patched (Ptch) suppresses the activation of seven-transmembrane signal component protein Smoothened (Smo $)^{6}$ resulted to the inhibition of signal transduction to downstream. When the Hh ligand $(\mathrm{HhL})$ exists, the activation of Smo is triggered by suppression of Ptch with Shh binding. It causes signal transduction, and upregulates Gli transcription activity. Subsequently, genes under the control of Gli activate downstream signals that contribute to cellular proliferation and differentiation.

This signaling pathway is inactive in most adult tissues; however, aberrant activation driven by Ptch-defective mutations or Hh-ligand overexpression have been detected in certain types of cancers. ${ }^{7}$ In the mutation-driven mechanism, tumor growth is enhanced by autonomous activation of Gli caused by constitutive Smo activation due to loss of Ptch function. This mechanism has been observed in medulloblastoma ${ }^{8}$ and basal cell carcinoma (BCC). ${ }^{9}$ In the Hh-ligand driven mechanism, the overexpression of Hh ligand in cancer cells leads to abnormal activation of Gli in neighboring stromal cells, and induces the enhancement of tumor growth by a paracrine mechanism. ${ }^{10}$ This mechanism has been detected in a wide range of solid tumors including colon, ${ }^{11}$ prostate, ${ }^{12}$ and pancreatic cancers (Figure 3 ). ${ }^{13}$ 


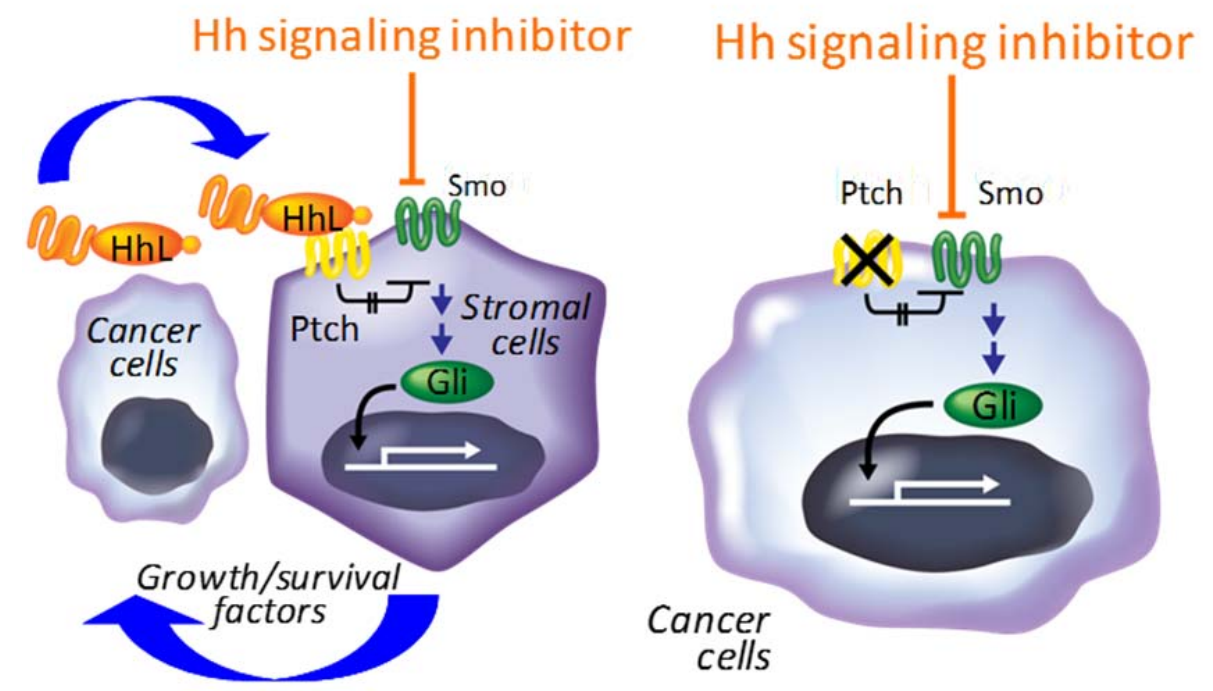

Figure 3. Aberrant activation of Hh signaling pathway in cancer.

\subsection{Small molecule Hh signaling inhibitors}

To date, several small molecule Hh signaling inhibitors have been identified (Figure 4). Cyclopamine, a steroid jerveratum alkaloid derived from corn lily, showed significant activity in Hh signaling pathway inhibition ${ }^{14}$ and directly interacts with Smo protein, thereby inhibiting tumor growth in several cancer cell types. The synthetic small molecule Hh signaling inhibitor, vismodegib ${ }^{15}$ has been approved by FDA in locally advanced or metastatic BCC. Sonidegib ${ }^{16}$ was discovered by Novartis which has also approved in locally advanced or metastatic BCC. Other compounds in development include a cyclopamine-derivative, saridegib (IPI-926), ${ }^{17}$ a synthetic compound, NVP-LEQ506, ${ }^{18} \mathrm{PF}-04449913,{ }^{19}$ and LY-2940680. ${ }^{20}$ 

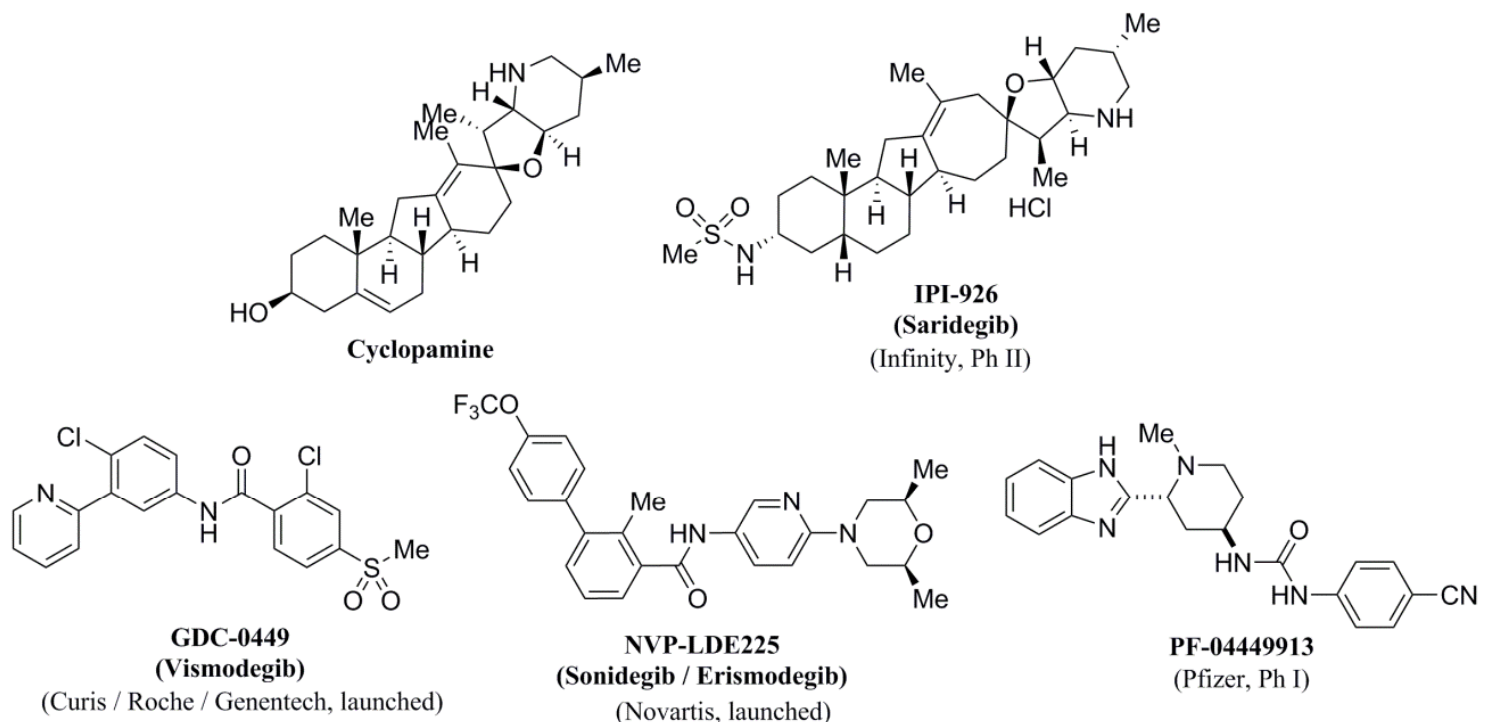

$$
\text { NVP-LDE225 }
$$

(Sonidegib / Erismodegib)

(Novartis, launched)
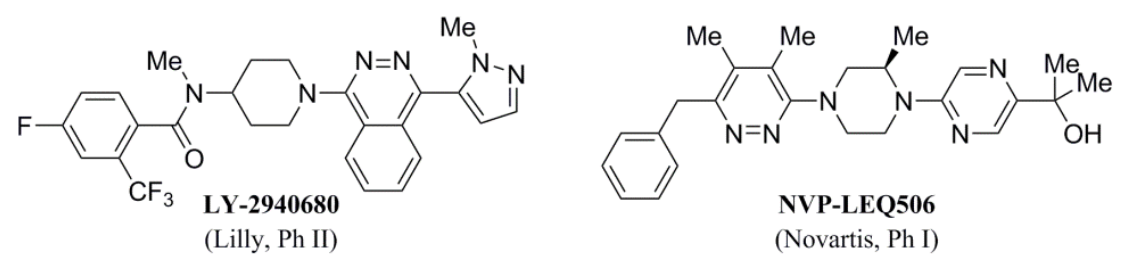

Figure 4. Various small molecule Hh signaling inhibitors.

\subsection{The strategy for drug discovery}

Based on these results, it has been suggested that an Hh signaling inhibitor may be useful as a therapeutic agent for many kinds of cancers. Therefore, the discovery of novel and potent $\mathrm{Hh}$ signaling inhibitor which is structurally different from known compounds was started (Figure 5).

In chapter I, the discovery of pyrrolo[3,2-c]quinoline-4-one derivative 12b and its result of in vivo study are included. The modification of thieno[3,2-c]quinoline-4-one derivative 1a identified by high-throughput screening (HTS) was conducted at the upper part to improve stability in mouse and human microsomes while considering to metabolite analysis. The results of Smo binding assay and in vivo study are also included.

In chapter II, the discovery of pyrrolo[3,2- $d]$ pyridine-4-one derivative 22d (TAK-441) and the result of in vivo study are described. Because of plateaued pharmacokinetic data in high-dose of $\mathbf{1 2 b}$, the modification at core ring was conducted to improve solubility. The pharmacokinetic study in rats and dogs also conducted.

In chapter III, some novel Hh signaling inhibitors 25c-f are discovered by further modification of 22d at lower part by using X-ray single crystal structure analysis. These compounds showed potent Gli reporter inhibitory activity comparable to 22d. From the 
comparison of pharmacokinetics among 22d and novel inhibitors 25c-f, 22d showed the best pharmacokinetic profile, and was selected as a clinical candidate.

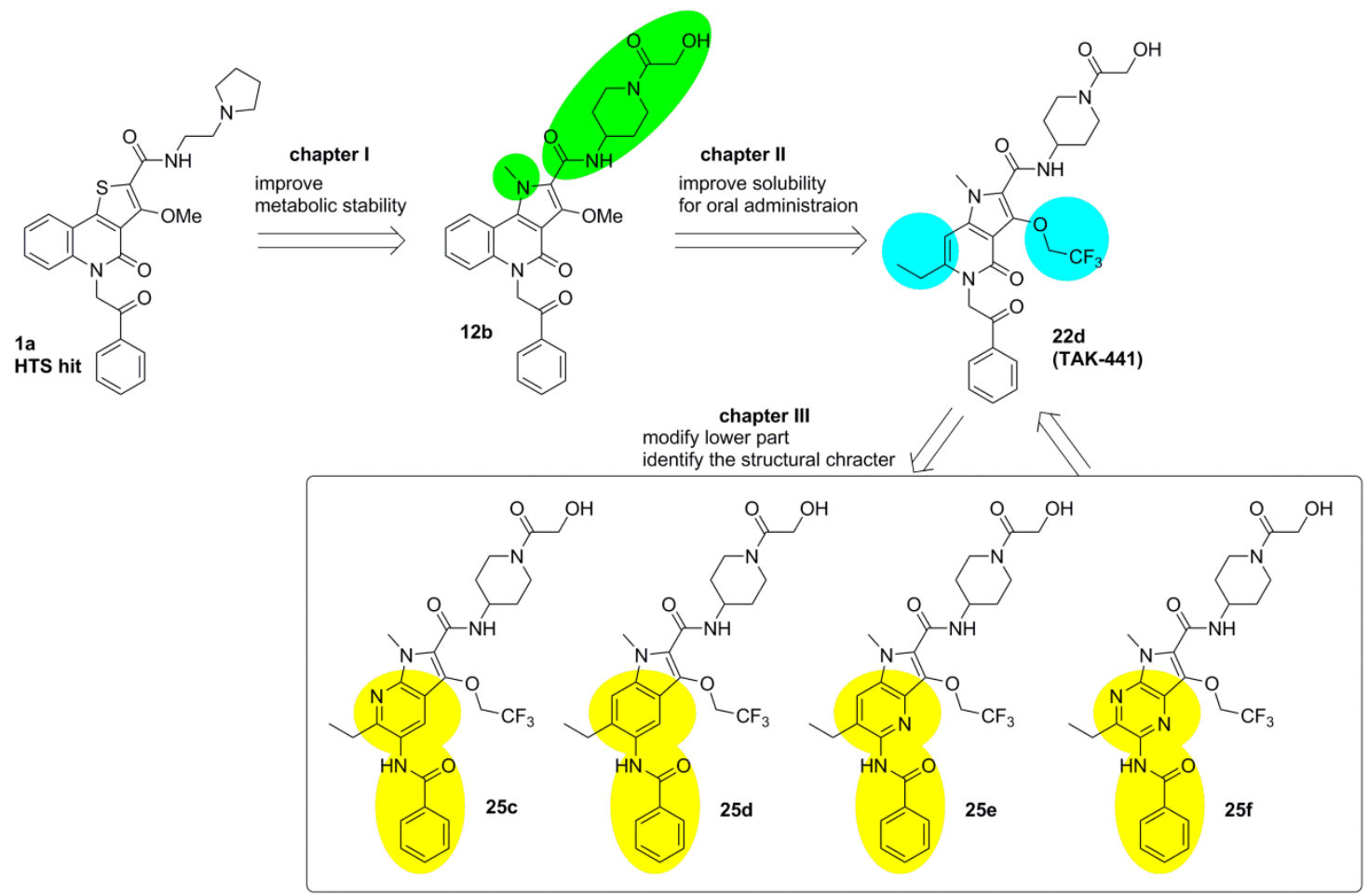

Figure 5. Synthetic strategy and representative compound in each chapter. 


\section{Chapter I}

\section{Discovery of pyrrolo[3,2-c]quinoline-4-one derivatives}

\subsection{Introduction}

Thieno[3,2-c]quinoline-4-one derivative 1a was identified as a $\mathrm{Hh}$ signaling inhibitor by HTS of the compound library in Takeda Pharmaceutical Company. The chemical structure of $\mathbf{1 a}$ is distinct from those of known $\mathrm{Hh}$ signaling inhibitors currently in clinical trials. Compound 1a demonstrated potent inhibition of Hhactivity with an $\mathrm{IC}_{50}$ of $5.1 \mathrm{nM}$ in the Gli-luc reporter assay; however 1a was unstable in mouse hepatic microsome. In the metabolite analysis, the oxidation of the amide moiety was observed in mouse hepatic microsome, thus the chemical modifications of 1a focused on amide moiety in an effort to enhance metabolic stability while maintaining in vitro activity were conducted (Figure 6). In this chapter, the synthesis and structure-activity relationship (SAR) of this new class of Hh signaling inhibitors are described.
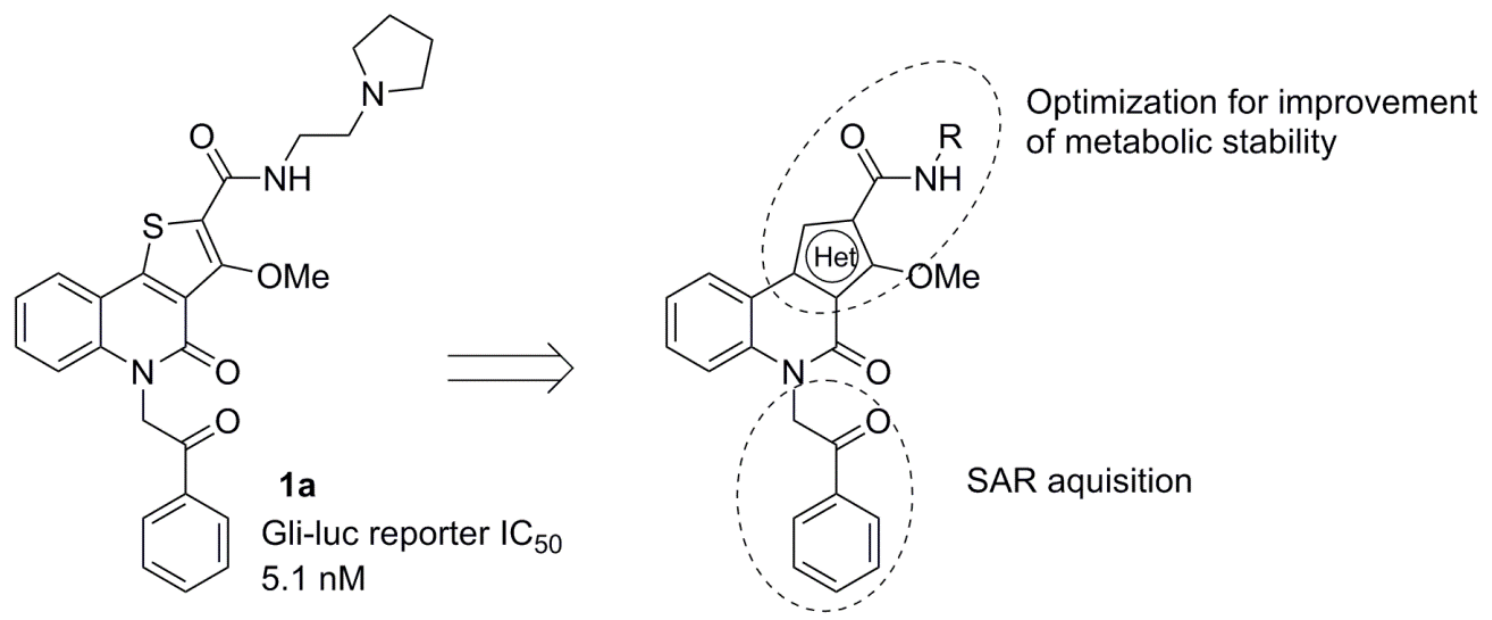

Figure 6. Structure of a hit compound 1a and synthetic strategy.

\subsection{Synthesis}

Thieno-, pyrrolo-, furo-[3,2-c]quinoline-4-one derivatives were prepared as shown in Scheme 1 and Scheme 2. Treatment of methyl anthranilate 2 with diethyl malonate under basic conditions gave quinoline compound 2. Chlorination of $\mathbf{3}$ using phosphoryl chloride was achieved in 79\% yield. Hydrolysis of 4 with sodium acetate led to 4-chloroquinoline 5 selectively, which was $N$-alkylated with phenacyl bromide or $p$-methoxybenzyl chloride to afford $\mathbf{6 a}, \mathbf{b}$. The tricyclic core ring was constructed by treatment of $\mathbf{6}$ with corresponding ester reagent under basic conditions. Alkylation of 
hydroxyl group of 7 afforded alkoxy derivative 8, and following hydrolysis gave derivative 9. Carboxylic acid $\mathbf{9}$ was converted to various amides (1a-h) by condensation with corresponding amines, 1-ethyl-3-(3-dimethylaminopropyl)carbodiimide hydrochloride (EDC) and 1-hydroxybenzotriazole (HOBt) in 18-93\% yield. Piperidine derivative $\mathbf{1} \mathbf{i}$ was afforded by removal of the Boc group of $\mathbf{1 h}$ with $\mathrm{HCl}$ (Scheme 1).

Scheme 1. Synthesis of thieno-, pyrrolo-, furo-[3,2-c]quinoline-4-one derivatives.<smiles>CC(=O)c1ccccc1N</smiles>

2

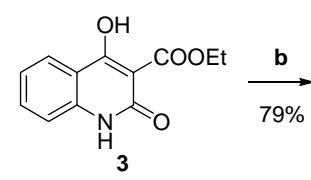

3

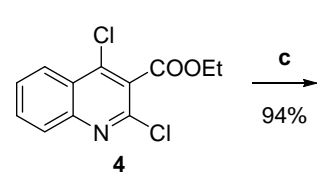

4

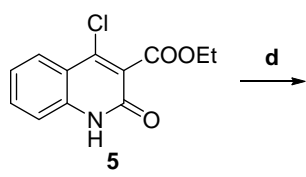

6a $\left(71 \%, \mathrm{R}^{1}=\mathrm{CH}_{2} \mathrm{COPh}\right)$

6b $\left(79 \%, \mathrm{R}^{1}=\mathrm{PMB}\right)$

$\mathrm{R}^{1}$
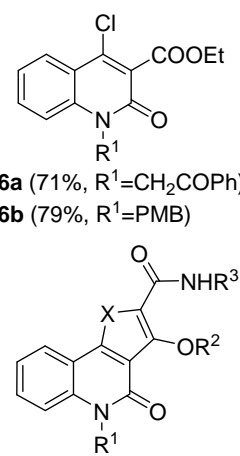

1a-i

7a (96\%, X=S, $\left.\mathrm{R}^{1}=\mathrm{CH}_{2} \mathrm{COPh}\right) \quad \mathbf{8 a}\left(79 \%, X=\mathrm{S}, \mathrm{R}^{1}=\mathrm{CH}_{2} \mathrm{COPh}, \mathrm{R}^{2}=\mathrm{Me}\right) \quad$ 9a $\left(79 \%, X=\mathrm{S}, \mathrm{R}^{1}=\mathrm{CH}_{2} \mathrm{COPh}, \mathrm{R}^{2}=\mathrm{Me}\right)$ 7b $\left(69 \%, X=\mathrm{O}, \mathrm{R}^{1}=\mathrm{CH}_{2} \mathrm{COPh}\right) \quad \mathbf{8 b}\left(23 \%, \mathrm{X}=\mathrm{O}, \mathrm{R}^{1}=\mathrm{CH}_{2} \mathrm{COPh}, \mathrm{R}^{2}=\mathrm{Me}\right) \quad$ 9b $\left(72 \%, \mathrm{X}=\mathrm{O}, \mathrm{R}^{1}=\mathrm{CH}_{2} \mathrm{COPh}, \mathrm{R}^{2}=\mathrm{Me}\right)$ 7c $\left(66 \%, X=N M e, R^{1}=C_{2}\right.$ COPh) 8c (55\%, X=NMe, $\left.R^{1}=\mathrm{CH}_{2} \mathrm{COPh}, \mathrm{R}^{2}=\mathrm{Me}\right) 9 \mathrm{c}\left(91 \%, \mathrm{X}=\mathrm{NMe}, \mathrm{R}^{1}=\mathrm{CH}_{2} \mathrm{COPh}, \mathrm{R}^{2}=\mathrm{Me}\right)$ 7d $\left(81 \%, X=N M e, R^{1}=P M B\right) \quad 8 d\left(100 \%, X=N M e, R^{1}=C_{2}\right.$ COPh, $\left.R^{2}=E t\right) 9 d\left(89 \%, X=N M e, R^{1}=C_{2} C_{2} C O P h, R^{2}=E t\right)$ 8e $\left(61 \%, X=N M e, R^{1}=P M B, R^{2}=M e\right) \quad 9 e\left(96 \%, X=N M e, R^{1}=P M B, R^{2}=M e\right)$

\begin{tabular}{|c|c|c|c|c|c|}
\hline cmpds. & $\mathrm{X}$ & $\mathrm{R}^{1}$ & $\mathrm{R}^{2}$ & $\mathrm{R}^{3}$ & yield (\%) \\
\hline 1a & $\mathrm{S}$ & $\mathrm{CH}_{2} \mathrm{COPh}$ & $\mathrm{Me}$ & & 62 \\
\hline $1 b$ & $\mathrm{O}$ & $\mathrm{CH}_{2} \mathrm{COPh}$ & $\mathrm{Me}$ & & 66 \\
\hline 1c & $\mathrm{NMe}$ & $\mathrm{CH}_{2} \mathrm{COPh}$ & $\mathrm{Me}$ & & 78 \\
\hline 1d & $\mathrm{NMe}$ & $\mathrm{CH}_{2} \mathrm{COPh}$ & $\mathrm{Et}$ & & 18 \\
\hline $1 e$ & $\mathrm{NMe}$ & $\mathrm{CH}_{2} \mathrm{COPh}$ & $\mathrm{Me}$ & & 90 \\
\hline 1f & $\mathrm{NMe}$ & $\mathrm{CH}_{2} \mathrm{COPh}$ & $\mathrm{Me}$ & & 82 \\
\hline $1 \mathrm{~g}$ & $\mathrm{NMe}$ & $\mathrm{CH}_{2} \mathrm{COPh}$ & $\mathrm{Me}$ & & 85 \\
\hline$-1 h$ & $\mathrm{NMe}$ & PMB & $\mathrm{Me}$ & & 93 \\
\hline $1 i$ & $\mathrm{NMe}$ & PMB & $\mathrm{Me}$ & & $99^{1)}$ \\
\hline
\end{tabular}

Reagents and conditions: (a) diethyl malonate, NaOEt, EtOH, rt then $140{ }^{\circ} \mathrm{C}$; (b) $\mathrm{POCl}_{3}, 110^{\circ} \mathrm{C}$; (c) AcONa, AcOH, $120{ }^{\circ} \mathrm{C}$; (d) $\mathrm{PhCOCH}_{2} \mathrm{Br}$, NaH, DMF, rt for 6a, or PMBCl, NaH, DMF, rt for $6 \mathbf{b}$; (e) $\mathrm{EtOOCCH}_{2} \mathrm{SH}$ for $\mathbf{7 a}$ or EtOOCCH${ }_{2} \mathrm{OH}$ for $\mathbf{7 b}, \mathrm{NaOEt}, \mathrm{EtOH}$, rt; (f) (1) $\mathrm{MeNHCH}_{2} \mathrm{COOEt} \cdot \mathrm{HCl}_{1}, \mathrm{Et}_{3} \mathrm{~N}$, $\mathrm{EtOH}, 85{ }^{\circ} \mathrm{C}$; (2) NaOEt, EtOH, $50{ }^{\circ} \mathrm{C}$ for $7 \mathrm{c}$; (g) $\mathrm{MeNHCH}_{2} \mathrm{COOEt} \cdot \mathrm{HCl}, \mathrm{Et}_{3} \mathrm{~N}$, EtOH, $85{ }^{\circ} \mathrm{C}$ then $\mathrm{NaOEt}$, EtOH, $60^{\circ} \mathrm{C}$ for 7d; (h) MeI or EtI, DBU, DMF, rt.; (i) $\mathrm{NaOH}$, EtOH, $\mathrm{H}_{2} \mathrm{O}$, rt; (j) $\mathrm{R}^{3} \mathrm{NH}_{2}, \mathrm{EDC}$, $\mathrm{HOBt}, \mathrm{Et}_{3} \mathrm{~N}$, DMF; (k) HCl, AcOEt, rt. 
$N$-Hydroxyethyl 12a and $N$-hydroxyacetyl 12b derivatives were obtained from $\mathbf{1 g}$ by its alkylation or acylation in $33 \%$ and $51 \%$ yield, respectively. $1 \mathbf{i}$ was alkylated with 2-bromoethanol to afford 10, and the removal of the $p$-methoxybenzyl group was carried out with trifluoroacetic acid (TFA), anisole, and trifluoromethanesulfonic acid (TfOH) at $80{ }^{\circ} \mathrm{C}$, followed by acetylation to give 11. $N$-alkylation of $\mathbf{1 1}$ using the corresponding alkyl halides in the presence of sodium tert-butoxide (tert-BuONa) followed by hydrolysis of the acetyl group gave 12c, 12d in $15 \%$ and $2.4 \%$ yield, respectively (Scheme 2).

Scheme 2. Synthesis of 12a-d.
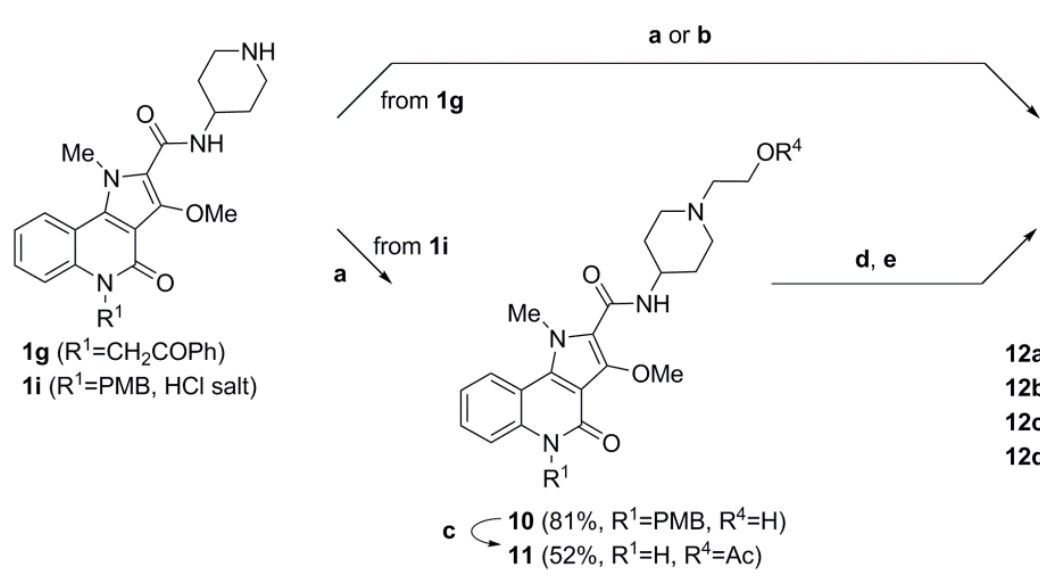

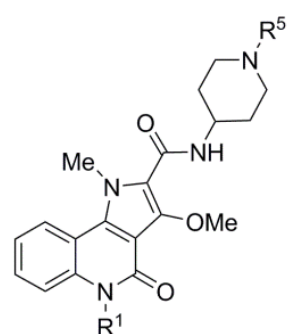

12a $\left(33 \%, \mathrm{R}^{1}=\mathrm{CH}_{2} \mathrm{COPh}, \mathrm{R}^{5}=\mathrm{CH}_{2} \mathrm{CH}_{2} \mathrm{OH}\right)$ 12b $\left(51 \%, \mathrm{R}^{1}=\mathrm{CH}_{2} \mathrm{COPh}, \mathrm{R}^{5}=\mathrm{COCH}_{2} \mathrm{OH}\right)$ 12c $\left(15 \%, \mathrm{R}^{1}=\mathrm{CH}_{2} \mathrm{COEt}, \mathrm{R}^{5}=\mathrm{CH}_{2} \mathrm{CH}_{2} \mathrm{OH}\right)$ 12d $\left(2.4 \%, \mathrm{R}^{1}=\mathrm{CH}_{2} \mathrm{CH}_{2} \mathrm{Ph}, \mathrm{R}^{5}=\mathrm{CH}_{2} \mathrm{CH}_{2} \mathrm{OH}\right)$

Reagents and conditions: (a) 2-bromoethanol, $\mathrm{K}_{2} \mathrm{CO}_{3}, \mathrm{DMF}, 80{ }^{\circ} \mathrm{C}$ for $10,100{ }^{\circ} \mathrm{C}$ for 12a; (b) (1) $\mathrm{ClCOCH}_{2} \mathrm{OAc}, \mathrm{Et}_{3} \mathrm{~N}$, THF, $0{ }^{\circ} \mathrm{C}$, (2) $\mathrm{NaOH}$, EtOH, rt; (c) (1) TFA, anisole, TfOH, $80{ }^{\circ} \mathrm{C}$; (2) $\mathrm{AcCl} \mathrm{Et}_{3} \mathrm{~N}$, THF, $0{ }^{\circ} \mathrm{C}$; (d) $\mathrm{EtCOCH}_{2} \mathrm{Br}$ or $\mathrm{PhCH}_{2} \mathrm{CH}_{2} \mathrm{Br}$, tert-BuONa, $\mathrm{LiBr}, \mathrm{DME} / \mathrm{DMF}, 0{ }^{\circ} \mathrm{C}$ to rt. (e) $\mathrm{NaOH}, \mathrm{EtOH}$, $\mathrm{H}_{2} \mathrm{O}$, rt.

\subsection{Results and discussion}

\subsubsection{Biological data for hedgehog, and SAR study}

The in vitro effects of the tricyclic core on activity (Table 1) were initially assessed by using a luciferase reporter in NIH3T3 cells carrying a stably transfected Gli-reporter construct (Gli-luc reporter cell line). ${ }^{21}$ The furo analog $\mathbf{1 b}$ clearly had decreased Hh inhibitory activity compared with 1a. On the other hand, a significant increase in Hh inhibition was observed with $N$-methylpyrrolo analog $\mathbf{1 c}$ compared to $\mathbf{1 b}$. $\mathrm{N}$-methyl moiety of the 5-membered ring was considered to be essential for potent activity and metabolic stability based on the low lipophilicity. Thus $\mathrm{N}$-methylpyrrolo[3,2-c] quinoline-4-one was selected as a core ring system for further investigation. 
Table 1. Effect of tricyclic ring core against Gli-luc reporter assay.

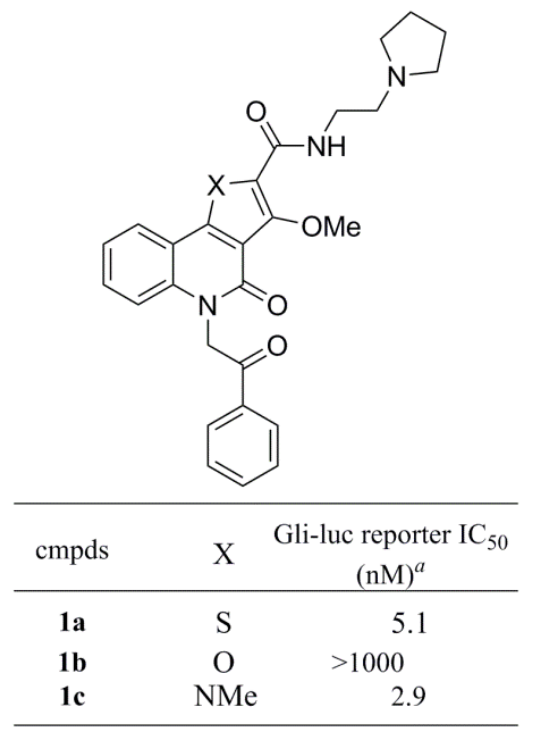

${ }^{a} \mathrm{IC}_{50}$ values represent the mean of four measurements.

Although 1c showed potent in vitro activity as mentioned above, the metabolic stability of this compound assessed by incubation in mouse hepatic microsomes was still insufficient to suggest that 1c would have in vivo efficacy in mice (Table 2). Thus, our interest was shifted to improvement of the metabolic stability by optimization of the substituents at the 2, 3, 5-positions of the pyrrolo[3,2-c]quinoline-4-one. Substitution of methoxy group at the 3-position reduced activity and was apparently unstable in mouse hepatic microsomes (1d vs 1c). Therefore, the substituent at this position was fixed as methoxy in the remaining studies. Several derivatives were prepared with various cyclic amines at the terminal of the side chain at the 2-position. Ethyl groups with piperidine (1e) or morpholine (1f) derivatives resulted in decreased Gli-luc reporter inhibitory activity without improvement of metabolic stability. The 4-piperidinyl derivative $\mathbf{1 g}$ showed dramatic improvement in metabolic stability compared to 1c, indicating that the cyclic amine component attached directly to the amide linker decreased lipophilicity and improved metabolic stability. The side chain of $\mathbf{1 g}$ is shorter than that of $\mathbf{1 c}$ and the author speculated that introduction of the ethyl group on to the nitrogen of the piperidine ring in $\mathbf{1 g}$ was responsible for enhancing activity. The overlays of the stable conformation of $\mathbf{1 g}$ and ethylated $\mathbf{1 g}$ (Et-1g) calculated by Molecular Operating Environment (MOE) software were shown in Figure 7. It demonstrated that the ethyl group of Et-1g could occupy the same space as the pyrrolidine ring of 1c. The lipophilicity of Et-1g was predicted to be higher than that of $\mathbf{1 g}$ (cLogP value : Et-1g= 3.5 vs $\mathbf{1 g}=2.5$ ), suggesting that Et-1g may have decreased microsomal stability as a 
result. Thus a hydroxyethyl substituent (clogP value: 2.2 ) onto the piperidine nitrogen of $1 \mathrm{~g}$ instead of the ethyl group position was introduced. As expected, 12a demonstrated potent inhibition of Gli-luc reporter activity while retaining metabolic stability both in mouse and human microsomes. However, further evaluation of 12a showed strong inhibition of the human ether-a-go-go related gene (hERG; data not shown) which is involved in cardiac repolarization. Since basicity of compounds is often correlated with hERG inhibition, ${ }^{22}$ the acyl function was introduced to decrease basicity. Compound 12b, bearing a $N$-[1-(hydroxyacetyl)piperidinyl] amide moiety, achieved both potent activity and good metabolic stability without hERG inhibition, as expected.

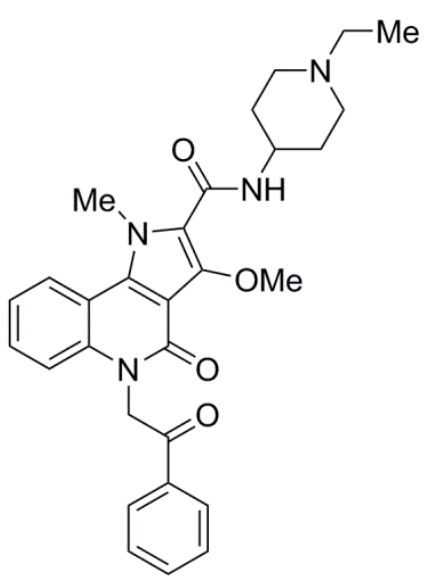

Et-1g

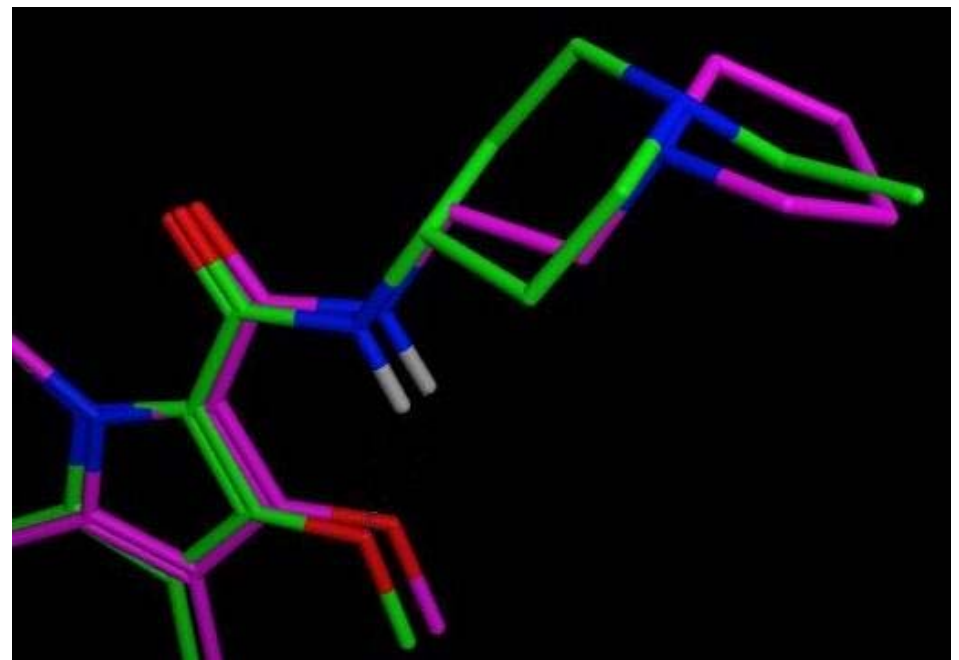

Figure 7. Overlay of ethylated 1g (Et-1g, green) and 1c (purple) in stable conformation calculated by MOE software. ${ }^{a}$

${ }^{a}$ MOE version 2010.10; Chemical Computing Group, Inc., Montreal, Quebec, Canada. ClogP values, which indicate the index of lipophilicity, were calculated by Daylight Software ClogP, version 4.82, Daylight Chemical Information Systems, Inc., Aliso Viejo, CA.

Finally, the SAR around the 5-position was investigated. The 2-butanoyl derivative 12c, which had an ethyl group in place of the benzene ring in $\mathbf{1 2 b}$, exhibited significantly decreased potency. The phenethyl derivative 12d without the carbonyl group showed 30 -fold drop in activity compared with 12a. These results suggested that an aromatic substituent at the 5-position would be necessary for tight binding to the Smo protein. Therefore, the phenacyl group in 12b was selected as the best substituent at the 5-position for further evaluation. 
Table 2. Effect of substituents on pyrrolo[3,2-c]quinoline-4-one at 2, 3, and 5-position.

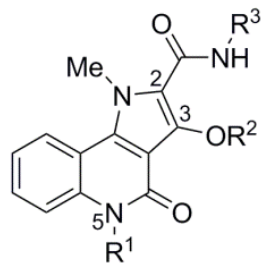<smiles>CCC(=O)CBr</smiles><smiles>[SiH3]</smiles><smiles>CCCc1ccccc1</smiles>

\begin{tabular}{|c|c|c|c|c|c|c|}
\hline \multirow{2}{*}{ cmpds } & \multirow{2}{*}{$\mathrm{R}^{1}$} & \multirow{2}{*}{$\mathrm{R}^{2}$} & \multirow{2}{*}{$\mathrm{R}^{3}$} & \multirow{2}{*}{$\begin{array}{l}\text { Gli-luc reporter } \mathrm{IC}_{50} \\
(\mathrm{nM})^{a}\end{array}$} & \multicolumn{2}{|c|}{ metabolic stability ${ }^{b}(\mu \mathrm{L} / \mathrm{min} / \mathrm{mg})$} \\
\hline & & & & & Mouse & Human \\
\hline 1c & A & $\mathrm{Me}$ & & 2.9 & 95 & 14 \\
\hline $1 d$ & A & Et & & 7.0 & 155 & 26 \\
\hline $1 \mathrm{e}$ & A & $\mathrm{Me}$ & & 9.6 & 192 & 30 \\
\hline 1f & A & $\mathrm{Me}$ & & 22 & 237 & 73 \\
\hline $1 \mathrm{~g}$ & A & $\mathrm{Me}$ & & 21 & 10 & 2 \\
\hline 12a & A & $\mathrm{Me}$ & & 6.6 & 9 & 6 \\
\hline $12 \mathrm{~b}$ & A & $\mathrm{Me}$ & & 4.6 & 11 & 0 \\
\hline $12 \mathrm{c}$ & B & $\mathrm{Me}$ & & $>1000$ & 0 & 3 \\
\hline $12 \mathrm{~d}$ & $\mathrm{C}$ & $\mathrm{Me}$ & & 150 & 48 & 72 \\
\hline
\end{tabular}

${ }^{a} \mathrm{IC}_{50}$ values are the mean of four measurements. ${ }^{b}$ Hepatic microsome.

\subsubsection{Pharmacodynamic, pharmacokinetic data and in vivo study of $\mathbf{1 2 b}$ in mouse}

The in vivo pharmacodynamic (PD) and pharmacokinetic (PK) profiles of $\mathbf{1 2 b}$ are shown in Table 3. PAN-04 is a human pancreatic xenograft tumor line derived from a clinical specimen established by the Central Institute for Experimental Animals (Kanagawa, Japan). This xenograft tumor significantly expressed stroma-derived Gli1 and cancer-derived Shh activity. The reduction of Glil $m$ RNA expression levels was measured as a PD marker in this model. Compound 12b showed potent activity in a Smo binding assay $\left(\mathrm{IC}_{50}: 41 \mathrm{nM}\right)$, favorable in vitro metabolic stability in both mouse and human microsomes, and favorable mouse PK profile. Consistent with the results of in vitro activities and ADME profiles, 12b strongly suppressed Gli1 $m$ RNA expression after a single cycle of dosing at $25 \mathrm{mg} / \mathrm{kg}$, twice daily (BID). 
Table 3. Activity in in vivo PD assay, properties and pharmacokinetic data of $\mathbf{1 2 b}$.

\begin{tabular}{|c|c|c|c|c|c|c|c|c|c|}
\hline \multirow{2}{*}{ cmpd } & \multirow{2}{*}{$\begin{array}{l}\text { Smo binding } \\
\text { (nM) }\end{array}$} & \multirow{2}{*}{$\begin{array}{l}\text { in vivo } \mathrm{PD} \\
\text { Gli1 } m \mathrm{RNA} \\
(\% \text { of ctrl })^{a}\end{array}$} & \multicolumn{2}{|c|}{$\begin{array}{c}\text { metabolic stability }^{b} \\
(\mu \mathrm{L} / \mathrm{min} / \mathrm{mg})\end{array}$} & \multicolumn{5}{|c|}{ Mouse $\mathrm{PK}^{c}$} \\
\hline & & & Mouse & Human & $\operatorname{Cmax}(\mu \mathrm{g} / \mathrm{mL})$ & Tmax (h) & MRT (h) & $\mathrm{AUC}(\mu \mathrm{gh} / \mathrm{mL})$ & $\mathrm{C}_{8 \mathrm{~h}}(\mathrm{~h})$ \\
\hline $12 \mathrm{~b}$ & 41 & 5 & 11 & $\mathrm{ND}^{d}$ & 2.65 & 1.00 & 2.99 & 12.1 & 0.604 \\
\hline
\end{tabular}

${ }^{a}$ Gli1 $m$ RNA expression at $25 \mathrm{mg} / \mathrm{kg}$ bid. The value is indicated the Gli1 $m$ RNA expression level compare to control. The compound $\mathbf{1 2 b}$ was dosed at $25 \mathrm{mg} / \mathrm{kg}$ bid.

${ }^{b}$ Hepatic microsome.

${ }^{c}$ Cassette dosing at $10 \mathrm{mg} / \mathrm{kg}$ po.

${ }^{d}$ Not detected. The compound did not reduce under metabolism test.

Compound 12b demonstrated marked suppression of Glil $m$ RNA in the PAN-04 model. This supported in vivo efficacy studies with compound 12b in a medulloblastoma allograft model generated from $\mathrm{Ptc}+/-\mathrm{p} 53-/-$ mice in which the $\mathrm{Hh}$ signaling pathway was constitutively activated. Oral administration of compound 12b for two weeks at $6.25 \mathrm{mg} / \mathrm{kg}$ BID resulted in virtually complete suppression of tumor growth $(T / C$ ratio $=3 \%$; Figure 8 , left) without notable body weight loss (Figure 8 , right). It was suggested that compound $\mathbf{1 2 b}$ might be effective in the treatment of cancers that are activated by $\mathrm{Hh}$ signaling in mice.
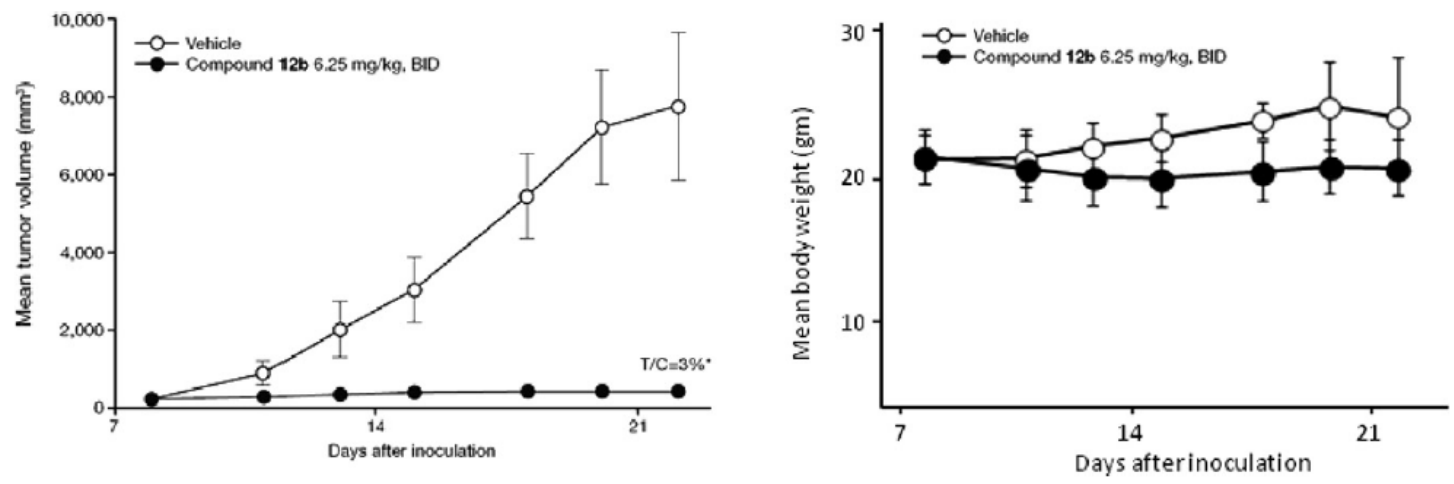

Figure 8. Antitumor activity (left) and body weight change (right) upon treatment with 12b in nude mice carrying Ptc+/- p53-/- medulloblastoma allograft tumors. ${ }^{a}$

${ }^{a}$ Compound 12b was administrated orally at a dose of $6.25 \mathrm{mg} / \mathrm{kg}$ BID for 14 days $(\bullet)$; vehicle controls (O). Each point represents the mean $\pm \mathrm{SD}$ of duplicate values. $* \mathrm{P}<0.025$ by a 1 -tailed Dunnett's test compared to controls.

\subsection{Conclusion}

In these studies, HTS to identify Hh signaling inhibitors resulted in a novel lead compound 1a, which possesses a thieno[3,2-c]quinoline-4-one core structure. The 
medicinal chemistry efforts, focusing on maintaining in vitro activity while significantly improving metabolic stability, led to pyrrolo[3,2-c]quinoline-4-one 12b with a characteristic side chain at the 2-position. Compound 12b showed suppression of Gli1 $m$ RNA expression and virtually complete growth suppression in the medulloblastoma allograft model. This in vivo efficacy encouraged to seek Hh signaling inhibitors that might be considered as candidates for clinical research in patients with cancers that are characterized by aberrant Hh signaling activity. 


\section{Chapter II}

\section{Discovery of TAK-441 as orally available candidate}

\subsection{Introduction}

In a previous chapter, the synthesis and biological activity of $\mathrm{N}$-(1-glycoloylpiperidin-4-yl)-3-methoxy-1-methyl-4-oxo-5-(2-oxo-2-phenylethyl)-4,5dihydro-1H-pyrrolo[3,2-c] quinoline-2-carboxamide 12b as a potent $\mathrm{Hh}$ signaling inhibitor were described. The phenacyl group at the 5-position is important for its potent in vitro activity, and the $N$-[1-(hydroxyacetyl)piperidinyl] amide side chain at the 2-position provided high metabolic stability in mouse and human. Moreover, the amide was effective substituent for the reduction of hERG inhibition, which is important in cardiac repolarization, based on the avoidance of tertiary amine structure.

Table 4. Activity, solubility and PK profile of compound $\mathbf{1 2 b}$.

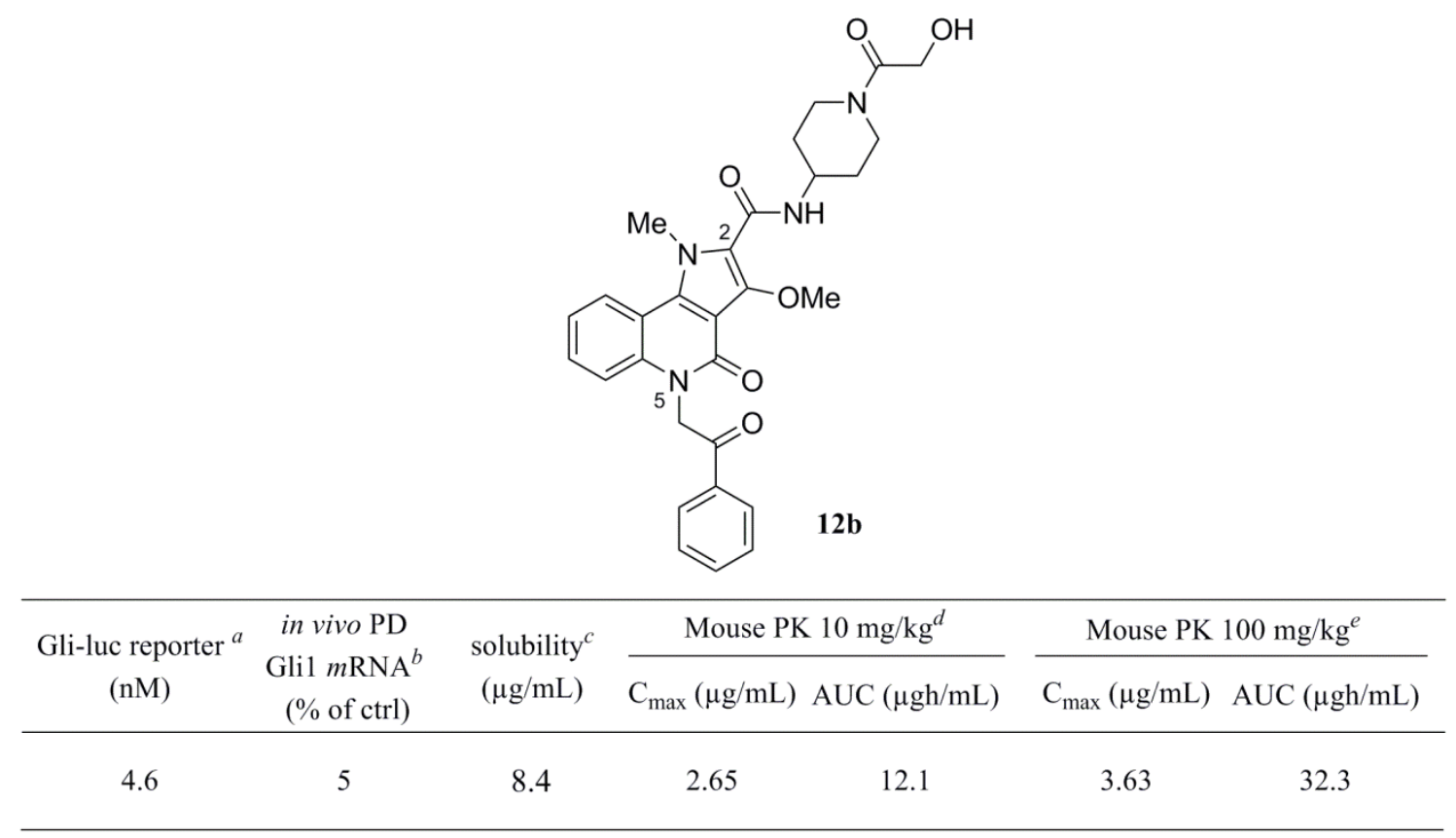

\footnotetext{
${ }^{a} \mathrm{IC}_{50}$ values are the mean of four measurements.

${ }^{b}$ The value is the Gli1 $m$ RNA expression level at $25 \mathrm{mg} / \mathrm{kg}$ BID of compound 12b compared to controls.

${ }^{c}$ Measured at pH 6.8 (Japanese Pharmacopoeia second fluid).

${ }^{d}$ Cassette dosing, $\mathrm{AUC}_{0-8 \mathrm{~h}}$

${ }^{e} \mathrm{BALB} / \mathrm{c}-\mathrm{nu} / \mathrm{nu}$ mice, $\mathrm{AUC}_{0-24 \mathrm{~h}}$
} 
Compound 12b exhibited potent suppression of tumor growth in in vivo experiments in a mouse medulloblastoma allograft model. However, the PK profile of 12b at high dose in mice $(100 \mathrm{mg} / \mathrm{kg})$ showed poor oral absorption that was not proportional to dose $\left(\mathrm{AUC}_{0-24 \mathrm{~h}} 32.3 \mu \mathrm{gh} / \mathrm{mL}\right.$; Table 4). Considering that this poor oral absorption could be attributed to low solubility $(8.4 \mu \mathrm{g} / \mathrm{mL}$ at $\mathrm{pH} 6.8)$, the author sought to improve the solubility while maintaining Hh pathway inhibitory activity as shown in Figure 9. In general, compounds with a tricyclic core show poor solubility and often low bioavailability. ${ }^{23}$ Thus, the benzene ring on pyrrolo[3,2-c]quinoline-4-one was removed in order to decrease planarity. In addition, it was speculated that the residual substituent at the 3-position was available for modification of the physicochemical properties. The investigations in chapter I demonstrated that substituents at the 2- and 5 -positions were fixed because they played important roles in potency and metabolic stability as mentioned above. Herein, the design and synthesis of a novel series of derivatives leading to the identification of clinical candidate are described.

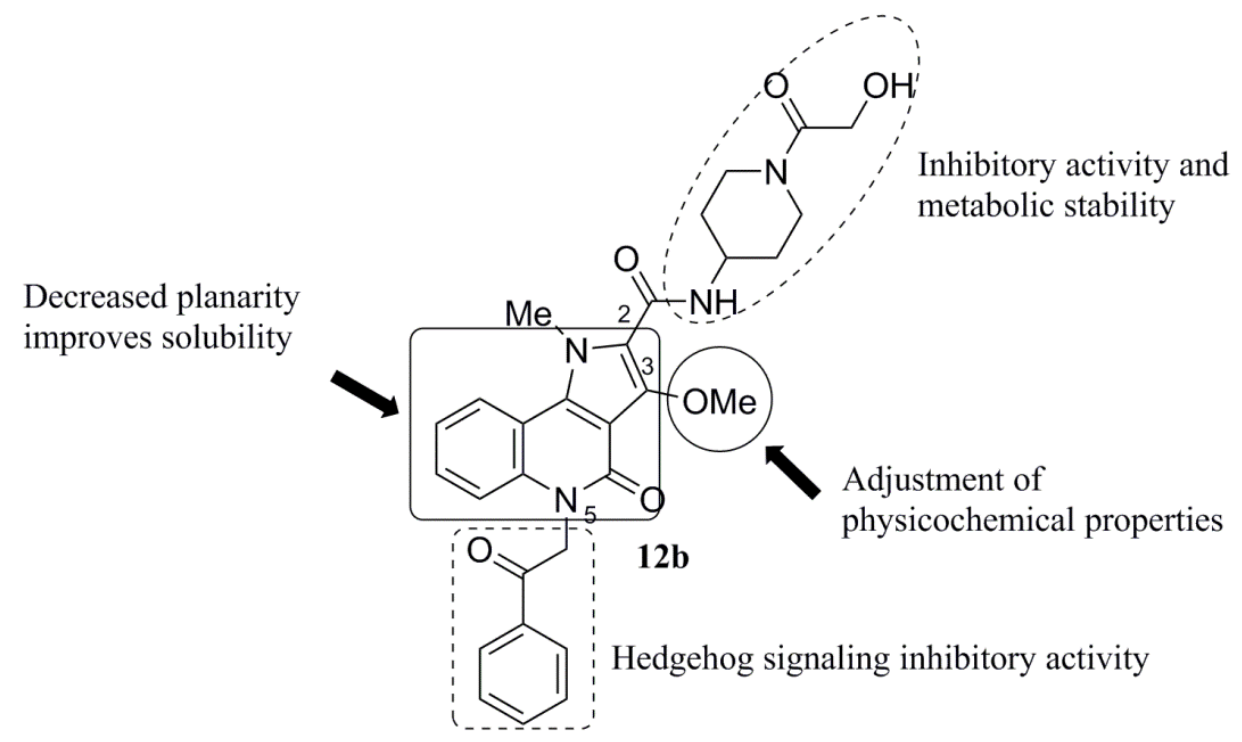

Figure 9. Compound design strategy for improving solubility and maintaining potency.

\subsection{Synthesis}

The removal of benzene ring from compound $\mathbf{1 2 b}$ was expected to reduce planarity. Retrosynthetic analysis (Figure 10) demonstrated that ketoesters bearing $\mathrm{R}^{6}$ and $\mathrm{R}^{7}$ substituents would allow investigation of replacements for the phenyl ring that was being removed. 


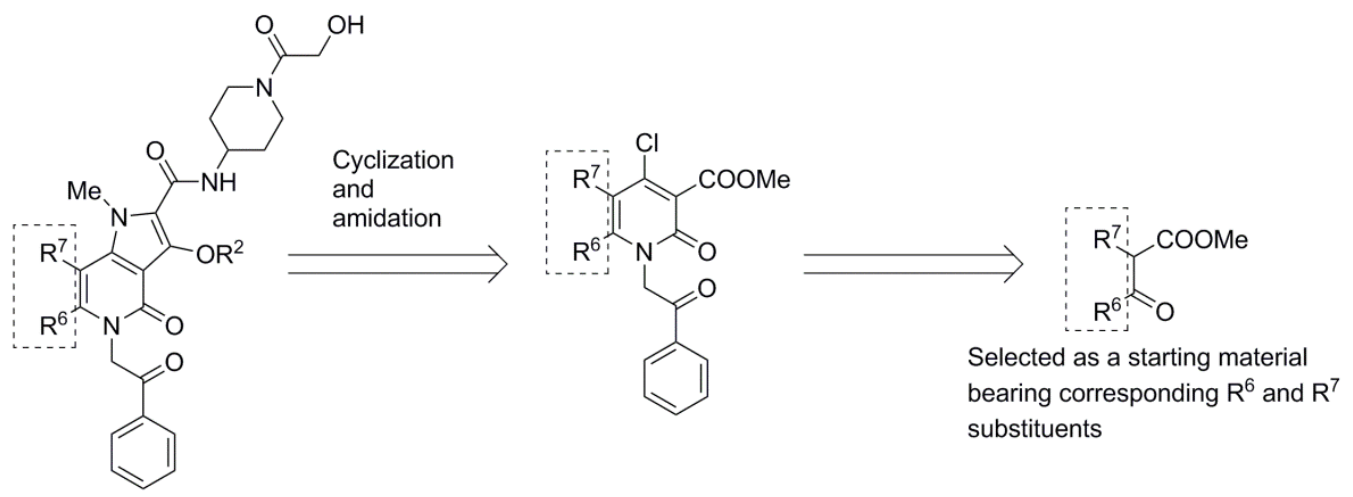

Figure 10. Synthetic strategy.

The general synthesis of the compounds in this study is outlined below. Pyridone 15, except for commercially available 15c, was prepared from 13. Ketoester 13 was converted to 14 by amination. Cyclization of 14 with diethyl malonate afforded 15 in $60-92 \%$ yield. Monochlorination of 15 was achieved using phosphoryl chloride in $17-60 \%$ yield. Alkylation of $\mathbf{1 6}$ with phenacyl bromide and potassium carbonate proceeded in low yield (7-23\%) because of the production of $O$-phenacylated compound as a major product. Substitution and cyclization of $\mathbf{1 7}$ was conducted with sarcosine ethyl ester hydrochloride under basic conditions ${ }^{24}$ to obtain pyrrolo[3,2-c]pyridine 18. The hydroxyl group at the 3-position of $\mathbf{1 8}$ was treated with various alkylating reagents to afford corresponding alkoxy derivatives 19a-e, 19i, and 19j. Ethyl derivative 19h was prepared by treatment of 18a with trifluoromethanesulfonic anhydride and afforded triflate 19f. Following Stille coupling of the obtained triflate 19f with vinyltributyltin, ethenyl derivative $19 \mathrm{~g}$ was treated with palladium on carbon under hydrogen atmosphere to give the 3-ethyl derivative 19h. Finally, saponification of 19 afforded the corresponding carboxylic acid 20 in $23-99 \%$ yield (Scheme 3 ). 
Scheme 3. Synthesis of carboxylic acid 20.
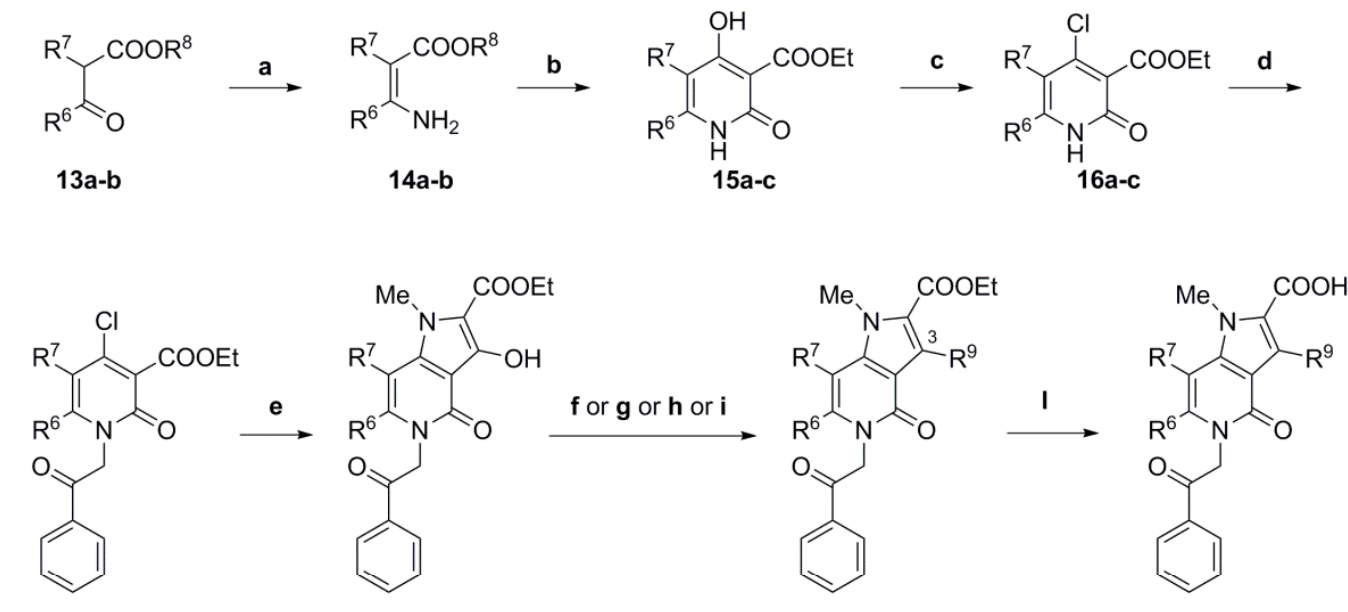

$18 \mathrm{a}-\mathrm{c}$

\begin{tabular}{ccccc}
\hline cmpds & $\mathrm{R}^{6}$ & $\mathrm{R}^{7}$ & $\mathrm{R}^{8}$ & yield \\
\hline 13a 14a & $\mathrm{Et}$ & $\mathrm{H}$ & $\mathrm{Me}$ & 92 \\
13b 14b & $-\left(\mathrm{CH}_{2}\right)_{4^{-}}$ & $\mathrm{Et}$ & 60
\end{tabular}

\begin{tabular}{llll}
$13 \mathbf{b} 14 \mathbf{b}$ & $-\left(\mathrm{CH}_{2}\right)_{4}-$ & Et & 60 \\
\hline
\end{tabular}

\begin{tabular}{llcccccc}
\hline \multirow{2}{*}{ cmpds } & \multirow{2}{*}{$\mathrm{R}^{6}$} & \multicolumn{5}{c}{$\mathrm{R}^{7}$} & \multicolumn{4}{c}{ yield } \\
\cline { 4 - 7 } & & & $\mathbf{1 4}$ to $\mathbf{1 5} \mathbf{1 5}$ to $\mathbf{1 6 \mathbf { 1 6 }}$ to $\mathbf{1 7 \mathbf { 1 7 }}$ to $\mathbf{1 8}$ \\
\hline $\mathbf{1 5 - 1 8 a}$ & Et & $\mathrm{H}$ & 46 & 60 & 7 & 74 \\
$\mathbf{1 5 - 1 8 b}$ & $-\left(\mathrm{CH}_{2}\right)_{4^{-}}$ & 58 & 17 & 16 & - \\
$\mathbf{1 5 - 1 8 c}$ & $\mathrm{Me}$ & $\mathrm{H}$ & & 44 & 23 & 68
\end{tabular}

\begin{tabular}{|c|c|c|c|c|c|c|c|c|c|}
\hline & \multicolumn{4}{|c|}{ 19a-j } & \multicolumn{5}{|c|}{$20 a-j$} \\
\hline cmpds & $\mathrm{R}^{6}$ & $\mathrm{R}^{7}$ & $\mathrm{R}^{9}$ & yield & cmpds & $\mathrm{R}^{6}$ & $\mathrm{R}^{7}$ & $\mathrm{R}^{9}$ & yield \\
\hline 19a & Et & $\mathrm{H}$ & OEt & 82 & $20 \mathrm{a}$ & Et & $\mathrm{H}$ & OEt & 89 \\
\hline $19 b$ & Et & $\mathrm{H}$ & $\mathrm{OCH}_{2} \mathrm{CH}_{2} \mathrm{~F}$ & 77 & $20 \mathrm{~b}$ & Et & $\mathrm{H}$ & $\mathrm{OCH}_{2} \mathrm{CH}_{2} \mathrm{~F}$ & 56 \\
\hline $19 \mathrm{c}$ & Et & $\mathrm{H}$ & $\mathrm{OCH}_{2} \mathrm{CHF}_{2}$ & 77 & $20 \mathrm{c}$ & Et & $\mathrm{H}$ & $\mathrm{OCH}_{2} \mathrm{CHF}_{2}$ & 83 \\
\hline 19d & Et & $\mathrm{H}$ & $\mathrm{OCH}_{2} \mathrm{CF}_{3}$ & 86 & $20 d$ & Et & $\mathrm{H}$ & $\mathrm{OCH}_{2} \mathrm{CF}_{3}$ & 93 \\
\hline $19 \mathrm{e}$ & Et & $\mathrm{H}$ & $\mathrm{OMe}$ & 23 & $20 \mathrm{e}$ & Et & $\mathrm{H}$ & $\mathrm{OMe}$ & 79 \\
\hline 19f & Et & $\mathrm{H}$ & OTf & 59 & $20 \mathrm{~h}$ & Et & $\mathrm{H}$ & Et & 99 \\
\hline$\Rightarrow 19 \mathrm{~g}$ & Et & $\mathrm{H}$ & ethenyl & $72^{1)}$ & $20 \mathrm{i}$ & $-(\mathrm{CH}$ & $4^{-}$ & $\mathrm{OMe}$ & 23 \\
\hline$-19 h$ & Et & $\mathrm{H}$ & $\mathrm{Et}$ & $100^{2)}$ & $20 \mathrm{j}$ & $\mathrm{Me}$ & $\mathrm{H}$ & $\mathrm{OMe}$ & 89 \\
\hline $19 \mathrm{i}$ & $-\left(\mathrm{CH}_{2}\right)$ & & $\mathrm{OMe}$ & $11^{3)}$ & & & & & \\
\hline $19 \mathrm{j}$ & $\mathrm{Me}$ & $\mathrm{H}$ & $\mathrm{OMe}$ & 26 & & & & & \\
\hline
\end{tabular}

Reagents and conditions: (a) $\mathrm{NH}_{4} \mathrm{OAc}, \mathrm{MeOH}$, rt; (b) diethyl malonate, $\mathrm{NaOEt}$, EtOH, xylene, $120{ }^{\circ} \mathrm{C}$, then $150{ }^{\circ} \mathrm{C}$; (c) $\mathrm{POCl}_{3}$ for $\mathbf{1 6 a , b}$ or $\mathrm{POCl}_{3}, \mathrm{BnEt}_{3} \mathrm{NCl}, \mathrm{MeCN}, 40{ }^{\circ} \mathrm{C}$, then reflux for $\mathbf{1 6 c}$; (d) $\mathrm{PhCOCH}_{2} \mathrm{Br}, \mathrm{K}_{2} \mathrm{CO}_{3}$, DMF, rt for 17a,c or $\mathrm{PhCOCH} \mathrm{CH}_{2} \mathrm{Br}$, NaH, DMA, rt for $\mathbf{1 7 b}$; (e) $\mathrm{MeNHCH}_{2} \mathrm{COOEt} \cdot \mathrm{HCl}, \mathrm{Et}_{3} \mathrm{~N}$, EtOH, reflux; (f) $\mathrm{R}$ 'X, DBU, DMF, rt for 19b $\left(\mathrm{R}^{\prime}=\mathrm{CH}_{2} \mathrm{CH}_{2} \mathrm{~F}\right), \mathbf{1 9 e}, \mathbf{j}$ $\left(\mathrm{R}^{\prime}=\mathrm{Me}\right)$; (g) $\mathrm{R}_{2} \mathrm{SO}_{4}, \mathrm{~K}_{2} \mathrm{CO}_{3}$, acetone, reflux for 19a $\left(\mathrm{R}^{\prime}=\mathrm{Et}\right)$, 19i $\left(\mathrm{R}^{\prime}=\mathrm{Me}\right)$; (h) R'OTf, $\mathrm{Cs}_{2} \mathrm{CO}_{3}$, DMF, rt for 19c $\left(\mathrm{R}^{\prime}=\mathrm{CH}_{2} \mathrm{CHF}_{2}\right)$, 19d $\left(\mathrm{R}^{\prime}=\mathrm{CH}_{2} \mathrm{CF}_{3}\right)$; (i) $\mathrm{Tf}_{2} \mathrm{O}$, pyridine, $60{ }^{\circ} \mathrm{C}$ for 19f; (j) vinyltributyltin, $\mathrm{Pd}\left(\mathrm{PPh}_{3}\right)_{4}, \mathrm{DMF}, 100{ }^{\circ} \mathrm{C}$; (k) Pd/C, $\mathrm{H}_{2}, \mathrm{THF} / \mathrm{MeOH}$, rt; (l) $\mathrm{NaOH}, \mathrm{EtOH}, \mathrm{H}_{2} \mathrm{O}, 60^{\circ} \mathrm{C}$.

Amidation of carboxylic acid 20 is shown in Scheme 4. Compounds 22e and 22j were synthesized from corresponding carboxylic acids $20 \mathbf{e}$ and $20 \mathbf{j}$ by stepwise acylation. Compounds 22a-d, 22h, and 22i were obtained by condensation of corresponding carboxylic acid $\mathbf{2 0}$ with amine $\mathbf{2 4}$ directly. The requisite $\mathbf{2 4}$ was prepared from 4-Boc-aminopiperidine (23) in three steps: acylation with acetoxyacetyl chloride, followed by removal of the acetyl and tert-butoxycarbonyl groups in $80 \%$ yield . 


\section{Scheme 4.}

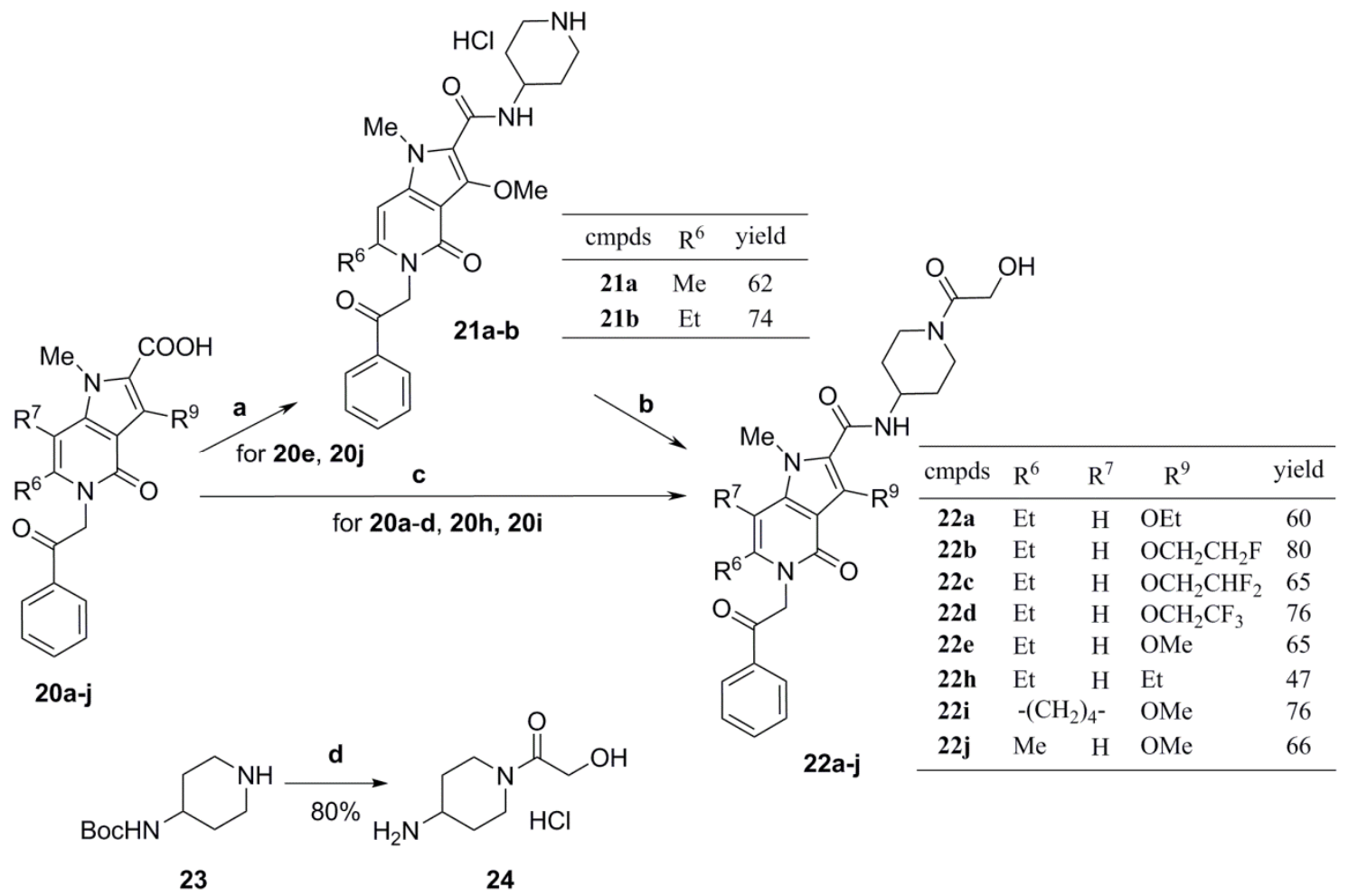

Reagents and conditions : (a) (1) 4-amino-1-Boc-piperidine, EDC, HOBt, DMF, rt, (2) 4M HCl in AcOEt, AcOEt, rt; (b) (1) $\mathrm{ClCOCH}_{2} \mathrm{OAc}, \mathrm{Et}_{3} \mathrm{~N}$, THF, rt, (2) $\mathrm{NaOH}, \mathrm{EtOH}, \mathrm{H}_{2} \mathrm{O}$, rt for 22e, 22j; (c) 24, EDC, $\mathrm{HOBt}$, DMF, rt for 22a-d, 22h, 22i; (d) (1) $\mathrm{ClCOCH}_{2} \mathrm{OAc}, \mathrm{Et}_{3} \mathrm{~N}$, THF, $0{ }^{\circ} \mathrm{C}$; (2) $8 \mathrm{M} \mathrm{NaOH}, \mathrm{EtOH}, \mathrm{H}_{2} \mathrm{O}$, rt; (3) $4 \mathrm{M} \mathrm{HCl}$ in AcOEt, AcOEt, rt.

\subsection{Results and discussion}

\subsubsection{Biological data for hedgehog, and SAR study}

In vitro activities of compounds 22a-j were evaluated using luciferase reporter activities in NIH3T3 cells carrying a stably-transfected Gli-reporter construct, designated the Gli-luc reporter cell line. First, modification of the benzene ring to cyclohexane in the core structure was examined. In the Gli-luc reporter assay, cyclohexene 22i showed an approximately 20-fold decreased activity compared with 12d (Table 5). This result implied that a substituent with specific size and shape would be required for maintaining the potent inhibition of Gli-luc reporter activity. Downsizing the cyclohexene ring to a monomethyl group $\left(\mathrm{R}^{6}\right)$ was effective in maintaining activity (22j vs $\mathbf{2 2} \mathbf{i}$ ). In addition, solubility of $\mathbf{2 2} \mathbf{j}$ was improved compared with that of $\mathbf{1 2 d}$, as expected. Introduction of an ethyl group at the 6-position resulted in further enhancement of Hh inhibitory activity without loss of solubility (22e vs 22j). Among the compounds listed in Table 5, the 6-ethyl derivative 22e which had potent activity in 
the Gli-luc reporter assay and good solubility was selected for further investigation.

Table 5. Modification of the core ring.

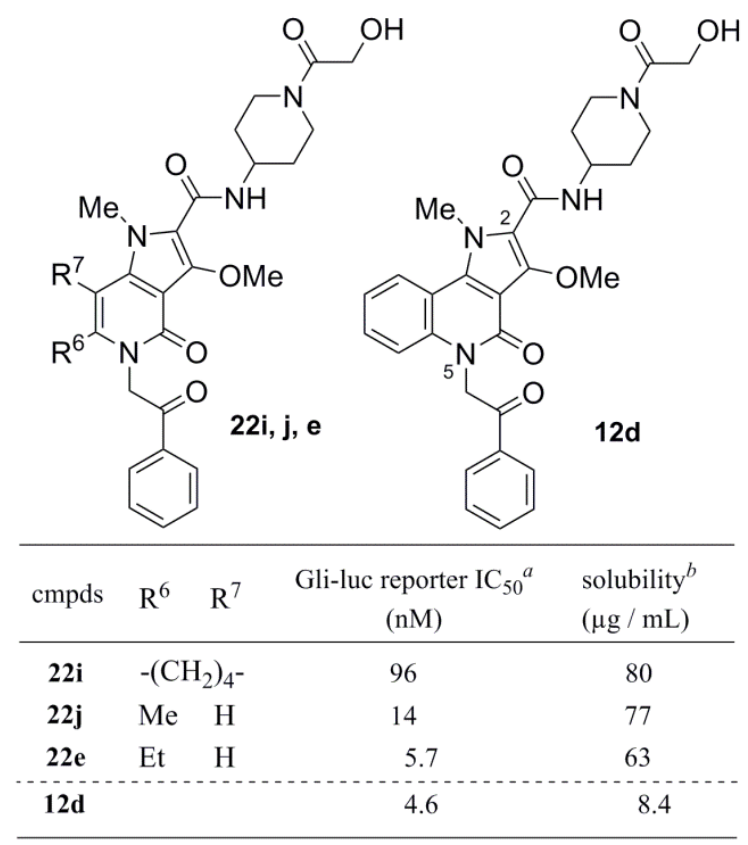

${ }^{a} \mathrm{IC}_{50}$ values are the mean of four measurements.

${ }^{b}$ Measured at pH 6.8 (Japanese Pharmacopoeia second fluid).

Compound 22e was conducted in vivo PD study at $25 \mathrm{mg} / \mathrm{kg}$, BID, but the efficacy was weak. It was considered the solubility of the compound 22e was insufficient to show good efficacy at higher dose, thus the chemical modification for further improvement of solubility was continued. Thus, the synthetic efforts next focused on modification of substituents at the 3-position (Table 6). Exchange of the methoxy group in 22e to an ethyl group significantly decreased activity (22h vs $22 \mathbf{e}$ ). This result suggested that the oxygen atom in the 3-methoxy group in 22e plays an important role in activity. In general, fluorination of alkyl substituents is known to impact the physicochemical profile by changing lipophilic and electronic factors. ${ }^{25}$ Therefore, the effect of fluorination on solubility and potency was investigated by using the 3-ethoxy derivative 22a as a standard compound with good activity and solubility.

Both 2-fluoroethoxy (22b) and 2,2-difluoroethoxy (22c) groups effectively increased solubility, but exposure (AUC) of these compounds in mice following oral dosing was decreased compared with that of 22a. On the other hand, 2,2,2-trifluoroethoxy derivative 22d exhibited favorable exposure compared to 22a and 22e. Furthermore, the oral absorption of $\mathbf{2 2 d}$ was better than that of $\mathbf{1 2} \mathbf{b}$, suggesting 
that the improvement of solubility was contributed to good PK profile at higher dose (Table 7). Thus, 22d was selected as a compound for further investigation.

Table 6. Optimization of pyrroro[3,2-c]pyridine at the 3-position.

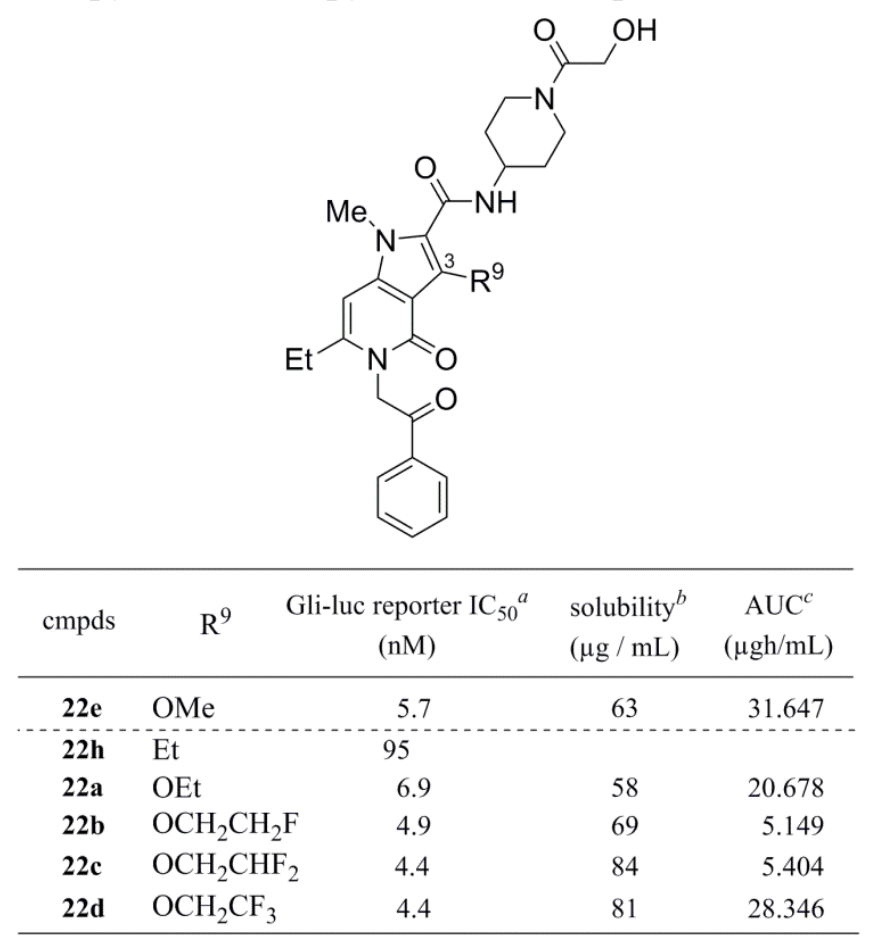

${ }^{a} \mathrm{IC}_{50}$ values are the mean of four measurements.

${ }^{b}$ Measured at pH 6.8 (Japanese Pharmacopoeia second fluid).

${ }^{c}$ Cassette dosing at $10 \mathrm{mg} / \mathrm{kg}$, po in mice. AUC means area under the plasma concentration versus time curve from 0 to 8 hours.

Table 7. Pharmacokinetic data of $\mathbf{1 2 b}$ and $\mathbf{2 2 d}$.

\begin{tabular}{cccccc}
\hline \multirow{2}{*}{ cmpd } & \multicolumn{2}{c}{ Mouse PK $10 \mathrm{mg} / \mathrm{kg}^{a}$} & & \multicolumn{2}{c}{ Mouse PK $100 \mathrm{mg} / \mathrm{kg}^{b}$} \\
\cline { 2 - 3 } \cline { 5 - 6 } & $\mathrm{C}_{\max }(\mu \mathrm{g} / \mathrm{mL})$ & $\mathrm{AUC}(\mu \mathrm{gh} / \mathrm{mL})$ & & $\mathrm{C}_{\max }(\mu \mathrm{g} / \mathrm{mL})$ & $\mathrm{AUC}(\mu \mathrm{gh} / \mathrm{mL})$ \\
\hline 12b & 2.65 & 12.1 & & 3.63 & 32.3 \\
22d & 5.63 & 28.3 & & 21.5 & 206 \\
\hline
\end{tabular}

${ }^{a}$ Cassette dosing, $\mathrm{AUC}_{0-8 \mathrm{~h}}$

${ }^{b} \mathrm{BALB} / \mathrm{c}-\mathrm{nu} / \mathrm{nu}$ mice, $\mathrm{AUC}_{0-24 \mathrm{~h}}$ 


\subsubsection{X-ray single crystal structure analysis of 22d}

As mentioned above, the oxygen atom in the alkoxy group at the 3-position was important for inhibitory activity. An X-ray structural analysis of 22d suggested an explanation for this finding (Figure 11). An intramolecular hydrogen bond interaction was observed between the oxygen atom in the 2,2,2-trifluoroethoxy group and the amide hydrogen atom at the $\mathrm{C} 2$ side chain. This conformation would not be favored in the C3-ethyl derivative. It was speculated that the oxygen atom would be necessary for hydrogen bond formation with the amide, thereby stabilizing the position of the side chain.

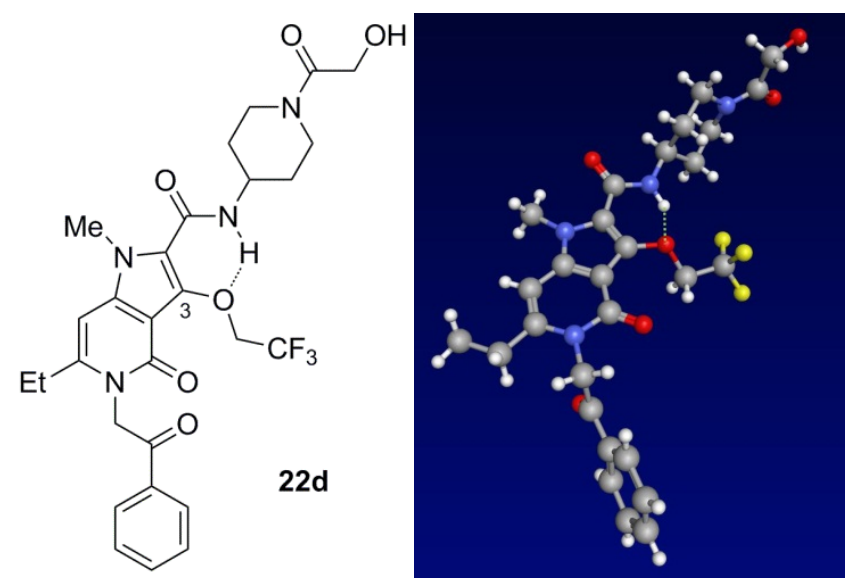

Figure 11. X-ray single crystal structure of compound 22d. ${ }^{a}$

${ }^{a}$ The figure was described based on X-ray structural analysis data using MOE Software. Molecular Operating Environment (MOE version 2010.10); Chemical Computing Group, Inc.: Montreal, Quebec, Canada; http://www.chemcomp.com.

\subsubsection{In vivo study of $22 \mathrm{~d}$}

The in vivo efficacy of 22d was evaluated by using a Ptc1+/- p53-/medulloblastoma allograft model in mice in which the Hh pathway was activated. Plasma and tumor concentrations of 11d after a single oral dose are shown in Figure 12 indicating good tumor permeability and dose linearity. Repeated oral administration of compound 22d (QD, 14 days) resulted in moderate antitumor activity with a $T / C$ value of $46 \%$ at a dose of $1 \mathrm{mg} / \mathrm{kg}$ (Figure 13); complete growth inhibition was observed at 25 $\mathrm{mg} / \mathrm{kg}(T / C=1 \%)$ without excessive accumulation. These data suggest that improved solubility resulted in a dose-dependent PK profile for compound 22d. 

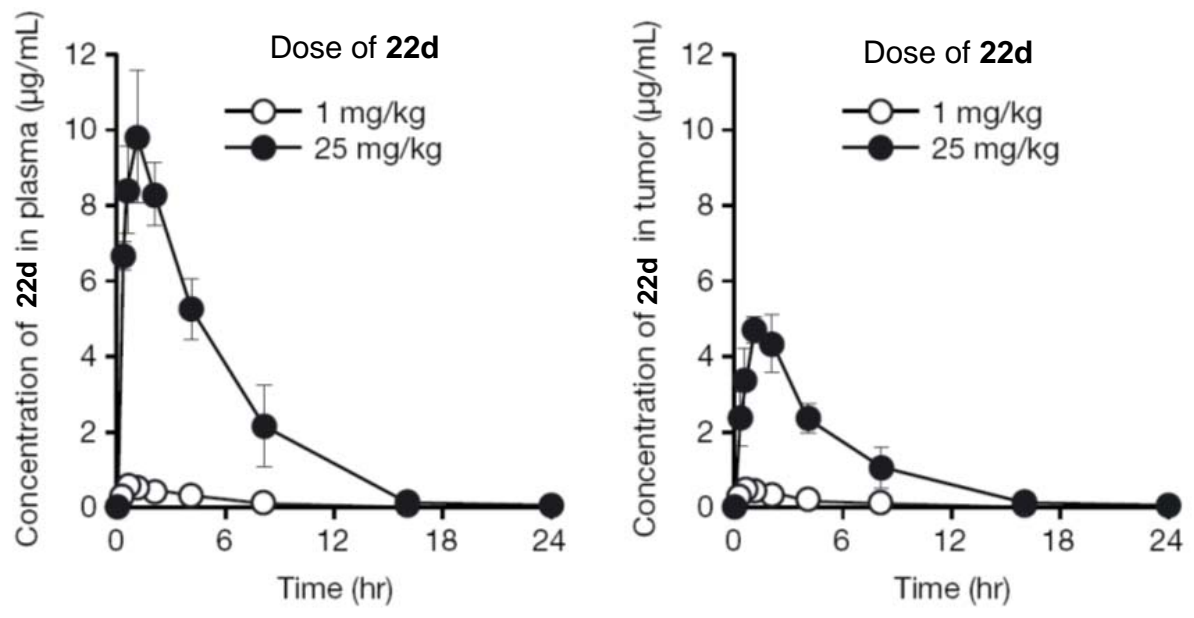

\begin{tabular}{cccccc}
\hline & \multicolumn{2}{c}{ Plasma } & & \multicolumn{2}{c}{ Tumor } \\
\cline { 2 - 3 } \cline { 5 - 6 } \cline { 5 - 6 } & $\mathrm{C}_{\max }(\mu \mathrm{g} / \mathrm{mL})$ & $\mathrm{AUC}_{0-24 \mathrm{~h}}(\mu \mathrm{gh} / \mathrm{mL})$ & & $\mathrm{C}_{\max }(\mu \mathrm{g} / \mathrm{mL})$ & $\mathrm{AUC}_{0-24 \mathrm{~h}}(\mu \mathrm{gh} / \mathrm{mL})$ \\
\hline $1 \mathrm{mg} / \mathrm{kg}$ & 0.659 & 3.36 & & 0.244 & 1.30 \\
$25 \mathrm{mg} / \mathrm{kg}$ & 9.87 & 54.3 & & 4.65 & 25.3 \\
\hline
\end{tabular}

Figure 12. Concentrations of compound 22d in the plasma and tumor after oral administration at doses of 1 and $25 \mathrm{mg} / \mathrm{kg}$ in medulloblastoma allografted mice. ${ }^{a}$

${ }^{a}$ Mean \pm standard deviation, $\mathrm{SD}(\mathrm{n}=3)$
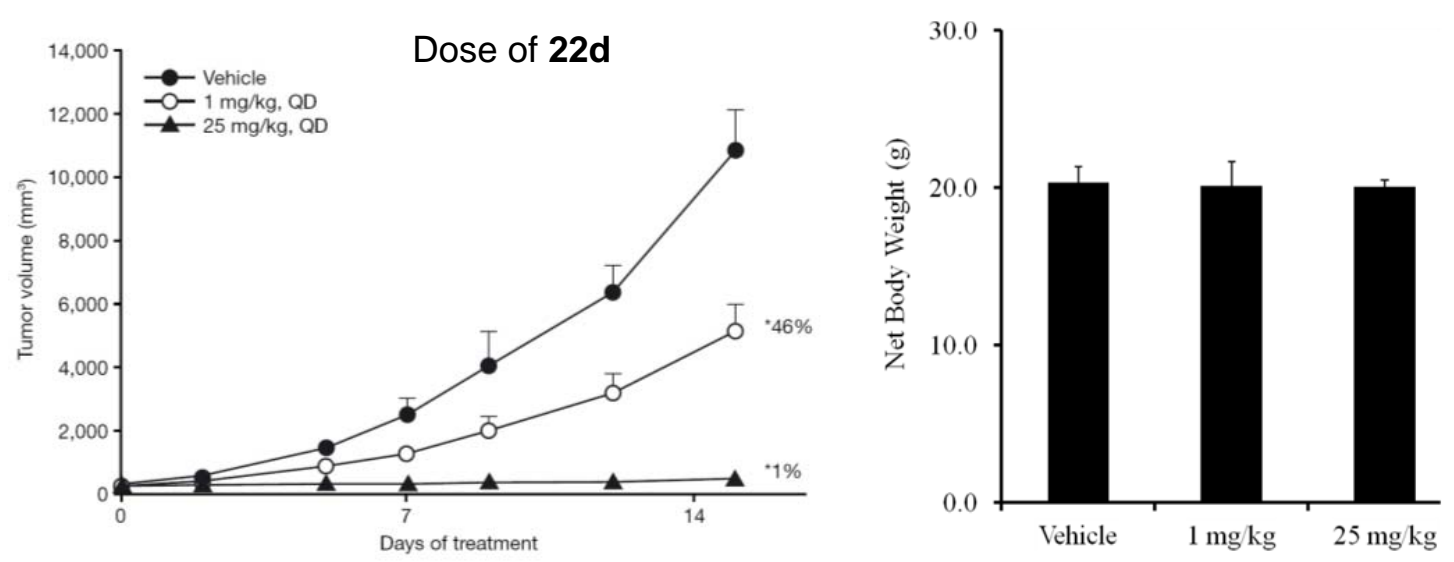

Figure 13. Efficacy of compound 22d in medulloblastoma in a Ptc1+/- p53-/- mouse allograft model (left) and body weight after 14 days, QD (right).

Oral administration of 22d in mice once daily (QD) for 14 days at $1 \mathrm{mg} / \mathrm{kg}(\mathrm{O})$ or $25 \mathrm{mg} / \mathrm{kg}(\mathbf{\Delta})$ compared with vehicle-treated animals $(\bullet)$. Data are shown as mean $\pm \mathrm{SD}(\mathrm{n}=5)$. Antitumor effects were expressed as the ratio of treatment vs control (T/C, \%) which was calculated by comparison of the mean change in tumor volume over the treatment period for the control and treated groups. ${ }^{*} P \leq 0.025$ by a 1-tailed Shirley-Williams test compared to vehicle control. 


\subsubsection{Pharmacokinetic data of $22 \mathrm{~d}$ in other animals}

The PK profiles of 22d in other species are shown in Table 8. Compound 22d showed favorable oral bioavailability $(\mathrm{F})$, which was $32 \%$ in rats and $90 \%$ in dogs. Moreover, low drug clearance (CL) and high AUC were observed in dogs. These results suggested that compound 22d is able to achieve sufficient exposure following oral administration in rats and dogs to enable appropriate toxicological studies.

Table 8 Pharmacokinetic profile ${ }^{a}$ in rats and dogs

\begin{tabular}{lccccc}
\hline $\begin{array}{c}V_{\text {ss }} \\
(\mathrm{mL} / \mathrm{kg})\end{array}$ & $\begin{array}{c}\mathrm{CL} \\
(\mathrm{mL} / \mathrm{h} / \mathrm{kg})\end{array}$ & $\begin{array}{c}\mathrm{AUC} \text { 0-24h,iv } \\
(\mathrm{ng} \bullet \mathrm{h} / \mathrm{mL})\end{array}$ & $\begin{array}{c}\mathrm{AUC}_{0-24 \mathrm{~h}, \mathrm{po}} \\
(\mathrm{ng} \bullet \mathrm{h} / \mathrm{mL})\end{array}$ & $\mathrm{F} \mathrm{( \% )}$ \\
\hline $\mathrm{Rat}^{b}$ & $681.6 \pm 81.6$ & $397.9 \pm 10.1$ & $2532.3 \pm 69.1$ & $8031.8 \pm 1218.6$ & 31.7 \\
$\mathrm{Dog}^{c}$ & $2181.3 \pm 82.8$ & $161.3 \pm 35.6$ & $5101.5 \pm 685.5$ & $45405.6 \pm 5812.0$ & $90.3 \pm 8.8$ \\
\hline
\end{tabular}

${ }^{a}$ Dose: iv, $1 \mathrm{mg} / \mathrm{kg} ;$ po, $10 \mathrm{mg} / \mathrm{kg}$

${ }^{b}$ Each value except for bioavailabilty (F\%) represents the mean $\pm \mathrm{SD}$ of three non-fasted animals. The $\mathrm{F}$ value is calculated from mean values of $\mathrm{AUC}_{0-24 \mathrm{~h}}$ after oral and intravenous administration.

${ }^{c}$ Each value represents the mean $\pm \mathrm{SD}$ of four fed animals. The $\mathrm{F}$ value is calculated from the individual value of $\mathrm{AUC}_{0-24 \mathrm{~h}}$ after oral and intravenous administration for the same animal.

\subsection{Conclusion}

With the aim of improving solubility, chemical modification of the first developed compound 12b was examined. Decreasing the planarity by reducing the number of aromatic rings led to the identification of the novel pyrrolo[3,2-c]pyridine-4-one derivative $\mathbf{2 2} \mathbf{j}$ which had good solubility. Further optimization of the 3-alkoxy group resulted in discovery of 22d with good physicochemical profiles and potent activity. Compound 22d exhibited strong antitumor activity in an in vivo study in Ptc1+/- p53-/mice bearing medulloblastoma allografts; improved solubility of compound 22d enabled dose-dependent plasma and tumor concentrations to be achieved in this model. 


\section{Chapter III}

\section{Synthesis and evaluation of hedgehog signaling inhibitor with novel core system}

\subsection{Introduction}

In previous chapters, the modification of core ring and substituent at 3-position of pyrrole ring for improvement of solubility were discussed. In the results, 6-ethyl- $N$-(1-glycoloylpiperidin-4-yl)-1-methyl-4-oxo-5-(2-oxo-2-phenylethyl)-3-(2,2,2 -trifluoroethoxy)-4,5-dihydro-1H-pyrrolo[3,2-c]pyridine-2-carboxamide

(TAK-441) was discovered. However, it was still unclear that exact role of the core skeleton including substituents at the 4- and 5-positions. Thus, further modification of central core was evaluated to confirm these properties and discovered new potent $\mathrm{Hh}$ signaling inhibitors with novel skeletons compared to that of 22d.

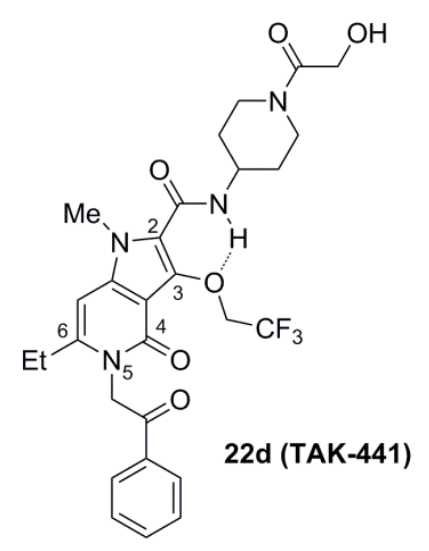

Figure 14. Chemical structure of 22d (TAK-441).

The substituents on the $N$-methyl pyrrole ring of 22d were essential for potent inhibitory activity because of the interaction by internal hydrogen bond between 2-amide NH and oxygen of 3-(2,2,2-trifluoro)ethoxy group. Thus this upper part was fixed, and the following modification was focused on the lower part of core ring, especially six-membered rings. Besides novel core ring modification, the effect of 4- or 5 -substituents to in vitro inhibitory activity was evaluated. In this chapter, the syntheses and SAR of novel hedgehog signaling inhibitors with multi-substituted bicyclic core rings are described (Figure 15). 

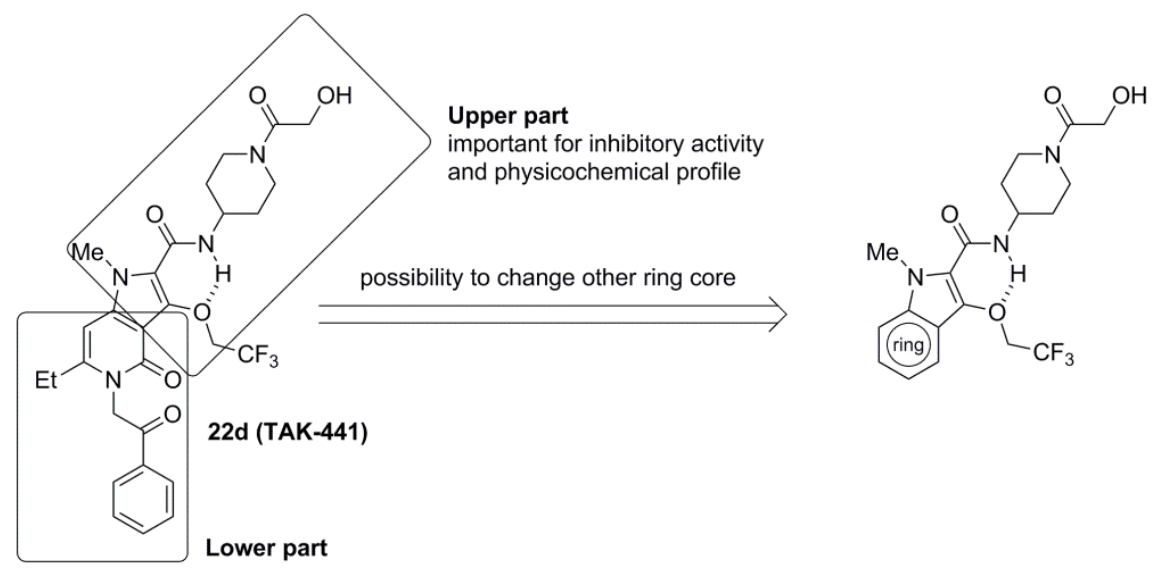

Figure 15. Change to novel core ring in 22d.

\subsection{Synthesis}

As mentioned, the intramolecular hydrogen bond formed between (2,2,2-trifluoro)ethoxy group at 3-position and $N$-[1-(hydroxyacetyl)piperidinyl] amide at the 2-position on $\mathrm{N}$-methyl pyrrole ring was important for potent in vitro activity. Figure 16 illustrates the retrosynthetic analysis to access novel bicyclic cores with these two moieties. To construct the unique bicyclic core of 25, it was necessary to synthesize intermediate 27. It was considered the Dieckmann condensation would be promising because the important substituents as mentioned before could be introduced in the desired position. Therefore, $o$-halo arylcarboxylic acid ester 29 was selected for a key intermediate which was converted to di-ester 28 by addition of sarcosine ester unit. ${ }^{24}$ This strategy could be utilized for the synthesis of various useful core rings. The syntheses for five types of carboxylic acid $\mathbf{2 8}$ are detailed in the next section.

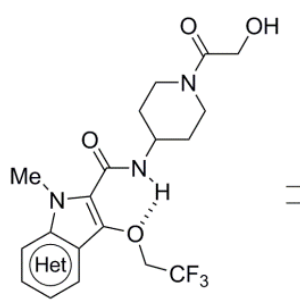

25

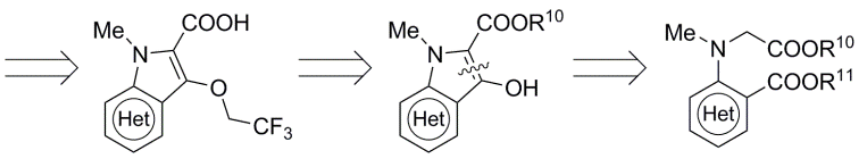

26
27

simple and effective construction of pyrrole unit using Dieckmann condensation

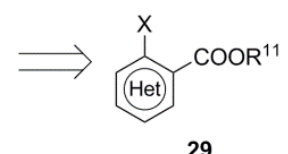

29

key intermediate in variety of novel ring core

Figure 16. Retrosynthetic analysis of novel core.

The synthesis of pyrrolo[2,3- $d$ ]pyrimidine 26a is shown in Scheme 5. Addition of propionitrile 30 with ammonia in acidic condition provided amidine hydrochloride $\mathbf{3 1}$, followed by cyclization with diethyl malonate to afford 32 in $67 \%$ yield. The 
preparation of a key intermediate 29a was conducted by stepwise conversion; introduction of formyl group, oxidation to carboxylic acid and esterification, then chlorination. After addition of sarcosine ethyl ester hydrochloride, subsequent Dieckmann condensation provided the bicyclic compound 27a in $91 \%$ yield. The 3-hydroxyl group of 27a was treated with (2,2,2-trifluoro)ethyl triflate to afford 33. The stepwise saponification of chloropyridine and ethoxycarbonyl moieties gave carboxylic acid 26a.

Scheme 5. Synthesis of pyrrolo[2,3- $d]$ pyrimidine derivative 26a.
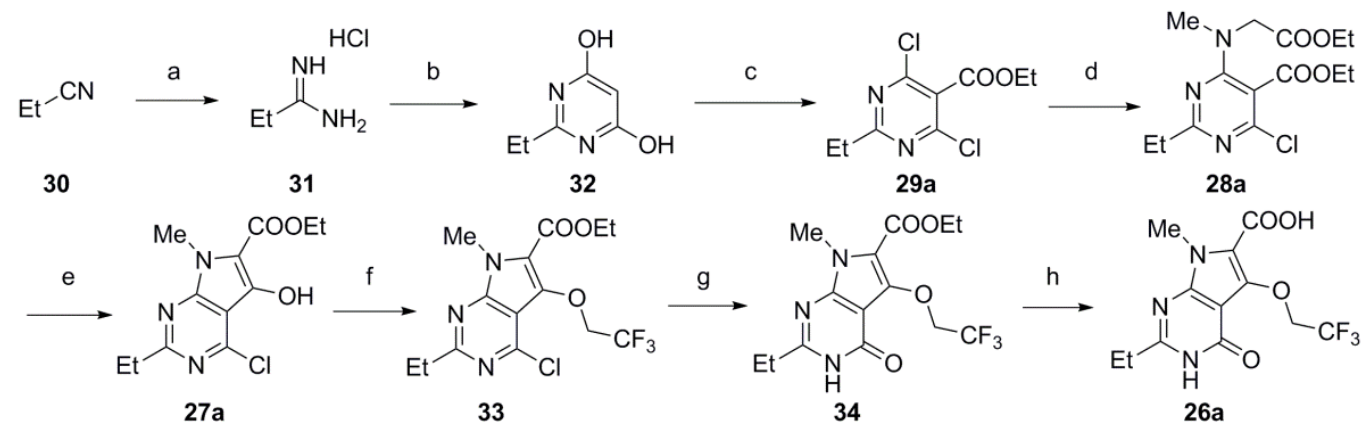

Reagents and conditions : (a) (1) $\mathrm{HCl}, \mathrm{EtOH}$; (2) $\mathrm{NH}_{3}, \mathrm{MeOH}, 70 \%$; (b) diethyl malonate, $\mathrm{NaOMe}$, $\mathrm{MeOH}, 67 \%$; (c) (1) DMF, $\mathrm{POCl}_{3}, 0{ }^{\circ} \mathrm{C}$ to reflux, $73 \%$; (2) $\mathrm{NaClO}_{2}$, sulfamic acid, tert- $\mathrm{BuOH} / \mathrm{H}_{2} \mathrm{O}$; (3) $(\mathrm{COCl})_{2}, \mathrm{DMF}$, THF; (4) $\mathrm{Et}_{3} \mathrm{~N}$, EtOH, 53\%; (d) $\mathrm{MeNHCH}_{2} \mathrm{COOEt} \cdot \mathrm{HCl}, \mathrm{Et}_{3} \mathrm{~N}, \mathrm{THF}, 99 \%$; (e) NaOEt, EtOH, 91\%; (f) $\mathrm{CF}_{3} \mathrm{CH}_{2} \mathrm{OTf}, \mathrm{Cs}_{2} \mathrm{CO}_{3}$, DMF, 91\%; (g) AcONa, AcOH, reflux, 96\%; (h) NaOH, EtOH, 60 ${ }^{\circ} \mathrm{C}, 79 \%$.

In the previous chapter, the synthesis of 22d using an intermediate with requisite phenacyl moiety on six-membered ring of the bicyclic core was described. The similar synthetic route using the intermediate $\mathbf{3 4}$ was initially attempted (Scheme 6). The phenacylation of 34 gave 35 in 57\% yield. ${ }^{26}$ The following hydrolysis under basic conditions did not work well and gave only tricyclic product 37 or 38, which was supposed by LC-MS analysis. It was considered the undesired product was obtained by cyclization of 6-ethylene moiety with carbonyl at the 5-phenacyl group prior to saponification (Scheme 7). ${ }^{27}$ It was speculated that this cyclization was triggered by higher acidity of methylene in the ethyl group of compound 35 than that of 22d. On the other hand, the hydrolysis of $\mathbf{3 5}$ under acidic condition gave dealkylated compound $\mathbf{3 9}$ as a major product supposed by LC-MS analysis. These results strongly suggested the hydrolysis should be conducted before introduction of 5-phenacyl moiety as described above. 
Scheme 6. Synthesis of carboxylic acid 36 using similar route to $22 d$.
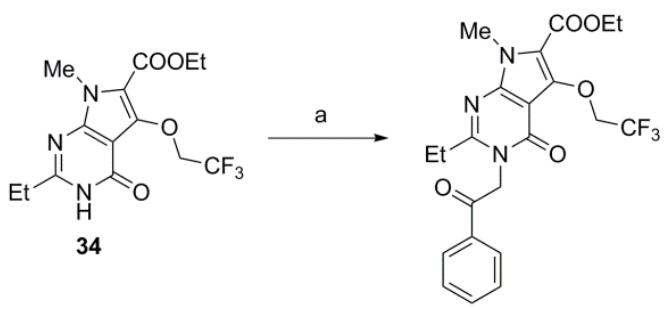

35

\begin{tabular}{ccc}
\hline entry & conditions & major product \\
\hline 1 & $8 \mathrm{M} \mathrm{NaOH}, \mathrm{EtOH} / \mathrm{H}_{2} \mathrm{O}, 60^{\circ} \mathrm{C}$ & 37 \\
2 & $\mathrm{LiOH}, \mathrm{EtOH} / \mathrm{H}_{2} \mathrm{O} / \mathrm{THF}, \mathrm{rt}$ & 38 \\
3 & $\mathrm{HCl}, \mathrm{AcOH}$, reflux & 39 \\
\hline
\end{tabular}

Condition<smiles>CCc1nc2c(c(OCC(F)(F)F)c(C(=O)O)n2C)c(=O)n1CC(=O)c1ccccc1</smiles>

36

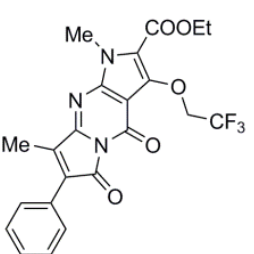

38

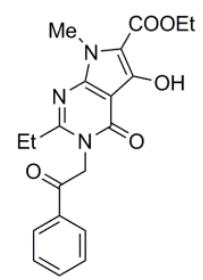

39

Reagents and conditions : (a) phenacyl bromide, tert-BuONa, LiBr, DME, DMF, $60^{\circ} \mathrm{C}, 57 \%$.

Scheme 7. Presumed reaction mechanism of tricyclic compound.

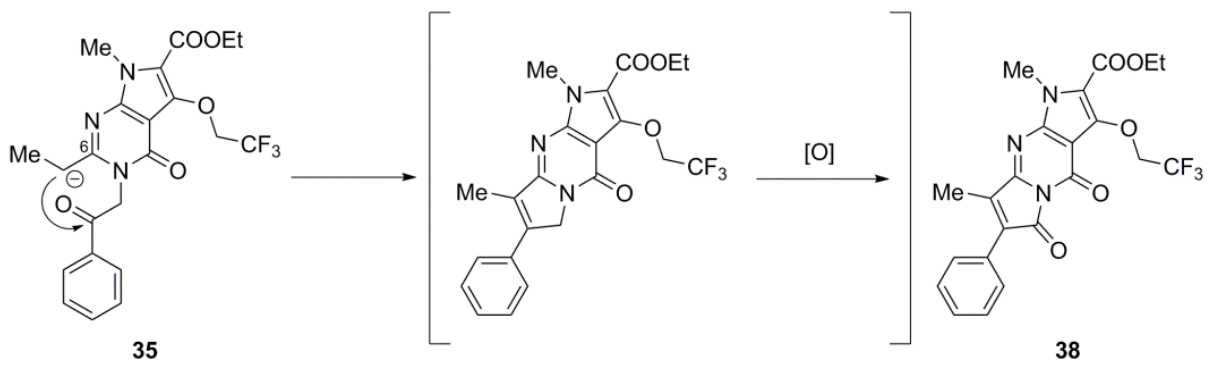

Next, the pyrrolo[2,3-b]pyridine ring was constructed along the synthetic route below (Scheme 8). The hydrogenation of 4-chloropyridine-2-one derivative 16a by palladium-carbon was achieved in 90\% yield. Stepwise halogenation of $\mathbf{4 0}$ was conducted to afford a key intermediate 29b. Addition of sarcosine ethyl ester hydrochloride and cyclization along the synthetic strategy provided $27 \mathbf{b}$. Alkylation of the 3-hydroxy group with (2,2,2-trifluoro)ethyl triflate led to 42 in 96\% yield. Coupling with acetophenone in Buchwald condition gave 26b in $22 \%$ yield, but introduction of amino group to benzophenoneimine gave 43 in 91\% yield. Acylation with benzoyl chloride followed by hydrolysis led to carboxylic acid $\mathbf{2 6 c}$. 
Scheme 8. Synthesis of pyrrolo[2,3-b]pyridine derivatives $\mathbf{2 6 b}$ and $\mathbf{2 6 c}$.<smiles>CCOC(=O)c1c(Cl)cc(CC)[nH]c1=O</smiles>

16a<smiles>CCOC(=O)c1ccc(CC)[nH]c1=O</smiles>

40<smiles>CCCc1[nH]c(=O)c(Br)cc1C(=O)OCC</smiles>

$29 b$

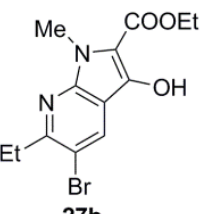

27b

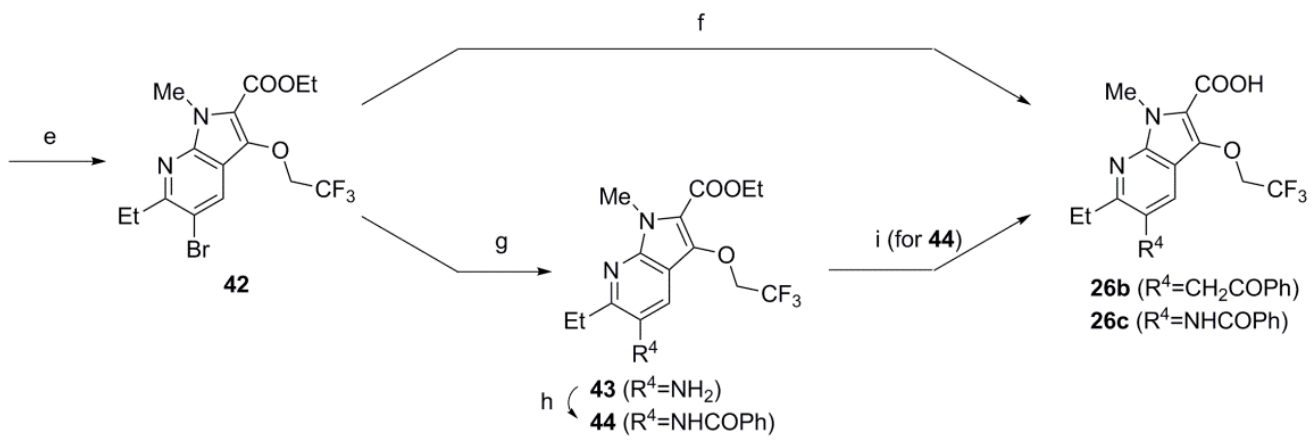

Reagents and conditions : (a) Pd/C, $\mathrm{H}_{2}, \mathrm{Et}_{3} \mathrm{~N}, \mathrm{EtOH}$, THF, 90\%; (b) NBS, DMF, 86\%; (c) $\mathrm{POCl}_{3}$, reflux, 76\%; (d) (1) $\mathrm{MeNHCH}_{2} \mathrm{COOEt} \cdot \mathrm{HCl}, \mathrm{Et}_{3} \mathrm{~N}$, THF, reflux; (2) $\mathrm{NaOEt}, \mathrm{EtOH}, 73 \%$; (e) $\mathrm{CF}_{3} \mathrm{CH}_{2} \mathrm{OTf}$, $\mathrm{Cs}_{2} \mathrm{CO}_{3}$, DMF, 96\%; (f) (1) acetophenone, tert-BuONa, $\mathrm{Pd}(\mathrm{OAc})_{2}$, MePhos, toluene, $70{ }^{\circ} \mathrm{C}$; (2) $\mathrm{NaOH}$, EtOH, $50{ }^{\circ} \mathrm{C}, 22 \%$; (g) (1) benzophenoneimine, $\mathrm{Pd}_{2}(\mathrm{dba})_{3}$, xantphos, $\mathrm{Cs}_{2} \mathrm{CO}_{3}$, toluene, $100{ }^{\circ} \mathrm{C}$; (2) $2 \mathrm{M}$ HCl, THF, 91\%; (h) BzCl, Py, THF, 94\%; (i) NaOH, EtOH, 95\%.

The synthesis of indole derivative 26d is shown in Scheme 9. The key intermediate 29d was synthesized from ethyl 4-bromo-2-chlorobenzoate $\mathbf{4 5}$ as follows; introduction of ethyl group by Stille coupling followed by hydrogenation, and nitration. The construction of $N$-methyl pyrrole ring proceeded directly in $41 \%$ yield. After alkylation of 27d, subsequent hydrogenation of nitro group led to aniline 47 in $97 \%$ yield. Acylation of $\mathbf{4 7}$ with benzoyl chloride followed by saponification were conducted to afford the desired carboxylic acid 26d. 
Scheme 9. Synthesis of indole derivative $\mathbf{2 6 d}$.
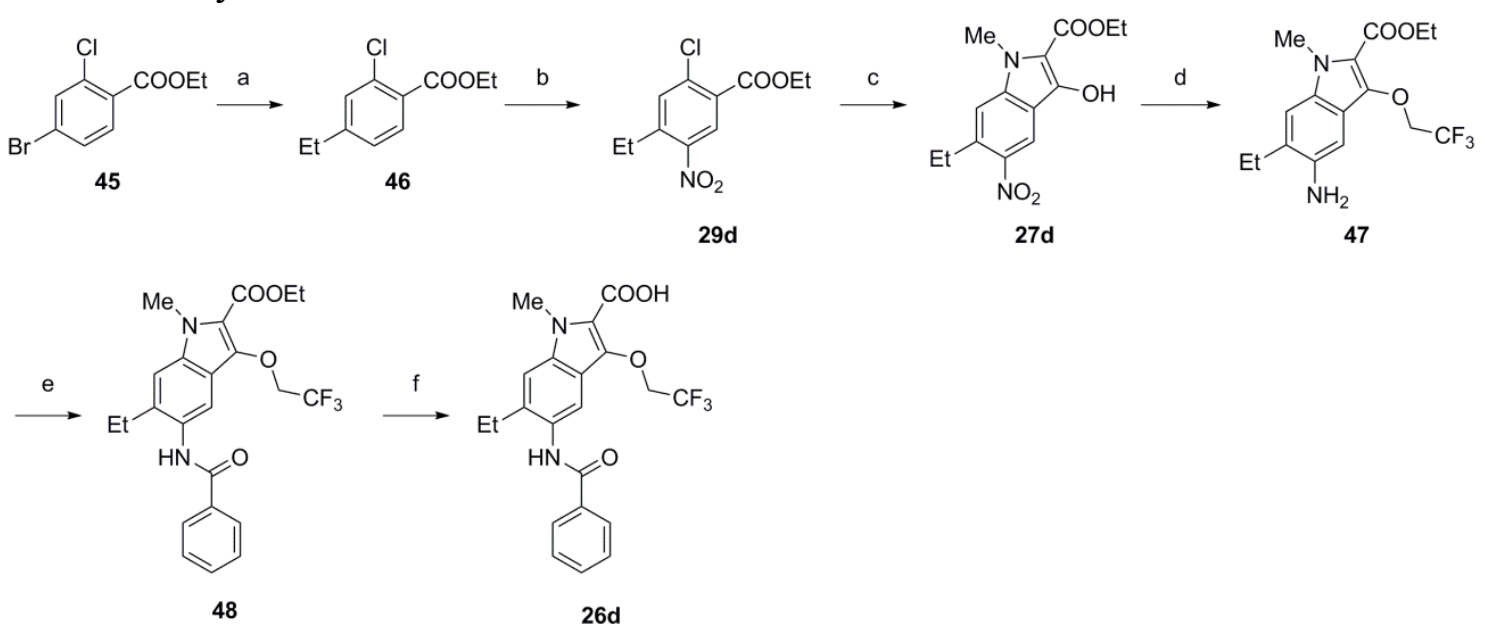

Reagents and conditions : (a) (1) (vinyl) $\mathrm{SnBu}_{3}, \mathrm{Pd}\left(\mathrm{PPh}_{3}\right)_{4}, \mathrm{DMF}, 100{ }^{\circ} \mathrm{C}, 100 \%$; (2) $\mathrm{Pd} / \mathrm{C}, \mathrm{Ba}(\mathrm{OH})_{2}, \mathrm{H}_{2}$, AcOEt, 98\%; (b) $\mathrm{NaNO}_{3}, \mathrm{H}_{2} \mathrm{SO}_{4}, 0{ }^{\circ} \mathrm{C}, 70 \%$; (c) $\mathrm{MeNHCH}_{2} \mathrm{COOEt} \cdot \mathrm{HCl}, \mathrm{Et}_{3} \mathrm{~N}$, EtOH, reflux, 41\%; (d) (1) $\mathrm{CF}_{3} \mathrm{CH}_{2} \mathrm{OTf}, \mathrm{Cs}_{2} \mathrm{CO}_{3}$, DMF, $100 \%$; (2) $\mathrm{Pd} / \mathrm{C}, \mathrm{H}_{2}, \mathrm{EtOH}$, THF, 97\%; (e) $\mathrm{BzCl}$, Py, THF, 86\%; (f) $\mathrm{NaOH}, \mathrm{EtOH}, 95 \%$.

The synthetic route of pyrrolo[3,2-b]pyridine derivative 26e is shown in Scheme 10. The key intermediate 29e was successfully prepared from ethyl 3-bromopicolinate 49 in 3 steps; conversion of bromo to ethyl moiety, successive introduction of hydroxyl and bromo groups. The direct addition of sarcosine ethyl ester was difficult because of its low reactivity of bromo group against nucleophilic substitution, thus stepwise introduction was conducted. The amination of 29e with benzophenoneimine afforded 52 under Buchwald condition. Following monomethylation was achieved via Boc protection. The precursor for Dieckmann condensation 28e was prepared by addition of ethyl bromoacetate. The cyclization of $\mathbf{2 8 e}$ with sodium ethoxide afforded $27 \mathrm{e}$ in $77 \%$ yield. After the alkylation of 3-hydroxyl group, the hydrogenation was carried out to remove benzyl group. Conversion to triflate with trifluoromethanesulfonic anhydride was successively conducted to give 53. The similar reaction in the synthesis of pyrrolo[2,3-b]pyridine 26c afforded carboxylic acid 26e with $N$-benzoyl group at the 5-position. 
Scheme 10. Synthesis of pyrrolo[3,2-b]pyridine derivative 26e.

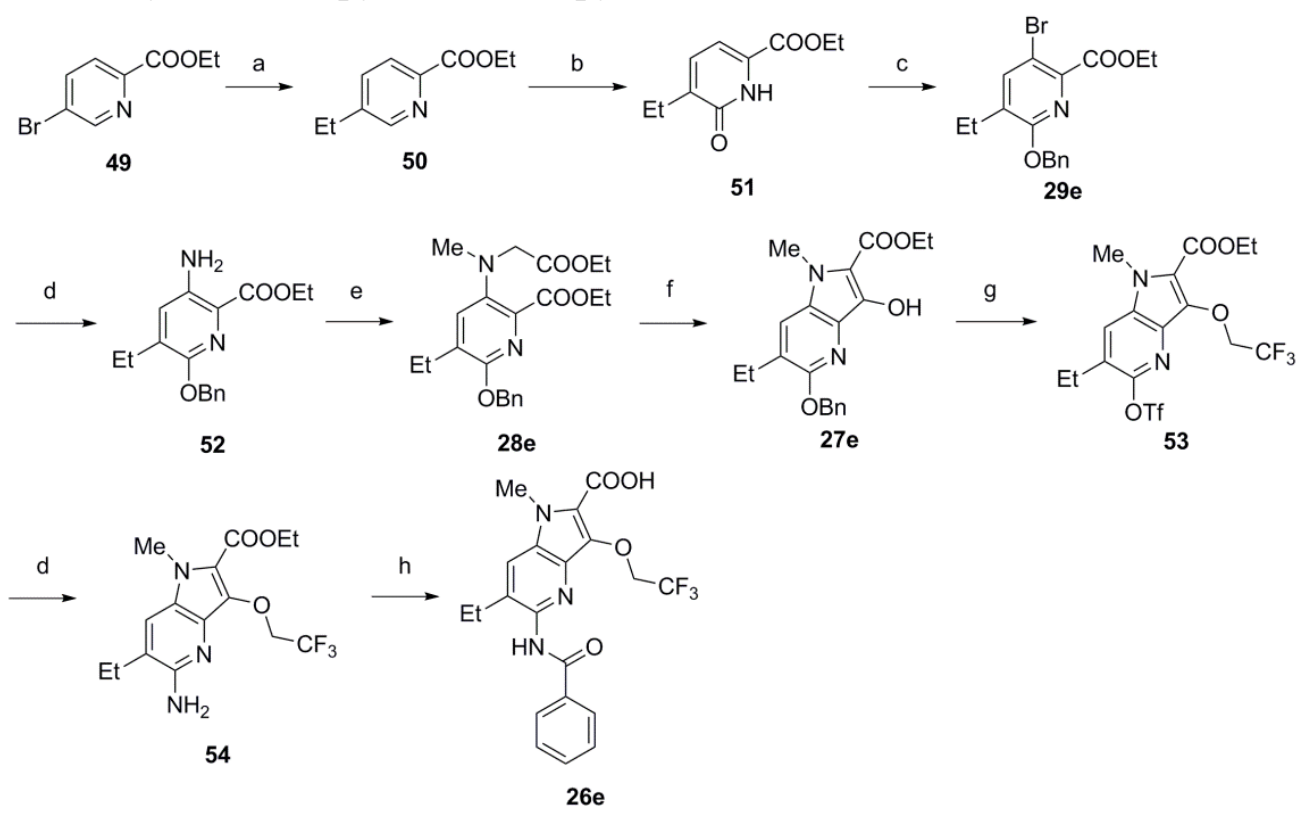

Reagents and conditions : (a) (1) (vinyl) $\mathrm{SnBu}_{3}, \mathrm{Pd}\left(\mathrm{PPh}_{3}\right)_{4}, \mathrm{DMF}, 100{ }^{\circ} \mathrm{C}, 100 \%$; (2) $\mathrm{Pd} / \mathrm{C}, \mathrm{H}_{2}, \mathrm{EtOH}$, $100 \%$; (b) (1) $m \mathrm{CPBA}, \mathrm{MeCN}, 83 \%$; (2) TFAA, DMF, 96\%; (c) (1) NBS, DMF, 79\%; (2) $\mathrm{BnBr}, \mathrm{Ag}_{2} \mathrm{CO}_{3}$, toluene, $40{ }^{\circ} \mathrm{C}$, 99\%; (d) (1) benzophenoneimine, $\mathrm{Pd}_{2}(\mathrm{dba})_{3}$, xantphos, $\mathrm{Cs}_{2} \mathrm{CO}_{3}$, toluene; (2) $2 \mathrm{M} \mathrm{HCl}$, THF, 98\% (for 52), 92\% (for 54); (e) (1) $\mathrm{Boc}_{2} \mathrm{O}$, tert- $\mathrm{BuOH}, 90^{\circ} \mathrm{C}$; (2) MeI, $\mathrm{Cs}_{2} \mathrm{CO}_{3}, \mathrm{DMF}, 87 \%$; (3) $4 \mathrm{M} \mathrm{HCl}$, AcOEt, $0{ }^{\circ} \mathrm{C}$, 87\%; (4) $\mathrm{BrCH}_{2} \mathrm{COOEt}$, iPr $2 \mathrm{NEt}$, DMF, $110{ }^{\circ} \mathrm{C}$, 79\%; (f) NaOEt, EtOH, 77\%; (g) (1) $\mathrm{CF}_{3} \mathrm{CH}_{2} \mathrm{OTf}, \mathrm{Cs}_{2} \mathrm{CO}_{3}$, DMF, 97\%; (2) Pd/C, $\mathrm{H}_{2}$, EtOH, THF, 97\%; (3) Tf $2 \mathrm{O}$, pyridine, $60{ }^{\circ} \mathrm{C}$, 92\%; (h) (1) $\mathrm{BzCl}$, pyridine, THF; (2) $\mathrm{NaOH}$, EtOH, $50{ }^{\circ} \mathrm{C}, 88 \%$.

The synthesis of pyrrolo[2,3-b]pyrazine derivative $\mathbf{2 6 f}$ is shown in Scheme 11. Cyclization of 55 with diethyl ketomalonate gave pyrazine 56 in $25 \%$ yield. Bromination followed by benzylation of $\mathbf{5 6}$ provided 57. Conversion to amino group using Buchwald condition and following acylation with benzoyl chloride afforded 58. The benzyloxy moiety was converted to triflate by hydrogenation and triflation. Addition with sarcosine ethyl ester hydrochloride was achieved at the triflate moiety, and cyclization of pyrrole moiety was prepared in one-pot to give $27 \mathbf{f}$. The obtained alcohol was alkylated with (2,2,2-trifluoro)ethyl triflate, following hydrolysis to give carboxylic acid $\mathbf{2 6 f .}$ 
Scheme 11. Synthesis of pyrrolo[2,3-b]pyrazine derivative $26 \mathbf{f}$.<smiles>CCOc1nc(NC(=O)c2ccccc2)nc(NC(=O)c2ccccc2)n1</smiles>

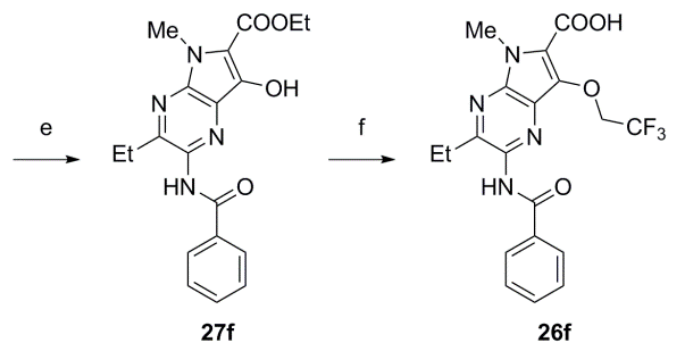

$29 f$

Reagents and conditions : (a) diethyl ketomalonate, $\mathrm{iPr}_{2} \mathrm{NEt}$, EtOH, reflux, 25\%; (b) (1) NBS, DMF; (2) $\mathrm{BnBr}, \mathrm{Ag}_{2} \mathrm{CO}_{3}$, acetone, $91 \%$; (c) (1) benzophenoneimine, $\mathrm{Pd}_{2}(\mathrm{dba})_{3}$, xantphos, $\mathrm{Cs}_{2} \mathrm{CO}_{3}$, toluene, $100{ }^{\circ} \mathrm{C}$; (2) $2 \mathrm{M} \mathrm{HCl}$, THF, 59\%; (3) BzCl, pyridine, THF, $0{ }^{\circ} \mathrm{C}, 93 \%$; (d) (1) $\mathrm{Pd} / \mathrm{C}, \mathrm{H}_{2}$, EtOH, 77\%; (2) $\mathrm{Tf}_{2} \mathrm{O}$, pyridine, $0{ }^{\circ} \mathrm{C}, 94 \%$; (e) (1) $\mathrm{MeNHCH}_{2} \mathrm{COOEtHCl}, \mathrm{Et}_{3} \mathrm{~N}, \mathrm{EtOH}$; (2) $\mathrm{NaOEt}, \mathrm{EtOH}, 80 \%$; (f) (1) $\mathrm{CF}_{3} \mathrm{CH}_{2} \mathrm{OTf}, \mathrm{Cs}_{2} \mathrm{CO}_{3}$, DMF, $0{ }^{\circ} \mathrm{C}, 74 \%$; (2) NaOH, THF, EtOH, 99\%.

Finally, the amidation reaction is listed in Scheme 12. The compound 25a-f was obtained by condensation of corresponding carboxylic acid 26a-f with amine 24 in $46-82 \%$ yield. For the compound 25a, the alkylation with phenacyl bromide was carried out in $14 \%$ yield.

Scheme 12. Amidation reaction in each core ring.

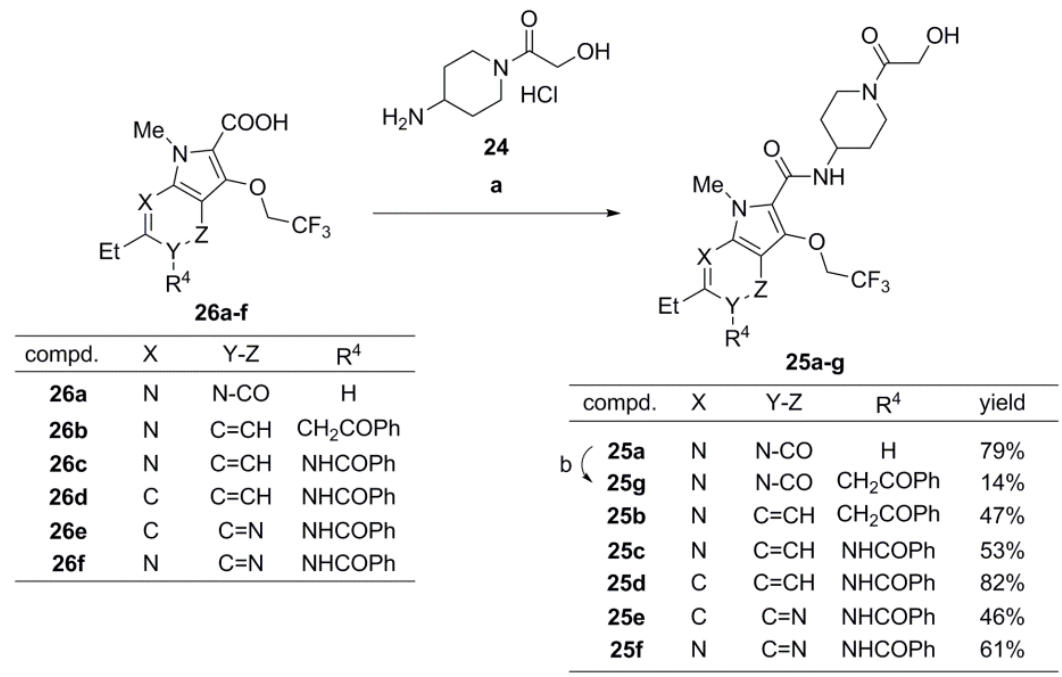

Reagents and conditions : (a) amine 24, $\mathrm{EDC}, \mathrm{HOBt}, \mathrm{Et}_{3} \mathrm{~N}, \mathrm{DMF}, 46-82 \%$.; (b) $\mathrm{BrCH}_{2} \mathrm{COPh}, \mathrm{LiBr}$, $\mathrm{K}_{2} \mathrm{CO}_{3}$, DME/DMF, $60^{\circ} \mathrm{C}$ to $80{ }^{\circ} \mathrm{C}, 14 \%$. 


\subsection{Results and discussion}

\subsubsection{Biological data for hedgehog, and SAR study}

The novel two types of core ring bearing $N$-[1-(hydroxyacetyl)piperidinyl] amide, (2,2,2-trifluoro)ethoxy, phenacyl, and ethyl groups at the same positions as 22d (TAK-441) were initially assessed (Table 9). Pyrrolo[2,3- $d$ ]pyrimidine 25g maintained potent inhibitory activity compared to $2 \mathbf{2 d}$, but the pyrrolo[2,3-b]pyridine $25 \mathbf{b}$ showed 10 -fold drop. This result indicated it might be important for potent inhibitory activity to bear carbonyl group in the core ring. However, the compound 25b still showed $10^{-8}$ order inhibition without carbonyl moiety. It was suggested that the pyrrolo[2,3- $b]$ pyridine ring could be promising core as novel Hh signaling inhibitor by further modification. Next, the enhancement of inhibitory activity in compound $\mathbf{2 5 b}$ was conducted.

Table 9. Effect of core ring with phenacyl group.

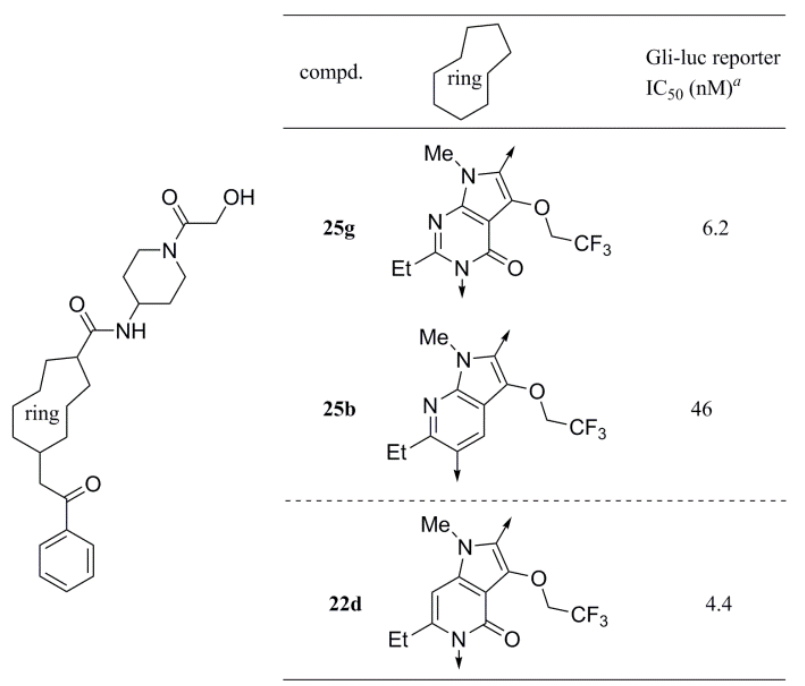

${ }^{a} \mathrm{IC}_{50}$ values are the mean of four measurements.

For this purpose, X-ray single crystal structure of 22d and 25b were obtained (Figure 17). The upper parts of these two compounds were well overlaid. On the other hand, the conformations of terminal benzenes in the 5-phenacyl group were quite different. The 5-phenacyl group of 22d might be influenced by the steric hindrance of both 6-ethyl and 4-carbonyl groups, but lack of the 4-carbonyl group led $25 \mathbf{b}$ to take the different conformation from 22d. Based on these analyses of X-ray single crystal structures, the enhancement of inhibitory activity in $\mathbf{2 5 b}$ could be achieved by adjusting the conformation of terminal benzene ring similar to compound 22d. The decrease of steric hindrance by the lack of 4-carbonyl group induced flexible conformation at the 
5-position, thereby an alternative regulation was necessary for enhancement of inhibitory activity as a surrogate of steric hindrance. As mentioned in the chapter I, the lack of carbonyl group in the side chain or benzene ring resulted in decrease of activity. Considering the current knowledge and necessity of regulation, the benzamide moiety would be a proper substituent at 5-position.

The benzamide was provided the planarity to whole in the 5-position, and regulated the conformation compare to phenacyl group. This structural regulation newly introduced in the 5-position as a surrogate of regulation by steric hindrance in compound 22d brought us expectation that benzamide side chain took the appropriate conformation. Moreover, the rigid benzamide group was advantaged in entropy compared to more flexible phenacyl group because the flexibility loss in binding the target protein was small. ${ }^{28}$ Thus, next effort was shifted to investigation of 5-benzamide derivatives.

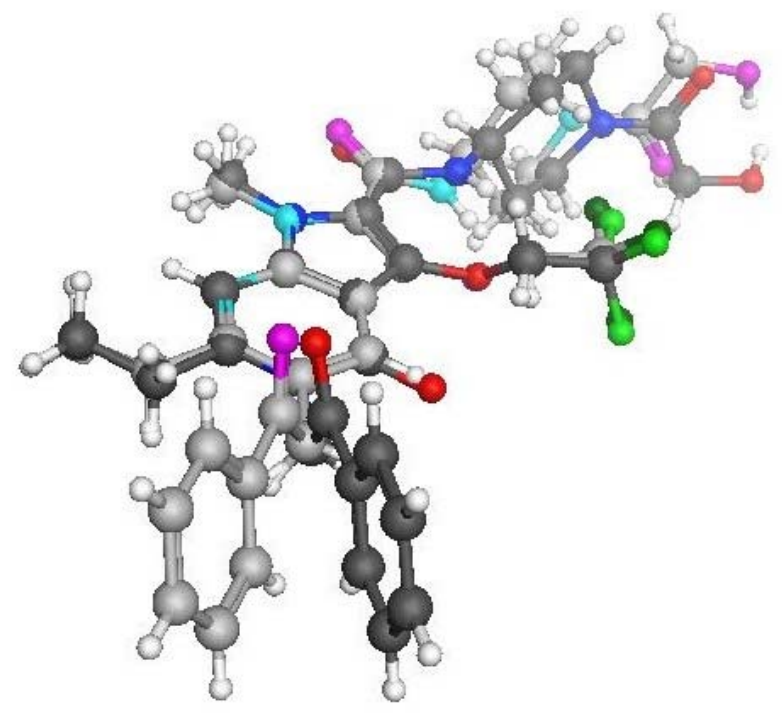

Figure 17. Overlay of 22d (black) and 25b (gray) in X-ray single crystal structure. ${ }^{a}$

${ }^{a}$ The figure was described based on X-ray structural analysis data using PyMOL Software. (PyMOL version 1.4.1)

The compound 25c with benzamide moiety instead of phenacyl group showed dramatic enhancement of Gli-luc reporter inhibitory activity compared to $\mathbf{2 5 b}$ as expected. This finding was next adapted to other novel core skeleton without carbonyl group. Consequently, as the indole 25d, pyrrolo[3,2-b]pyridine 25e and pyrrolo[2,3-b]pyrazine 25f also showed potent inhibitory activity. These results demonstrated that benzamide was quite effective side chain for these novel core skeletons without carbonyl group in the core ring (Table 10). For further consideration, the X-ray single crystal structures of 25d and 25e were obtained and its overlaid figure 
was illustrated in Figure 18.

Table 10. The inhibitory activity and dihedral angle of each novel core ring.
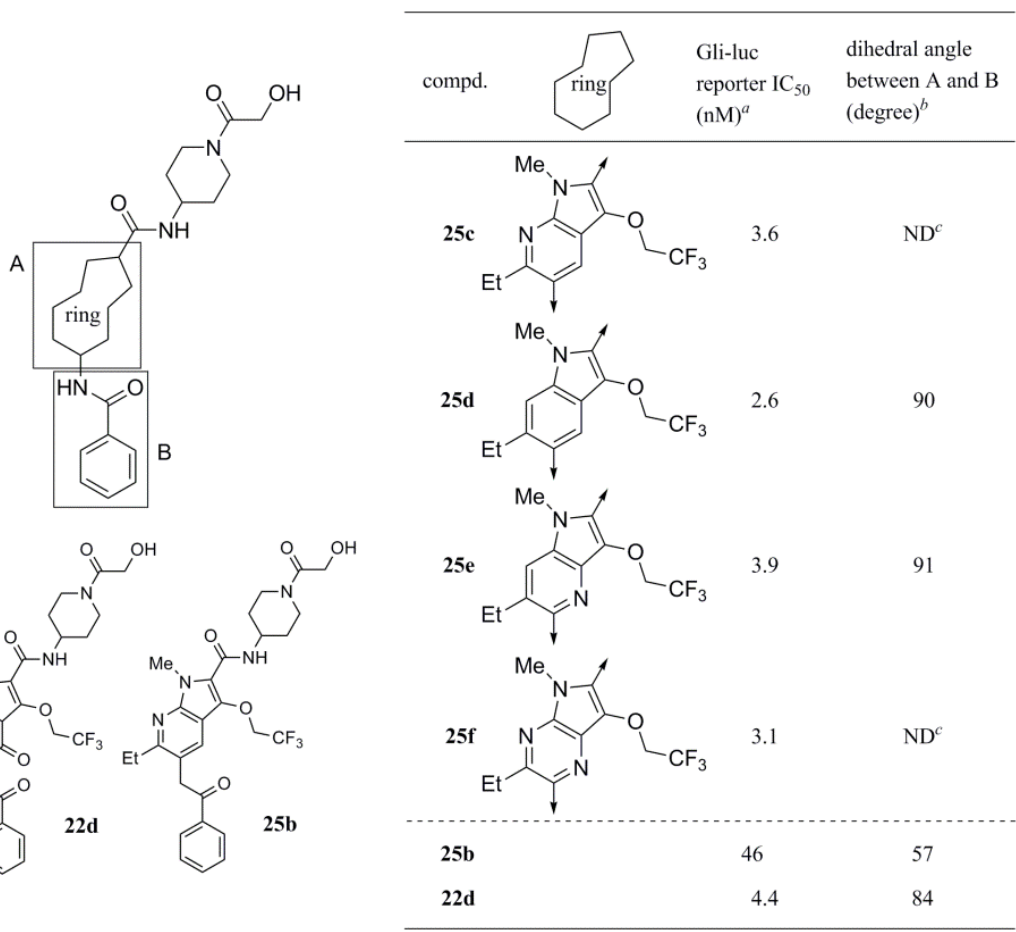

${ }^{a}$ IC50 values are the mean of four measurements.

${ }^{b} \mathrm{~A}$ : least-squares surface of central core, B : least-squares surface of 5-phenacyl or benzamide group.

${ }^{c}$ Not detected.

They also indicated that 5-substituents of 25d and 25e took similar position to that of 22d despite the absence of carbonyl moiety. This conformation was considered to be necessary for potent inhibition of Gli reporter activity as expected. The dihedral angles between central core ring and 5-substituent are also described in Table 10. To notify the relation between inhibitory activity and X-ray single structure, the potent activity requested almost vertical dihedral angle, and its value in 22d, 25d, and 25e were 84, 90 and 91 degrees respectively. It was considered that amide linker formed adequate conformation with dihedral angle of about 90 degrees, and fitted well to whole molecule to the pocket of smo protein. 


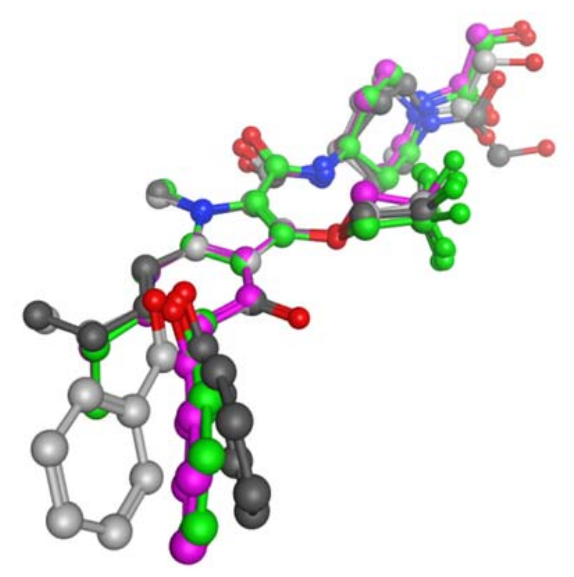

Figure 18. Overlay of 22d (black), 25b (gray), 25d (pink) and 25e (green) in X-ray single crystal structure. ${ }^{a}$

${ }^{a}$ The figure was described based on X-ray structural analysis data using PyMOL Software. (PyMOL version 1.4.1)

\subsubsection{Pharmacodynamic and pharmacokinetic data of 25c-25f}

The in vivo PD profiles of 25c-f are shown in Table 11. PAN-04 is a human pancreatic xenograft tumor line derived from a clinical specimen established by the Central Institute for Experimental Animals (Kanagawa, Japan). This xenograft tumor significantly expressed stroma-derived Glil and cancer-derived Shh activity. The reduction of Gli1 $m$ RNA expression levels was measured as a pharmacodynamic marker in this model. The suppression of Gli1 $m$ RNA expression in novel compounds 25c-f was weaker than 22d despite of their potent in vitro inhibitory activity. It was caused by their pharmacokinetics, which was well correlated to suppression of Gli1 $m$ RNA expression. Considering these results, compound 22d (TAK-441) was well-balanced compound in the point of good PK profile while potent inhibitory activity. 
Table 11. The results of in vivo PD study and corresponding PK data.

\begin{tabular}{cccc}
\hline compd. & $\begin{array}{l}\text { Gli-luc reporter } \\
\mathrm{IC}_{50}(\mathrm{nM})^{a}\end{array}$ & $\begin{array}{l}\text { in vivo PD Gli mRNA } \\
(\% \mathrm{ctrl})\end{array}$ & $\mathrm{AUC}(\mu \mathrm{gh} / \mathrm{mL})^{c}$ \\
\hline $\mathbf{2 5 c}$ & 3.6 & 24 & 10.832 \\
$\mathbf{2 5 d}$ & 2.6 & 50 & 1.272 \\
$\mathbf{2 5 e}$ & 3.9 & 87 & 0.984 \\
$\mathbf{2 5 f}$ & 3.1 & 57 & 0.925 \\
\hline $\mathbf{2 2 d}$ & 4.4 & 4 & 28.346 \\
\hline
\end{tabular}

${ }^{a}$ IC50 values are the mean of four measurements.

${ }^{b}$ Gli1 $m$ RNA expression at $25 \mathrm{mg} / \mathrm{kg}$ BID, $24 \mathrm{~h}$ post-dose. The value indicates Gli1 $m$ RNA expression levels compared to controls. Test compounds were dosed at $25 \mathrm{mg} / \mathrm{kg}$, BID.

${ }^{c}$ Cassette dosing at $10 \mathrm{mg} / \mathrm{kg}$, po in mice. AUC: area under the plasma concentration versus time curve from 0 to $8 \mathrm{~h}$.

\subsection{Conclusion}

The new Hh signaling inhibitors with novel core rings were explored by the modification of 5-substituent including core ring, and pyrrolo[2,3- $b]$ pyridine derivative 25b with $10^{-8}$ order activity in Gli reporter assay was obtained. To enhance in vitro activity, the preferable conformation was considered to show potent inhibiton of Gli reporter activity with X-ray single crystal structure, and compound 25c with benzamide moiety at the 5-position was discovered. The benzamide substituent worked well for the potent inhibitory activity in the core ring without 4-carbonyl moiety, including the indole 25d, pyrrolo[3,2-b]pyridine 25e and pyrrolo[2,3-b]pyrazine 25f. In these compounds, vertical dihedral angle between 5-substituent and core ring might be important for potent inhibitory activity from X-ray crystal structure. The suppression of Gli1 $m$ RNA expression in these novel compounds 25c-f was unfortunately inefficient compare to that of 22d in the result of pharmacokinetics. Based on the results of potent inhibition of Gli reporter activity including structural characteristics and good PK profiles, 22d (TAK-441) is the best candidate as Hh signaling inhibitor. 


\section{Summary}

The author reported the synthetic studies on novel hedgehog signaling inhibitor for cancer therapy. The knowledge which was obtained during the discovery of clinical candidate TAK-441 from hit compound are shown below.

In chapter I, the optimization of hit compound 1a identified from the HTS campaign led to the discovery of $N$-methylpyrrolo[3,2-c]quinoline-4-one derivative 12b bearing $N$-[1-(hydroxyacetyl)piperidinyl] amide at 2-position. 12b suppresses Gli1 $m$ RNA expression reflecting with the potent Gli reporter inhibiton activity and Smo binding inhibition. 12b also shows the in vivo efficacy in mouse medullobrastoma allograft model at $6.25 \mathrm{mg} / \mathrm{kg}$, twice daily. These findings suggested that the $\mathrm{Hh}$ signaling inhibitor could be a therapeutic reagent of cancer.

In chapter II, the optimization of $\mathbf{1 2 b}$ for the improvement of oral absorption at higher dose was reported. The author hypothesized that the oral absorption could be attributed to low solubility, and synthesized the compounds based on reduction of planarity of the compound. As a result of modification, solubility of 6-ethyl pyrroro[3,2-c]pyridine-4-one derivatives was improved while retaining potent inhibition of Gli reporter activity. Further optimization at 3-position for the adjustment of lipophilicity led to the discovery of 22d. 22d also exhibited strong efficacy in mouse medullobrastoma allograft model at $25 \mathrm{mg} / \mathrm{kg}$, and good pharmacokinetics in rats and dogs. On the basis of these findings, 22d could be an orally active candidate for the treatment of cancer.

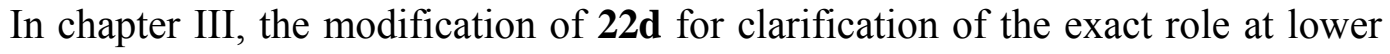
part including core skeleton was conducted. The modification based on X-ray single crystal structure analysis in novel core skeletons was conducted to show potent inhibition of Gli reporter activity. It was found that the vertical dihedral angles between core ring and the substituent at 5-position might be essential for the potency to fit to Smo protein tightly. Eventually, pyrrolo[2,3-d]pyrimidine 25c, indole 25d, pyrrolo[3,2-b]pyridine 25e and pyrrolo[2,3-b]pyrazine 25f were discovered as novel $\mathrm{Hh}$ signaling inhibitors with potency comparable to 22d. Among 22d and 25c-f, 22d showed the strongest suppression of Gli1 $m$ RNA expression derived from good PK. On the basis of these findings, 22d was adequate to select as a clinical candidate of $\mathrm{Hh}$ signaling inhibitor in the point of its structural characteristics and good PK profiles. 
As mentioned above, the discovery of TAK-441 as a clinical candidate of $\mathrm{Hh}$ signaling inhibitor was successfully achieved. The author believes that the knowledge which has been obtained through the discovery of novel Hh signaling inhibitor contributes to the development of pharmaceutical science. 


\section{Acknowledgement}

The author expresses the deepest appreciation to Dr. Shigeki Ohkawa, ex-Chief Scientific Officer of Takeda Pharmaceutical Company Limited, Dr. Hiroyuki Odaka, ex-General Manager, Pharmaceutical Research Division of Takeda Pharmaceutical Company Limited, and Dr. Tetsuyuki Maruyama, General manager, Pharmaceutical Research Division of Takeda Pharmaceutical Company Limited for providing the opportunity to conduct this study. The author expresses his heartfelt gratitude to Dr. Yuji Ishihara, Dr. Kaneyoshi Kato, Dr. Shuichi Furuya, Dr. Osamu Nakanishi, Dr. Keiji Kamiyama and Dr. Takanobu Kuroita for helpful guidance and support.

The author is greatly indebted to Dr. Atsuo Baba, Dr. Satoshi Sasaki, and Dr. Tomoyasu Ishikawa for many invaluable discussions, helpful suggestions, and advice throughout this study.

The author deeply thanks Mr. Hiroshi Banno, Mr. Toshio Tanaka, Dr. Yuya Oguro, Mr. Zenyu Shiokawa, Mr. Yuta Tanaka for the collaborative support and enormous contribution of this thesis.

The author is deeply grateful to Dr. Hideki Tojo, Mr. Sachio Shibata, Dr. Yoshihiro Satoh, Dr. Masahide Kashiwagi, Ms. Harumi Hattori, Ms. Hiroko Yamakawa, Ms. Yukiko Yamamoto and Mr. Shigeru Kondo for the pharmacological study. The author is also deeply grateful to Dr. Mitsuhiro Nishihara, Ms. Maki Miyamoto, for the drug metabolism and pharmacokinetics (DMPK) study, and Dr. Yoshimasa Ishimura, for the safety study. The author greatly appreciate the collaborative support of Mr. Yoichi Nagano, Mr. Motoo Iida, Mr. Mitsuyoshi Nishitani for the X-ray single crystal structure analysis.

The author expresses my gratitude to Professor Daisuke Uemura, Kanagawa University, for great support and encouragement. 


\section{Experimental Section}

\section{General Methods}

Melting points were determined on a Büchi melting point apparatus and were not corrected. Proton nuclear magnetic resonance $\left({ }^{1} \mathrm{H}\right.$ NMR) spectra were recorded on a Varian Gemini-300 (300 MHz) or Bruker DPX300 (300 MHz) instrument or Bruker Avance $300(300 \mathrm{MHz})$. Chemical shifts are reported as $\delta$ values (ppm) downfield from internal tetramethylsilane of the indicated organic solution. Peak multiplicities are expressed using the following abbreviations: s, singlet; $d$, doublet; $t$, triplet; q, quartet; $\mathrm{dd}$, doublet of doublet; ddd, doublet of doublet of doublets; dt, doublet of triplet; br s, broad singlet; $\mathrm{m}$, multiplet. Coupling constants ( $J$ values) are given in hertz $(\mathrm{Hz})$. Element analyses were carried out by Takeda Analytical Laboratories, and the results were within $0.4 \%$ of theoretical values. LC-MS spectra were obtained on a Shimadzu Corporation LC-MS system (LCMS-2010A). Column chromatography was carried out on silica gel columns (Kieselgel 60, 63-200 mesh, Merck, Darmstadt, Germany) or basic silica gel columns (Chromatorex ${ }^{\circledR}$ NH-DM1020, 100-200 mesh, Fuji Silysia

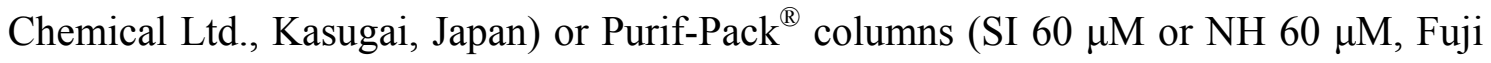
Silysia). Reaction progress was determined by thin layer chromatography (TLC) analysis on silica gel $60 \mathrm{~F}_{254}$ plate (Merck) or NH TLC plates (Fuji Silysia Chemical Ltd.). X-ray structural analyses were determined using MOE version 2010.10; Chemical Computing Group, Inc., Montreal, Quebec, Canada. ClogP values were calculated by Daylight Software ClogP, version 4.82, Daylight Chemical Information Systems, Inc., Aliso Viejo, CA. The purities of compounds submitted for biological evaluation were $\geq 95 \%$ as determined by LC/MS and elemental analysis. Yields are not optimized. 


\section{Experimental section of chapter I}

\section{Ethyl 4-hydroxy-2-oxo-1,2-dihydroquinoline-3-carboxylate (3)}

A $20 \%$ solution of $\mathrm{NaOEt}$ in EtOH (274 g) was added to a solution of methyl anthranilate $(121 \mathrm{~g}, 0.800 \mathrm{~mol})$ and diethyl malonate $(128 \mathrm{~g}, 0.800 \mathrm{~mol})$ in EtOH $(900$ $\mathrm{mL}$ ), and the mixture was stirred at room temperature for $30 \mathrm{~min}$. The mixture was heated at $140{ }^{\circ} \mathrm{C}$ under stirring for $14 \mathrm{~h}$ removing EtOH by a Dean-Stark trap. After cooling, the residual solid was washed with $\mathrm{Et}_{2} \mathrm{O}$ and dissolved in water. After removal of insoluble solid by filtration, the filtrate was acidified with $5 \mathrm{M} \mathrm{HCl}$, and the precipitated solid was collected by filtration. The solid was washed with water and dried in vacuo to give the title compound $(161 \mathrm{~g}, 86 \%)$ as a pale yellow powder. ${ }^{1} \mathrm{H}$ NMR $\left(\mathrm{DMSO}_{6}\right) \delta 1.31(3 \mathrm{H}, \mathrm{t}, J=7.1 \mathrm{~Hz}), 4.34(2 \mathrm{H}, \mathrm{q}, J=7.1 \mathrm{~Hz}), 7.19-7.29(2 \mathrm{H}, \mathrm{m}), 7.63$ $(1 \mathrm{H}, \mathrm{dt}, J=1.2,7.8 \mathrm{~Hz}), 7.94(1 \mathrm{H}, \mathrm{d}, J=8.1 \mathrm{~Hz}), 11.51(1 \mathrm{H}, \mathrm{br} \mathrm{s}), 13.40(1 \mathrm{H}, \mathrm{br} \mathrm{s})$.

\section{Ethyl 2,4-dichloroquinoline-3-carboxylate (4)}

A mixture of $3(75.0 \mathrm{~g}, 0.320 \mathrm{~mol})$ and $\mathrm{POCl}_{3}(200 \mathrm{~mL})$ was stirred at $110{ }^{\circ} \mathrm{C}$ for $6 \mathrm{~h}$. After cooling, the reaction mixture was concentrated in vacuo. The residue was dissolved in a small amount of AcOEt and the mixture was poured into ice water followed by extraction with AcOEt. The extract was washed with $1 \mathrm{M} \mathrm{NaOH}$, water, and brine, dried over $\mathrm{MgSO}_{4}$, and concentrated in vacuo. The residue was purified by basic silica gel column chromatography (AcOEt/hexane $=1 / 5)$ to give the title compound $(68.0 \mathrm{~g}, 79 \%)$ as a white solid. ${ }^{1} \mathrm{H}$ NMR (DMSO- $\left.d_{6}\right) \delta 1.47(3 \mathrm{H}, \mathrm{t}, J=7.2 \mathrm{~Hz}), 4.54(2 \mathrm{H}$, q, $J=7.2 \mathrm{~Hz}), 7.71(1 \mathrm{H}, \mathrm{t}, J=7.5 \mathrm{~Hz}), 7.85(1 \mathrm{H}, \mathrm{t}, J=7.5 \mathrm{~Hz}), 8.06(1 \mathrm{H}, \mathrm{d}, J=8.2 \mathrm{~Hz})$, $8.24(1 \mathrm{H}, \mathrm{d}, J=8.2 \mathrm{~Hz})$.

\section{Ethyl 4-chloro-2-oxo-1,2-dihydroquinoline-3-carboxylate (5)}

A mixture of 4 (68.0 g, $0.250 \mathrm{~mol})$ and $\mathrm{AcONa}(21.7 \mathrm{~g}, 0.260 \mathrm{~mol})$ in $\mathrm{AcOH}$ (200 $\mathrm{mL}$ ) was stirred at $120^{\circ} \mathrm{C}$ for $20 \mathrm{~h}$. After the reaction mixture was added to water, the precipitated solid was collected and washed with water to give the title compound (58.8 g, 94\%) as a white solid. ${ }^{1} \mathrm{H}$ NMR $\left(\mathrm{CDCl}_{3}\right) \delta 1.46(3 \mathrm{H}, \mathrm{t}, J=7.2 \mathrm{~Hz}), 4.53(2 \mathrm{H}, \mathrm{q}, J=$ $7.2 \mathrm{~Hz}), 7.34(1 \mathrm{H}, \mathrm{t}, J=7.8 \mathrm{~Hz}), 7.43(1 \mathrm{H}, \mathrm{d}, J=8.1 \mathrm{~Hz}), 7.63(1 \mathrm{H}, \mathrm{t}, J=7.8 \mathrm{~Hz}), 8.00$ $(1 \mathrm{H}, \mathrm{d}, J=8.1 \mathrm{~Hz}), 12.41(1 \mathrm{H}, \mathrm{br} \mathrm{s})$.

\section{Ethyl 4-chloro-2-oxo-1-(2-oxo-2-phenylethyl)-1,2-dihydroquinoline-3-carboxylate} (6a)

$\mathrm{NaH}(60 \%$ in oil, $1.70 \mathrm{~g}, 41.7 \mathrm{mmol})$ was added to a solution of compound 5 
(10.0 g, $39.7 \mathrm{mmol})$ in DMF (160 mL) under ice-cooling, and the mixture was stirred for $15 \mathrm{~min}$. Phenacyl bromide $(8.70 \mathrm{~g}, 43.7 \mathrm{mmol})$ was added under ice-cooling, and the resulting mixture was stirred for $1 \mathrm{~h}$. The reaction mixture was added to water, and the mixture was extracted with AcOEt. The extract was washed with brine, dried over $\mathrm{MgSO}_{4}$, and concentrated in vacuo. The residue was purified by silica gel column chromatography $(\mathrm{AcOEt} / \mathrm{hexane}=1 / 2$ to $1 / 1)$ to give the title compound $(10.5 \mathrm{~g}, 71 \%)$ as a pale yellow solid. ${ }^{1} \mathrm{H}$ NMR (DMSO- $\left.d_{6}\right) \delta 1.42(3 \mathrm{H}, \mathrm{t}, J=7.2 \mathrm{~Hz}), 4.47(2 \mathrm{H}, \mathrm{q}, J=$ $7.2 \mathrm{~Hz}), 5.80(2 \mathrm{H}, \mathrm{s}), 7.02(1 \mathrm{H}, \mathrm{d}, J=8.1 \mathrm{~Hz}), 7.34(1 \mathrm{H}, \mathrm{t}, J=7.8 \mathrm{~Hz}), 7.53-7.60(3 \mathrm{H}$, m), 7.65-7.70 (1H, m), 8.06-8.13 (3H, m).

\section{Ethyl 4-chloro-1-(4-methoxybenzyl)-2-oxo-1,2-dihydroquinoline-3-carboxylate (6b)}

Similar to the preparation of $\mathbf{6 a}$, the title compound $(10.8 \mathrm{~g}, 79 \%)$ was obtained as a white powder from $5(10.0 \mathrm{~g}, 39.8 \mathrm{mmol}) .{ }^{1} \mathrm{H}$ NMR (DMSO- $\left.d_{6}\right) \delta 1.34(3 \mathrm{H}, \mathrm{t}, J=7.1$ Hz), $3.70(3 \mathrm{H}, \mathrm{s}), 4.40(2 \mathrm{H}, \mathrm{q}, J=7.1 \mathrm{~Hz}), 5.48(2 \mathrm{H}, \mathrm{s}), 6.89(2 \mathrm{H}, \mathrm{d}, J=8.7 \mathrm{~Hz}), 7.19$ $(2 \mathrm{H}, \mathrm{d}, J=8.7 \mathrm{~Hz}), 7.42(1 \mathrm{H}, \mathrm{t}, J=7.8 \mathrm{~Hz}), 7.61(1 \mathrm{H}, \mathrm{d}, J=8.7 \mathrm{~Hz}), 7.69-7.75(1 \mathrm{H}, \mathrm{m})$, $8.04(1 \mathrm{H}, \mathrm{dd}, J=7.8,1.2 \mathrm{~Hz})$.

\section{Ethyl 3-hydroxy-4-oxo-5-(2-oxo-2-phenylethyl)-4,5-dihydrothieno[3,2-c]quinoline -2-carboxylate (7a)}

A mixture of ethyl thioglycolate $(6.10 \mathrm{~g}, 50.5 \mathrm{mmol}), 20 \%$ solution of $\mathrm{NaOEt}$ in $\mathrm{EtOH}(17.2 \mathrm{~g}, 50.5 \mathrm{mmol})$, and $\mathrm{EtOH}(50 \mathrm{~mL})$ was stirred at room temperature for 5 min. Compound 6a $(9.30 \mathrm{~g}, 25.3 \mathrm{mmol})$ was added and the mixture was stirred at room temperature for $18 \mathrm{~h}$. The mixture was acidified with $2 \mathrm{M} \mathrm{HCl}$ and the resulting mixture was stirred for $30 \mathrm{~min}$. The precipitated solid was collected by filtration, washed with water and $\mathrm{Et}_{2} \mathrm{O}$ to give the title compound $(10.0 \mathrm{~g}, 96 \%)$ as a white powder. ${ }^{1} \mathrm{H}$ NMR (DMSO- $\left.d_{6}\right) \delta 1.32(3 \mathrm{H}, \mathrm{t}, J=7.0 \mathrm{~Hz}), 4.25-4.35(2 \mathrm{H}, \mathrm{m}), 6.01(2 \mathrm{H}, \mathrm{s}), 7.40$ $(1 \mathrm{H}, \mathrm{t}, J=7.2 \mathrm{~Hz}), 7.55-7.67(4 \mathrm{H}, \mathrm{m}), 7.77(1 \mathrm{H}, \mathrm{t}, J=7.5 \mathrm{~Hz}), 8.00-8.07(1 \mathrm{H}, \mathrm{m})$, 8.07-8.19 (2H, m), $10.57(1 \mathrm{H}$, br s).

\section{Ethyl 3-hydroxy-4-oxo-5-(2-oxo-2-phenylethyl)-4,5-dihydrofuro[3,2-c]quinoline-2- carboxylate (7b)}

Similar to the preparation of $7 \mathrm{a}$, the title compound $(1.10 \mathrm{~g}, 69 \%)$ was obtained as a white powder from $6 \mathrm{a}(1.50 \mathrm{~g}, 4.06 \mathrm{mmol}) .{ }^{1} \mathrm{H}$ NMR $\left(\mathrm{DMSO}-d_{6}\right) \delta 1.34(3 \mathrm{H}, \mathrm{t}, J=$ $7.1 \mathrm{~Hz}), 4.35(2 \mathrm{H}, \mathrm{q}, J=7.1 \mathrm{~Hz}), 5.96(2 \mathrm{H}, \mathrm{s}), 7.39(1 \mathrm{H}, \mathrm{t}, J=7.7 \mathrm{~Hz}), 7.51(1 \mathrm{H}, \mathrm{d}, J=$ 8.4 Hz), 7.60-7.67 (3H, m), 7.74-7.79 (1H, m), 8.05 (1H, dd, $J=7.7,1.4 \mathrm{~Hz}), 8.15-8.18$ $(2 \mathrm{H}, \mathrm{m}), 10.55(1 \mathrm{H}$, br s). 
Ethyl 3-hydroxy-1-methyl-4-oxo-5-(2-oxo-2-phenylethyl)-4,5-dihydro-1Hpyrrolo[3,2-c]quinoline-2-carboxylate (7c)

A mixture of $6 \mathrm{a}(52.0 \mathrm{~g}, 0.14 \mathrm{~mol})$, sarcosine ethyl ester hydrochloride $(25.6 \mathrm{~g}$, $0.16 \mathrm{~mol}), \mathrm{Et}_{3} \mathrm{~N}(28.5 \mathrm{~g}, 0.28 \mathrm{~mol})$, and $\mathrm{EtOH}(500 \mathrm{~mL})$ was stirred at $85{ }^{\circ} \mathrm{C}$ for $12 \mathrm{~h}$. After cooling, the mixture was diluted with water $(2200 \mathrm{~mL})$ and extracted with AcOEt. The combined extracts were washed with brine, dried over $\mathrm{MgSO}_{4}$, and concentrated in vacuo. The residue was crystallized with hexane/AcOEt to give the ethyl 4-[(2-ethoxy-2-oxoethyl)(methyl)amino]-2-oxo-1-(2-oxo-2-phenylethyl)-1,2-dihydroqui noline-3-carboxylate $(51.5 \mathrm{~g})$ as pale yellow crystals. A mixture of the compound (51.5 g) obtained above, 20\% solution of NaOEt in EtOH (46.6 g, $0.14 \mathrm{~mol}$ ), and EtOH $(1000 \mathrm{~mL})$ was stirred at $50{ }^{\circ} \mathrm{C}$ for $18 \mathrm{~h}$. The mixture was diluted with water $(500 \mathrm{~mL})$ then acidified with $1 \mathrm{M} \mathrm{HCl}(140 \mathrm{~mL})$, the resulting mixture was stirred for $30 \mathrm{~min}$. The precipitated solid was collected by filtration, washed with water and EtOH successively, and dried in vacuo to give the title compound $(37.5 \mathrm{~g}, 66 \%)$ as a white solid. ${ }^{1} \mathrm{H}$ NMR (DMSO- $\left.d_{6}\right) \delta 1.33(3 \mathrm{H}, \mathrm{t}, J=7.2 \mathrm{~Hz}), 4.30-4.38(5 \mathrm{H}, \mathrm{m}), 5.93(2 \mathrm{H}, \mathrm{s})$, 7.30-7.40 (2H, m), 7.48-7.53 (1H, m), 7.61-7.66 (2H, m), 7.73-7.79 (1H, m), 8.15-8.18 $(2 \mathrm{H}, \mathrm{m}), 8.34-8.37(1 \mathrm{H}, \mathrm{m}), 9.00(1 \mathrm{H}, \mathrm{s})$. Anal. calcd for $\mathrm{C}_{23} \mathrm{H}_{20} \mathrm{~N}_{2} \mathrm{O}_{5}: \mathrm{C}, 68.31 ; \mathrm{H}$, 4.98; N, 6.93. Found: C, 68.41; H, 5.08; N, 7.11.

Ethyl 3-hydroxy-5-(4-methoxybenzyl)-1-methyl-4-oxo-4,5-dihydro-1H-pyrrolo [3,2-c]quinoline-2-carboxylate (7d)

A mixture of $6 \mathbf{b}(16.5 \mathrm{~g}, 44.47 \mathrm{mmol})$, sarcosine ethyl ester hydrochloride (10.2 g, $66.5 \mathrm{mmol}), \mathrm{Et}_{3} \mathrm{~N}(27.5 \mathrm{~mL}, 0.197 \mathrm{~mol})$, and $\mathrm{EtOH}(170 \mathrm{~mL})$ was stirred at $85^{\circ} \mathrm{C}$ for 18 h. A $20 \%$ solution of NaOEt in EtOH (75.3 g, $0.221 \mathrm{~mol})$ was added, and the mixture was stirred at $60{ }^{\circ} \mathrm{C}$ for $1 \mathrm{~h}$. The mixture was concentrated in vacuo, and the residue was suspended with water $(100 \mathrm{~mL})$. The suspension was acidified with $5 \mathrm{M} \mathrm{HCl}$ at $0{ }^{\circ} \mathrm{C}$, and the mixture was stirred at room temperature for $1.5 \mathrm{~h}$. The precipitate was collected by filtration, washed with water and $\mathrm{EtOH}$ to give the title compound (14.6 g, $81 \%$ ) as a brown solid. ${ }^{1} \mathrm{H}$ NMR (DMSO- $\left.d_{6}\right) \delta 1.33(3 \mathrm{H}, \mathrm{t}, J=7.0 \mathrm{~Hz}), 3.69(3 \mathrm{H}, \mathrm{s})$, $4.28(3 \mathrm{H}, \mathrm{s}), 4.34(2 \mathrm{H}, \mathrm{q}, J=7.0 \mathrm{~Hz}), 5.48(2 \mathrm{H}, \mathrm{br} \mathrm{s}), 6.80-6.93(2 \mathrm{H}, \mathrm{m}), 7.16(2 \mathrm{H}, \mathrm{d}, J$ $=8.7 \mathrm{~Hz}), 7.23-7.35(1 \mathrm{H}, \mathrm{m}), 7.43-7.52(2 \mathrm{H}, \mathrm{m}), 8.33(1 \mathrm{H}, \mathrm{d}, J=8.1 \mathrm{~Hz}), 9.10(1 \mathrm{H}, \mathrm{s})$.

\section{Ethyl 3-methoxy-4-0xo-5-(2-oxo-2-phenylethyl)-4,5-dihydrothieno[3,2-c]quinoline}

\section{-2-carboxylate (8a)}

DBU (4.30 g, $18.3 \mathrm{mmol})$ was added at room temperature to a stirred solution of compound 7a $(7.00 \mathrm{~g}, 17.1 \mathrm{mmol})$ in DMF $(150 \mathrm{~mL})$. After stirring for $10 \mathrm{~min}$, MeI 
(4.00 g, $28.0 \mathrm{mmol})$ was added. The mixture was stirred at room temperature for $4 \mathrm{~h}$, and concentrated in vacuo. The residue was diluted with water, and extracted with AcOEt/THF. The organic layer was washed with brine, dried over $\mathrm{MgSO}_{4}$, and concentrated in vacuo. The residual solid was collected and washed with $\mathrm{AcOEt} / \mathrm{Et}_{2} \mathrm{O}$ to give the title compound $(5.70 \mathrm{~g}, 79 \%)$ as a pale green powder. ${ }^{1} \mathrm{H}$ NMR (DMSO- $d_{6}$ ) $\delta 1.34(3 \mathrm{H}, \mathrm{t}, J=7.1 \mathrm{~Hz}), 3.95(3 \mathrm{H}, \mathrm{s}), 4.34(2 \mathrm{H}, \mathrm{q}, J=7.1 \mathrm{~Hz}), 5.98(2 \mathrm{H}, \mathrm{s}), 7.37(1 \mathrm{H}$, t, $J=7.5 \mathrm{~Hz}), 7.49(1 \mathrm{H}, \mathrm{d}, J=8.7 \mathrm{~Hz}), 7.57-7.67(3 \mathrm{H}, \mathrm{m}), 7.76(1 \mathrm{H}, \mathrm{t}, J=7.5 \mathrm{~Hz}), 8.06$ $(1 \mathrm{H}, \mathrm{d}, J=7.8 \mathrm{~Hz}), 8.16-8.19(2 \mathrm{H}, \mathrm{m})$.

The following compounds 8b-e were prepared in a manner similar to that described for $\mathbf{8 a}$.

Ethyl 3-methoxy-4-oxo-5-(2-oxo-2-phenylethyl)-4,5-dihydrofuro[3,2-c]quinoline-2carboxylate (8b)

Yield 23\%, white powder. ${ }^{1} \mathrm{H}$ NMR (DMSO- $\left.d_{6}\right) \delta 1.35(3 \mathrm{H}, \mathrm{t}, J=7.1 \mathrm{~Hz}), 4.14$ $(3 \mathrm{H}, \mathrm{s}), 4.37(2 \mathrm{H}, \mathrm{q}, J=7.1 \mathrm{~Hz}), 5.99(2 \mathrm{H}, \mathrm{s}), 7.39-7.45(1 \mathrm{H}, \mathrm{m}), 7.55(1 \mathrm{H}, \mathrm{d}, J=8.7$ $\mathrm{Hz}), 7.62-7.68(3 \mathrm{H}, \mathrm{m}), 7.74-7.80(1 \mathrm{H}, \mathrm{m}), 8.09(1 \mathrm{H}, \mathrm{dd}, J=7.8,1.5 \mathrm{~Hz}), 8.16-8.18$ $(2 \mathrm{H}, \mathrm{m})$. Anal. calcd for $\mathrm{C}_{23} \mathrm{H}_{19} \mathrm{NO}_{6}: \mathrm{C}, 68.14 ; \mathrm{H}, 4.72 ; \mathrm{N}, 3.46$. Found: $\mathrm{C}, 67.91 ; \mathrm{H}$, $4.78 ; \mathrm{N}, 3.42$.

Ethyl

3-methoxy-1-methyl-4-oxo-5-(2-oxo-2-phenylethyl)-4,5-dihydro-1Hpyrrolo[3,2-c]quinoline-2-carboxylate (8c)

Yield 55\%, white powder. ${ }^{1} \mathrm{H}$ NMR (DMSO- $\left.d_{6}\right) \delta 1.35(3 \mathrm{H}, \mathrm{t}, J=7.1 \mathrm{~Hz}), 3.89$ $(3 \mathrm{H}, \mathrm{s}), 4.29-4.37(5 \mathrm{H}, \mathrm{m}), 5.96(2 \mathrm{H}, \mathrm{s}), 7.30-7.40(2 \mathrm{H}, \mathrm{m}), 7.48-7.53(1 \mathrm{H}, \mathrm{m})$, 7.61-7.66 (2H, m), 7.73-7.78 (1H, m), 8.15-8.18 (2H, m), 8.38 (1H, dd, $J=8.3,1.4 \mathrm{~Hz})$. Anal. calcd for $\mathrm{C}_{24} \mathrm{H}_{22} \mathrm{~N}_{2} \mathrm{O}_{5}: \mathrm{C}, 68.89 ; \mathrm{H}, 5.30 ; \mathrm{N}, 6.69$. Found: $\mathrm{C}, 68.52 ; \mathrm{H}, 5.26 ; \mathrm{N}$, 6.61 .

Ethyl

3-ethoxy-1-methyl-4-oxo-5-(2-oxo-2-phenylethyl)-4,5-dihydro-1Hpyrrolo[3,2-c]quinoline-2-carboxylate (8d)

Yield 100\%, white powder. ${ }^{1} \mathrm{H}$ NMR (DMSO- $\left.d_{6}\right) \delta 1.27-1.37(6 \mathrm{H}, \mathrm{m}), 4.16(2 \mathrm{H}$, q, $J=6.9 \mathrm{~Hz}), 4.29-4.36(5 \mathrm{H}, \mathrm{m}), 5.95(2 \mathrm{H}, \mathrm{s}), 7.27-7.39(2 \mathrm{H}, \mathrm{m}), 7.50(1 \mathrm{H}, \mathrm{t}, J=8.0$ $\mathrm{Hz}), 7.63(2 \mathrm{H}, \mathrm{t}, J=7.3 \mathrm{~Hz}), 7.76(1 \mathrm{H}, \mathrm{t}, J=7.4 \mathrm{~Hz}), 8.17(2 \mathrm{H}, \mathrm{d}, J=7.3 \mathrm{~Hz}), 8.38(1 \mathrm{H}$, $\mathrm{d}, J=8.1 \mathrm{~Hz})$. 
Ethyl 3-methoxy-5-(4-methoxybenzyl)-1-methyl-4-oxo-4,5-dihydro-1H-pyrrolo [3,2-c]quinoline-2-carboxylate (8e)

Yield 61\%, pale yellow solid. ${ }^{1} \mathrm{H}$ NMR (DMSO- $\left.d_{6}\right) \delta 1.35(3 \mathrm{H}, \mathrm{t}, J=7.1 \mathrm{~Hz})$, $3.69(3 \mathrm{H}, \mathrm{s}), 3.94(3 \mathrm{H}, \mathrm{s}), 4.26(3 \mathrm{H}, \mathrm{s}), 4.34(2 \mathrm{H}, \mathrm{q}, J=7.1 \mathrm{~Hz}), 5.51(2 \mathrm{H}, \mathrm{br} \mathrm{s}), 6.86$ $(2 \mathrm{H}, \mathrm{d}, J=8.7 \mathrm{~Hz}), 7.15(2 \mathrm{H}, \mathrm{d}, J=8.7 \mathrm{~Hz}), 7.25-7.31(1 \mathrm{H}, \mathrm{m}), 7.47(2 \mathrm{H}, \mathrm{d}, J=3.6$ $\mathrm{Hz}), 8.34(1 \mathrm{H}, \mathrm{d}, J=8.1 \mathrm{~Hz})$.

\section{3-Methoxy-4-oxo-5-(2-oxo-2-phenylethyl)-4,5-dihydrothieno[3,2-c]quinoline-2- carboxylic acid (9a)}

A solution of $8 \mathrm{a}(5.70 \mathrm{~g}, 13.5 \mathrm{mmol})$ and $2 \mathrm{M} \mathrm{NaOH}(60 \mathrm{~mL})$ in THF (200 $\mathrm{mL}) / \mathrm{EtOH}(100 \mathrm{~mL})$ was stirred at room temperature for $18 \mathrm{~h}$. The reaction mixture was neutralized with $2 \mathrm{M} \mathrm{HCl}$, and the resulting solid was collected by filtration. The solid was washed with water and $\mathrm{Et}_{2} \mathrm{O}$ to give the title compound $(4.20 \mathrm{~g}, 79 \%)$ as a pale pink powder. ${ }^{1} \mathrm{H}$ NMR (DMSO- $\left.d_{6}\right) \delta 3.93(3 \mathrm{H}, \mathrm{s}), 5.98(2 \mathrm{H}, \mathrm{s}), 7.35(1 \mathrm{H}, \mathrm{t}, J=$ $7.8 \mathrm{~Hz}), 7.48(1 \mathrm{H}, \mathrm{d}, J=8.7 \mathrm{~Hz}), 7.56-7.67(3 \mathrm{H}, \mathrm{m}), 7.77(1 \mathrm{H}, \mathrm{t}, J=7.2 \mathrm{~Hz}), 8.04(1 \mathrm{H}$, $\mathrm{dd}, J=8.1,1.2 \mathrm{~Hz}), 8.16-8.19(2 \mathrm{H}, \mathrm{m}), 13.43(1 \mathrm{H}, \mathrm{s})$.

The following compounds 9b-e were prepared in a manner similar to that described for $\mathbf{9 a}$.

\section{3-Methoxy-4-oxo-5-(2-oxo-2-phenylethyl)-4,5-dihydrofuro[3,2-c]quinoline-2-}

\section{carboxylic acid (9b)}

Yield $72 \%$, white powder. ${ }^{1} \mathrm{H}$ NMR (DMSO- $\left.d_{6}\right) \delta 4.12(3 \mathrm{H}, \mathrm{s}), 5.99(2 \mathrm{H}, \mathrm{s})$, $7.42(1 \mathrm{H}, \mathrm{t}, J=7.6 \mathrm{~Hz}), 7.54(1 \mathrm{H}, \mathrm{d}, J=7.8 \mathrm{~Hz}), 7.62-7.67(3 \mathrm{H}, \mathrm{m}), 7.77(1 \mathrm{H}, \mathrm{t}, J=7.8$ $\mathrm{Hz}), 8.07(1 \mathrm{H}, \mathrm{dd}, J=7.6,1.5 \mathrm{~Hz}), 8.16-8.18(2 \mathrm{H}, \mathrm{m}), 13.35(1 \mathrm{H}, \mathrm{br} \mathrm{s})$.

\section{3-Methoxy-1-methyl-4-oxo-5-(2-oxo-2-phenylethyl)-4,5-dihydro-1H-pyrrolo[3,2-c]} quinoline-2-carboxylic acid (9c)

Yield 91\%, white powder. ${ }^{1} \mathrm{H}$ NMR (DMSO- $\left.d_{6}\right) \delta 3.88(3 \mathrm{H}, \mathrm{s}), 4.31(3 \mathrm{H}, \mathrm{s})$, $5.95(2 \mathrm{H}, \mathrm{s}), 7.29-7.39(2 \mathrm{H}, \mathrm{m}), 7.46-7.52(1 \mathrm{H}, \mathrm{m}), 7.61-7.66(2 \mathrm{H}, \mathrm{m}), 7.73-7.78(1 \mathrm{H}$, $\mathrm{m}), 8.16-8.18(2 \mathrm{H}, \mathrm{m}), 8.38(1 \mathrm{H}, \mathrm{dd}, J=8.3,1.1 \mathrm{~Hz}), 12.92(1 \mathrm{H}, \mathrm{s})$.

\section{3-Ethoxy-1-methyl-4-oxo-5-(2-oxo-2-phenylethyl)-4,5-dihydro-1H-pyrrolo[3,2-c]} quinoline-2-carboxylic acid (9d)

Yield 89\%, white powder. ${ }^{1} \mathrm{H}$ NMR (DMSO- $\left.d_{6}\right) \delta 1.27(3 \mathrm{H}, \mathrm{t}, J=7.0 \mathrm{~Hz}), 4.16$ $(2 \mathrm{H}, \mathrm{q}, J=7.0 \mathrm{~Hz}), 4.31(3 \mathrm{H}, \mathrm{s}), 5.95(2 \mathrm{H}, \mathrm{s}), 7.27-7.39(2 \mathrm{H}, \mathrm{m}), 7.49(1 \mathrm{H}, \mathrm{t}, J=7.4$ 
$\mathrm{Hz}), 7.63(2 \mathrm{H}, \mathrm{t}, J=7.4 \mathrm{~Hz}), 7.76(1 \mathrm{H}, \mathrm{t}, J=7.4 \mathrm{~Hz}), 8.15-8.18(2 \mathrm{H}, \mathrm{m}), 8.38(1 \mathrm{H}, \mathrm{d}, J$ $=7.2 \mathrm{~Hz}), 12.83(1 \mathrm{H}, \mathrm{s})$. Anal. calcd for $\mathrm{C}_{23} \mathrm{H}_{20} \mathrm{~N}_{2} \mathrm{O}_{5} \bullet \mathrm{H}_{2} \mathrm{O}: \mathrm{C}, 65.39 ; \mathrm{H}, 5.25 ; \mathrm{N}, 6.63$. Found: C, 65.65; H, 4.95; N, 6.73.

\section{3-Methoxy-5-(4-methoxybenzyl)-1-methyl-4-oxo-4,5-dihydro-1H-pyrrolo[3,2-c] quinoline-2-carboxylic acid (9e)}

Yield 96\%, pale yellow solid. ${ }^{1} \mathrm{H}$ NMR (DMSO- $\left.d_{6}\right) \delta 3.70(3 \mathrm{H}, \mathrm{s}), 3.94(3 \mathrm{H}, \mathrm{s})$, $4.28(3 \mathrm{H}, \mathrm{s}), 5.51(2 \mathrm{H}, \mathrm{br} \mathrm{s}), 6.86(2 \mathrm{H}, \mathrm{d}, J=8.7 \mathrm{~Hz}), 7.15(2 \mathrm{H}, \mathrm{d}, J=8.7 \mathrm{~Hz})$, 7.25-7.30 (1H, m), $7.46(2 \mathrm{H}, \mathrm{d}, J=3.9 \mathrm{~Hz}), 8.34(1 \mathrm{H}, \mathrm{d}, J=8.4 \mathrm{~Hz}), 12.90$ (1H, br s).

\section{3-Methoxy-4-oxo-5-(2-oxo-2-phenylethyl)- $N$-(2-pyrrolidin-1-ylethyl)-4,5-dihydro- thieno[3,2-c]quinoline-2-carboxamide (1a)}

EDC (94 mg, $0.49 \mathrm{mmol})$ was added to a mixture of 9a $(130 \mathrm{mg}, 0.33 \mathrm{mmol})$, 1-(2-aminoethyl)-pyrrolidine (56 mg, $0.49 \mathrm{mmol})$, and HOBt $(67 \mathrm{mg}, 0.49 \mathrm{mmol})$ in DMF ( $4 \mathrm{~mL})$, and the mixture was stirred at room temperature for $18 \mathrm{~h}$. The reaction mixture was diluted with saturated $\mathrm{NaHCO}_{3}$ aq. and extracted twice with AcOEt. The combined organic extracts were washed with brine, dried over $\mathrm{MgSO}_{4}$, and concentrated in vacuo. The residue was purified by basic silica gel column chromatography (hexane/AcOEt $=1 / 1$ to $0 / 1$ ), and crystallized from hexane/AcOEt to give the title compound $(100 \mathrm{mg}, 62 \%)$ as white crystals; mp. $190{ }^{\circ} \mathrm{C} .{ }^{1} \mathrm{H}$ NMR $\left(\mathrm{DMSO}-d_{6}\right) \delta 1.72(4 \mathrm{H}, \mathrm{br} \mathrm{s}), 2.49(4 \mathrm{H}, \mathrm{m}), 2.64(2 \mathrm{H}, \mathrm{t}, J=6.3 \mathrm{~Hz}), 3.44(2 \mathrm{H}, \mathrm{t}, J=5.9$ $\mathrm{Hz}), 4.01(3 \mathrm{H}, \mathrm{s}), 6.00(2 \mathrm{H}, \mathrm{s}), 7.35(1 \mathrm{H}, \mathrm{t}, J=7.8 \mathrm{~Hz}), 7.49(1 \mathrm{H}, \mathrm{d}, J=8.1 \mathrm{~Hz})$, 7.55-7.67 (3H, m), $7.76(1 \mathrm{H}, \mathrm{t}, J=7.5 \mathrm{~Hz}), 8.05(1 \mathrm{H}, \mathrm{dd}, J=8.1,1.5 \mathrm{~Hz}), 8.16-8.19$ $(3 \mathrm{H}, \mathrm{m})$. Anal. calcd for $\mathrm{C}_{27} \mathrm{H}_{27} \mathrm{~N}_{3} \mathrm{O}_{4} \mathrm{~S}: \mathrm{C}, 66.24 ; \mathrm{H}, 5.56 ; \mathrm{N}, 8.58$. Found: $\mathrm{C}, 66.08$; $\mathrm{H}, 5.50 ; \mathrm{N}, 8.58$.

The following compounds $\mathbf{1 b}-\mathbf{h}$ were prepared in a manner similar to that described for $\mathbf{1 a}$.

\section{3-Methoxy-4-oxo-5-(2-oxo-2-phenylethyl)- $N$-(2-pyrrolidin-1-ylethyl)-4,5-dihydro-}

furo[3,2-c]quinoline-2-carboxamide (1b)

Yield 66\%, white crystals; mp $171{ }^{\circ} \mathrm{C}$ (recrystallized from AcOEt). ${ }^{1} \mathrm{H}$ NMR $\left(\mathrm{DMSO}_{6}\right) \delta 1.69-1.73(4 \mathrm{H}, \mathrm{m}), 2.49-2.51(4 \mathrm{H}, \mathrm{m}), 2.61(2 \mathrm{H}, \mathrm{t}, J=6.6 \mathrm{~Hz}), 3.40-3.46$ $(2 \mathrm{H}, \mathrm{m}), 4.15(3 \mathrm{H}, \mathrm{s}), 6.00(2 \mathrm{H}, \mathrm{s}), 7.43(1 \mathrm{H}, \mathrm{t}, J=8.1 \mathrm{~Hz}), 7.54(1 \mathrm{H}, \mathrm{d}, J=8.4 \mathrm{~Hz})$, 7.60-7.67 (3H, m), 7.74-7.79 $(1 \mathrm{H}, \mathrm{m}), 8.06(1 \mathrm{H}, \mathrm{t}, J=8.6 \mathrm{~Hz}), 8.15-8.19(3 \mathrm{H}, \mathrm{m})$. LC-MS: $\mathrm{m} / \mathrm{z}=474\left(\mathrm{MH}^{+}\right)$. Anal. calcd for $\mathrm{C}_{27} \mathrm{H}_{27} \mathrm{~N}_{3} \mathrm{O}_{5}: \mathrm{C}, 68.48 ; \mathrm{H}, 5.75 ; \mathrm{N}, 8.87$. 
Found: C, 68.32; H, 5.68; N, 8.97.

3-Methoxy-1-methyl-4-oxo-5-(2-oxo-2-phenylethyl)- $N$-(2-pyrrolidin-1-ylethyl)-4,5dihydro-1H-pyrrolo[3,2-c]quinoline-2-carboxamide (1c)

Yield 78\%, white crystals; mp $204{ }^{\circ} \mathrm{C}$ (recrystallized from AcOEt). ${ }^{1} \mathrm{H}$ NMR $\left(\mathrm{DMSO}_{6}\right) \delta$ 1.65-1.75 (4H, m), 2.48-2.55 (4H, m), $2.62(2 \mathrm{H}, \mathrm{t}, J=6.2 \mathrm{~Hz}), 3.39-3.45$ $(2 \mathrm{H}, \mathrm{m}), 3.97(3 \mathrm{H}, \mathrm{s}), 4.37(3 \mathrm{H}, \mathrm{s}), 5.97(2 \mathrm{H}, \mathrm{s}), 7.29-7.39(2 \mathrm{H}, \mathrm{m}), 7.45-7.50(1 \mathrm{H}, \mathrm{m})$, 7.61-7.66 (2H, m), 7.73-7.78 (1H, m), 8.16-8.18 (3H, m), $8.39(1 \mathrm{H}, \mathrm{dd}, J=8.1,1.2 \mathrm{~Hz})$. LC-MS: $\mathrm{m} / \mathrm{z}=487\left(\mathrm{MH}^{+}\right)$. Anal. calcd for $\mathrm{C}_{28} \mathrm{H}_{30} \mathrm{~N}_{4} \mathrm{O}_{4}: \mathrm{C}, 69.12 ; \mathrm{H}, 6.21 ; \mathrm{N}, 11.51$. Found: C, 69.16; H, 6.20; N, 11.59.

3-Ethoxy-1-methyl-4-oxo-5-(2-oxo-2-phenylethyl)- $N$-(2-pyrrolidin-1-ylethyl)-4,5dihydro-1H-pyrrolo[3,2-c]quinoline-2-carboxamide (1d)

Yield 18\%, white crystals; mp $217{ }^{\circ} \mathrm{C}$ (recrystallized from AcOEt/THF). ${ }^{1} \mathrm{H}$ NMR (DMSO- $\left.d_{6}\right) \delta 1.32(3 \mathrm{H}, \mathrm{t}, J=7.0 \mathrm{~Hz}), 1.65-1.75(4 \mathrm{H}, \mathrm{m}), 2.40-2.55(4 \mathrm{H}, \mathrm{m}), 2.62$ $(2 \mathrm{H}, \mathrm{t}, J=6.0 \mathrm{~Hz}), 3.05-3.47(2 \mathrm{H}, \mathrm{m}), 4.29(2 \mathrm{H}, \mathrm{q}, J=7.0 \mathrm{~Hz}), 4.39(3 \mathrm{H}, \mathrm{s}), 5.96(2 \mathrm{H}$, s), 7.29-7.39 (2H, m), $7.48(1 \mathrm{H}, \mathrm{t}, J=7.8 \mathrm{~Hz}), 7.63(2 \mathrm{H}, \mathrm{t}, J=7.7 \mathrm{~Hz}), 7.76(1 \mathrm{H}, \mathrm{t}, J=$ $7.4 \mathrm{~Hz}), 8.12-8.19(3 \mathrm{H}, \mathrm{m}), 8.38(1 \mathrm{H}, \mathrm{d}, J=8.4 \mathrm{~Hz})$. LC-MS: $\mathrm{m} / \mathrm{z}=501\left(\mathrm{MH}^{+}\right)$. Anal. calcd for $\mathrm{C}_{2} \mathrm{H}_{32} \mathrm{~N}_{4} \mathrm{O}_{4}: \mathrm{C}, 69.58 ; \mathrm{H}, 6.44 ; \mathrm{N}, 11.19$. Found: $\mathrm{C}, 69.83 ; \mathrm{H}, 6.26 ; \mathrm{N}$, 10.63 .

\section{3-Methoxy-1-methyl-4-oxo-5-(2-oxo-2-phenylethyl)- $N$-(2-piperidin-1-ylethyl)-4,5-} dihydro-1H-pyrrolo[3,2-c]quinoline-2-carboxamide (1e)

Yield 90\%, white crystals; mp $230{ }^{\circ} \mathrm{C}$ (recrystallized from THF/EtOH). ${ }^{1} \mathrm{H}$ NMR (DMSO- $\left.d_{6}\right) \delta 1.30-1.65(6 \mathrm{H}, \mathrm{m}), 2.30-2.60(6 \mathrm{H}, \mathrm{m}), 3.40-3.45(2 \mathrm{H}, \mathrm{m}), 4.01(3 \mathrm{H}$, s), $4.38(3 \mathrm{H}, \mathrm{s}), 5.97(2 \mathrm{H}, \mathrm{s}), 7.29-7.39(2 \mathrm{H}, \mathrm{m}), 7.45-7.51(1 \mathrm{H}, \mathrm{m}), 7.63(2 \mathrm{H}, \mathrm{t}, J=7.5$ $\mathrm{Hz}), 7.73-7.78(1 \mathrm{H}, \mathrm{m}), 8.11-8.19(3 \mathrm{H}, \mathrm{m}), 8.38(1 \mathrm{H}, \mathrm{dd}, J=8.4,1.2 \mathrm{~Hz}) . \quad$ LC-MS: $\mathrm{m} / \mathrm{z}=501\left(\mathrm{MH}^{+}\right)$. Anal. calcd for $\mathrm{C}_{29} \mathrm{H}_{32} \mathrm{~N}_{4} \mathrm{O}_{4} \cdot 0.2 \mathrm{H}_{2} \mathrm{O}: \mathrm{C}, 69.08 ; \mathrm{H}, 6.48 ; \mathrm{N}, 11.11$. Found: C, 69.06; H, 6.45; N, 11.09 .

\section{3-Methoxy-1-methyl- $N$-(2-morpholin-4-ylethyl)-4-oxo-5-(2-oxo-2-phenylethyl)-4,5-} dihydro-1H-pyrrolo[3,2-c]quinoline-2-carboxamide (1f)

Yield $82 \%$, white crystals; mp $228{ }^{\circ} \mathrm{C}$ (recrystallized from AcOEt/THF). ${ }^{1} \mathrm{H}$ NMR (DMSO- $\left.d_{6}\right) \delta 2.40-2.55(6 \mathrm{H}, \mathrm{m}), 3.40-3.50(2 \mathrm{H}, \mathrm{m}), 3.61(4 \mathrm{H}, \mathrm{t}, J=4.2 \mathrm{~Hz}), 4.01$ $(3 \mathrm{H}, \mathrm{s}), 4.37(3 \mathrm{H}, \mathrm{s}), 5.97(2 \mathrm{H}, \mathrm{s}), 7.29-7.40(2 \mathrm{H}, \mathrm{m}), 7.48(1 \mathrm{H}, \mathrm{t}, J=7.7 \mathrm{~Hz}), 7.64(2 \mathrm{H}$, $\mathrm{t}, J=7.4 \mathrm{~Hz}), 7.76(1 \mathrm{H}, \mathrm{t}, J=7.4 \mathrm{~Hz}), 8.12-8.19(3 \mathrm{H}, \mathrm{m}), 8.38(1 \mathrm{H}, \mathrm{d}, J=8.4 \mathrm{~Hz})$. LC-MS: $\mathrm{m} / \mathrm{z}=503\left(\mathrm{MH}^{+}\right)$. Anal. calcd for $\mathrm{C}_{28} \mathrm{H}_{30} \mathrm{~N}_{4} \mathrm{O}_{5}: \mathrm{C}, 66.92 ; \mathrm{H}, 6.02 ; \mathrm{N}, 11.15$. 
Found: C, 67.04; H, 5.93; N, 11.28.

3-Methoxy-1-methyl-4-oxo-5-(2-oxo-2-phenylethyl)- $N$-piperidin-4-yl-4,5-dihydro1H-pyrrolo[3,2-c]quinoline-2-carboxamide (1g)

Yield 85\%, white crystals; mp $206{ }^{\circ} \mathrm{C}$ (recrystallized from AcOEt/EtOH). ${ }^{1} \mathrm{H}$ NMR (DMSO- $\left.d_{6}\right) \delta$ 1.34-1.46 (2H, m), 1.78-1.84 (2H, m), 1.90-2.20 (1H, m), 2.50-2.60 $(2 \mathrm{H}, \mathrm{m}), 2.85-3.00(2 \mathrm{H}, \mathrm{m}), 3.80-3.95(1 \mathrm{H}, \mathrm{m}), 3.98(3 \mathrm{H}, \mathrm{s}), 4.32(3 \mathrm{H}, \mathrm{s}), 5.97(2 \mathrm{H}, \mathrm{s})$, 7.29-7.39 (2H, m), 7.45-7.50 (1H, m), $7.63(2 \mathrm{H}, \mathrm{t}, J=7.5 \mathrm{~Hz}), 7.76(1 \mathrm{H}, \mathrm{t}, J=7.5 \mathrm{~Hz})$, $7.86(1 \mathrm{H}, \mathrm{d}, J=7.8 \mathrm{~Hz}), 8.16-8.18(2 \mathrm{H}, \mathrm{m}), 8.37(1 \mathrm{H}, \mathrm{dd}, J=8.4,1.2 \mathrm{~Hz}) . \quad$ LC-MS: $\mathrm{m} / \mathrm{z}=473\left(\mathrm{MH}^{+}\right)$. Anal. calcd for $\mathrm{C}_{27} \mathrm{H}_{28} \mathrm{~N}_{4} \mathrm{O}_{4} \bullet 1.0 \mathrm{H}_{2} \mathrm{O}: \mathrm{C}, 66.11 ; \mathrm{H}, 6.16 ; \mathrm{N}, 11.42$. Found: C, 65.82; H, 6.05; N, 11.32.

tert-Butyl 4-(\{[3-methoxy-5-(4-methoxybenzyl)-1-methyl-4-oxo-4,5-dihydro-1Hpyrrolo[3,2-c]quinolin-2-yl]carbonyl\}amino)piperidine-1-carboxylate (1h)

Yield 93\%, white powder. ${ }^{1} \mathrm{H}$ NMR $\left(\mathrm{DMSO}_{6}\right) \delta 1.33-1.58(11 \mathrm{H}, \mathrm{m})$, 1.76-1.94 (2H, m), 2.83-3.09 (2H, m), $3.69(3 \mathrm{H}, \mathrm{s}), 3.79-3.95(2 \mathrm{H}, \mathrm{m}), 3.95-4.11(4 \mathrm{H}$, m), $4.27(3 \mathrm{H}, \mathrm{s}), 5.52(2 \mathrm{H}, \mathrm{br} \mathrm{s}), 6.81-6.91(2 \mathrm{H}, \mathrm{m}), 7.14(2 \mathrm{H}, \mathrm{d}, J=8.7 \mathrm{~Hz}), 7.22-7.32$ $(1 \mathrm{H}, \mathrm{m}), 7.38-7.53(2 \mathrm{H}, \mathrm{m}), 7.97(1 \mathrm{H}, \mathrm{d}, J=7.9 \mathrm{~Hz}), 8.33(1 \mathrm{H}, \mathrm{d}, J=7.9 \mathrm{~Hz})$. LC-MS: $\mathrm{m} / \mathrm{z}=575\left(\mathrm{MH}^{+}\right)$.

3-Methoxy-5-(4-methoxybenzyl)-1-methyl-4-oxo- $N$-piperidin-4-yl-4,5-dihydro- $1 H$ pyrrolo[3,2-c]quinoline-2-carboxamide hydrochloride (1i)

$4 \mathrm{M} \mathrm{HCl}$ in AcOEt solution $(5 \mathrm{~mL})$ was added to a solution of $\mathbf{1 h}(500 \mathrm{mg}, 0.87$ mmol) in AcOEt $(15 \mathrm{~mL})$, and the mixture was stirred at room temperature for $4 \mathrm{~h}$. The precipitate was collected by filtration, washed with diethyl ether, and dried in vacuo to give the title compound (440 mg, 99\%) as a pale pink powder. ${ }^{1} \mathrm{H} \mathrm{NMR}$ $\left(\mathrm{DMSO}_{6}\right) \delta 1.78(2 \mathrm{H}, \mathrm{q}, J=10.3 \mathrm{~Hz}), 2.05(2 \mathrm{H}, \mathrm{d}, J=10.8 \mathrm{~Hz}), 3.06(2 \mathrm{H}, \mathrm{t}, J=10.7$ $\mathrm{Hz}), 3.26-3.33(2 \mathrm{H}, \mathrm{m}), 3.63(3 \mathrm{H}, \mathrm{s}), 4.02(3 \mathrm{H}, \mathrm{s}), 4.09-4.13(1 \mathrm{H}, \mathrm{m}), 4.24(3 \mathrm{H}, \mathrm{s})$, 5.40-5.60 (2H, m), $6.86(2 \mathrm{H}, \mathrm{d}, J=8.7 \mathrm{~Hz}), 7.14(2 \mathrm{H}, \mathrm{d}, J=8.7 \mathrm{~Hz}), 7.25-7.30(1 \mathrm{H}, \mathrm{m})$, 7.42-7.49 (2H, m), $8.15(1 \mathrm{H}, \mathrm{d}, J=7.5 \mathrm{~Hz}), 8.33(1 \mathrm{H}, \mathrm{d}, J=7.8 \mathrm{~Hz}), 8.60-8.90(2 \mathrm{H}, \mathrm{m})$. LC-MS: $\mathrm{m} / \mathrm{z}=475\left(\mathrm{MH}^{+}-\mathrm{HCl}\right)$.

$N$-[1-(2-Hydroxyethyl)piperidin-4-yl]-3-methoxy-5-(4-methoxybenzyl)-1-methyl-4oxo-4,5-dihydro-1H-pyrrolo[3,2-c]quinoline-2-carboxamide (10)

A mixture of $1 \mathbf{i}(9.39 \mathrm{~g}, 18.4 \mathrm{mmol}), 2$-bromoethanol $(3.25 \mathrm{~mL}, 45.6 \mathrm{mmol})$ and $\mathrm{K}_{2} \mathrm{CO}_{3}(10.2 \mathrm{~g}, 73.6 \mathrm{mmol})$ in DMF $(250 \mathrm{~mL})$ was stirred at $80{ }^{\circ} \mathrm{C}$ for $16 \mathrm{~h}$. After 
cooling, the reaction mixture was concentrated in vacuo and the residue was partitioned between saturated $\mathrm{NaHCO}_{3}$ aq. and AcOEt. The aqueous layer was separated and extracted with AcOEt/THF. The combined extracts were washed with brine, dried over $\mathrm{MgSO}_{4}$, and concentrated in vacuo. The residual precipitate was collected by filtration, and washed with hexane/AcOEt to give the title compound $(7.75 \mathrm{~g}, 81 \%)$ as white powder. ${ }^{1} \mathrm{H}$ NMR (DMSO- $\left.d_{6}\right) \delta 1.43-1.71(2 \mathrm{H}, \mathrm{m}), 1.77-1.94(2 \mathrm{H}, \mathrm{m})$, 2.08-2.26 (2H, m), $2.40(2 \mathrm{H}, \mathrm{t}, J=6.3 \mathrm{~Hz}), 2.70-2.86(2 \mathrm{H}, \mathrm{m}), 3.50(2 \mathrm{H}, \mathrm{q}, J=6.2 \mathrm{~Hz})$, $3.69(3 \mathrm{H}, \mathrm{s}), 3.73-3.94(1 \mathrm{H}, \mathrm{m}), 4.04(3 \mathrm{H}, \mathrm{s}), 4.29(3 \mathrm{H}, \mathrm{s}), 4.37(1 \mathrm{H}, \mathrm{t}, J=5.4 \mathrm{~Hz}), 5.52$ (2H, br s), 6.78-6.91 (2H, m), $7.14(2 \mathrm{H}, \mathrm{d}, J=8.7 \mathrm{~Hz}), 7.22-7.33(1 \mathrm{H}, \mathrm{m}), 7.38-7.53$ $(2 \mathrm{H}, \mathrm{m}), 7.90(1 \mathrm{H}, \mathrm{d}, J=7.7 \mathrm{~Hz}), 8.33(1 \mathrm{H}, \mathrm{d}, J=7.9 \mathrm{~Hz}) . \quad$ LC-MS: m/z $=519\left(\mathrm{MH}^{+}\right)$.

\section{2-(4-\{[(3-Methoxy-1-methyl-4-oxo-4,5-dihydro-1H-pyrrolo[3,2-c]quinolin-2-yl) carbonyl]amino\}piperidin-1-yl)ethyl acetate (11)}

A mixture of 10 (498 mg, $0.959 \mathrm{mmol})$, anisole $(0.4 \mathrm{~mL}, 3.68 \mathrm{mmol})$, TfOH (1 $\mathrm{mL})$, and TFA $(4 \mathrm{~mL})$ was stirred at $80{ }^{\circ} \mathrm{C}$ for $1 \mathrm{~h}$. After the mixture was concentrated in vacuo, the residue was quenched with aqueous $\mathrm{NaHCO}_{3}$ solution and diluted with AcOEt $/ \mathrm{THF}=1 / 1$ solution $(40 \mathrm{~mL})$. The organic layer was separated and the aqueous layer was extracted with $\mathrm{AcOEt} / \mathrm{THF}=1 / 1$ solution. $\mathrm{NaCl}(15 \mathrm{~g})$ was added to the aqueous layer and was extracted with THF. The combined organic layer was dried over $\mathrm{MgSO}_{4}$, and concentrated in vacuo. $\mathrm{Et}_{3} \mathrm{~N}(0.4 \mathrm{~mL}, 2.87 \mathrm{mmol})$ and acetyl chloride $(164 \mu \mathrm{L}, 2.31 \mathrm{mmol})$ were added at $0{ }^{\circ} \mathrm{C}$ to a suspension of the residue in THF $(10 \mathrm{~mL})$. The mixture was stirred at $0{ }^{\circ} \mathrm{C}$ for $2 \mathrm{~h}, \mathrm{Et}_{3} \mathrm{~N}(0.4 \mathrm{~mL}, 2.87 \mathrm{mmol})$ and acetyl chloride $(164 \mu \mathrm{L}, 2.31 \mathrm{mmol})$ were further added. After stirring at $0{ }^{\circ} \mathrm{C}$ for $2 \mathrm{~h}$, the mixture was quenched with aqueous $\mathrm{NaHCO}_{3}$ solution $(30 \mathrm{~mL})$ and extracted with AcOEt. The organic layer was washed with brine, dried over $\mathrm{MgSO}_{4}$, and concentrated in vacuo. The residue was purified by silica gel column chromatography (hexane $/ \mathrm{AcOEt}=1 / 2$ to $\mathrm{AcOEt} / \mathrm{MeOH}=4 / 1)$ to give the title compound $(221 \mathrm{mg}, 52 \%$ ) as a pale yellow powder. ${ }^{1} \mathrm{H}$ NMR (DMSO- $\left.d_{6}\right) \delta 1.46-1.66(2 \mathrm{H}, \mathrm{m}), 1.76-1.92(2 \mathrm{H}, \mathrm{m})$, $2.02(3 \mathrm{H}, \mathrm{s}), 2.13-2.30(2 \mathrm{H}, \mathrm{m}), 2.55(2 \mathrm{H}, \mathrm{t}, J=5.9 \mathrm{~Hz}), 2.69-2.86(2 \mathrm{H}, \mathrm{m}), 3.70-3.92$ $(1 \mathrm{H}, \mathrm{m}), 4.03(3 \mathrm{H}, \mathrm{s}), 4.11(2 \mathrm{H}, \mathrm{t}, J=5.9 \mathrm{~Hz}), 4.29(3 \mathrm{H}, \mathrm{s}), 7.15-7.28(1 \mathrm{H}, \mathrm{m})$, 7.35-7.52 (2H, m), $7.85(1 \mathrm{H}, \mathrm{d}, J=7.7 \mathrm{~Hz}), 8.24(1 \mathrm{H}, \mathrm{d}, J=8.1 \mathrm{~Hz}), 11.33(1 \mathrm{H}, \mathrm{s})$. LC-MS: $\mathrm{m} / \mathrm{z}=441\left(\mathrm{MH}^{+}\right)$.

\section{$N$-[1-(2-Hydroxyethyl)piperidin-4-yl]-3-methoxy-1-methyl-4-oxo-5-(2-oxo-2-phenyl ethyl)-4,5-dihydro-1H-pyrrolo[3,2-c]quinoline-2-carboxamide (12a)}

A mixture of 1 g (200 mg, $0.399 \mathrm{mmol})$, 2-bromoethanol (42.5 $\mu \mathrm{L}, 0.599 \mathrm{mmol})$, 
$\mathrm{K}_{2} \mathrm{CO}_{3}(248 \mathrm{mg}, 1.80 \mathrm{mmol})$, and DMF $(5 \mathrm{~mL})$ was stirred at $100{ }^{\circ} \mathrm{C}$ for $15 \mathrm{~h}$. The reaction mixture was diluted with water, and extracted with AcOEt. The extract was washed with brine, dried over $\mathrm{MgSO}_{4}$, and concentrated in vacuo. The residue was purified by basic silica gel column chromatography (AcOEt) followed by crystallization from $\mathrm{AcOEt} / \mathrm{EtOH}$ to give the title compound $(68.0 \mathrm{mg}, 33 \%)$ as white crystals; $\mathrm{mp}$ $201{ }^{\circ} \mathrm{C} . \quad{ }^{1} \mathrm{H}$ NMR (DMSO- $\left.d_{6}\right) \delta 1.51-1.62(2 \mathrm{H}, \mathrm{m}), 1.75-1.90(2 \mathrm{H}, \mathrm{m}), 2.18(2 \mathrm{H}, \mathrm{t}, J=$ $10.5 \mathrm{~Hz}), 2.40(2 \mathrm{H}, \mathrm{t}, J=5.9 \mathrm{~Hz}), 2.70-2.85(2 \mathrm{H}, \mathrm{m}), 3.47-3.52(2 \mathrm{H}, \mathrm{m}), 3.75-3.90(1 \mathrm{H}$, m), $3.98(3 \mathrm{H}, \mathrm{s}), 4.32-4.38(4 \mathrm{H}, \mathrm{m}), 5.97(2 \mathrm{H}, \mathrm{s}), 7.29-7.39(2 \mathrm{H}, \mathrm{m}), 7.47(1 \mathrm{H}, \mathrm{t}, J=7.6$ $\mathrm{Hz}), 7.63(2 \mathrm{H}, \mathrm{t}, J=7.6 \mathrm{~Hz}), 7.76(1 \mathrm{H}, \mathrm{t}, J=7.1 \mathrm{~Hz}), 7.87(1 \mathrm{H}, \mathrm{d}, J=7.5 \mathrm{~Hz}), 8.17(2 \mathrm{H}$, d, $J=7.6 \mathrm{~Hz}), 8.37(1 \mathrm{H}, \mathrm{d}, J=8.4 \mathrm{~Hz}) . \quad$ LC-MS: $\mathrm{m} / \mathrm{z}=517\left(\mathrm{MH}^{+}\right)$. Anal. calcd for $\mathrm{C}_{29} \mathrm{H}_{32} \mathrm{~N}_{4} \mathrm{O}_{5}$ : C, 67.43; H, 6.24; N, 10.85. Found: C, 67.28; H, 6.20; N, 10.79.

\section{$N$-[1-(Hydroxyacetyl)piperidin-4-yl]-3-methoxy-1-methyl-4-oxo-5-(2-oxo-2-phenyl ethyl)-4,5-dihydro-1H-pyrrolo[3,2-c]quinoline-2-carboxamide (12b)}

Acetoxyacetyl chloride $(47.3 \mu \mathrm{L}, 0.440 \mathrm{mmol})$ was added to a mixture of $\mathbf{1 g}$ (200 $\mathrm{mg}, 0.423 \mathrm{mmol}), \mathrm{Et}_{3} \mathrm{~N}(122 \mu \mathrm{L}, 0.880 \mathrm{mmol})$, and $\mathrm{THF}(10 \mathrm{~mL})$ at $0{ }^{\circ} \mathrm{C}$ and the mixture was stirred at room temperature for $15 \mathrm{~h}$. The reaction mixture was diluted with AcOEt, washed with water and brine, dried over $\mathrm{MgSO}_{4}$, and concentrated in vacuo. The residue was purified by basic silica gel column chromatography (AcOEt) followed by crystallization from AcOEt/THF to give 2-[4-(\{[3-methoxy-1-methyl-4-oxo-5-(2-oxo-2-phenylethyl)-4,5-dihydro-1H-pyrrolo[3, 2-c] quinolin-2-yl]carbonyl $\}$ amino)piperidin-1-yl]-2-oxoethyl acetate (171 $\mathrm{mg}, 75 \%)$ as a white powder. The compound obtained was dissolved in $8 \mathrm{M} \mathrm{NaOH}$ aq. $(1 \mathrm{~mL})$, THF $(2 \mathrm{~mL})$, and EtOH $(7 \mathrm{~mL})$. After stirring at room temperature for $2 \mathrm{~h}$, the reaction mixture was diluted with water, acidified with $6 \mathrm{M} \mathrm{HCl}$ aq., and extracted with AcOEt. The extract was washed with brine, dried over $\mathrm{MgSO}_{4}$, and concentrated in vacuo. The residue was purified by basic silica gel column chromatography (AcOEt) followed by crystallization from AcOEt/THF to give the title compound (59.2 mg, 51\%) as white crystals; mp $223{ }^{\circ} \mathrm{C} .{ }^{1} \mathrm{H}$ NMR (DMSO- $\left.d_{6}\right) \delta 1.35-1.65(2 \mathrm{H}, \mathrm{m}), 1.80-2.00$ $(2 \mathrm{H}, \mathrm{m}), 2.85-3.00(1 \mathrm{H}, \mathrm{m}), 3.05-3.25(1 \mathrm{H}, \mathrm{m}), 3.60-3.75(1 \mathrm{H}, \mathrm{m}), 3.97(3 \mathrm{H}, \mathrm{s})$, 4.00-4.30 (4H, m), $4.31(3 \mathrm{H}, \mathrm{s}), 4.51(1 \mathrm{H}, \mathrm{t}, J=5.3 \mathrm{~Hz}), 5.97(2 \mathrm{H}, \mathrm{s}), 7.29-7.39(2 \mathrm{H}, \mathrm{m})$, $7.48(1 \mathrm{H}, \mathrm{t}, J=7.6 \mathrm{~Hz}), 7.63(2 \mathrm{H}, \mathrm{t}, J=7.6 \mathrm{~Hz}), 7.76(1 \mathrm{H}, \mathrm{t}, J=7.4 \mathrm{~Hz}), 7.95(1 \mathrm{H}, \mathrm{d}, J$ $=8.4 \mathrm{~Hz}), 8.17(2 \mathrm{H}, \mathrm{d}, J=7.6 \mathrm{~Hz}), 8.37(1 \mathrm{H}, \mathrm{d}, J=8.1 \mathrm{~Hz}) . \quad$ LC-MS: $\mathrm{m} / \mathrm{z}=531$ $\left(\mathrm{MH}^{+}\right)$. Anal. calcd for $\mathrm{C}_{29} \mathrm{H}_{30} \mathrm{~N}_{4} \mathrm{O}_{6}: \mathrm{C}, 65.65 ; \mathrm{H}, 5.70 ; \mathrm{N}, 10.56$. Found: $\mathrm{C}, 65.60 ; \mathrm{H}$, 5.62; N, 10.46 . 


\section{$N$-[1-(2-Hydroxyethyl)piperidin-4-yl]-3-methoxy-1-methyl-4-oxo-5-(2-oxobutyl)-}

\section{4,5-dihydro-1H-pyrrolo[3,2-c]quinoline-2-carboxamide (12c)}

tert-BuONa (89.3 mg, $0.929 \mathrm{mmol})$ was added to a suspension of $\mathbf{1 1}(299 \mathrm{mg}$, $0.679 \mathrm{mmol})$ in DME $(2.4 \mathrm{~mL}) / \mathrm{DMF}(0.6 \mathrm{~mL})$ and the mixture was stirred at $0{ }^{\circ} \mathrm{C}$ for $30 \mathrm{~min}$. $\operatorname{LiBr}(142 \mathrm{mg}, 1.64 \mathrm{mmol})$ was added, and the mixture was stirred at room temperature for $10 \mathrm{~min}$. 1-Bromo-2-butanone $(76.6 \mu \mathrm{L}, 0.750 \mathrm{mmol})$ was added and the mixture was stirred at room temperature for $65 \mathrm{~h}$. After addition of $1 \mathrm{M} \mathrm{NaOH}$ aq. $(1.5 \mathrm{~mL})$ and $\mathrm{MeOH}(1 \mathrm{~mL})$, the mixture was stirred at room temperature for $30 \mathrm{~min}$, and concentrated in vacuo. The residue was partitioned between AcOEt/THF $=3 / 1$ solution $(20 \mathrm{~mL})$ and aq. $\mathrm{NaHCO}_{3}$ solution $(20 \mathrm{~mL})$. The organic layer was separated, and the aq. layer was extracted with $\mathrm{AcOEt} / \mathrm{THF}=3 / 1$ solution $(20 \mathrm{~mL} \times 3)$. The organic layer was combined, washed with brine $(10 \mathrm{~mL})$, dried over $\mathrm{MgSO}_{4}$, and concentrated in vacuo. The residue was suspended with AcOEt (10 mL) and DMF (1 $\mathrm{mL}$ ) at $60{ }^{\circ} \mathrm{C}$, and insoluble material was removed by filtration. The filtrate was concentrated in vacuo, and purified by basic silica gel column chromatography (hexane/AcOEt $=1 / 2$ to $\mathrm{AcOEt} / \mathrm{MeOH}=9 / 1$ ). Crystallization from IPE/AcOEt gave the title compound $(48.7 \mathrm{mg}, 15 \%)$ as white crystals; mp $191{ }^{\circ} \mathrm{C} .{ }^{1} \mathrm{H} \mathrm{NMR}$ $\left(\mathrm{DMSO}_{-} d_{6}\right) \delta 1.01(3 \mathrm{H}, \mathrm{t}, J=7.3 \mathrm{~Hz}), 1.45-1.67(2 \mathrm{H}, \mathrm{m}), 1.75-1.91(2 \mathrm{H}, \mathrm{m}), 2.08-2.25$ $(2 \mathrm{H}, \mathrm{m}), 2.39(2 \mathrm{H}, \mathrm{t}, J=6.3 \mathrm{~Hz}), 2.70(2 \mathrm{H}, \mathrm{q}, J=7.2 \mathrm{~Hz}), 2.70-2.85(2 \mathrm{H}, \mathrm{m}), 3.42-3.57$ $(2 \mathrm{H}, \mathrm{m}), 3.71-3.91(1 \mathrm{H}, \mathrm{m}), 3.98(3 \mathrm{H}, \mathrm{s}), 4.29(3 \mathrm{H}, \mathrm{s}), 4.38(1 \mathrm{H}, \mathrm{t}, J=5.3 \mathrm{~Hz}), 5.29(2 \mathrm{H}$, s), 7.24-7.37 (2H, m), 7.43-7.56 (1H, m), $7.87(1 \mathrm{H}, \mathrm{d}, J=7.9 \mathrm{~Hz}), 8.28-8.40(1 \mathrm{H}, \mathrm{m})$. LC-MS: $\mathrm{m} / \mathrm{z}=469\left(\mathrm{MH}^{+}\right)$. Anal. calcd for $\mathrm{C}_{25} \mathrm{H}_{32} \mathrm{~N}_{4} \mathrm{O}_{5}: \mathrm{C}, 64.09 ; \mathrm{H}, 6.88 ; \mathrm{N}, 11.96$. Found: C, 63.73; H, 6.83; N, 11.81 .

\section{$N$-[1-(2-Hydroxyethyl)piperidin-4-yl]-3-methoxy-1-methyl-4-oxo-5-(2-phenylethyl)-}

\section{4,5-dihydro-1H-pyrrolo[3,2-c]quinoline-2-carboxamide (12d)}

In a similar manner to the preparation of 12c, the title compound $(8.2 \mathrm{mg}, 2.4 \%)$ was obtained as beige crystals from 11 (299 mg, $0.678 \mathrm{mmol}$ ); mp $163{ }^{\circ} \mathrm{C}$ (crystallized from IPE/AcOEt). ${ }^{1} \mathrm{H}$ NMR (DMSO- $\left.d_{6}\right) \delta 1.46-1.67(2 \mathrm{H}, \mathrm{m}), 1.76-1.91(2 \mathrm{H}, \mathrm{m})$, 2.09-2.25 (2H, m), $2.40(2 \mathrm{H}, \mathrm{t}, J=6.3 \mathrm{~Hz}), 2.67-2.84(2 \mathrm{H}, \mathrm{m}), 2.86-2.99(2 \mathrm{H}, \mathrm{m})$, 3.44-3.55 (2H, m), 3.70-3.91 (1H, m), $3.98(3 \mathrm{H}, \mathrm{s}), 4.28(3 \mathrm{H}, \mathrm{s}), 4.37(1 \mathrm{H}, \mathrm{t}, J=5.4 \mathrm{~Hz})$, 4.45-4.58 (2H, m), 7.17-7.28 (1H, m), 7.28-7.40 (5H, m), 7.56-7.67 (1H, m), 7.69-7.78 $(1 \mathrm{H}, \mathrm{m}), 7.86(1 \mathrm{H}, \mathrm{d}, J=7.7 \mathrm{~Hz}), 8.36(1 \mathrm{H}, \mathrm{dd}, J=8.4,1.2 \mathrm{~Hz}) . \quad$ LC-MS: $\mathrm{m} / \mathrm{z}=503$ $\left(\mathrm{MH}^{+}\right)$. Anal. calcd for $\mathrm{C}_{29} \mathrm{H}_{34} \mathrm{~N}_{4} \mathrm{O}_{4} \bullet 0.5 \mathrm{H}_{2} \mathrm{O}: \mathrm{C}, 68.08 ; \mathrm{H}, 6.90 ; \mathrm{N}, 10.95$. Found: $\mathrm{C}$, $67.77 ; \mathrm{H}, 6.76 ; \mathrm{N}, 10.72$. 


\section{Experimental section of chapter II}

\section{Methyl (2Z)-3-aminopent-2-enoate (14a)}

A mixture of 13a (75.0 g, $576 \mathrm{mmol}), \mathrm{NH}_{4} \mathrm{OAc}(222 \mathrm{~g}, 2.88 \mathrm{mmol})$ and $\mathrm{MeOH}$ $(750 \mathrm{~mL})$ was stirred at room temperature for 3 days. The mixture was concentrated in vacuo. The residue was diluted with water $(500 \mathrm{~mL})$ and extracted with AcOEt. The extract was washed with brine, dried over $\mathrm{MgSO}_{4}$, concentrated in vacuo, and dried to give the title compound $(68.5 \mathrm{~g}, 92 \%)$ as a pale yellow oil. ${ }^{1} \mathrm{H}$ NMR (DMSO- $\left.d_{6}\right) \delta 1.06$ $(3 \mathrm{H}, \mathrm{t}, J=7.6 \mathrm{~Hz}), 2.09$ (2H, q, $J=7.6 \mathrm{~Hz}), 3.49(3 \mathrm{H}, \mathrm{s}), 4.34(1 \mathrm{H}, \mathrm{s}), 6.94(1 \mathrm{H}, \mathrm{s})$, $7.72(1 \mathrm{H}$, br s).

\section{Ethyl 2-aminocyclohex-1-ene-1-carboxylate (14b)}

In the same manner as in the preparation of 14a, the title compound $(32.3 \mathrm{~g}, 60 \%)$ was obtained as a white solid from $13 b$ (53.9 g, $0.317 \mathrm{~mol}) .{ }^{1} \mathrm{H}$ NMR (DMSO- $\left.d_{6}\right) \delta$ $1.16(3 \mathrm{H}, \mathrm{t}, J=7.1 \mathrm{~Hz}), 1.45-1.59(4 \mathrm{H}, \mathrm{m}), 2.09-2.21(4 \mathrm{H}, \mathrm{m}), 4.00(2 \mathrm{H}, \mathrm{q}, J=7.1 \mathrm{~Hz})$, $7.09(2 \mathrm{H}$, br s).

\section{Ethyl 6-ethyl-4-hydroxy-2-oxo-1,2-dihydropyridine-3-carboxylate (15a)}

A mixture of 14a (100 g, $774 \mathrm{mmol})$, diethyl malonate (130 mL, $856 \mathrm{mmol}), 20 \%$ solution of NaOEt in EtOH (290 g, $852 \mathrm{mmol})$, EtOH (400 mL), xylene (800 mL) was stirred at $120{ }^{\circ} \mathrm{C}$ for $2 \mathrm{~h}$, at $150{ }^{\circ} \mathrm{C}$ for $17 \mathrm{~h}$ with a Dean-Stark trap. The precipitate was collected by filtration and washed with hexane. The filtered material was dissolved in water $(800 \mathrm{~mL})$ and filtered. The filtrate was acidified with $5 \mathrm{M} \mathrm{HCl}$ aq. at $0{ }^{\circ} \mathrm{C}$. The precipitate was collected by filtration, successively washed with water and hexane / IPE to give the title compound $(75.4 \mathrm{~g}, 46 \%)$ as a pale yellow powder. ${ }^{1} \mathrm{H}$ NMR (DMSO- $d_{6}$ ) $\delta 1.12(3 \mathrm{H}, \mathrm{t}, J=7.6 \mathrm{~Hz}), 1.26(3 \mathrm{H}, \mathrm{t}, J=7.1 \mathrm{~Hz}), 2.42(2 \mathrm{H}, \mathrm{q}, J=7.6 \mathrm{~Hz}), 4.25(2 \mathrm{H}, \mathrm{q}$, $J=7.1 \mathrm{~Hz}), 5.79(1 \mathrm{H}, \mathrm{s}), 11.37(1 \mathrm{H}, \mathrm{br} \mathrm{s}), 12.56(1 \mathrm{H}, \mathrm{s})$.

\section{Ethyl 4-hydroxy-2-oxo-1,2,5,6,7,8-hexahydroquinoline-3-carboxylate (15b)}

In the same manner as in the preparation of 15a, the title compound $(24.4 \mathrm{~g}, 58 \%)$ was obtained as a yellow solid from $14 \mathrm{~b}(30.0 \mathrm{~g}, 0.177 \mathrm{~mol}) .{ }^{1} \mathrm{H}$ NMR (DMSO- $\left.d_{6}\right) \delta$ $1.28(3 \mathrm{H}, \mathrm{t}, J=7.1 \mathrm{~Hz}), 1.57-1.73(4 \mathrm{H}, \mathrm{m}), 2.24-2.35(2 \mathrm{H}, \mathrm{m}), 2.41-2.48(2 \mathrm{H}, \mathrm{m}), 4.30$ $(2 \mathrm{H}, \mathrm{q}, J=7.1 \mathrm{~Hz}), 11.19(1 \mathrm{H}, \mathrm{s}), 13.49(1 \mathrm{H}, \mathrm{s})$.

\section{Ethyl 4-chloro-6-ethyl-2-oxo-1,2-dihydropyridine-3-carboxylate (16a)}

A mixture of 15a $(15.0 \mathrm{~g}, 71.0 \mathrm{mmol})$ and $\mathrm{POCl}_{3}(19.9 \mathrm{~mL}, 213 \mathrm{mmol})$ was 
stirred at $80^{\circ} \mathrm{C}$ for $30 \mathrm{~min}$. The mixture was concentrated in vacuo and ice water was added to the residue at $0{ }^{\circ} \mathrm{C}$. The resulting solid was collected by filtration and washed with water and AcOEt to give the title compound $(9.80 \mathrm{~g}, 60 \%)$ as a white solid. ${ }^{1} \mathrm{H}$ NMR (DMSO-d $\left.d_{6}\right) \delta 1.15(3 \mathrm{H}, \mathrm{t}, J=7.5 \mathrm{~Hz}), 1.26(3 \mathrm{H}, \mathrm{t}, J=7.1 \mathrm{~Hz}), 2.44-2.55(2 \mathrm{H}, \mathrm{m})$, $4.25(2 \mathrm{H}, \mathrm{q}, J=7.1 \mathrm{~Hz}), 6.26(1 \mathrm{H}, \mathrm{s}), 12.28(1 \mathrm{H}, \mathrm{s})$.

\section{Ethyl 4-chloro-2-oxo-1,2,5,6,7,8-hexahydroquinoline-3-carboxylate (16b)}

A mixture of $\mathbf{1 5 b}(26.0 \mathrm{~g}, 110 \mathrm{mmol})$ and $\mathrm{POCl}_{3}(51.3 \mathrm{~mL}, 552 \mathrm{mmol})$ was stirred at $130{ }^{\circ} \mathrm{C}$ for $1.5 \mathrm{~h}$. After cooling, the reaction mixture was concentrated in vacuo and ice was added to the residue. The mixture was neutralized with saturated $\mathrm{NaHCO}_{3}$ aq. and extracted with AcOEt. The extract was washed with saturated $\mathrm{NaHCO}_{3}$ aq. water and brine, dried over $\mathrm{MgSO}_{4}$, and concentrated in vacuo. The residual solid was collected by filtration and washed with hexane / AcOEt to give the title compound (4.65 g, $17 \%)$ as a white solid. ${ }^{1} \mathrm{H}$ NMR (DMSO- $\left.d_{6}\right) \delta 1.25(3 \mathrm{H}, \mathrm{t}, J=7.1 \mathrm{~Hz}), 1.61-1.74(4 \mathrm{H}$, m), 2.37-2.45 (2H, m), 2.51-2.57 (2H, m), $4.24(2 \mathrm{H}, \mathrm{q}, J=7.1 \mathrm{~Hz}), 12.09(1 \mathrm{H}, \mathrm{s})$.

\section{Ethyl 4-chloro-6-methyl-2-oxo-1,2-dihydropyridine-3-carboxylate (16c)}

A mixture of $15 \mathrm{c}(3.00 \mathrm{~g}, 15.2 \mathrm{mmol}), \mathrm{POCl}_{3}(7.75 \mathrm{~mL}, 83.3 \mathrm{mmol})$, and benzyltriethylammonium chloride $(13.8 \mathrm{~g}, 60.8 \mathrm{mmol})$ in $\mathrm{MeCN}(60 \mathrm{~mL})$ was stirred at $40{ }^{\circ} \mathrm{C}$ for $30 \mathrm{~min}$ and at reflux for $30 \mathrm{~min}$. After cooling, the reaction mixture was concentrated in vacuo, water was added to the residue, and the mixture was extracted with AcOEt. The extract was washed with brine, dried over $\mathrm{MgSO}_{4}$, and concentrated in vacuo. The residual solid was collected and washed with hexane / AcOEt to give the title compound $(1.45 \mathrm{~g}, 44 \%)$ as a white powder. ${ }^{1} \mathrm{H}$ NMR (DMSO- $\left.d_{6}\right) \delta 1.26(3 \mathrm{H}, \mathrm{t}, J=$ $7.0 \mathrm{~Hz}), 2.20(3 \mathrm{H}, \mathrm{s}), 4.25(2 \mathrm{H}, \mathrm{q}, J=7.0 \mathrm{~Hz}), 6.26(1 \mathrm{H}, \mathrm{s}), 12.29(1 \mathrm{H}, \mathrm{s})$.

\section{Ethyl 4-chloro-6-ethyl-2-oxo-1-(2-oxo-2-phenylethyl)-1,2-dihydropyridine-3- carboxylate (17a)}

A mixture of 16a $(9.50 \mathrm{~g}, 41.4 \mathrm{mmol}), \mathrm{K}_{2} \mathrm{CO}_{3}(13.7 \mathrm{~g}, 99.2 \mathrm{mmol})$, phenacyl bromide $(9.88 \mathrm{~g}, 49.6 \mathrm{mmol})$ and DMF $(100 \mathrm{~mL})$ was stirred at room temperature for 15 $\mathrm{h}$. The reaction mixture was diluted with water and extracted with AcOEt. The extract was washed with brine, dried over $\mathrm{MgSO}_{4}$, and concentrated in vacuo. The residue was purified by basic silica gel column chromatography (hexane/AcOEt $=9 / 1$ to $3 / 7$ ) to give the title compound $(1.00 \mathrm{~g}, 7 \%)$ as a white powder. ${ }^{1} \mathrm{H}$ NMR (DMSO- $\left.d_{6}\right) \delta 1.14(3 \mathrm{H}, \mathrm{t}$, $J=7.4 \mathrm{~Hz}), 1.24(3 \mathrm{H}, \mathrm{t}, J=7.1 \mathrm{~Hz}), 2.62(2 \mathrm{H}, \mathrm{q}, J=7.4 \mathrm{~Hz}), 4.25(2 \mathrm{H}, \mathrm{q}, J=7.1 \mathrm{~Hz})$, $5.61(2 \mathrm{H}, \mathrm{s}), 6.44(1 \mathrm{H}, \mathrm{s}), 7.54-7.66(2 \mathrm{H}, \mathrm{m}), 7.70-7.79(1 \mathrm{H}, \mathrm{m}), 8.05-8.13(2 \mathrm{H}, \mathrm{m})$. 
Ethyl 4-chloro-2-oxo-1-(2-oxo-2-phenylethyl)-1,2,5,6,7,8-hexahydroquinoline3-carboxylate (17b)

Compound 16b (3.00 g, $11.7 \mathrm{mmol})$ was added to a suspension of $\mathrm{NaH}(60 \%$ in oil, $516 \mathrm{mg}, 12.9 \mathrm{mmol})$ in DMA (30 mL) and the mixture was stirred at room temperature for $30 \mathrm{~min}$. Phenacyl bromide (2.57 $\mathrm{g}, 12.9 \mathrm{mmol})$ was added, and the mixture was stirred at room temperature for $15 \mathrm{~h}$. The mixture was diluted water, extracted with AcOEt, and washed with water and brine. The organic layer was dried over $\mathrm{MgSO}_{4}$, and concentrated in vacuo. The residue was purified by basic silica gel column chromatography (hexane/AcOEt $=9 / 1$ to AcOEt) to give the title compound $(710 \mathrm{mg}, 16 \%)$ as a white powder. ${ }^{1} \mathrm{H}$ NMR (DMSO- $\left.d_{6}\right) \delta 1.25(3 \mathrm{H}, \mathrm{t}, J=7.1 \mathrm{~Hz})$, $1.60-1.80(4 \mathrm{H}, \mathrm{m}), 2.50-2.65(4 \mathrm{H}, \mathrm{m}), 4.26(2 \mathrm{H}, \mathrm{q}, J=7.1 \mathrm{~Hz}), 5.66(2 \mathrm{H}, \mathrm{s}), 7.61(2 \mathrm{H}, \mathrm{t}$, $J=7.4 \mathrm{~Hz}), 7.74(1 \mathrm{H}, \mathrm{t}, J=7.4 \mathrm{~Hz}), 8.09(2 \mathrm{H}, \mathrm{d}, J=7.4 \mathrm{~Hz})$.

\section{Ethyl 4-chloro-6-methyl-2-oxo-1-(2-oxo-2-phenylethyl)-1,2-dihydropyridine-3- carboxylate (17c)}

In the same manner as in the preparation of 17a, the title compound (3.18 g, 23\%) was obtained as a white powder from 16c (9.00 g, $41.7 \mathrm{mmol}) .{ }^{1} \mathrm{H}$ NMR (DMSO- $\left.d_{6}\right) \delta$ $1.25(3 \mathrm{H}, \mathrm{t}, J=7.0 \mathrm{~Hz}), 2.30(3 \mathrm{H}, \mathrm{s}), 4.25(2 \mathrm{H}, \mathrm{q}, J=7.0 \mathrm{~Hz}), 5.63(2 \mathrm{H}, \mathrm{s}), 6.54(1 \mathrm{H}, \mathrm{d}$, $J=0.6 \mathrm{~Hz}), 7.61(2 \mathrm{H}, \mathrm{t}, J=7.5 \mathrm{~Hz}), 7.72-7.78(1 \mathrm{H}, \mathrm{m}), 8.07-8.10(2 \mathrm{H}, \mathrm{m})$.

\section{Ethyl 6-ethyl-3-hydroxy-1-methyl-4-oxo-5-(2-oxo-2-phenylethyl)-4,5-dihydro-1H- pyrrolo[3,2-c]pyridine-2-carboxylate (18a)}

A mixture of 17a (7.00 g, $19.3 \mathrm{mmol})$, sarcosine ethyl ester hydrochloride (5.94 g, $38.7 \mathrm{mmol}), \mathrm{Et}_{3} \mathrm{~N}(29.7 \mathrm{~mL}, 193 \mathrm{mmol})$, and $\mathrm{EtOH}(100 \mathrm{~mL})$ was stirred at reflux for 2 days. After cooling, the mixture was diluted with water and acidified with $5 \mathrm{M} \mathrm{HCl}$ aq. The resulting solid was collected and washed with water and hexane / AcOEt to give the title compound $(5.70 \mathrm{~g}, 74 \%)$ as a white solid. ${ }^{1} \mathrm{H}$ NMR (DMSO- $\left.d_{6}\right) \delta 1.18(3 \mathrm{H}, \mathrm{t}, J=$ $7.4 \mathrm{~Hz}), 1.31(3 \mathrm{H}, \mathrm{t}, J=7.1 \mathrm{~Hz}), 2.56(2 \mathrm{H}, \mathrm{q}, J=7.4 \mathrm{~Hz}), 3.80(3 \mathrm{H}, \mathrm{s}), 4.30(2 \mathrm{H}, \mathrm{q}, J=$ $7.1 \mathrm{~Hz}), 5.55(2 \mathrm{H}, \mathrm{s}), 6.43(1 \mathrm{H}, \mathrm{s}), 7.60(2 \mathrm{H}, \mathrm{t}, J=7.6 \mathrm{~Hz}), 7.68-7.79(1 \mathrm{H}, \mathrm{m})$, 8.00-8.21 (2H, m), $8.90(1 \mathrm{H}, \mathrm{s})$.

Ethyl 3-hydroxy-1-methyl-4-oxo-5-(2-oxo-2-phenylethyl)-4,5,6,7,8,9-hexahydro$1 H$-pyrrolo[3,2-c]quinoline-2-carboxylate (18b)

A mixture of the compound $17 \mathbf{b}(270 \mathrm{mg}, 0.724 \mathrm{mmol})$, sarcosine ethyl ester hydrochloride (222 mg, $1.45 \mathrm{mmol}), \mathrm{Et}_{3} \mathrm{~N}$ (1.00 mL, $\left.7.24 \mathrm{mmol}\right)$, and $\mathrm{EtOH}(5 \mathrm{~mL})$ was stirred at reflux for 2 days. After cooling, water $(10 \mathrm{~mL})$ was added to the mixture and 
the resulting solid was collected. This was used for the next reaction without further purification.

\section{Ethyl 3-hydroxy-1,6-dimethyl-4-oxo-5-(2-oxo-2-phenylethyl)-4,5-dihydro-1H- pyrrolo[3,2-c]pyridine-2-carboxylate (18c)}

In the same manner as in the preparation of 18a, the title compound $(1.50 \mathrm{~g}, 68 \%)$ was obtained as a white powder from 17c (2.00 g, $5.99 \mathrm{mmol}) .{ }^{1} \mathrm{H}$ NMR (DMSO- $\left.d_{6}\right) \delta$ $1.31(3 \mathrm{H}, \mathrm{t}, J=7.1 \mathrm{~Hz}), 2.26(3 \mathrm{H}, \mathrm{s}), 3.77(3 \mathrm{H}, \mathrm{s}), 4.30(2 \mathrm{H}, \mathrm{q}, J=7.1 \mathrm{~Hz}), 5.57(2 \mathrm{H}, \mathrm{s})$, 6.52 (1H, s), 7.54-7.67 (2H, m), 7.69-7.79 (1H, m), 8.03-8.18 (2H, m), $8.90(1 \mathrm{H}, \mathrm{s})$.

\section{Ethyl 3-ethoxy-6-ethyl-1-methyl-4-oxo-5-(2-oxo-2-phenylethyl)-4,5-dihydro-1H- pyrrolo[3,2-c]pyridine-2-carboxylate (19a) \\ $\mathrm{K}_{2} \mathrm{CO}_{3}(10.6 \mathrm{~g}, 76.8 \mathrm{mmol})$ and $\mathrm{Et}_{2} \mathrm{SO}_{4}(4.03 \mathrm{~mL}, 30.1 \mathrm{mmol})$ were added to a} solution of 18a $(9.80 \mathrm{~g}, 25.6 \mathrm{mmol})$ in acetone $(196 \mathrm{~mL})$ and the mixture was refluxed for $1 \mathrm{~h}$. $\mathrm{Et}_{2} \mathrm{SO}_{4}(4.03 \mathrm{~mL}, 30.1 \mathrm{mmol})$ and acetone $(70 \mathrm{~mL})$ were added, and the mixture was refluxed for $17 \mathrm{~h}$. The mixture was diluted with water $(400 \mathrm{~mL})$ and the resulting precipitate was collected by filtration and washed with water and hexane / AcOEt to give the title compound $(8.58 \mathrm{~g}, 82 \%)$ as a white solid. ${ }^{1} \mathrm{H}$ NMR (DMSO- $\left.d_{6}\right) \delta$ 1.13-1.27 (6H, m), $1.31(3 \mathrm{H}, \mathrm{t}, J=7.1 \mathrm{~Hz}), 2.57(2 \mathrm{H}, \mathrm{q}, J=7.3 \mathrm{~Hz}), 3.84(3 \mathrm{H}, \mathrm{s}), 4.15$ $(2 \mathrm{H}, \mathrm{q}, J=7.1 \mathrm{~Hz}), 4.26(2 \mathrm{H}, \mathrm{q}, J=7.1 \mathrm{~Hz}), 5.57(2 \mathrm{H}, \mathrm{s}), 6.49(1 \mathrm{H}, \mathrm{s}), 7.56-7.66(2 \mathrm{H}$, m), 7.69-7.77 (1H, m), 8.07-8.16 (2H, m).

\section{Ethyl 6-ethyl-3-(2-fluoroethoxy)-1-methyl-4-oxo-5-(2-oxo-2-phenylethyl)-4,5- dihydro-1H-pyrrolo[3,2-c]pyridine-2-carboxylate (19b)}

2-Fluoroethyl iodide (512 mg, $2.94 \mathrm{mmol}$ ) was added to a mixture of 18a (750 $\mathrm{mg}, 1.96 \mathrm{mmol})$ and $\mathrm{DBU}(0.440 \mathrm{~mL}, 2.94 \mathrm{mmol})$ in DMF $(10 \mathrm{~mL})$ and the mixture was stirred at room temperature for $15 \mathrm{~h}$. The mixture was diluted with water and extracted with AcOEt. The organic layer was washed with water and brine, dried over $\mathrm{MgSO}_{4}$, and concentrated in vacuo. The residue was purified by basic silica gel column chromatography (AcOEt) to give the title compound $(649 \mathrm{mg}, 77 \%)$ as a white solid. ${ }^{1} \mathrm{H}$ NMR $\left(\mathrm{DMSO}-d_{6}\right) \delta 1.19(3 \mathrm{H}, \mathrm{t}, J=7.3 \mathrm{~Hz}), 1.30(3 \mathrm{H}, \mathrm{t}, J=7.1 \mathrm{~Hz}), 2.58(2 \mathrm{H}, \mathrm{q}, J=$ $7.3 \mathrm{~Hz}), 3.85(3 \mathrm{H}, \mathrm{s}), 4.26(2 \mathrm{H}, \mathrm{q}, J=7.1 \mathrm{~Hz}), 4.32-4.36(1 \mathrm{H}, \mathrm{m}), 4.42-4.47(1 \mathrm{H}, \mathrm{m})$, 4.53-4.59 (1H, m), 4.69-4.75 (1H, m), $5.58(2 \mathrm{H}, \mathrm{s}), 6.51(1 \mathrm{H}, \mathrm{s}), 7.61(2 \mathrm{H}, \mathrm{t}, J=7.6 \mathrm{~Hz})$, 7.70-7.77 (1H, m), 8.08-8.14 (2H, m). 
Ethyl 3-(2,2-difluoroethoxy)-6-ethyl-1-methyl-4-oxo-5-(2-oxo-2-phenylethyl)-4,5dihydro-1H-pyrrolo[3,2-c]pyridine-2-carboxylate (19c)

2,2-Difluoroethyl trifluoromethanesulfonate $(336 \mathrm{mg}, 1.57 \mathrm{mmol}$ ) was added to a mixture of 18a (500 mg, $1.31 \mathrm{mmol})$ and $\mathrm{Cs}_{2} \mathrm{CO}_{3}(554 \mathrm{mg}, 1.70 \mathrm{mmol})$ in DMF (5 mL) and the mixture was stirred at room temperature for $2 \mathrm{~h}$. The mixture was diluted with water $(15 \mathrm{~mL})$ and the precipitate was collected by filtration. The collected material was washed with water, $\mathrm{EtOH}$ and $\mathrm{Et}_{2} \mathrm{O}$, and dried in vacuo to give the title compound ( 0.45 g, 77\%) as a white solid. ${ }^{1} \mathrm{H}$ NMR (DMSO- $\left.d_{6}\right) \delta 1.19(3 \mathrm{H}, \mathrm{t}, J=7.4 \mathrm{~Hz}), 1.30(3 \mathrm{H}, \mathrm{t}, J$ $=7.2 \mathrm{~Hz}), 2.59(2 \mathrm{H}, \mathrm{q}, J=7.4 \mathrm{~Hz}), 3.86(3 \mathrm{H}, \mathrm{s}), 4.26(2 \mathrm{H}, \mathrm{q}, J=7.2 \mathrm{~Hz}), 4.42(2 \mathrm{H}, \mathrm{td}$, $J=14.9,3.9 \mathrm{~Hz}), 5.61(2 \mathrm{H}, \mathrm{s}), 6.27(1 \mathrm{H}, \mathrm{tt}, J=54.9,3.9 \mathrm{~Hz}), 6.54(1 \mathrm{H}, \mathrm{s}), 7.61(2 \mathrm{H}, \mathrm{t}$, $J=7.5 \mathrm{~Hz}), 7.74(1 \mathrm{H}, \mathrm{t}, J=7.5 \mathrm{~Hz}), 8.10-8.13(2 \mathrm{H}, \mathrm{m})$.

Ethyl 6-ethyl-1-methyl-4-oxo-5-(2-oxo-2-phenylethyl)-3-(2,2,2-trifluoroethoxy)4,5-dihydro-1H-pyrrolo[3,2-c]pyridine-2-carboxylate (19d)

In the same manner as in the preparation of 19c, the title compound $(7.81 \mathrm{~g}, 86 \%)$ was obtained as a white solid from 18a (7.47 g, $19.5 \mathrm{mmol}) .{ }^{1} \mathrm{H}$ NMR (DMSO- $\left.d_{6}\right) \delta$ $1.19(3 \mathrm{H}, \mathrm{t}, J=7.4 \mathrm{~Hz}), 1.29(3 \mathrm{H}, \mathrm{t}, J=7.1 \mathrm{~Hz}), 2.59(2 \mathrm{H}, \mathrm{q}, J=7.4 \mathrm{~Hz}), 3.86(3 \mathrm{H}, \mathrm{s})$, $4.26(2 \mathrm{H}, \mathrm{q}, J=7.1 \mathrm{~Hz}), 4.83(2 \mathrm{H}, \mathrm{q}, J=9.3 \mathrm{~Hz}), 5.61(2 \mathrm{H}, \mathrm{s}), 6.56(1 \mathrm{H}, \mathrm{s}), 7.61(2 \mathrm{H}, \mathrm{t}$, $J=7.6 \mathrm{~Hz}), 7.69-7.79(1 \mathrm{H}, \mathrm{m}), 8.06-8.18(2 \mathrm{H}, \mathrm{m})$.

Ethyl 6-ethyl-3-methoxy-1-methyl-4-oxo-5-(2-oxo-2-phenylethyl)-4,5-dihydro-1Hpyrrolo[3,2-c]pyridine-2-carboxylate (19e)

In the same manner as in the preparation of $\mathbf{1 9 b}$, the title compound (156 mg, $23 \%$ ) was obtained as a white powder from 18a (650 mg, $1.70 \mathrm{mmol}) .{ }^{1} \mathrm{H} \mathrm{NMR}$ $\left(\mathrm{DMSO}-d_{6}\right) \delta 1.19(3 \mathrm{H}, \mathrm{t}, J=7.3 \mathrm{~Hz}), 1.30(3 \mathrm{H}, \mathrm{t}, J=7.1 \mathrm{~Hz}), 2.58(2 \mathrm{H}, \mathrm{q}, J=7.4 \mathrm{~Hz})$, $3.84(3 \mathrm{H}, \mathrm{s}), 3.85(3 \mathrm{H}, \mathrm{s}), 4.27(2 \mathrm{H}, \mathrm{q}, J=7.0 \mathrm{~Hz}), 5.58(2 \mathrm{H}, \mathrm{s}), 6.50(1 \mathrm{H}, \mathrm{s}), 7.61(2 \mathrm{H}$, $\mathrm{t}, J=7.6 \mathrm{~Hz}), 7.67-7.82(1 \mathrm{H}, \mathrm{m}), 8.03-8.19(2 \mathrm{H}, \mathrm{m})$.

Ethyl 6-ethyl-1-methyl-4-oxo-5-(2-oxo-2-phenylethyl)-3-\{[(trifluoromethyl) sulfonyl]oxy\}-4,5-dihydro-1H-pyrrolo[3,2-c]pyridine-2-carboxylate (19f)

A mixture of 18a (300 mg, $0.784 \mathrm{mmol}), \mathrm{Tf}_{2} \mathrm{O}(158 \mu \mathrm{L}, 0.941 \mathrm{mmol})$, and pyridine $(6 \mathrm{~mL})$ was stirred at $60{ }^{\circ} \mathrm{C}$ for $3 \mathrm{~h}$ under $\mathrm{N}_{2}$ atmosphere. The mixture was diluted with water $(50 \mathrm{~mL})$ and extracted with AcOEt $(100 \mathrm{~mL})$. The extract was washed with brine $(50 \mathrm{~mL})$, dried over $\mathrm{MgSO}_{4}$, and concentrated in vacuo. The residue was purified by silica gel column chromatography (hexane/AcOEt=1/1 to AcOEt) to give the title compound ( $239 \mathrm{mg}, 59 \%$ ) as a pale yellow powder. ${ }^{1} \mathrm{H}$ NMR (DMSO- $\left.d_{6}\right) \delta$ 
$1.20(3 \mathrm{H}, \mathrm{t}, J=7.3 \mathrm{~Hz}), 1.33(3 \mathrm{H}, \mathrm{t}, J=7.2 \mathrm{~Hz}), 2.60(2 \mathrm{H}, \mathrm{q}, J=7.3 \mathrm{~Hz}), 3.95(3 \mathrm{H}, \mathrm{s})$, $4.34(2 \mathrm{H}, \mathrm{q}, J=7.2 \mathrm{~Hz}), 5.64(2 \mathrm{H}, \mathrm{s}), 6.64(1 \mathrm{H}, \mathrm{s}), 7.57-7.68(2 \mathrm{H}, \mathrm{m}), 7.70-7.81(1 \mathrm{H}$, $\mathrm{m}), 8.07-8.19(2 \mathrm{H}, \mathrm{m})$.

Ethyl 3-ethenyl-6-ethyl-1-methyl-4-oxo-5-(2-oxo-2-phenylethyl)-4,5-dihydro-1Hpyrrolo[3,2-c]pyridine-2-carboxylate (19g)

A mixture of $19 \mathrm{f}(218 \mathrm{mg}, 0.424 \mathrm{mmol})$, vinyltributyltin $(328 \mu \mathrm{L}, 1.28 \mathrm{mmol})$, $\mathrm{Pd}\left(\mathrm{PPh}_{3}\right)_{4}(148 \mathrm{mg}, 0.128 \mathrm{mmol})$ and DMF $(5.9 \mathrm{~mL})$ was stirred at $100{ }^{\circ} \mathrm{C}$ for $3 \mathrm{~h}$ under Ar atmosphere. The mixture was diluted with water $(50 \mathrm{~mL})$ and extracted with AcOEt $(100 \mathrm{~mL})$. The extract was washed with brine $(50 \mathrm{~mL})$, dried over $\mathrm{MgSO}_{4}$, and concentrated in vacuo. The insoluble material was removed by filtration and the filtrate was concentrated in vacuo. The precipitate was collected by filtration and washed with IPE to give the title compound $(120 \mathrm{mg}, 72 \%)$ as a grey solid. ${ }^{1} \mathrm{H}$ NMR (DMSO- $\left.d_{6}\right) \delta$ $1.20(3 \mathrm{H}, \mathrm{t}, J=7.3 \mathrm{~Hz}), 1.33(3 \mathrm{H}, \mathrm{t}, J=7.1 \mathrm{~Hz}), 2.61(2 \mathrm{H}, \mathrm{q}, J=7.3 \mathrm{~Hz}), 3.85(3 \mathrm{H}, \mathrm{s})$, $4.33(2 \mathrm{H}, \mathrm{q}, J=7.1 \mathrm{~Hz}), 5.29-5.43(1 \mathrm{H}, \mathrm{m}), 5.59(2 \mathrm{H}, \mathrm{s}), 6.41-6.59(2 \mathrm{H}, \mathrm{m}), 7.23(1 \mathrm{H}$, $\mathrm{dd}, J=17.7,11.8 \mathrm{~Hz}), 7.55-7.67(2 \mathrm{H}, \mathrm{m}), 7.68-7.81(1 \mathrm{H}, \mathrm{m}), 8.01-8.20(2 \mathrm{H}, \mathrm{m})$.

\section{Ethyl 3,6-diethyl-1-methyl-4-oxo-5-(2-oxo-2-phenylethyl)-4,5-dihydro-1H-pyrrolo} [3,2-c]pyridine-2-carboxylate (19h)

A mixture of 19g (1.33 g, $3.40 \mathrm{mmol}), 10 \% \mathrm{Pd}-\mathrm{C}(270 \mathrm{mg})$ and THF $(50 \mathrm{~mL}) /$ $\mathrm{MeOH}(25 \mathrm{~mL})$ was stirred at room temperature for $7 \mathrm{~h}$ under $\mathrm{H}_{2}$ atmosphere. The catalyst was removed by filtration and the filtrate was concentrated in vacuo. The precipitate was collected by filtration to give the title compound $(1.35 \mathrm{~g}, 100 \%)$ as a white solid. ${ }^{1} \mathrm{H}$ NMR (DMSO- $\left.d_{6}\right) \delta 1.09(3 \mathrm{H}, \mathrm{t}, J=7.2 \mathrm{~Hz}), 1.19(3 \mathrm{H}, \mathrm{t}, J=7.5 \mathrm{~Hz}$ ), $1.33(3 \mathrm{H}, \mathrm{t}, J=7.2 \mathrm{~Hz}), 2.58(2 \mathrm{H}, \mathrm{q}, J=7.2 \mathrm{~Hz}), 3.07-3.19(2 \mathrm{H}, \mathrm{m}), 3.87(3 \mathrm{H}, \mathrm{s}), 4.30$ $(2 \mathrm{H}, \mathrm{q}, J=7.2 \mathrm{~Hz}), 5.59(2 \mathrm{H}, \mathrm{s}), 6.48(1 \mathrm{H}, \mathrm{s}), 7.58-7.64(2 \mathrm{H}, \mathrm{m}), 7.70-7.77(1 \mathrm{H}, \mathrm{m})$, 8.08-8.14 (2H, m).

Ethyl 3-methoxy-1-methyl-4-oxo-5-(2-oxo-2-phenylethyl)-4,5,6,7,8,9-hexahydro$1 H$-pyrrolo[3,2-c]quinoline-2-carboxylate (19i)

In the same manner as in the preparation of 19a, the title compound $(34.0 \mathrm{mg}$, $11 \%$ in 2 steps) was obtained as a white powder from 18b. ${ }^{1} \mathrm{H}$ NMR (DMSO- $\left.d_{6}\right) \delta 1.31$ $(3 \mathrm{H}, \mathrm{t}, J=7.1 \mathrm{~Hz}), 1.60-1.77(4 \mathrm{H}, \mathrm{m}), 2.45-2.55(2 \mathrm{H}, \mathrm{m}), 2.94-3.02(2 \mathrm{H}, \mathrm{m}), 3.81(3 \mathrm{H}$, s), $4.03(3 \mathrm{H}, \mathrm{s}), 4.27(2 \mathrm{H}, \mathrm{q}, J=7.1 \mathrm{~Hz}), 5.62(2 \mathrm{H}, \mathrm{s}), 7.61(2 \mathrm{H}, \mathrm{t}, J=7.5 \mathrm{~Hz}), 7.73(1 \mathrm{H}$, $\mathrm{t}, J=7.5 \mathrm{~Hz}), 8.10(2 \mathrm{H}, \mathrm{d}, J=7.5 \mathrm{~Hz})$. 
Ethyl 3-methoxy-1,6-dimethyl-4-oxo-5-(2-oxo-2-phenylethyl)-4,5-dihydro-1Hpyrrolo[3,2-c]pyridine-2-carboxylate (19j)

In the same manner as in the preparation of $19 \mathbf{b}$, the title compound $(390 \mathrm{mg}$, $26 \%$ ) was obtained as a white powder from 18c (1.45 g, $3.94 \mathrm{mmol}) .{ }^{1} \mathrm{H}$ NMR $\left(\mathrm{DMSO}-d_{6}\right) \delta 1.30(3 \mathrm{H}, \mathrm{t}, J=7.1 \mathrm{~Hz}), 2.28(3 \mathrm{H}, \mathrm{s}), 3.81(3 \mathrm{H}, \mathrm{s}), 3.86(3 \mathrm{H}, \mathrm{s}), 4.27(2 \mathrm{H}$, q, $J=7.1 \mathrm{~Hz}), 5.60(2 \mathrm{H}, \mathrm{s}), 6.59(1 \mathrm{H}, \mathrm{s}), 7.54-7.66(2 \mathrm{H}, \mathrm{m}), 7.69-7.79(1 \mathrm{H}, \mathrm{m})$, 8.05-8.16 (2H, m).

\section{3-Ethoxy-6-ethyl-1-methyl-4-oxo-5-(2-oxo-2-phenylethyl)-4,5-dihydro-1H-pyrrolo} [3,2-c]pyridine-2-carboxylic acid (20a)

$8 \mathrm{M} \mathrm{NaOH}$ aq. (42.9 mL) was added to a solution of 19a $(8.58 \mathrm{~g}, 20.9 \mathrm{mmol})$ in $\mathrm{EtOH}(257 \mathrm{~mL})$ and the mixture was stirred at $60{ }^{\circ} \mathrm{C}$ for $30 \mathrm{~min}$. The mixture was diluted with water and acidified with $5 \mathrm{M} \mathrm{HCl}$ aq. The resulting precipitate was collected by filtration, and washed with water and $\mathrm{Et}_{2} \mathrm{O}$ to give the title compound ( $7.12 \mathrm{~g}, 89 \%$ ) as a beige powder. ${ }^{1} \mathrm{H}$ NMR (DMSO- $\left.d_{6}\right) \delta 1.12-1.27(6 \mathrm{H}, \mathrm{m}), 2.57(2 \mathrm{H}, \mathrm{q}, J=7.4 \mathrm{~Hz})$, $3.84(3 \mathrm{H}, \mathrm{s}), 4.16(2 \mathrm{H}, \mathrm{q}, J=7.1 \mathrm{~Hz}), 5.58(2 \mathrm{H}, \mathrm{s}), 6.48(1 \mathrm{H}, \mathrm{s}), 7.55-7.66(2 \mathrm{H}, \mathrm{m})$, 7.68-7.78 (1H, m), 8.05-8.19 (2H, m), $12.41(1 \mathrm{H}$, br s).

The following compounds $\mathbf{2 0 b}-\mathbf{j}$ were prepared in a same manner similar to that described for 20a.

\section{6-Ethyl-3-(2-fluoroethoxy)-1-methyl-4-oxo-5-(2-oxo-2-phenylethyl)-4,5-dihydro}

-1H-pyrrolo[3,2-c]pyridine-2-carboxylic acid (20b)

Yield 56\%, white powder. ${ }^{1} \mathrm{H}$ NMR (DMSO- $\left.d_{6}\right) \delta 1.19(3 \mathrm{H}, \mathrm{t}, J=7.4 \mathrm{~Hz}), 2.58$ $(2 \mathrm{H}, \mathrm{q}, J=7.4 \mathrm{~Hz}), 3.85(3 \mathrm{H}, \mathrm{s}), 4.32-4.36(1 \mathrm{H}, \mathrm{m}), 4.42-4.47(1 \mathrm{H}, \mathrm{m}), 4.54-4.59(1 \mathrm{H}$, m), 4.70-4.74 (1H, m), $5.58(2 \mathrm{H}, \mathrm{s}), 6.50(1 \mathrm{H}, \mathrm{s}), 7.61(2 \mathrm{H}, \mathrm{t}, J=7.6 \mathrm{~Hz}), 7.70-7.77(1 \mathrm{H}$, m), 8.09-8.15 (2H, m), 12.48 (1H, br s).

\section{3-(2,2-Difluoroethoxy)-6-ethyl-1-methyl-4-oxo-5-(2-oxo-2-phenylethyl)-4,5-dihydro} -1H-pyrrolo[3,2-c]pyridine-2-carboxylic acid (20c)

Yield 83\%, white powder. ${ }^{1} \mathrm{H}$ NMR (DMSO- $\left.d_{6}\right) \delta 1.19(3 \mathrm{H}, \mathrm{t}, J=7.2 \mathrm{~Hz}), 2.58$ $(2 \mathrm{H}, \mathrm{q}, J=7.3 \mathrm{~Hz}), 3.85(3 \mathrm{H}, \mathrm{s}), 4.40(2 \mathrm{H}, \mathrm{td}, J=14.6,1.2 \mathrm{~Hz}), 5.60(2 \mathrm{H}, \mathrm{s}), 6.26(1 \mathrm{H}$, $\mathrm{tt}, J=55.0,3.9 \mathrm{~Hz}), 6.77(1 \mathrm{H}, \mathrm{s}), 7.58-7.76(3 \mathrm{H}, \mathrm{m}), 8.12(2 \mathrm{H}, \mathrm{d}, J=7.5 \mathrm{~Hz})$, 12.50-12.70 (1H, m). 
6-Ethyl-1-methyl-4-oxo-5-(2-oxo-2-phenylethyl)-3-(2,2,2-trifluoroethoxy)-4,5dihydro-1H-pyrrolo[3,2-c]pyridine-2-carboxylic acid (20d)

Yield 93\%, white powder. ${ }^{1} \mathrm{H}$ NMR (DMSO- $\left.d_{6}\right) \delta 1.19(3 \mathrm{H}, \mathrm{t}, J=7.4 \mathrm{~Hz}), 2.58$ $(2 \mathrm{H}, \mathrm{q}, J=7.4 \mathrm{~Hz}), 3.86(3 \mathrm{H}, \mathrm{s}), 4.82(2 \mathrm{H}, \mathrm{q}, J=9.2 \mathrm{~Hz}), 5.61(2 \mathrm{H}, \mathrm{s}), 6.54(1 \mathrm{H}, \mathrm{s})$, $7.61(2 \mathrm{H}, \mathrm{t}, J=7.6 \mathrm{~Hz}), 7.70-7.77(1 \mathrm{H}, \mathrm{m}), 8.07-8.16(2 \mathrm{H}, \mathrm{m}), 12.74(1 \mathrm{H}, \mathrm{br} \mathrm{s})$.

6-Ethyl-3-methoxy-1-methyl-4-oxo-5-(2-oxo-2-phenylethyl)-4,5-dihydro-1Hpyrrolo[3,2-c]pyridine-2-carboxylic acid (20e)

Yield 79\%, white powder. ${ }^{1} \mathrm{H}$ NMR (DMSO- $\left.d_{6}\right) \delta 1.19(3 \mathrm{H}, \mathrm{t}, J=7.3 \mathrm{~Hz}), 2.57$ $(2 \mathrm{H}, \mathrm{q}, J=7.3 \mathrm{~Hz}), 3.84(3 \mathrm{H}, \mathrm{s}), 3.85(3 \mathrm{H}, \mathrm{s}), 5.58(2 \mathrm{H}, \mathrm{s}), 6.48(1 \mathrm{H}, \mathrm{s}), 7.61(2 \mathrm{H}, \mathrm{t}, J=$ 7.6 Hz), 7.67-7.86 (1H, m), 7.97-8.31 (2H, m), $12.51(1 \mathrm{H}$, br s).

3,6-Diethyl-1-methyl-4-oxo-5-(2-oxo-2-phenylethyl)-4,5-dihydro-1H-pyrrolo[3,2-c] pyridine-2-carboxylic acid (20h)

Yield 99\%, white powder. ${ }^{1} \mathrm{H}$ NMR (DMSO- $\left.d_{6}\right) \delta 1.07(3 \mathrm{H}, \mathrm{t}, J=7.3 \mathrm{~Hz}), 1.19$ $(3 \mathrm{H}, \mathrm{t}, J=7.4 \mathrm{~Hz}), 2.57(2 \mathrm{H}, \mathrm{q}, J=7.4 \mathrm{~Hz}), 3.11(2 \mathrm{H}, \mathrm{q}, J=7.3 \mathrm{~Hz}), 3.87(3 \mathrm{H}, \mathrm{s}), 5.58$ $(2 \mathrm{H}, \mathrm{s}), 6.46(1 \mathrm{H}, \mathrm{s}), 7.56-7.66(2 \mathrm{H}, \mathrm{m}), 7.68-7.78(1 \mathrm{H}, \mathrm{m}), 8.05-8.17(2 \mathrm{H}, \mathrm{m}), 12.80$ $(1 \mathrm{H}$, br s).

3-Methoxy-1-methyl-4-oxo-5-(2-oxo-2-phenylethyl)-4,5,6,7,8,9-hexahydro-1Hpyrrolo[3,2-c]quinoline-2-carboxylic acid (20i)

Yield 23\%, white powder. ${ }^{1} \mathrm{H}$ NMR (DMSO- $\left.d_{6}\right) \delta 1.67(4 \mathrm{H}, \mathrm{m}), 2.44-2.52(2 \mathrm{H}$, $\mathrm{m})$, 2.94-3.02 $(2 \mathrm{H}, \mathrm{m}), 3.81(3 \mathrm{H}, \mathrm{s}), 4.05(3 \mathrm{H}, \mathrm{s}), 5.62(2 \mathrm{H}, \mathrm{s}), 7.56-7.65(2 \mathrm{H}, \mathrm{m})$, 7.70-7.78 (1H, m), $8.10(2 \mathrm{H}, \mathrm{d}, J=7.6 \mathrm{~Hz}), 12.56(1 \mathrm{H}, \mathrm{br} \mathrm{s})$.

\section{3-Methoxy-1,6-dimethyl-4-oxo-5-(2-oxo-2-phenylethyl)-4,5-dihydro-1H-pyrrolo}

\section{[3,2-c]pyridine-2-carboxylic acid (20j)}

Yield 89\%, white powder. ${ }^{1} \mathrm{H}$ NMR (DMSO- $\left.d_{6}\right) \delta 2.28(3 \mathrm{H}, \mathrm{s}), 3.81(3 \mathrm{H}, \mathrm{s}), 3.86$ $(3 \mathrm{H}, \mathrm{s}), 5.60(2 \mathrm{H}, \mathrm{s}), 6.58(1 \mathrm{H}, \mathrm{s}), 7.61(2 \mathrm{H}, \mathrm{t}, J=7.4 \mathrm{~Hz}), 7.74(1 \mathrm{H}, \mathrm{t}, J=7.3 \mathrm{~Hz}), 8.11$ $(2 \mathrm{H}, \mathrm{d}, J=7.7 \mathrm{~Hz}), 12.50(1 \mathrm{H}, \mathrm{br} \mathrm{s})$.

\section{3-Methoxy-1,6-dimethyl-4-oxo-5-(2-oxo-2-phenylethyl)- $N$-piperidin-4-yl-4,5-} dihydro-1H-pyrrolo[3,2-c]pyridine-2-carboxamide hydrochloride (21a)

A mixture of $\mathbf{2 0 j}$ (290 mg, $0.818 \mathrm{mmol}$ ), EDC (236 mg, $1.23 \mathrm{mmol})$, HOBt (166 $\mathrm{mg}, 1.23 \mathrm{mmol}$ ), and DMF ( $5 \mathrm{~mL}$ ) was stirred at room temperature for $15 \mathrm{~h}$, after which 4-amino-1-Boc-piperidine $(212 \mathrm{mg}, 1.06 \mathrm{mmol})$ was added and the mixture was stirred 
at room temperature for $15 \mathrm{~h}$. The mixture was diluted with water and extracted with AcOEt. The organic layer was washed with water and brine, dried over $\mathrm{MgSO}_{4}$, and concentrated in vacuo. The residue was purified by basic silica gel column chromatography (AcOEt) to give tert-butyl 4-(\{[3-methoxy-1,6-dimethyl-4-oxo-5-(2-oxo-2-phenylethyl)-4,5-dihydro-1H-pyrrolo[3 ,2-c]pyridin-2-yl]carbonyl \}amino)piperidine-1-carboxylate. $4 \mathrm{M} \mathrm{HCl}$ in AcOEt (4 mL) was added to a solution of the compound obtained above in AcOEt ( $4 \mathrm{~mL})$ and the mixture was stirred at room temperature for $2 \mathrm{~h}$. The precipitated solid was collected by filtration, and washed with AcOEt to give the title compound $(240 \mathrm{mg}, 62 \%)$ as a white powder. ${ }^{1} \mathrm{H}$ NMR (DMSO- $\left.d_{6}\right) \delta$ 1.61-1.84 $(2 \mathrm{H}, \mathrm{m}), 1.95-2.11(2 \mathrm{H}, \mathrm{m}), 2.28(3 \mathrm{H}, \mathrm{s})$, 2.92-3.12 (2H, m), 3.20-3.32 (2H, m), $3.83(3 \mathrm{H}, \mathrm{s}), 3.94-4.15(4 \mathrm{H}, \mathrm{m}), 5.62(2 \mathrm{H}, \mathrm{s})$, $6.59(1 \mathrm{H}, \mathrm{s}), 7.61(2 \mathrm{H}, \mathrm{t}, J=7.6 \mathrm{~Hz}), 7.68-7.81(2 \mathrm{H}, \mathrm{m}), 8.04-8.19(2 \mathrm{H}, \mathrm{m}), 8.64(1 \mathrm{H}$, br s.), 8.87 (1H, br s).

\section{6-Ethyl-3-methoxy-1-methyl-4-oxo-5-(2-oxo-2-phenylethyl)- $N$-piperidin-4-yl-4,5- dihydro-1H-pyrrolo[3,2-c]pyridine-2-carboxamide hydrochloride (21b)}

In the same manner as in the preparation of 21a, the title compound $(97.2 \mathrm{mg}$, $74 \%$ ) was obtained as a white powder from 20e (100 mg, $0.271 \mathrm{mmol}) .{ }^{1} \mathrm{H}$ NMR $\left(\mathrm{DMSO}-d_{6}\right) \delta 1.19(3 \mathrm{H}, \mathrm{t}, J=7.3 \mathrm{~Hz}), 1.66-1.85(2 \mathrm{H}, \mathrm{m}), 1.97-2.09(2 \mathrm{H}, \mathrm{m}), 2.58(2 \mathrm{H}$, q, $J=7.4 \mathrm{~Hz}), 2.95-3.10(2 \mathrm{H}, \mathrm{m}), 3.19-3.30(2 \mathrm{H}, \mathrm{m}), 3.87(3 \mathrm{H}, \mathrm{s}), 3.96-4.14(4 \mathrm{H}, \mathrm{m})$, $5.60(2 \mathrm{H}, \mathrm{s}), 6.49(1 \mathrm{H}, \mathrm{s}), 7.55-7.66(2 \mathrm{H}, \mathrm{m}), 7.69-7.79(2 \mathrm{H}, \mathrm{m}), 8.12(2 \mathrm{H}, \mathrm{d}, J=7.7$ $\mathrm{Hz}), 8.92(2 \mathrm{H}$, br s).

\section{3-Ethoxy-6-ethyl- $N$-[1-(hydroxyacetyl)piperidin-4-yl]-1-methyl-4-oxo-5-(2-oxo-2- phenylethyl)-4,5-dihydro-1H-pyrrolo[3,2-c]pyridine-2-carboxamide (22a)}

EDC (55.6 mg, $0.290 \mathrm{mmol})$ at $0{ }^{\circ} \mathrm{C}$ was added to a mixture of the compound 21a (74.0 mg, $0.194 \mathrm{mmol}), 24$ (49.1 mg, $0.252 \mathrm{mmol}$ ), HOBt (39.2 mg, $0.290 \mathrm{mmol}$ ), and $\mathrm{Et}_{3} \mathrm{~N}(34.9 \mathrm{~mL}, 0.252 \mathrm{mmol})$ in DMF $(3 \mathrm{~mL})$ and the mixture was stirred at room temperature for $15 \mathrm{~h}$. The reaction mixture was diluted with water and extracted twice with AcOEt. The combined extract was washed with water and saturated brine, dried over $\mathrm{MgSO}_{4}$, and concentrated in vacuo. The residue was purified by basic silica gel column chromatography (AcOEt) and the obtained solid was recrystallized from AcOEt to give the title compound $(61.2 \mathrm{mg}, 60 \%)$ as white crystals; mp $204{ }^{\circ} \mathrm{C}$. ${ }^{1} \mathrm{H}$ NMR $\left(\mathrm{DMSO}-d_{6}\right) \delta 1.13-1.29(6 \mathrm{H}, \mathrm{m}), 1.32-1.56(2 \mathrm{H}, \mathrm{m}), 1.83-1.96(2 \mathrm{H}, \mathrm{m}), 2.57(2 \mathrm{H}, \mathrm{q}, J=$ $7.4 \mathrm{~Hz}), 2.80-2.94(1 \mathrm{H}, \mathrm{m}), 3.04-3.19(1 \mathrm{H}, \mathrm{m}), 3.59-3.72(1 \mathrm{H}, \mathrm{m}), 3.90(3 \mathrm{H}, \mathrm{s})$, $3.95-4.14(3 \mathrm{H}, \mathrm{m}), 4.17-4.27(1 \mathrm{H}, \mathrm{m}), 4.34(2 \mathrm{H}, \mathrm{q}, J=7.2 \mathrm{~Hz}), 4.51(1 \mathrm{H}, \mathrm{t}, J=5.4 \mathrm{~Hz})$, 
$5.59(2 \mathrm{H}, \mathrm{s}), 6.49(1 \mathrm{H}, \mathrm{s}), 7.56-7.65(2 \mathrm{H}, \mathrm{m}), 7.66-7.77(2 \mathrm{H}, \mathrm{m}), 8.07-8.14(2 \mathrm{H}, \mathrm{m})$. Anal. calcd for $\mathrm{C}_{28} \mathrm{H}_{34} \mathrm{~N}_{4} \mathrm{O}_{6}$ : C 64.35; $\mathrm{H}$ 6.56; N 10.72. Found: C, 64.20; H, 6.52; N, 10.61. LC-MS: $\mathrm{m} / \mathrm{z}=523\left(\mathrm{MH}^{+}\right)$.

The following compounds $\mathbf{2 2} \mathbf{b}-\mathbf{d}, \mathbf{h}, \mathbf{i}$ were prepared in a same manner similar to that described for 22a.

6-Ethyl-3-(2-fluoroethoxy)- $N$-[1-(hydroxyacetyl)piperidin-4-yl]-1-methyl-4-oxo-5(2-oxo-2- phenylethyl)-4,5-dihydro-1H-pyrrolo[3,2-c]pyridine-2-carboxamide (22b)

Yield 80\%, white crystals; mp $208{ }^{\circ} \mathrm{C}$ (recrystallized from AcOEt / THF). ${ }^{1} \mathrm{H}$ NMR (DMSO- $\left.d_{6}\right) \delta 1.19(3 \mathrm{H}, \mathrm{t}, J=7.4 \mathrm{~Hz}), 1.26-1.48(2 \mathrm{H}, \mathrm{m}), 1.87(2 \mathrm{H}, \mathrm{s}), 2.59(2 \mathrm{H}$, q, $J=7.4 \mathrm{~Hz}), 2.76-2.91(1 \mathrm{H}, \mathrm{m}), 3.01-3.17(1 \mathrm{H}, \mathrm{m}), 3.57-3.73(1 \mathrm{H}, \mathrm{m}), 3.92(3 \mathrm{H}, \mathrm{s})$, 3.97-4.13 (3H, m), 4.18-4.32 (1H, m), 4.45-4.81 (5H, m), $5.59(2 \mathrm{H}, \mathrm{s}), 6.49-6.56(1 \mathrm{H}$, $\mathrm{m})$, 7.55-7.66 $(3 \mathrm{H}, \mathrm{m}), 7.69-7.78(1 \mathrm{H}, \mathrm{m}), 8.06-8.16(2 \mathrm{H}, \mathrm{m})$. Anal. calcd for $\mathrm{C}_{28} \mathrm{H}_{33} \mathrm{FN}_{4} \mathrm{O}_{6}: \mathrm{C}, 62.21 ; \mathrm{H}, 6.15 ; \mathrm{N}, 10.36$. Found: $\mathrm{C}, 62.03 ; \mathrm{H}, 6.24 ; \mathrm{N}, 10.18$. LC-MS: $\mathrm{m} / \mathrm{z}=541\left(\mathrm{MH}^{+}\right)$.

3-(2,2-Difluoroethoxy)-6-ethyl- $N$-[1-(hydroxyacetyl)piperidin-4-yl]-1-methyl-4-oxo5-(2-oxo-2-phenylethyl)-4,5-dihydro-1H-pyrrolo[3,2-c]pyridine-2-carboxamide (22c)

Yield $65 \%$, white crystals; mp $188{ }^{\circ} \mathrm{C}$ (recrystallized from acetone / $\mathrm{H}_{2} \mathrm{O}$ ). ${ }^{1} \mathrm{H}$ NMR (DMSO- $\left.d_{6}\right) \delta 1.19(3 \mathrm{H}, \mathrm{t}, J=7.4 \mathrm{~Hz}), 1.20-1.50(2 \mathrm{H}, \mathrm{m}), 1.90(2 \mathrm{H}, \mathrm{d}, J=9.9 \mathrm{~Hz})$, $2.59(2 \mathrm{H}, \mathrm{q}, J=7.4 \mathrm{~Hz}), 2.83(1 \mathrm{H}, \mathrm{t}, J=12.2 \mathrm{~Hz}), 3.09(1 \mathrm{H}, \mathrm{t}, J=11.7 \mathrm{~Hz}), 3.68(1 \mathrm{H}, \mathrm{d}$, $J=12.9 \mathrm{~Hz}), 3.90(3 \mathrm{H}, \mathrm{s}), 3.95-4.20(3 \mathrm{H}, \mathrm{m}), 4.26(1 \mathrm{H}, \mathrm{d}, J=11.7 \mathrm{~Hz}), 4.51(1 \mathrm{H}, \mathrm{t}, J=$ $5.4 \mathrm{~Hz}), 4.67(2 \mathrm{H}, \mathrm{td}, J=16.1,3.0 \mathrm{~Hz}), 5.23(1 \mathrm{H}, \mathrm{s}), 5.61(2 \mathrm{H}, \mathrm{s}), 6.33(1 \mathrm{H}, \mathrm{tt}, J=54.2$, $3.0 \mathrm{~Hz}), 7.49(1 \mathrm{H}, \mathrm{d}, J=7.8 \mathrm{~Hz}), 7.61(2 \mathrm{H}, \mathrm{t}, J=7.5 \mathrm{~Hz}), 7.73(1 \mathrm{H}, \mathrm{t}, J=7.5 \mathrm{~Hz})$, 8.10-8.12 (2H, m). Anal. calcd for $\mathrm{C}_{28} \mathrm{H}_{32} \mathrm{~F}_{2} \mathrm{~N}_{4} \mathrm{O}_{6}: \mathrm{C}, 60.21 ; \mathrm{H}, 5.77 ; \mathrm{N}, 10.03$. Found: $\mathrm{C}$, $60.23 ; \mathrm{H}, 5.78 ; \mathrm{N}, 10.01$. LC-MS: $\mathrm{m} / \mathrm{z}=559\left(\mathrm{MH}^{+}\right)$.

6-Ethyl- $N$-[1-(hydroxyacetyl)piperidin-4-yl]-1-methyl-4-oxo-5-(2-oxo-2-phenylethyl )-3-(2,2,2-trifluoroethoxy)-4,5-dihydro-1H-pyrrolo[3,2-c]pyridine-2-carboxamide (22d)

Yield 76\%, white crystals; mp $169^{\circ} \mathrm{C}$ (recrystallized from EtOH / $\mathrm{H}_{2} \mathrm{O}$ ). ${ }^{1} \mathrm{H}$ NMR $\left(\mathrm{DMSO}-d_{6}\right) \delta 1.19(3 \mathrm{H}, \mathrm{t}, J=7.3 \mathrm{~Hz}), 1.24-1.51(2 \mathrm{H}, \mathrm{m}), 1.79-1.98(2 \mathrm{H}, \mathrm{m}), 2.59(2 \mathrm{H}$, q, $J=7.3 \mathrm{~Hz}), 2.75-2.94(1 \mathrm{H}, \mathrm{m}), 2.98-3.20(1 \mathrm{H}, \mathrm{m}), 3.57-3.77(1 \mathrm{H}, \mathrm{m}), 3.86(3 \mathrm{H}, \mathrm{s})$, 3.94-4.17 (3H, m), 4.17-4.38 (1H, m), $4.53(1 \mathrm{H}, \mathrm{t}, J=5.3 \mathrm{~Hz}), 5.05(2 \mathrm{H}, \mathrm{q}, J=9.3 \mathrm{~Hz})$, 
$5.63(2 \mathrm{H}, \mathrm{s}), 6.54(1 \mathrm{H}, \mathrm{s}), 7.51(1 \mathrm{H}, \mathrm{d}, J=7.7 \mathrm{~Hz}), 7.55-7.67(2 \mathrm{H}, \mathrm{m}), 7.68-7.82(1 \mathrm{H}$, m), 8.01-8.21 (2H, m). Anal. calcd for $\mathrm{C}_{28} \mathrm{H}_{31} \mathrm{~F}_{3} \mathrm{~N}_{4} \mathrm{O}_{6}$ : C, 58.33; H, 5.42; N, 9.72 . Found: C, 58.32; H, 5.55; N, 9.63. LC-MS: $m / z=577\left(\mathrm{MH}^{+}\right)$.

\section{3,6-Diethyl- $N$-[1-(hydroxyacetyl)piperidin-4-yl]-1-methyl-4-oxo-5-(2-oxo-2-phenyl} ethyl)-4,5-dihydro-1H-pyrrolo[3,2-c]pyridine-2-carboxamide (22h)

Yield 47\%, white crystals; mp $141{ }^{\circ} \mathrm{C}$ (recrystallized from hexane / AcOEt). ${ }^{1} \mathrm{H}$ NMR (DMSO- $\left.d_{6}\right) \delta 1.06(3 \mathrm{H}, \mathrm{t}, J=7.2 \mathrm{~Hz}), 1.18(3 \mathrm{H}, \mathrm{t}, J=7.3 \mathrm{~Hz}), 1.30-1.54(2 \mathrm{H}, \mathrm{m})$, 1.81-1.93 (2H, m), 2.54-2.63 (2H, m), 2.78-2.92 (3H, m), 3.01-3.17 (1H, m), 3.59-3.73 $(4 \mathrm{H}, \mathrm{m}), 3.99-4.16(3 \mathrm{H}, \mathrm{m}), 4.20-4.31(1 \mathrm{H}, \mathrm{m}), 4.51(1 \mathrm{H}, \mathrm{t}, J=5.5 \mathrm{~Hz}), 5.58(2 \mathrm{H}, \mathrm{s})$, $6.42(1 \mathrm{H}, \mathrm{s}), 7.56-7.65(2 \mathrm{H}, \mathrm{m}), 7.69-7.77(1 \mathrm{H}, \mathrm{m}), 8.07-8.15(2 \mathrm{H}, \mathrm{m}), 8.21(1 \mathrm{H}, \mathrm{d}, J=$ 7.4 Hz). Anal. calcd for $\mathrm{C}_{28} \mathrm{H}_{34} \mathrm{~N}_{4} \mathrm{O}_{5} \cdot 0.5$ AcOEt: $\mathrm{C}, 65.44 ; \mathrm{H}, 6.96 ; \mathrm{N}, 10.17$. Found: $\mathrm{C}$, 65.46; H, 7.01; N,10.27. LC-MS: $m / z=507\left(\mathrm{MH}^{+}\right)$.

\section{$N$-[1-(Hydroxyacetyl)piperidin-4-yl]-3-methoxy-1-methyl-4-oxo-5-(2-oxo-2-phenyl} ethyl)-4,5,6,7,8,9-hexahydro-1H-pyrrolo[3,2-c]quinoline-2-carboxamide (22i)

Yield 76\%, colorless oil. ${ }^{1} \mathrm{H}$ NMR (DMSO- $\left.d_{6}\right) \delta$ 1.22-1.25 $(2 \mathrm{H}, \mathrm{m}), 1.35-1.56$ $(2 \mathrm{H}, \mathrm{m}), 1.60-1.74(4 \mathrm{H}, \mathrm{m}), 1.80-1.92(2 \mathrm{H}, \mathrm{m}), 2.83-3.22(4 \mathrm{H}, \mathrm{m}), 3.59-3.70(1 \mathrm{H}, \mathrm{m})$, $3.90(3 \mathrm{H}, \mathrm{s}), 3.98-4.12(7 \mathrm{H}, \mathrm{m}), 4.51(1 \mathrm{H}, \mathrm{t}, J=5.4 \mathrm{~Hz}), 5.63(2 \mathrm{H}, \mathrm{s}), 7.56-7.65(2 \mathrm{H}, \mathrm{m})$, 7.69-7.82 (2H, m), $8.10(2 \mathrm{H}, \mathrm{d}, J=8.3 \mathrm{~Hz})$. LC-MS: $m / z=535\left(\mathrm{MH}^{+}\right)$.

\section{$N$-[1-(Hydroxyacetyl)piperidin-4-yl]-3-methoxy-1,6-dimethyl-4-oxo-5-(2-oxo-2- phenylethyl)-4,5-dihydro-1H-pyrrolo[3,2-c]pyridine-2-carboxamide (22j)}

Acetoxyacetyl chloride $(61.4 \mu \mathrm{L}, 0.571 \mathrm{mmol})$ at $0{ }^{\circ} \mathrm{C}$ was added to a mixture of 21a (225 mg, $0.476 \mathrm{mmol})$ and $\mathrm{Et}_{3} \mathrm{~N}(198 \mu \mathrm{L}, 1.43 \mathrm{mmol})$ in $\mathrm{THF}(5 \mathrm{~mL})$ and the mixture was stirred at room temperature for $15 \mathrm{~h}$. The mixture was diluted with AcOEt, washed with water and brine, and dried over $\mathrm{MgSO}_{4}$. After removal of $\mathrm{MgSO}_{4}$ by filtration, the filtrate was concentrated in vacuo. The residue was purified by basic silica gel column (AcOEt) to give 2-[4-(\{[3-methoxy-1,6-dimethyl-4-oxo-5-(2-oxo-2-phenylethyl)-4,5-dihydro-1H-pyrrol $\mathrm{o}[3,2-c]$ - pyridin-2-yl]carbonyl $\}$ amino)piperidin-1-yl]-2-oxoethyl acetate. $8 \mathrm{M} \mathrm{NaOH}$ aq. $(0.5 \mathrm{~mL})$, THF $(2.5 \mathrm{~mL})$ and $\mathrm{EtOH}(5 \mathrm{~mL})$ were added to a mixture of the compound obtained above and stirred at room temperature for $2 \mathrm{~h}$. The mixture was neutralized with $1 \mathrm{M} \mathrm{HCl}$ aq. and diluted with water, and extracted with AcOEt / THF. The organic layer was washed with water and brine and dried over $\mathrm{MgSO}_{4}$. After removal of $\mathrm{MgSO}_{4}$ by filtration, the filtrate was concentrated in vacuo. The residue was purified by basic 
silica gel column chromatography (AcOEt) to give the title compound (156 mg, 66\%) as a white solid; mp $237{ }^{\circ} \mathrm{C}$ (recrystallized from hexane / AcOEt / THF). ${ }^{1} \mathrm{H}$ NMR $\left(\mathrm{DMSO}_{6}\right) \delta$ 1.32-1.61 $(2 \mathrm{H}, \mathrm{m}), 1.79-1.93(2 \mathrm{H}, \mathrm{m}), 2.28(3 \mathrm{H}, \mathrm{s}), 2.82-2.98(1 \mathrm{H}, \mathrm{m})$, 3.04-3.20 $(1 \mathrm{H}, \mathrm{m}), 3.57-3.71(1 \mathrm{H}, \mathrm{m}), 3.86(3 \mathrm{H}, \mathrm{s}), 3.96-4.25(7 \mathrm{H}, \mathrm{m}), 4.50(1 \mathrm{H}, \mathrm{d}, J=$ $5.3 \mathrm{~Hz}), 5.61(2 \mathrm{H}, \mathrm{s}), 6.58(1 \mathrm{H}, \mathrm{s}), 7.55-7.67(3 \mathrm{H}, \mathrm{m}), 7.69-7.78(1 \mathrm{H}, \mathrm{m}), 8.07-8.16(2 \mathrm{H}$, m). Anal. calcd for $\mathrm{C}_{26} \mathrm{H}_{30} \mathrm{~N}_{4} \mathrm{O}_{6}: \mathrm{C}, 63.15 ; \mathrm{H}, 6.11 ; \mathrm{N}, 11.33$. Found: $\mathrm{C}, 63.03 ; \mathrm{H}, 6.15$; $\mathrm{N}$, 11.07. LC-MS: $\mathrm{m} / \mathrm{z}=495\left(\mathrm{MH}^{+}\right)$.

\section{6-Ethyl- $N$-[1-(hydroxyacetyl)piperidin-4-yl]-3-methoxy-1-methyl-4-oxo-5-(2-oxo-2- phenylethyl)-4,5-dihydro-1H-pyrrolo[3,2-c]pyridine-2-carboxamide (22e)}

In the same manner as in the preparation of $\mathbf{2 2} \mathbf{j}$, the title compound $(61.2 \mathrm{mg}$, $65 \%$ ) was obtained as a white powder from $21 \mathrm{~b}(90.0 \mathrm{mg}, 0.185 \mathrm{mmol})$; mp $146{ }^{\circ} \mathrm{C}$ (recrystallized from AcOEt). ${ }^{1} \mathrm{H}$ NMR (DMSO- $\left.d_{6}\right) \delta 1.13-1.23(3 \mathrm{H}, \mathrm{m}), 1.31-1.59(2 \mathrm{H}$, m), 1.80-1.94 (2H, m), $2.58(2 \mathrm{H}, \mathrm{q}, J=7.4 \mathrm{~Hz}), 2.83-2.99(1 \mathrm{H}, \mathrm{m}), 3.04-3.21(1 \mathrm{H}, \mathrm{m})$, 3.59-3.70 (1H, m), $3.89(3 \mathrm{H}, \mathrm{s}), 3.97-4.26(7 \mathrm{H}, \mathrm{m}), 4.49(1 \mathrm{H}, \mathrm{t}, J=5.4 \mathrm{~Hz}), 5.59(2 \mathrm{H}, \mathrm{s})$, $6.49(1 \mathrm{H}, \mathrm{s}), 7.56-7.67(3 \mathrm{H}, \mathrm{m}), 7.70-7.78(1 \mathrm{H}, \mathrm{m}), 8.06-8.15(2 \mathrm{H}, \mathrm{m})$. Anal. calcd for $\mathrm{C}_{27} \mathrm{H}_{32} \mathrm{~N}_{4} \mathrm{O}_{6}: \mathrm{C}, 63.77 ; \mathrm{H}, 6.34 ; \mathrm{N}, 11.02$. Found: $\mathrm{C}, 63.58 ; \mathrm{H}, 6.31 ; \mathrm{N}, 10.87$. LC-MS: $\mathrm{m} / \mathrm{z}=509\left(\mathrm{MH}^{+}\right)$.

\section{2-(4-Aminopiperidin-1-yl)-2-oxoethanol hydrochloride (24)}

Acetoxyacetyl chloride $(3.10 \mathrm{~mL}, 28.8 \mathrm{mmol})$ was added dropwise at $0{ }^{\circ} \mathrm{C}$ to a mixture of 23 (4.80 g, $24.0 \mathrm{mmol})$ and $\mathrm{Et}_{3} \mathrm{~N}(9.96 \mathrm{~mL}, 71.9 \mathrm{mmol})$ in THF (50 mL) and the mixture was stirred for $2 \mathrm{~h}$. The mixture was diluted with AcOEt, washed with water and brine, dried over $\mathrm{MgSO}_{4}$, and concentrated in vacuo. The residual solid was collected by filtration and washed with hexane / AcOEt solution. A mixture of the solid obtained, $8 \mathrm{M} \mathrm{NaOH}$ aq. $(5 \mathrm{~mL})$ and $\mathrm{EtOH}(35 \mathrm{~mL})$ was stirred at room temperature for $2 \mathrm{~h}$. The mixture was acidified with $6 \mathrm{M} \mathrm{HCl}$ aq. and concentrated in vacuo. The residue was dissolved in AcOEt $(30 \mathrm{~mL})$ and $4 \mathrm{M} \mathrm{HCl}$ in AcOEt $(30 \mathrm{~mL})$ was added. After stirring at room temperature for $6 \mathrm{~h}$, the resulting solid was collected by filtration and washed with AcOEt to give the title compound (3.73 g, 80\%) as a white solid. ${ }^{1} \mathrm{H}$ NMR $\left(\mathrm{DMSO}_{6}\right) \delta 1.31-1.51(2 \mathrm{H}, \mathrm{m}), 1.93(2 \mathrm{H}, \mathrm{d}, J=12.9 \mathrm{~Hz}), 2.69(1 \mathrm{H}, \mathrm{t}, J=12.2 \mathrm{~Hz})$, $3.00(1 \mathrm{H}, \mathrm{t}, J=12.3 \mathrm{~Hz}), 3.10-3.30(1 \mathrm{H}, \mathrm{m}), 3.73(1 \mathrm{H}, \mathrm{d}, J=13.8 \mathrm{~Hz}), 4.08(2 \mathrm{H}, \mathrm{q}, J=$ $13.9 \mathrm{~Hz}), 4.33(1 \mathrm{H}, \mathrm{d}, J=12.9 \mathrm{~Hz}), 8.38(3 \mathrm{H}$, br s). 


\section{Experimental section of chapter III}

\section{Propanimidamide hydrochloride (31)}

To a solution of propionitrile $(10 \mathrm{~g}, 142 \mathrm{mmol})$ in EtOH $(8.4 \mathrm{~mL})$ was blown hydrogen chloride gas (total amount increase $7.9 \mathrm{~g}$ ), and the mixture was stirred at room temperature for $21.5 \mathrm{~h}$. The mixture was concentrated in vacuo, the residue was suspended in $\mathrm{EtOH}(5.5 \mathrm{~mL})$, and cooled to $-10^{\circ} \mathrm{C}$. To the suspension was added $8 \mathrm{M}$ $\mathrm{MeOH}$ solution of ammonia $(17.8 \mathrm{~mL})$, and the mixture was stirred at room temperature for $28 \mathrm{~h}$. The insoluble material was filtered off, and the filtrate was concentrated in vacuo to give the title compound $(10.8 \mathrm{~g}, 70 \%)$ as a white solid. ${ }^{1} \mathrm{H}$ NMR (DMSO- $\left.d_{6}\right) \delta$ $1.17(3 \mathrm{H}, \mathrm{t}, J=7.6 \mathrm{~Hz}), 2.40(2 \mathrm{H}, \mathrm{q}, J=7.7 \mathrm{~Hz}), 8.77$ (2H, br s), 9.07 ( $2 \mathrm{H}$, br s).

\section{2-Ethylpyrimidine-4,6-diol (32)}

To a solution of $31(11 \mathrm{~g}, 99 \mathrm{mmol})$ in $\mathrm{MeOH}(20 \mathrm{~mL})$ was added $28 \%$ solution of $\mathrm{NaOMe}$ in $\mathrm{MeOH}$ (57 g, $296 \mathrm{mmol}$ ), and the mixture was stirred at room temperature for $10 \mathrm{~min}$. Diethyl malonate $(15 \mathrm{~mL}, 99 \mathrm{mmol})$ was added dropwise, and the mixture was further stirred at room temperature for $16 \mathrm{~h}$. The reaction mixture was concentrated in vacuo, the residue was dissolved in water and acidified with conc. $\mathrm{HCl}$. The precipitated solid was collected by filtration, washed with water and $\mathrm{Et}_{2} \mathrm{O}$ to give the title compound $(9.3 \mathrm{~g}, 67 \%)$ as a white solid. ${ }^{1} \mathrm{H}$ NMR (DMSO- $\left.d_{6}\right) \delta 1.16(3 \mathrm{H}, \mathrm{t}, J=$ 7.6 Hz), 2.36-2.60 (2 H, m), 5.03 (1 H, s), 11.62 (2 H, br s).

\section{Ethyl 4,6-dichloro-2-ethylpyrimidine-5-carboxylate (29a)}

DMF $(5.5 \mathrm{~mL})$ was added dropwise to $\mathrm{POCl}_{3}(60 \mathrm{~mL}, 641 \mathrm{mmol})$ at $0{ }^{\circ} \mathrm{C}$, the mixture was stirred at $0{ }^{\circ} \mathrm{C}$ for $1 \mathrm{~h} .32(10 \mathrm{~g}, 71 \mathrm{mmol})$ was added, the mixture was stirred at room temperature for $1 \mathrm{~h}$ and heated under reflux for $16 \mathrm{~h}$. The mixture was concentrated in vacuo, the residue was added to ice water by small portions. The mixture was extracted three times with a mixed solvent of $\mathrm{Et}_{2} \mathrm{O} / \mathrm{AcOEt}$. The extracts were combined, washed with brine, dried over $\mathrm{MgSO}_{4}$ and concentrated in vacuo. The residue was suspended in AcOEt, and the insoluble material was filtered off. The filtrate was concentrated in vacuo, and the residue was purified by silica gel column chromatography (hexane/AcOEt $=99 / 1$ to 9/1) to give 4,6-dichloro-2-ethylpyrimidine-5-carbaldehyde (10.6 g, 73\%) as a pale yellow powder. To a mixture of obtained aldehyde (11 g, $52 \mathrm{mmol})$, amidosulfuric acid (7.0 g, $72 \mathrm{mmol})$, tert-butanol $(100 \mathrm{~mL})$ and water $(40 \mathrm{~mL})$ was added dropwise a solution of sodium chlorite $(6.6 \mathrm{~g}, 72 \mathrm{mmol})$ in water $(20 \mathrm{~mL})$. After stirring at room temperature for 30 
min, the reaction mixture was diluted with water, and extracted twice with AcOEt. The extracts were combined, washed with water and brine, dried over $\mathrm{MgSO}_{4}$ and concentrated in vacuo. The residue was dissolved in THF $(60 \mathrm{~mL})$, oxalyl chloride $(9.7$ $\mathrm{mL}, 111 \mathrm{mmol}$ ) was added dropwise at $0{ }^{\circ} \mathrm{C}$, then DMF (1 drop) was added. After stirring at room temperature for $3 \mathrm{~h}$, the reaction mixture was concentrated in vacuo. EtOH $(60 \mathrm{~mL})$ and $\mathrm{Et}_{3} \mathrm{~N}(16 \mathrm{~mL}, 111 \mathrm{mmol})$ were added under ice-cooling, and the mixture was stirred at room temperature for $3 \mathrm{~h}$. The reaction mixture was diluted with saturated $\mathrm{NaHCO}_{3}$ aq. and water, and extracted twice with AcOEt. The extracts were combined, washed with brine, dried over $\mathrm{MgSO}_{4}$ and concentrated in vacuo. The residue was purified by silica gel column chromatography (hexane/AcOEt $=97 / 3$ to $17 / 3)$ to give the title compound $(6.7 \mathrm{~g}, 53 \%)$ as pale yellow oil. ${ }^{1} \mathrm{H}$ NMR $\left(\mathrm{CDCl}_{3}\right) \delta$ 1.31-1.48 (6 H, m), $2.97(2 \mathrm{H}, \mathrm{q}, J=7.6 \mathrm{~Hz}), 4.48(2 \mathrm{H}, \mathrm{q}, J=7.2 \mathrm{~Hz})$.

\section{Ethyl 4-chloro-6-[(2-ethoxy-2-oxoethyl)(methyl)amino]-2-ethylpyrimidine-5- carboxylate (28a)}

A solution of 29a (425 mg, $1.7 \mathrm{mmol}$ ), ethyl sarcosinate hydrochloride (262 mg, $1.7 \mathrm{mmol})$ and $\mathrm{Et}_{3} \mathrm{~N}(0.57 \mathrm{~mL}, 4.1 \mathrm{mmol})$ in THF $(13 \mathrm{~mL})$ was stirred at room temperature for $19.5 \mathrm{~h}$. The reaction mixture was diluted with saturated $\mathrm{NaHCO}_{3}$ aq., and extracted twice with AcOEt. The extracts were combined, washed with brine, dried over $\mathrm{MgSO}_{4}$ and concentrated in vacuo to give the title compound (560 mg, 99\%) as colorless oil. ${ }^{1} \mathrm{H}$ NMR $\left(\mathrm{CDCl}_{3}\right) \delta 1.17-1.32(6 \mathrm{H}, \mathrm{m}), 1.41(3 \mathrm{H}, \mathrm{t}, J=7.2 \mathrm{~Hz}), 2.72(2 \mathrm{H}$, q, $J=7.6 \mathrm{~Hz}), 3.11(3 \mathrm{H}, \mathrm{s}), 4.21(2 \mathrm{H}, \mathrm{q}, J=7.1 \mathrm{~Hz}), 4.28(2 \mathrm{H}, \mathrm{s}), 4.40(2 \mathrm{H}, \mathrm{q}, J=7.2$ $\mathrm{Hz})$.

\section{Ethyl 4-chloro-2-ethyl-5-hydroxy-7-methyl-7H-pyrrolo[2,3-d]pyrimidine-6- carboxylate (27a)}

A solution of 28a ( $810 \mathrm{mg}, 2.5 \mathrm{mmol}$ ) and $20 \%$ solution of NaOEt in EtOH (836 $\mathrm{mg}, 2.5 \mathrm{mmol})$ in EtOH $(25 \mathrm{~mL})$ was stirred at room temperature for $15 \mathrm{~min}$. The reaction mixture was diluted with water, neutralized with $1 \mathrm{M} \mathrm{HCl}$ aq., and stirred at 0 ${ }^{\circ} \mathrm{C}$ for $30 \mathrm{~min}$. The precipitated solid was collected by filtration, washed with water, and dried in vacuo to give the title compound $(637 \mathrm{mg}, 91 \%)$ as a pale yellow powder. ${ }^{1} \mathrm{H}$ NMR (DMSO- $\left.d_{6}\right) \delta 1.21-1.43$ (6 H, m), $2.90(2 \mathrm{H}, \mathrm{q}, J=7.6 \mathrm{~Hz}), 3.88(3 \mathrm{H}, \mathrm{s}), 4.37$ $(2 \mathrm{H}, \mathrm{q}, J=7.0 \mathrm{~Hz}), 9.50(1 \mathrm{H}$, br s$)$. 
Ethyl 4-chloro-2-ethyl-7-methyl-5-(2,2,2-trifluoroethoxy)-7H-pyrrolo[2,3-d] pyrimidine-6-carboxylate (33)

To a mixture of 27a $(1.0 \mathrm{~g}, 3.7 \mathrm{mmol})$ and $\mathrm{Cs}_{2} \mathrm{CO}_{3}(1.3 \mathrm{~g}, 4.0 \mathrm{mmol})$ in DMF (27 $\mathrm{mL})$ was added dropwise 2,2,2-trifluoroethyl trifluoromethanesulfonate $(0.64 \mathrm{~mL}, 4.4$ mmol) at $0{ }^{\circ} \mathrm{C}$, and the mixture was stirred at room temperature for $4 \mathrm{~h}$. The mixture was diluted with water, and the precipitated solid was collected by filtration. The obtained solid was washed with water, and dried in vacuo to give the title compound $(1.2 \mathrm{~g}, 91 \%)$ as a pale yellow powder. ${ }^{1} \mathrm{H}$ NMR $\left(\mathrm{CDCl}_{3}\right) \delta 1.34-1.49(6 \mathrm{H}, \mathrm{m}), 3.02(2 \mathrm{H}$, q, $J=7.6 \mathrm{~Hz}), 4.06(3 \mathrm{H}, \mathrm{s}), 4.39-4.57(4 \mathrm{H}, \mathrm{m})$.

\section{Ethyl 2-ethyl-7-methyl-4-oxo-5-(2,2,2-trifluoroethoxy)-4,7-dihydro-3H-pyrrolo [2,3-d]pyrimidine-6-carboxylate (34)}

A solution of 33 (1.2 g, $3.3 \mathrm{mmol})$ and AcONa (272 mg, $3.3 \mathrm{mmol})$ in $\mathrm{AcOH}$ (20 $\mathrm{mL}$ ) was heated under reflux for $2.5 \mathrm{~h}$. After allowing to cool to room temperature, the reaction mixture was poured into water, and the precipitated solid was collected by filtration. The obtained solid was washed with water, and dried in vacuo to give the title compound $(1.10 \mathrm{~g}, 96 \%)$ as a pale yellow solid. ${ }^{1} \mathrm{H}$ NMR (DMSO- $\left.d_{6}\right) \delta 1.16-1.37$ $(6 \mathrm{H}, \mathrm{m}), 2.63(2 \mathrm{H}, \mathrm{q}, J=7.6 \mathrm{~Hz}), 3.83(3 \mathrm{H}, \mathrm{s}), 4.25(2 \mathrm{H}, \mathrm{q}, J=7.1 \mathrm{~Hz}), 5.01(2 \mathrm{H}, \mathrm{q}$, $J=9.4 \mathrm{~Hz}), 12.02(1 \mathrm{H}$, br s).

\section{2-Ethyl-7-methyl-4-oxo-5-(2,2,2-trifluoroethoxy)-4,7-dihydro-3H-pyrrolo[2,3-d] pyrimidine-6-carboxylic acid (36a)}

A mixture of $34(4.0 \mathrm{~g}, 11.5 \mathrm{mmol})$ and $8 \mathrm{M} \mathrm{NaOH}$ aq. $(8 \mathrm{~mL})$ in $\mathrm{EtOH}$ was stirred at room temperature for $15 \mathrm{~min}$ and at $60{ }^{\circ} \mathrm{C}$ for $4 \mathrm{~h}$. After cooling at $0{ }^{\circ} \mathrm{C}$, the mixture was neutralized with $6 \mathrm{M} \mathrm{HCl}$ aq.. The solvent was evaporated, the precipitate was collected by filtration washed with water, and dried in vacuo to give the title compound $(2.91 \mathrm{~g}, 79 \%)$ as a pale yellow powder. ${ }^{1} \mathrm{H}$ NMR (DMSO- $\left.d_{6}\right) \delta 1.22(3 \mathrm{H}, \mathrm{t}, J$ $=7.6 \mathrm{~Hz}), 2.62(2 \mathrm{H}, \mathrm{q}, J=7.4 \mathrm{~Hz}), 3.83(3 \mathrm{H}, \mathrm{s}), 5.01(2 \mathrm{H}, \mathrm{q}, J=9.3 \mathrm{~Hz}), 12.07(1 \mathrm{H}$, s), $12.71(1 \mathrm{H}$, br s).

\section{Ethyl 2-ethyl-7-methyl-4-oxo-3-(2-oxo-2-phenylethyl)-5-(2,2,2-trifluoroethoxy)-} 4,7-dihydro-3H-pyrrolo[2,3-d]pyrimidine-6-carboxylate (35)

To a suspension of 34 (124 mg, $0.357 \mathrm{mmol})$ in DME (4 mL) / DMF (1mL) was added portionwise potassium tert-butoxide $(44 \mathrm{mg}, 0.462 \mathrm{mmol})$ and the mixture was stirred at $0{ }^{\circ} \mathrm{C}$ for $15 \mathrm{~min}$. $\mathrm{LiBr}(62 \mathrm{mg}, 0.714 \mathrm{mmol})$ was added, and the mixture was stirred at room temperature for $15 \mathrm{~min}$. Phenacyl bromide (142 $\mathrm{mg}, 0.714 \mathrm{mmol}$ ) was 
added, and the mixture was stirred at $60^{\circ} \mathrm{C}$ for $16 \mathrm{~h}$. The mixture was diluted with brine, and extracted twice with AcOEt. The combined organic layer was dried over $\mathrm{MgSO}_{4}$ and concentrated in vacuo. The residue was purified by silica gel column chromatography (hexane/AcOEt $=97 / 3$ to $7 / 3$ ) to give the title compound ( $95 \mathrm{mg}, 57 \%$ ) as a yellow solid. ${ }^{1} \mathrm{H}$ NMR (DMSO- $\left.d_{6}\right) \delta 1.17-1.36(6 \mathrm{H}, \mathrm{m}), 2.74(2 \mathrm{H}, \mathrm{q}, J=7.2 \mathrm{~Hz})$, $3.90(3 \mathrm{H}, \mathrm{s}), 4.27(2 \mathrm{H}, \mathrm{q}, J=7.2 \mathrm{~Hz}), 4.91(2 \mathrm{H}, \mathrm{q}, J=9.1 \mathrm{~Hz}), 5.72(2 \mathrm{H}, \mathrm{s})$, 7.56-7.68 (2 H, m), 7.69-7.83 (1 H, m), 8.03-8.24 (2 H, m).

\section{Ethyl 6-ethyl-2-oxo-1,2-dihydropyridine-3-carboxylate (40)}

A mixture of 16a (32.1 g, $140 \mathrm{mmol}), \mathrm{Et}_{3} \mathrm{~N}$ (39 mL, $\left.280 \mathrm{mmol}\right), 10 \% \mathrm{Pd}-\mathrm{C}(1.60$ $\mathrm{g})$ in $\mathrm{EtOH}(180 \mathrm{~mL}) / \mathrm{THF}(180 \mathrm{~mL})$ was stirred at room temperature for $5 \mathrm{~h}$ under $\mathrm{H}_{2}$ atmosphere. The catalyst was filtered off, washed with $\mathrm{MeOH}$, and the filtrate was concentrated in vacuo. To the residue was added AcOEt, the insoluble material was filtered off, and washed with AcOEt. The filtrate was washed with water containing 6M $\mathrm{HCl}$ aq. $(1 \mathrm{ml})$, and the aqueous layer was extracted with AcOEt. The combined organic layer was washed with brine, dried over $\mathrm{MgSO}_{4}$ and concentrated in vacuo. The precipitate was collected by filtration, and washed with mixed solvent of hexane/AcOEt to give the title compound $(24.7 \mathrm{~g}, 90 \%)$ as a brown powder. ${ }^{1} \mathrm{H} \mathrm{NMR}\left(\mathrm{CDCl}_{3}\right) \delta 1.32$ $(3 \mathrm{H}, \mathrm{t}, J=7.6 \mathrm{~Hz}), 1.38(3 \mathrm{H}, \mathrm{t}, J=7.2 \mathrm{~Hz}), 2.74(2 \mathrm{H}, \mathrm{q}, J=7.6 \mathrm{~Hz}), 4.37(2 \mathrm{H}, \mathrm{q}, J=$ $7.2 \mathrm{~Hz}), 6.29(1 \mathrm{H}, \mathrm{d}, J=7.2 \mathrm{~Hz}), 8.18(1 \mathrm{H}, \mathrm{d}, J=7.6 \mathrm{~Hz}), 12.50(1 \mathrm{H}, \mathrm{br} \mathrm{s})$.

\section{Ethyl 5-bromo-6-ethyl-2-oxo-1,2-dihydropyridine-3-carboxylate (41)}

To a solution of $40(17.5 \mathrm{~g}, 89.7 \mathrm{mmol})$ in DMF $(100 \mathrm{~mL})$ was added $\mathrm{N}$-bromosuccinimide $(16.0 \mathrm{~g}, 89.9 \mathrm{mmol})$ at $0{ }^{\circ} \mathrm{C}$, and the mixture was stirred at room temperature for $1 \mathrm{~h}$. To the mixture was added dropwise water $(250 \mathrm{~mL})$ at $0{ }^{\circ} \mathrm{C}$, and the mixture was stirred at room temperature for $30 \mathrm{~min}$. The precipitate was collected by filtration, and washed with water to give the title compound $(21.2 \mathrm{~g}, 86 \%)$ as a brown powder. ${ }^{1} \mathrm{H}$ NMR (DMSO- $\left.d_{6}\right) \delta 1.14(3 \mathrm{H}, \mathrm{t}, J=7.6 \mathrm{~Hz}), 1.26(3 \mathrm{H}, \mathrm{t}, J=7.2 \mathrm{~Hz}), 2.64$ $(2 \mathrm{H}, \mathrm{q}, J=7.6 \mathrm{~Hz}), 4.20(2 \mathrm{H}, \mathrm{q}, J=7.2 \mathrm{~Hz}), 8.06(1 \mathrm{H}, \mathrm{s}), 12.42(1 \mathrm{H}, \mathrm{br} \mathrm{s})$.

\section{Ethyl 5-bromo-2-chloro-6-ethylpyridine-3-carboxylate (29b)}

A mixture of $41(28.0 \mathrm{~g}, 102 \mathrm{mmol})$ and $\mathrm{POCl}_{3}(28 \mathrm{~mL}, 309 \mathrm{mmol})$ was heated under reflux for $12 \mathrm{~h}$. The mixture was concentrated in vacuo, ice water $(100 \mathrm{~mL})$ was added at $0{ }^{\circ} \mathrm{C}$, and the mixture was extracted with AcOEt $(100 \mathrm{~mL} \times 3)$. The extract was washed successively with saturated $\mathrm{NaHCO}_{3}$ aq. $(50 \mathrm{~mL})$ and brine, dried over $\mathrm{MgSO}_{4}$ and concentrated in vacuo. The residue was purified by silica gel column 
chromatography (hexane/AcOEt $=99 / 1$ to $9 / 1$ ) to give the title compound $(22.8 \mathrm{~g}, 76 \%$ ) as pale yellow oil. ${ }^{1} \mathrm{H}$ NMR (DMSO- $\left.d_{6}\right) \delta 1.22(3 \mathrm{H}, \mathrm{t}, J=7.5 \mathrm{~Hz}), 1.33(3 \mathrm{H}, \mathrm{t}, J=7.2$ $\mathrm{Hz}), 2.91(2 \mathrm{H}, \mathrm{q}, J=7.5 \mathrm{~Hz}), 4.34(2 \mathrm{H}, \mathrm{q}, J=7.2 \mathrm{~Hz}), 8.42(1 \mathrm{H}, \mathrm{s})$.

\section{Ethyl 5-bromo-6-ethyl-3-hydroxy-1-methyl-1H-pyrrolo[2,3-b]pyridine-2- carboxylate (27b)}

A mixture of 29b (22.8 g, $78.0 \mathrm{mmol})$, ethyl sarcosinate hydrochloride (18.0 g, $117 \mathrm{mmol}), \mathrm{Et}_{3} \mathrm{~N}(54 \mathrm{~mL}, 387 \mathrm{mmol})$ and $\mathrm{EtOH}(200 \mathrm{~mL})$ was heated under reflux for $22 \mathrm{~h}$. Then, ethyl sarcosinate hydrochloride $(6.00 \mathrm{~g}, 39.1 \mathrm{mmol})$ and $\mathrm{Et}_{3} \mathrm{~N}(22 \mathrm{~mL}, 158$ mmol) were added, and the mixture was heated under reflux for $17 \mathrm{~h}$. To the reaction mixture was added water $(250 \mathrm{~mL})$, and the mixture was extracted three times with AcOEt $(300 \mathrm{~mL})$. The extract was washed successively with water $(100 \mathrm{~mL})$ and brine $(100 \mathrm{~mL})$, and dried over $\mathrm{MgSO}_{4}$ and concentrated in vacuo. To the residue were added EtOH $(200 \mathrm{~mL})$ and a $20 \%$ solution of NaOEt in EtOH (32.0 g, $94.0 \mathrm{mmol})$, and the mixture was stirred at room temperature for $1 \mathrm{~h}$. The mixture was concentrated in vacuo, diluted with water $(250 \mathrm{~mL})$, and the mixture was acidified with $5 \mathrm{M} \mathrm{HCl}$ aq. $(20 \mathrm{~mL})$. The precipitate was collected by filtration, and washed with water to give the title compound (18.8 g, 73\%) as a pale orange solid. ${ }^{1} \mathrm{H}$ NMR (DMSO- $\left.d_{6}\right) \delta 1.27(3 \mathrm{H}, \mathrm{t}, J=$ $7.6 \mathrm{~Hz}), 1.33(3 \mathrm{H}, \mathrm{t}, J=7.1 \mathrm{~Hz}), 2.96(2 \mathrm{H}, \mathrm{q}, J=7.6 \mathrm{~Hz}), 3.88(3 \mathrm{H}, \mathrm{s}), 4.33(2 \mathrm{H}, \mathrm{q}, J$ $=7.1 \mathrm{~Hz}), 8.36(1 \mathrm{H}, \mathrm{s}), 9.76(1 \mathrm{H}$, br s $)$.

\section{Ethyl 5-bromo-6-ethyl-1-methyl-3-(2,2,2-trifluoroethoxy)-1H-pyrrolo[2,3-b] pyridine-2-carboxylate (42)}

In the same manner as in the preparation of 33 , the title compound $(1.80 \mathrm{~g}, 96 \%)$ was obtained as a pale yellow powder from $27 \mathbf{b}(1.50 \mathrm{~g}, 4.58 \mathrm{mmol}) .{ }^{1} \mathrm{H}$ NMR $\left(\mathrm{DMSO}-d_{6}\right) \delta 1.22-1.41(6 \mathrm{H}, \mathrm{m}), 3.00(2 \mathrm{H}, \mathrm{q}, J=7.4 \mathrm{~Hz}), 3.96(3 \mathrm{H}, \mathrm{s}), 4.35(2 \mathrm{H}, \mathrm{q}, J$ $=7.1 \mathrm{~Hz}), 4.86(2 \mathrm{H}, \mathrm{q}, J=9.1 \mathrm{~Hz}), 8.36(1 \mathrm{H}, \mathrm{s})$.

\section{Ethyl 5-amino-6-ethyl-1-methyl-3-(2,2,2-trifluoroethoxy)-1H-pyrrolo[2,3-b] pyridine-2-carboxylate (43)}

To a mixture of $42(2.53 \mathrm{~g}, 6.18 \mathrm{mmol})$, benzophenoneimine $(1.5 \mathrm{~mL}, 8.94 \mathrm{mmol})$, $\mathrm{Cs}_{2} \mathrm{CO}_{3}(3.98 \mathrm{~g}, 12.2 \mathrm{mmol})$ and toluene $(30 \mathrm{~mL})$ were added $\mathrm{Pd}_{2}(\mathrm{dba})_{3}(389 \mathrm{mg}, 0.425$ mmol) and xantphos (499 mg, $0.862 \mathrm{mmol}$ ), and the mixture was stirred at $100{ }^{\circ} \mathrm{C}$ for $22 \mathrm{~h}$ under Ar atmosphere. The mixture was filtered through celite pad, and washed with AcOEt. The filtrate was washed with water $(20 \mathrm{~mL})$ and brine $(10 \mathrm{~mL})$, dried over $\mathrm{MgSO}_{4}$ and concentrated in vacuo. The residue was purified by silica gel column 
chromatography (hexane/AcOEt $=99 / 1$ to 9/1) to give crude ethyl 5-[(diphenylmethylidene)amino]-6-ethyl-1-methyl-3-(2,2,2-trifluoroethoxy)-1H-pyrrolo $[2,3-b]$ pyridine-2-carboxylate. The obtained crude compound was dissolved in THF (20 $\mathrm{mL}$ ), then $2 \mathrm{M} \mathrm{HCl}$ aq. ( $5 \mathrm{~mL}$ ) was added, and the mixture was stirred at room temperature for $1 \mathrm{~h}$. To the mixture was added aqueous $\mathrm{NaHCO}_{3}$ solution (40 mL), and the mixture was extracted three times with mixed solution of AcOEt/THF (50 mL). The extract was washed with brine $(20 \mathrm{~mL})$, dried over $\mathrm{MgSO}_{4}$ and concentrated in vacuo. The residue was purified by silica gel column chromatography (hexane/AcOEt $=99 / 1$ to $2 / 1)$ to give the title compound $\left(1.95 \mathrm{~g}, 91 \%\right.$ ) as a yellow powder. ${ }^{1} \mathrm{H}$ NMR (DMSO- $d_{6}$ ) $\delta 1.25(3 \mathrm{H}, \mathrm{t}, J=7.4 \mathrm{~Hz}), 1.34(3 \mathrm{H}, \mathrm{t}, J=7.1 \mathrm{~Hz}), 2.75(2 \mathrm{H}, \mathrm{q}, J=7.4 \mathrm{~Hz}), 3.91(3 \mathrm{H}$, s), $4.32(2 \mathrm{H}, \mathrm{q}, J=7.1 \mathrm{~Hz}), 4.66(2 \mathrm{H}, \mathrm{q}, J=9.1 \mathrm{~Hz}), 4.86(2 \mathrm{H}, \mathrm{s}), 7.16(1 \mathrm{H}, \mathrm{s})$.

\section{Ethyl 6-ethyl-1-methyl-5-[(phenylcarbonyl)amino]-3-(2,2,2-trifluoroethoxy)-1H- pyrrolo[2,3-b]pyridine-2-carboxylate (44)}

To a mixture of $43(135 \mathrm{mg}, 0.391 \mathrm{mmol})$, pyridine $(63.4 \mu \mathrm{L}, 0.784 \mathrm{mmol})$ and THF (3 mL) was added benzoyl chloride $(54.4 \mu \mathrm{L}, 0.469 \mathrm{mmol})$ at $0{ }^{\circ} \mathrm{C}$, and the mixture was stirred at room temperature for $1.5 \mathrm{~h}$. To the reaction mixture was added water $(5 \mathrm{~mL})$, and the mixture was extracted four times with AcOEt $(5 \mathrm{~mL})$. The extracts were combined, dried over $\mathrm{MgSO}_{4}$ and concentrated in vacuo. The precipitate was collected by filtration to give the title compound (140 mg, 80\%) as a white powder. The filtrate was concentrated in vacuo, and the residue was purified by basic silica gel column chromatography (hexane/AcOEt $=49 / 1$ to $2 / 1$ ) to give the title compound (24.9 $\mathrm{mg}, 14 \%)$ as a white powder. ${ }^{1} \mathrm{H}$ NMR (DMSO- $\left.d_{6}\right) \delta 1.25(3 \mathrm{H}, \mathrm{t}, J=7.4 \mathrm{~Hz}), 1.36(3 \mathrm{H}$, t, $J=7.1 \mathrm{~Hz}), 2.89(2 \mathrm{H}, \mathrm{q}, J=7.4 \mathrm{~Hz}), 4.01(3 \mathrm{H}, \mathrm{s}), 4.37(2 \mathrm{H}, \mathrm{q}, J=7.1 \mathrm{~Hz}), 4.82(2$ $\mathrm{H}, \mathrm{q}, J=9.1 \mathrm{~Hz}), 7.46-7.72(3 \mathrm{H}, \mathrm{m}), 7.90-8.13(3 \mathrm{H}, \mathrm{m}), 10.13(1 \mathrm{H}, \mathrm{s})$.

\section{6-Ethyl-1-methyl-5-(2-oxo-2-phenylethyl)-3-(2,2,2-trifluoroethoxy)-1H-pyrrolo[2,3- b]pyridine-2-carboxylic acid (26b)}

To a mixture of sodium tert-butoxide (264 mg, $2.75 \mathrm{mmol}), \mathrm{Pd}(\mathrm{OAc})_{2}(25.9 \mathrm{mg}$, $0.115 \mathrm{mmol}$ ), 2-(dicyclohexylphosphino)-2'-methylbiphenyl (86.1 $\mathrm{mg}, 0.236 \mathrm{mmol}$ ) and toluene $(6 \mathrm{~mL})$ were added a solution of $42(450 \mathrm{mg}, 1.10 \mathrm{mmol})$ and acetophenone $(0.256 \mathrm{~mL}, 2.20 \mathrm{mmol})$ in toluene $(4 \mathrm{~mL})$, and the mixture was stirred at $70{ }^{\circ} \mathrm{C}$ for $17 \mathrm{~h}$. After allowing to cool to room temperature, $1 \mathrm{M} \mathrm{NaOH}$ aq. $(3 \mathrm{~mL})$ and $\mathrm{EtOH}(5 \mathrm{~mL})$ were added, and the mixture was stirred at $50{ }^{\circ} \mathrm{C}$ for $2 \mathrm{~h}$. To the reaction mixture was added aqueous $\mathrm{NH}_{4} \mathrm{Cl}$ solution $(30 \mathrm{~mL})$, and the mixture was extracted four times with AcOEt $(20 \mathrm{~mL})$. The extracts were combined, washed with brine $(10 \mathrm{~mL})$, dried over 
anhydrous $\mathrm{MgSO}_{4}$ and concentrated in vacuo. The residue was purified by silica gel column chromatography (hexane/AcOEt $=1 / 1$ to $\mathrm{AcOEt} / \mathrm{MeOH}=19 / 1$ ) and preparative HPLC $(0.1 \%$ TFA-containing MeCN/0.1\% TFA-containing water $=1 / 1$ to $7 / 3)$ to give the title compound (104 mg, 22\%) as a pale yellow powder. ${ }^{1} \mathrm{H}$ NMR (DMSO- $\left.d_{6}\right) \delta 1.22$ $(3 \mathrm{H}, \mathrm{t}, J=7.5 \mathrm{~Hz}), 2.70(2 \mathrm{H}, \mathrm{q}, J=7.5 \mathrm{~Hz}), 3.98(3 \mathrm{H}, \mathrm{s}), 4.63(2 \mathrm{H}, \mathrm{s}), 4.77(2 \mathrm{H}, \mathrm{q}, J$ = 9.3 Hz), 7.51-7.63 (2 H, m), 7.64-7.74 (1 H, m), $7.82(1 \mathrm{H}, \mathrm{s}), 8.04-8.17(2 \mathrm{H}, \mathrm{m})$, 13.35 (1 H, br s).

\section{6-Ethyl-1-methyl-5-[(phenylcarbonyl)amino]-3-(2,2,2-trifluoroethoxy)-1H-pyrrolo [2,3-b]pyridine-2-carboxylic acid (26c)}

In the same manner as in the preparation of 26a, the title compound $(75.4 \mathrm{mg}$, $95 \%)$ was obtained as a white powder from $44(84.5 \mathrm{mg}, 0.188 \mathrm{mmol}) .{ }^{1} \mathrm{H} \mathrm{NMR}$ $\left(\mathrm{DMSO}-d_{6}\right) \delta 1.25(3 \mathrm{H}, \mathrm{t}, J=7.6 \mathrm{~Hz}), 2.88(2 \mathrm{H}, \mathrm{q}, J=7.6 \mathrm{~Hz}), 4.01(3 \mathrm{H}, \mathrm{s}), 4.78(2 \mathrm{H}$, q, $J=9.1 \mathrm{~Hz}), 7.47-7.73(3 \mathrm{H}, \mathrm{m}), 7.96(1 \mathrm{H}, \mathrm{s}), 7.98-8.09(2 \mathrm{H}, \mathrm{m}), 10.12(1 \mathrm{H}, \mathrm{s})$, $13.28(1 \mathrm{H}$, br s).

\section{Ethyl 2-chloro-4-ethylbenzoate (46)}

A mixture of 45 (1.00 g, $3.79 \mathrm{mmol})$, tributyl(vinyl)tin $(2.41 \mathrm{~g}, 7.59 \mathrm{mmol})$ and $\mathrm{Pd}\left(\mathrm{PPh}_{3}\right)_{4}(439 \mathrm{mg}, 0.38 \mathrm{mmol})$ in DMF $(15 \mathrm{~mL})$ was stirred at $100{ }^{\circ} \mathrm{C}$ for $1 \mathrm{~h}$. After cooling, the mixture was diluted with water $(150 \mathrm{~mL})$, and extracted twice with AcOEt. The extracts were combined, washed with brine, dried over $\mathrm{MgSO}_{4}$ and concentrated in vacuo. The residue was purified by silica gel column chromatography (hexane/AcOEt = $20 / 1)$ to give ethyl 2-chloro-4-ethenylbenzoate $(820 \mathrm{mg}, 100 \%)$ as colorless oil. A mixture of ethyl 2-chloro-4-ethenylbenzoate $(7.70 \mathrm{~g}, 36.55 \mathrm{mmol}), 5 \%$ barium hydroxide on palladium $(1.5 \mathrm{~g})$ in AcOEt $(150 \mathrm{~mL})$ was stirred at room temperature for $8 \mathrm{~h}$ under $\mathrm{H}_{2}$ atmosphere. The catalyst was filtered off, and the filtrate was concentrated in vacuo to give the title compound $(7.61 \mathrm{~g}, 98 \%)$ as pale yellow liquid. ${ }^{1} \mathrm{H}$ NMR $\left(\mathrm{CDCl}_{3}\right) \delta 1.24(3 \mathrm{H}, \mathrm{t}, J=7.5 \mathrm{~Hz}), 1.40(3 \mathrm{H}, \mathrm{t}, J=7.2 \mathrm{~Hz}), 2.65(2 \mathrm{H}, \mathrm{q}, J=7.5 \mathrm{~Hz})$, $4.38(2 \mathrm{H}, \mathrm{q}, J=7.2 \mathrm{~Hz}), 7.13(1 \mathrm{H}, \mathrm{dd}, J=8.1,1.2 \mathrm{~Hz}), 7.28(1 \mathrm{H}, \mathrm{d}, J=1.2 \mathrm{~Hz}), 7.76$ $(1 \mathrm{H}, \mathrm{d}, J=8.1 \mathrm{~Hz})$.

\section{Ethyl 2-chloro-4-ethyl-5-nitrobenzoate (29d)}

To a solution of $46(3.0 \mathrm{~g}, 14.1 \mathrm{mmol})$ in conc. $\mathrm{H}_{2} \mathrm{SO}_{4}(10 \mathrm{~mL})$ was added dropwise a solution of $\mathrm{NaNO}_{3}(1.20 \mathrm{~g}, 14.1 \mathrm{mmol})$ in conc. $\mathrm{H}_{2} \mathrm{SO}_{4}(10 \mathrm{~mL})$ at $0{ }^{\circ} \mathrm{C}$, and the mixture was stirred at $0{ }^{\circ} \mathrm{C}$ for $30 \mathrm{~min}$. The mixture was poured into water $(300 \mathrm{~mL})$ and extracted with AcOEt. The extract was washed with brine, dried over $\mathrm{MgSO}_{4}$ and 
concentrated in vacuo. The residue was purified by silica gel column chromatography (hexane/AcOEt $=20 / 1)$ to give the title compound $(2.56 \mathrm{~g}, 70 \%)$ as a pale yellow solid. ${ }^{1} \mathrm{H}$ NMR (DMSO- $\left.d_{6}\right) \delta 1.22(3 \mathrm{H}, \mathrm{t}, J=7.5 \mathrm{~Hz}), 1.34(3 \mathrm{H}, \mathrm{t}, J=7.1 \mathrm{~Hz}), 2.88(2 \mathrm{H}, \mathrm{q}$, $J=7.5 \mathrm{~Hz}), 4.36(2 \mathrm{H}, \mathrm{q}, J=7.1 \mathrm{~Hz}), 7.82(1 \mathrm{H}, \mathrm{s}), 8.38(1 \mathrm{H}, \mathrm{s})$.

\section{Ethyl 6-ethyl-3-hydroxy-1-methyl-5-nitro-1H-indole-2-carboxylate (27d)}

A mixture of $29 \mathrm{~d}(1.2 \mathrm{~g}, 4.66 \mathrm{mmol})$, ethyl sarcosinate hydrochloride $(2.86 \mathrm{~g}$, $18.6 \mathrm{mmol})$ and $\mathrm{Et}_{3} \mathrm{~N}(3.77 \mathrm{~g}, 37.3 \mathrm{mmol})$ in $\mathrm{EtOH}(20 \mathrm{~mL})$ was heated under reflux for $20 \mathrm{~h}$. After cooling, the mixture was partitioned between $\mathrm{HCl}$ aq. and AcOEt. The organic layer was separated, washed with brine, dried over $\mathrm{MgSO}_{4}$ and concentrated in vacuo. The residue was purified by silica gel column chromatography (hexane $/ \mathrm{AcOEt}=$ $3 / 1$ ) to give the title compound ( $557 \mathrm{mg}, 41 \%$ ) as a yellow solid. ${ }^{1} \mathrm{H}$ NMR (DMSO- $d_{6}$ ) $\delta$ $1.25(3 \mathrm{H}, \mathrm{t}, J=7.5 \mathrm{~Hz}), 1.33(3 \mathrm{H}, \mathrm{t}, J=7.1 \mathrm{~Hz}), 2.99(2 \mathrm{H}, \mathrm{q}, J=7.5 \mathrm{~Hz}), 3.90(3 \mathrm{H}$, s), $4.33(2 \mathrm{H}, \mathrm{q}, J=7.1 \mathrm{~Hz}), 7.53(1 \mathrm{H}, \mathrm{s}), 8.57(1 \mathrm{H}, \mathrm{s}), 9.92(1 \mathrm{H}, \mathrm{br} \mathrm{s})$.

\section{Ethyl 5-amino-6-ethyl-1-methyl-3-(2,2,2-trifluoroethoxy)-1H-indole-2-carboxylate} (47)

To a mixture of $\mathbf{2 7 d}(150 \mathrm{mg}, 0.51 \mathrm{mmol})$ and $\mathrm{Cs}_{2} \mathrm{CO}_{3}(200 \mathrm{mg}, 0.62 \mathrm{mmol})$ in DMF (3 mL) was added 2,2,2-trifluoroethyl trifluoromethanesulfonate (131 mg, 0.56 mmol), and the mixture was stirred at room temperature for $1 \mathrm{~h}$. The mixture was diluted with saturated $\mathrm{NaHCO}_{3}$ aq. and extracted with AcOEt. The extract was washed with brine, dried over $\mathrm{MgSO}_{4}$ and concentrated in vacuo. The residue was purified by silica gel column chromatography (hexane/AcOEt $=3 / 1$ ) to give the ethyl 6-ethyl-1-methyl-5-nitro-3-(2,2,2-trifluoroethoxy)-1H-indole-2-carboxylate (190 mg, $100 \%$ ) as a yellow solid. A mixture of obtained compound above (180 mg, $0.48 \mathrm{mmol})$ and $10 \% \mathrm{Pd}-\mathrm{C}(40 \mathrm{mg})$ in $\mathrm{EtOH}(10 \mathrm{~mL}) / \mathrm{THF}(4 \mathrm{~mL})$ was stirred at room temperature for $3 \mathrm{~h}$ under $\mathrm{H}_{2}$ atmosphere. The catalyst was removed by filtration and the filtrate was concentrated in vacuo to give the title compound $(160 \mathrm{mg}, 97 \%)$ as a pale brown solid. ${ }^{1} \mathrm{H}$ NMR $\left(\mathrm{DMSO}_{-} d_{6}\right) \delta 1.21(3 \mathrm{H}, \mathrm{t}, J=7.4 \mathrm{~Hz}), 1.33(3 \mathrm{H}, \mathrm{t}, J=7.1 \mathrm{~Hz}), 2.59(2 \mathrm{H}, \mathrm{q}, J$ $=7.4 \mathrm{~Hz}), 3.84(3 \mathrm{H}, \mathrm{s}), 4.31(2 \mathrm{H}, \mathrm{q}, J=7.1 \mathrm{~Hz}), 4.61(2 \mathrm{H}, \mathrm{q}, J=9.3 \mathrm{~Hz}), 4.67(2 \mathrm{H}, \mathrm{s})$, $6.77(1 \mathrm{H}, \mathrm{s}), 7.16(1 \mathrm{H}, \mathrm{s})$.

\section{Ethyl 6-ethyl-1-methyl-5-[(phenylcarbonyl)amino]-3-(2,2,2-trifluoroethoxy)-1H- indole-2-carboxylate (48)}

In the same manner as in the preparation of 44 , the title compound ( $89 \mathrm{mg}, 86 \%$ ) was obtained as a beige powder from $47(80 \mathrm{mg}, 0.23 \mathrm{mmol}) .{ }^{1} \mathrm{H}$ NMR (DMSO- $\left.d_{6}\right) \delta$ 
$1.20(3 \mathrm{H}, \mathrm{t}, J=7.4 \mathrm{~Hz}), 1.36(3 \mathrm{H}, \mathrm{t}, J=7.1 \mathrm{~Hz}), 2.74(2 \mathrm{H}, \mathrm{q}, J=7.4 \mathrm{~Hz}), 3.96(3 \mathrm{H}, \mathrm{s})$, $4.36(2 \mathrm{H}, \mathrm{q}, J=7.1 \mathrm{~Hz}), 4.74(2 \mathrm{H}, \mathrm{q}, J=9.0 \mathrm{~Hz}), 7.49-7.61(5 \mathrm{H}, \mathrm{m}), 8.01(2 \mathrm{H}, \mathrm{d}, J=$ $7.2 \mathrm{~Hz}), 9.97(1 \mathrm{H}, \mathrm{s})$.

\section{6-Ethyl-1-methyl-5-[(phenylcarbonyl)amino]-3-(2,2,2-trifluoroethoxy)-1H-indole -2-carboxylic acid (26d)}

In the same manner as in the preparation of 26a, the title compound ( $72 \mathrm{mg}, 95 \%$ ) was obtained as a white powder from $48(80 \mathrm{mg}, 0.18 \mathrm{mmol}) .{ }^{1} \mathrm{H}$ NMR (DMSO- $\left.d_{6}\right) \delta$ $1.20(3 \mathrm{H}, \mathrm{t}, J=7.5 \mathrm{~Hz}), 2.73(2 \mathrm{H}, \mathrm{q}, J=7.5 \mathrm{~Hz}), 3.96(3 \mathrm{H}, \mathrm{s}), 4.72(2 \mathrm{H}, \mathrm{q}, J=9.1$ $\mathrm{Hz}), 7.46-7.60(5 \mathrm{H}, \mathrm{m}), 8.01(2 \mathrm{H}, \mathrm{d}, J=6.9 \mathrm{~Hz}), 9.96(1 \mathrm{H}, \mathrm{s}), 13.20-13.40$ (1H, br).

\section{Ethyl 5-ethylpyridine-2-carboxylate (50)}

To a solution of $49(20.0 \mathrm{~g}, 86.9 \mathrm{mmol})$ in DMF $(100 \mathrm{~mL})$ were added tributyl(vinyl)tin $(28.1 \mathrm{~mL}, 95.6 \mathrm{mmol})$ and $\mathrm{Pd}\left(\mathrm{PPh}_{3}\right)_{4}(2.01 \mathrm{~g}, 1.74 \mathrm{mmol})$, and the mixture was stirred at $100{ }^{\circ} \mathrm{C}$ for $2 \mathrm{~h}$ under Ar atmosphere. The mixture was diluted with water $(200 \mathrm{~mL})$, and extracted with AcOEt $(400 \mathrm{~mL})$. The extracts were combined, washed with brine $(200 \mathrm{~mL})$, dried over $\mathrm{Na}_{2} \mathrm{SO}_{4}$ and concentrated in vacuo. The residue was purified by silica gel column chromatography (hexane/AcOEt $=49 / 1$ to $4 / 1$ ) to give ethyl 5-ethenylpyridine-2-carboxylate (16.5 g, quant.) as pale yellow oil. To a solution of obtained compound above $(7.71 \mathrm{~g}, 43.5 \mathrm{mmol})$ in EtOH $(77 \mathrm{~mL})$ was added $10 \%$ Pd-C (1.54 g) and the mixture was stirred at room temperature for $3 \mathrm{~h}$ under $\mathrm{H}_{2}$ atmosphere. The mixture was filtered through membrane filter, and the filtrate was concentrated in vacuo to give the title compound (7.92 g, quant.) as pale yellow oil. ${ }^{1} \mathrm{H}$ NMR $\left(\mathrm{DMSO}-d_{6}\right) \delta 1.22(3 \mathrm{H}, \mathrm{t}, J=7.6 \mathrm{~Hz}), 1.33(3 \mathrm{H}, \mathrm{t}, J=7.1 \mathrm{~Hz}), 2.71(2 \mathrm{H}, \mathrm{q}, J=$ $7.6 \mathrm{~Hz}), 4.33(2 \mathrm{H}, \mathrm{q}, J=7.1 \mathrm{~Hz}), 7.83(1 \mathrm{H}, \mathrm{dd}, J=8.0,2.2 \mathrm{~Hz}), 7.98(1 \mathrm{H}, \mathrm{d}, J=8.0$ $\mathrm{Hz}), 8.58(1 \mathrm{H}, \mathrm{d}, J=2.2 \mathrm{~Hz})$.

\section{Ethyl 5-ethyl-6-oxo-1,6-dihydropyridine-2-carboxylate (51)}

To a solution of 50 (1.28 g, $7.14 \mathrm{mmol})$ in $\mathrm{MeCN}(13 \mathrm{~mL})$ was added 3-chloroperoxybenzoic acid $(2.84 \mathrm{~g}, 10.7 \mathrm{mmol})$, and the mixture was stirred at room temperature for $20 \mathrm{~h}$. The mixture was concentrated to half volume, and diluted with AcOEt $(50 \mathrm{~mL})$. The solution was poured into saturated $\mathrm{NaHCO}_{3}$ solution $(100 \mathrm{~mL})$, and extracted with AcOEt $(200 \mathrm{~mL})$. The organic layer was washed with brine $(50 \mathrm{~mL})$, dried over $\mathrm{Na}_{2} \mathrm{SO}_{4}$ and concentrated in vacuo. The residue was purified by silica gel column chromatography (hexane/AcOEt $=9 / 1$ to AcOEt) to give ethyl 5-ethylpyridine-2-carboxylate 1-oxide $(1.15 \mathrm{~g}, 83 \%)$ as yellow oil. To a solution of 
obtained compound in DMF $(12 \mathrm{~mL})$ was added trifluoroacetic anhydride $(8.19 \mathrm{~mL}$, $58.9 \mathrm{mmol}$ ), and the mixture was stirred at room temperature for $12 \mathrm{~h}$ under $\mathrm{Ar}$ atmosphere. The mixture was concentrated in vacuo, and diluted with water $(50 \mathrm{~mL})$. The mixture was extracted with AcOEt $(100 \mathrm{~mL})$. The organic layer was washed with brine $(50 \mathrm{~mL})$, dried over $\mathrm{Na}_{2} \mathrm{SO}_{4}$ and concentrated in vacuo. The residue was purified by silica gel column chromatography (hexane/AcOEt $=19 / 1$ to $1 / 1$ ) to give the title compound (1.10 g, 96\%) as yellow oil. ${ }^{1} \mathrm{H}$ NMR (DMSO- $\left.d_{6}\right) \delta 1.11(3 \mathrm{H}, \mathrm{t}, J=7.5 \mathrm{~Hz})$, $1.30(3 \mathrm{H}, \mathrm{t}, J=7.1 \mathrm{~Hz}), 2.41-2.49(2 \mathrm{H}, \mathrm{m}), 4.29(2 \mathrm{H}, \mathrm{q}, J=7.1 \mathrm{~Hz}), 6.99(1 \mathrm{H}, \mathrm{d}, J=$ $7.0 \mathrm{~Hz}), 7.41(1 \mathrm{H}, \mathrm{d}, J=7.0 \mathrm{~Hz}), 11.53(1 \mathrm{H}, \mathrm{br} \mathrm{s})$.

\section{Ethyl 6-(benzyloxy)-3-bromo-5-ethylpyridine-2-carboxylate (29e)}

To a solution of $51(1.10 \mathrm{~g}, 5.63 \mathrm{mmol})$ in DMF $(11 \mathrm{~mL})$ was added $N$-bromosuccinimide $(1.30 \mathrm{~g}, 7.33 \mathrm{mmol})$, and the mixture was stirred at room temperature for $1 \mathrm{~h}$. The mixture was diluted with water $(50 \mathrm{~mL})$, and the resulting precipitate was collected by filtration to give ethyl 3-bromo-5-ethyl-6-oxo-1,6-dihydropyridine-2-carboxylate $(1.21 \mathrm{~g}, 79 \%)$ as a white solid. To a solution of obtained bromide $(17.1 \mathrm{~g}, 62.3 \mathrm{mmol})$ in toluene $(342 \mathrm{~mL})$ were added $\mathrm{Ag}_{2} \mathrm{CO}_{3}(29.2 \mathrm{~g}, 106 \mathrm{mmol})$ and benzyl bromide $(14.8 \mathrm{~mL}, 125 \mathrm{mmol})$, and the mixture was stirred at $40{ }^{\circ} \mathrm{C}$ for $2 \mathrm{~h}$. The insoluble material was filtered, and the filtrate was concentrated in vacuo. The residue was purified by silica gel column chromatography (hexane to hexane/AcOEt $=47 / 3)$ to give the title compound $(22.4 \mathrm{~g}$, 99\%) as yellow oil. ${ }^{1} \mathrm{H}$ NMR (DMSO- $\left.d_{6}\right) \delta 1.14(3 \mathrm{H}, \mathrm{t}, J=7.4 \mathrm{~Hz}), 1.34(3 \mathrm{H}, \mathrm{t}, J=7.0$ $\mathrm{Hz}), 2.60(2 \mathrm{H}, \mathrm{q}, J=7.4 \mathrm{~Hz}), 4.36(2 \mathrm{H}, \mathrm{q}, J=7.0 \mathrm{~Hz}), 5.35(2 \mathrm{H}, \mathrm{s}), 7.31-7.43(3 \mathrm{H}, \mathrm{m})$, 7.45-7.53 (2H, m), $7.92(1 \mathrm{H}, \mathrm{s})$.

\section{Ethyl 3-amino-6-(benzyloxy)-5-ethylpyridine-2-carboxylate (52)}

In the same manner as in the preparation of 43 , the title compound (17.8 g, 98\%) was obtained as yellow oil from 29e $(22.0 \mathrm{~g}, 60.4 \mathrm{mmol}) .{ }^{1} \mathrm{H}$ NMR (DMSO- $\left.d_{6}\right) \delta 1.12$ $(3 \mathrm{H}, \mathrm{t}, J=7.5 \mathrm{~Hz}), 1.33(3 \mathrm{H}, \mathrm{t}, J=7.1 \mathrm{~Hz}), 2.45-2.58(2 \mathrm{H}, \mathrm{m}), 4.27(2 \mathrm{H}, \mathrm{q}, J=7.1 \mathrm{~Hz})$, 5.26 (2H, s), $6.33(2 \mathrm{H}, \mathrm{s}), 7.08(1 \mathrm{H}, \mathrm{s}), 7.27-7.40(3 \mathrm{H}, \mathrm{m}), 7.48-7.57(2 \mathrm{H}, \mathrm{m})$.

\section{Ethyl 6-(benzyloxy)-3-[(2-ethoxy-2-oxoethyl)(methyl)amino]-5-ethylpyridine-2- carboxylate (28e)}

To a solution of $52(771 \mathrm{mg}, 2.57 \mathrm{mmol})$ in tert-butanol $(7.7 \mathrm{~mL})$ was added di-tert-butyl dicarbonate $(1.77 \mathrm{~mL}, 7.71 \mathrm{mmol})$, and the mixture was stirred at $90{ }^{\circ} \mathrm{C}$ for $18 \mathrm{~h}$. The mixture was concentrated in vacuo, and the residue was dissolved in DMF (10 
$\mathrm{mL})$. To the solution were added $\mathrm{Cs}_{2} \mathrm{CO}_{3}(2.93 \mathrm{~g}, 9.00 \mathrm{mmol})$ and iodomethane $(480 \mu \mathrm{L}$, $7.71 \mathrm{mmol}$ ), and the mixture was stirred at room temperature for $4 \mathrm{~h}$. The mixture was diluted with water $(50 \mathrm{~mL})$, and extracted with AcOEt $(100 \mathrm{~mL})$. The organic layer was washed with brine $(50 \mathrm{~mL})$, dried over $\mathrm{Na}_{2} \mathrm{SO}_{4}$ and concentrated in vacuo. To this residue was added $4 \mathrm{M} \mathrm{HCl} / \mathrm{AcOEt}(5.4 \mathrm{~mL})$, and the mixture was stirred at $0{ }^{\circ} \mathrm{C}$ for $2 \mathrm{~h}$. The mixture was diluted with saturated $\mathrm{NaHCO}_{3}$ aq. $(50 \mathrm{~mL})$ and extracted with AcOEt $(100 \mathrm{~mL})$. The organic layer was washed with brine $(50 \mathrm{~mL})$, dried over $\mathrm{Na}_{2} \mathrm{SO}_{4}$, and concentrated in vacuo. The residue was purified by column chromatography (hexane/AcOEt $=49 / 1$ to 47/3) to give ethyl 6-(benzyloxy)-5-ethyl-3-(methylamino)pyridine-2-carboxylate (705 mg, 87\%) as yellow oil. To a solution of the compound obtained above in DMF (14 mL) were added diisopropylethylamine $(2.35 \mathrm{~mL}, 13.5 \mathrm{mmol})$ and ethyl bromoacetate $(1.49 \mathrm{~mL}, 13.5$ mmol), and the mixture was stirred at $110{ }^{\circ} \mathrm{C}$ for $24 \mathrm{~h}$. The mixture was diluted with water $(50 \mathrm{~mL})$, and extracted with AcOEt $(100 \mathrm{~mL})$. The organic layer was washed with brine $(50 \mathrm{~mL})$, dried over $\mathrm{Na}_{2} \mathrm{SO}_{4}$, and concentrated in vacuo. The residue was purified by silica gel column chromatography (hexane to hexane/AcOEt $=4 / 1$ ) to give the title compound (711 mg, 79\%) as yellow oil. ${ }^{1} \mathrm{H}$ NMR (DMSO- $\left.d_{6}\right) \delta 1.09-1.21(6 \mathrm{H}, \mathrm{m}), 1.30$ $(3 \mathrm{H}, \mathrm{t}, J=7.1 \mathrm{~Hz}), 2.57(2 \mathrm{H}, \mathrm{q}, J=7.4 \mathrm{~Hz}), 2.81(3 \mathrm{H}, \mathrm{s}), 3.88(2 \mathrm{H}, \mathrm{s}), 4.07(2 \mathrm{H}, \mathrm{q}, J=$ $7.1 \mathrm{~Hz}), 4.28(2 \mathrm{H}, \mathrm{q}, J=7.1 \mathrm{~Hz}), 5.28(2 \mathrm{H}, \mathrm{s}), 7.26-7.42(3 \mathrm{H}, \mathrm{m}), 7.42-7.51(3 \mathrm{H}, \mathrm{m})$.

\section{Ethyl 5-(benzyloxy)-6-ethyl-3-hydroxy-1-methyl-1H-pyrrolo[3,2-b]pyridine-2- carboxylate (27e)}

To a solution of 28e (711 mg, $1.78 \mathrm{mmol})$ in $\mathrm{EtOH}(14 \mathrm{~mL})$ was added $20 \%$ solution of $\mathrm{NaOEt}$ in $\mathrm{EtOH}(1.42 \mathrm{~mL})$, and the mixture was stirred at room temperature for $1 \mathrm{~h}$. The mixture was concentrated in vacuo, acidified with $1 \mathrm{M} \mathrm{HCl}$ aq., and extracted with AcOEt $(100 \mathrm{~mL})$. The organic layer was washed with brine $(50 \mathrm{~mL})$, dried over $\mathrm{Na}_{2} \mathrm{SO}_{4}$ and concentrated in vacuo. The precipitate was collected by filtration, and washed with IPE to give the title compound ( $485 \mathrm{mg}, 77 \%$ ) as a pale orange powder. ${ }^{1} \mathrm{H}$ NMR $\left(\mathrm{DMSO}-d_{6}\right) \delta 1.22(3 \mathrm{H}, \mathrm{t}, J=7.4 \mathrm{~Hz}), 1.34(3 \mathrm{H}, \mathrm{t}, J=7.1 \mathrm{~Hz}), 2.69(2 \mathrm{H}, \mathrm{q}, J$ $=7.4 \mathrm{~Hz}), 3.84(3 \mathrm{H}, \mathrm{s}), 4.35(2 \mathrm{H}, \mathrm{q}, J=7.1 \mathrm{~Hz}), 5.44(2 \mathrm{H}, \mathrm{s}), 7.27-7.44(3 \mathrm{H}, \mathrm{m})$, 7.46-7.56 (2H, m), $7.78(1 \mathrm{H}, \mathrm{s}), 8.84(1 \mathrm{H}, \mathrm{s})$.

\section{Ethyl 6-ethyl-1-methyl-3-(2,2,2-trifluoroethoxy)-5-\{[(trifluoromethyl)sulfonyl]oxy\}}

\section{-1H-pyrrolo[3,2-b]pyridine-2-carboxylate (53)}

To a solution of 27e $(485 \mathrm{mg}, 1.37 \mathrm{mmol})$ in DMF $(4.9 \mathrm{~mL})$ were added $\mathrm{Cs}_{2} \mathrm{CO}_{3}$ (534 mg, $1.64 \mathrm{mmol})$ and 2,2,2-trifluoroethyl trifluoromethanesulfonate $(217 \mu \mathrm{L}, 1.51$ 
mmol), and the mixture was stirred at room temperature for $1 \mathrm{~h}$. The mixture was diluted with water $(20 \mathrm{~mL})$, and the precipitate was collected by filtration, washed with water and IPE to give ethyl 5-(benzyloxy)-6-ethyl-1-methyl-3-(2,2,2-trifluoroethoxy)-1H-pyrrolo[3,2-b]pyridine-2carboxylate $(580 \mathrm{mg}, 97 \%$ ) as a pale orange powder. To a solution of obtained powder (428 mg, $0.981 \mathrm{mmol})$ in EtOH $(0.87 \mathrm{~mL}) /$ THF $(0.43 \mathrm{~mL})$ was added 10\% Pd-C (128 $\mathrm{mg}$ ), and the mixture was stirred at room temperature for $1 \mathrm{~h}$ under $\mathrm{H}_{2}$ atmosphere. The mixture was filtered through membrane filter, and the filtrate was concentrated in vacuo. The resulting solid was collected by filtration to give ethyl 6-ethyl-1-methyl-5-oxo-3-(2,2,2-trifluoroethoxy)-4,5-dihydro-1 $H$-pyrrolo[3,2-b]pyridin e -2-carboxylate (330 mg, 97\%) as a white solid. To a solution of obtained solid (330 $\mathrm{mg}, 0.953 \mathrm{mmol})$ in pyridine $(9.9 \mathrm{~mL})$ was added $\mathrm{Tf}_{2} \mathrm{O}(384 \mu \mathrm{L}, 2.28 \mathrm{mmol})$ at $0{ }^{\circ} \mathrm{C}$, and the mixture was stirred at $60{ }^{\circ} \mathrm{C}$ for $16 \mathrm{~h}$ under $\mathrm{N}_{2}$ atmosphere. The mixture was concentrated in vacuo, the residue was diluted with saturated $\mathrm{NaHCO}_{3}$ aq. ( $50 \mathrm{~mL}$ ), and extracted with AcOEt $(100 \mathrm{~mL})$. The organic layer was washed with brine $(50 \mathrm{~mL})$, dried over $\mathrm{Na}_{2} \mathrm{SO}_{4}$ and concentrated in vacuo. The resulting solid was collected by filtration, and washed with hexane to give the title compound (418 $\mathrm{mg}, 92 \%)$ as a pale yellow powder. ${ }^{1} \mathrm{H}$ NMR (DMSO- $\left.d_{6}\right) \delta 1.24-1.39(6 \mathrm{H}, \mathrm{m}), 2.79(2 \mathrm{H}, \mathrm{q}, J=7.6 \mathrm{~Hz})$, $3.99(3 \mathrm{H}, \mathrm{s}), 4.36(2 \mathrm{H}, \mathrm{q}, J=7.2 \mathrm{~Hz}), 5.05(2 \mathrm{H}, \mathrm{q}, J=8.9 \mathrm{~Hz}), 8.35(1 \mathrm{H}, \mathrm{s})$.

\section{Ethyl 5-amino-6-ethyl-1-methyl-3-(2,2,2-trifluoroethoxy)-1H-pyrrolo[3,2-b] pyridine-2-carboxylate (54)}

In the same manner as in the preparation of 43 , the title compound (141 $\mathrm{g}, 90 \%)$ was obtained as a white powder from $53(218 \mathrm{mg}, 0.456 \mathrm{mmol}) .{ }^{1} \mathrm{H}$ NMR (DMSO- $\left.d_{6}\right) \delta$ $1.20(3 \mathrm{H}, \mathrm{t}, J=7.5 \mathrm{~Hz}), 1.29(3 \mathrm{H}, \mathrm{t}, J=7.1 \mathrm{~Hz}), 2.51-2.61(2 \mathrm{H}, \mathrm{m}), 3.83(3 \mathrm{H}, \mathrm{s}), 4.26$ $(2 \mathrm{H}, \mathrm{q}, J=7.1 \mathrm{~Hz}), 5.10(2 \mathrm{H}, \mathrm{q}, J=9.1 \mathrm{~Hz}), 5.75(2 \mathrm{H}, \mathrm{s}), 7.55(1 \mathrm{H}, \mathrm{s})$.

\section{6-Ethyl-1-methyl-5-[(phenylcarbonyl)amino]-3-(2,2,2-trifluoroethoxy)-1H-pyrrolo [3,2-b]pyridine-2-carboxylic acid (26e)}

To a solution of $54(141 \mathrm{mg}, 0.408 \mathrm{mmol})$ in THF $(1.4 \mathrm{~mL})$ were added pyridine $(85.8 \mu \mathrm{L}, 1.06 \mathrm{mmol})$ and benzoyl chloride $(104 \mu \mathrm{L}, 0.898 \mathrm{mmol})$, and the mixture was stirred at $50{ }^{\circ} \mathrm{C}$ for $2 \mathrm{~h}$. The mixture was diluted with water $(30 \mathrm{~mL})$ and extracted with AcOEt $(50 \mathrm{~mL})$. The organic layer was washed with brine $(30 \mathrm{~mL})$, dried over $\mathrm{Na}_{2} \mathrm{SO}_{4}$ and concentrated in vacuo. To a solution of the residue in EtOH $(3.7 \mathrm{~mL})$ was added aqueous $8 \mathrm{M} \mathrm{NaOH}$ aq. $(0.366 \mathrm{~mL})$, and the mixture was stirred at $50{ }^{\circ} \mathrm{C}$ for $1 \mathrm{~h}$. The mixture was concentrated in vacuo, the precipitate was diluted with water $(20 \mathrm{~mL})$ and 
acidified with aqueous $1 \mathrm{M} \mathrm{HCl}$ aq.. The resulting precipitate was collected by filtration, and washed with water to give the title compound $(152 \mathrm{mg}, 88 \%)$ as a white solid. ${ }^{1} \mathrm{H}$ NMR (DMSO- $\left.d_{6}\right) \delta 1.23(3 \mathrm{H}, \mathrm{t}, J=7.5 \mathrm{~Hz}), 2.71(2 \mathrm{H}, \mathrm{q}, J=7.5 \mathrm{~Hz}), 3.97(3 \mathrm{H}, \mathrm{s}), 5.10$ $(2 \mathrm{H}, \mathrm{q}, J=9.1 \mathrm{~Hz}), 7.49-7.65(3 \mathrm{H}, \mathrm{m}), 7.97-8.06(3 \mathrm{H}, \mathrm{m}), 10.56(1 \mathrm{H}, \mathrm{s}), 13.17(1 \mathrm{H}, \mathrm{br}$ s).

\section{Ethyl 5-ethyl-3-hydroxypyrazine-2-carboxylate (56)}

To a suspension of $55(6.40 \mathrm{~g}, 39.7 \mathrm{mmol})$ in EtOH $(60 \mathrm{~mL})$ was added diisopropylethylamine $(14 \mathrm{~mL}, 80.4 \mathrm{mmol})$, and the mixture was stirred at room temperature for $10 \mathrm{~min}$. To this solution was added dropwise diethyl ketomalonate (6 $\mathrm{mL}, 39.3 \mathrm{mmol}$ ) at $0{ }^{\circ} \mathrm{C}$, and the mixture was stirred at room temperature for $1.5 \mathrm{~h}$ and with heating under reflux for $20 \mathrm{~h}$. The reaction mixture was concentrated in vacuo, and the residue was dissolved in a small amount of EtOH. The solution was passed through silica gel (hexane/AcOEt $=1 / 1$ to AcOEt). The eluate was concentrated in vacuo, and the residue was purified by silica gel column chromatography (hexane/AcOEt $=2 / 1$ to AcOEt) to give the title compound $(1.94 \mathrm{~g}, 25 \%)$ as a pale yellow powder. ${ }^{1} \mathrm{H}$ NMR $\left(\mathrm{DMSO}_{-} d_{6}\right) \delta 1.19(3 \mathrm{H}, \mathrm{t}, J=7.6 \mathrm{~Hz}), 1.27(3 \mathrm{H}, \mathrm{t}, J=7.2 \mathrm{~Hz}), 2.53-2.62(2 \mathrm{H}, \mathrm{m})$, $4.26(2 \mathrm{H}, \mathrm{q}, J=7.2 \mathrm{~Hz}), 7.42$ (1 H, br s), 12.68 (1 H, br s).

\section{Ethyl 3-(benzyloxy)-6-bromo-5-ethylpyrazine-2-carboxylate (57)}

To a solution of 56 (3.75 g, $19.1 \mathrm{mmol})$ in DMF (40 $\mathrm{mL})$ was added $\mathrm{N}$-bromosuccinimide $(3.43 \mathrm{~g}, 19.3 \mathrm{mmol})$ at $0{ }^{\circ} \mathrm{C}$. The mixture was diluted with water $(80 \mathrm{~mL})$, and the precipitate was collected by filtration washed with water to give ethyl 6-bromo-5-ethyl-3-hydroxypyrazine-2-carboxylate. The filtrate was extracted with $\mathrm{Et}_{2} \mathrm{O} / \mathrm{AcOEt}=1 / 1$ solution, the extracts were washed with brine, dried over $\mathrm{MgSO}_{4}$ and concentrated in vacuo. The residue was purified by silica gel column chromatography (hexane/AcOEt $=99 / 1$ to 4/1) to give ethyl 6-bromo-5-ethyl-3-hydroxypyrazine-2-carboxylate. To a solution of the obtained compound above $(750 \mathrm{mg}, 2.73 \mathrm{mmol})$ in toluene $(10 \mathrm{~mL})$ were added $\mathrm{Ag}_{2} \mathrm{CO}_{3}(1.05 \mathrm{~g}$, $3.81 \mathrm{mmol})$ and benzyl bromide $(390 \mu \mathrm{L}, 3.28 \mathrm{mmol})$ at $0{ }^{\circ} \mathrm{C}$, the mixture was stirred at room temperature for $3 \mathrm{~h}$. The insoluble material was removed by filtration through celite pad, and the filtrate was concentrated in vacuo. The residue was purified by silica gel column chromatography (hexane/AcOEt $=99 / 1$ to $4 / 1$ ) to give the title compound (908 mg, 91\%) as colorless oil. ${ }^{1} \mathrm{H}$ NMR (DMSO- $\left.d_{6}\right) \delta 1.25(3 \mathrm{H}, \mathrm{t}, J=7.5 \mathrm{~Hz}), 1.29$ (3 $\mathrm{H}, \mathrm{t}, J=7.1 \mathrm{~Hz}), 2.89(2 \mathrm{H}, \mathrm{q}, J=7.5 \mathrm{~Hz}), 4.33(2 \mathrm{H}, \mathrm{q}, J=7.1 \mathrm{~Hz}), 5.50(2 \mathrm{H}, \mathrm{s})$, 7.28-7.44 (3 H, m), 7.44-7.56 (2 H, m). 
Ethyl 3-(benzyloxy)-5-ethyl-6-[(phenylcarbonyl)amino]pyrazine-2-carboxylate (58)

To a mixture of 57 (906 mg, $2.48 \mathrm{mmol})$, benzophenoneimine (624 $\mu \mathrm{L}, 3.72$ $\mathrm{mmol}), \mathrm{Cs}_{2} \mathrm{CO}_{3}(1.62 \mathrm{~g}, 4.97 \mathrm{mmol})$ in toluene $(13 \mathrm{~mL})$ were added xantphos $(294 \mathrm{mg}$, $0.508 \mathrm{mmol})$ and $\mathrm{Pd}_{2}(\mathrm{dba})_{3}(228 \mathrm{mg}, 0.249 \mathrm{mmol})$, and the mixture was stirred at $100{ }^{\circ} \mathrm{C}$ for $14 \mathrm{~h}$. Benzophenoneimine (416 $\left.\mu \mathrm{L}, 2.48 \mathrm{mmol}\right), \mathrm{Pd}_{2}(\mathrm{dba})_{3}(120 \mathrm{mg}, 0.131$ $\mathrm{mmol})$ and xantphos (148 $\mathrm{mg}, 0.256 \mathrm{mmol})$ were further added, the mixture was stirred at $100{ }^{\circ} \mathrm{C}$ for $3.5 \mathrm{~h}$. The mixture was filtered through celite pad using AcOEt, and the filtrate was washed with water and brine. The organic layer was dried over $\mathrm{MgSO}_{4}$, and concentrated in vacuo. The residue was dissolved in THF $(10 \mathrm{~mL}) / \mathrm{EtOH}(2 \mathrm{~mL})$, and $2 \mathrm{M} \mathrm{HCl}$ aq. $(3 \mathrm{~mL})$ was added. After stirring for $3 \mathrm{~h}$, the mixture was quenched with aqueous $\mathrm{NaHCO}_{3}$ solution, and extracted with AcOEt. The extracts were washed with brine, dried over $\mathrm{MgSO}_{4}$ and concentrated in vacuo. The residue was purified by silica gel column chromatography (hexane/AcOEt $=19 / 1$ to $1 / 2$ ) to give ethyl 6-amino-3-(benzyloxy)-5-ethylpyrazine-2-carboxylate (441 $\mathrm{mg}, 59 \%$ ) as a brown powder. To a solution of obtained product $(250 \mathrm{mg}, 0.828 \mathrm{mmol})$ in THF $(3 \mathrm{~mL})$ were added pyridine $(100 \mu \mathrm{L}, 1.24 \mathrm{mmol})$ and benzoyl chloride $(106 \mu \mathrm{L}, 0.913 \mathrm{mmol})$ at $0{ }^{\circ} \mathrm{C}$, and the mixture was stirred at $0{ }^{\circ} \mathrm{C}$ for $2.5 \mathrm{~h}$. Benzoyl chloride $(53 \mu \mathrm{L}, 0.457 \mathrm{mmol})$ was added, and the mixture was stirred at $0{ }^{\circ} \mathrm{C}$ for $1 \mathrm{~h}$. Further benzoyl chloride $(53 \mu \mathrm{L}$, $0.457 \mathrm{mmol})$ and pyridine $(55 \mu \mathrm{L}, 0.680 \mathrm{mmol})$ were added, the mixture was stirred at $0{ }^{\circ} \mathrm{C}$ for $1 \mathrm{~h}$. The mixture was quenched with aqueous $\mathrm{NaHCO}_{3}$ solution, and the mixture was extracted with AcOEt. The organic layer was dried over $\mathrm{MgSO}_{4}$, and concentrated in vacuo. The residue was purified by silica gel column chromatography (hexane/AcOEt $=19 / 1$ to $1 / 1)$ to give the title compound (312 $\mathrm{mg}, 93 \%$ ) as an orange oil. ${ }^{1} \mathrm{H}$ NMR (DMSO- $\left.d_{6}\right) \delta 1.22(3 \mathrm{H}, \mathrm{t}, J=7.5 \mathrm{~Hz}), 1.28(3 \mathrm{H}, \mathrm{t}, J=7.1 \mathrm{~Hz}), 2.73(2 \mathrm{H}$, q, $J=7.5 \mathrm{~Hz}), 4.33(2 \mathrm{H}, \mathrm{q}, J=7.1 \mathrm{~Hz}), 5.55(2 \mathrm{H}, \mathrm{s}), 7.28-7.47(3 \mathrm{H}, \mathrm{m}), 7.47-7.71$ (5 $\mathrm{H}, \mathrm{m}), 7.95-8.09$ (2 H, m), $10.76(1 \mathrm{H}, \mathrm{s})$.

\section{Ethyl 5-ethyl-6-[(phenylcarbonyl)amino]-3-\{[(trifluoromethyl)sulfonyl]oxy\} pyrazine-2-carboxylate (29f)}

To a solution of $58(310 \mathrm{mg}, 0.765 \mathrm{mmol})$ in EtOH $(5 \mathrm{~mL})$ was added $10 \% \mathrm{Pd}-\mathrm{C}$ ( $32.7 \mathrm{mg}$ ), and the mixture was stirred at room temperature for $3 \mathrm{~h}$ under $\mathrm{H}_{2}$ atmosphere. The catalyst was removed by filtration through celite pad, and the filtrate was concentrated in vacuo. The residue was purified by silica gel column chromatography (hexane/AcOEt $=9 / 1$ to $1 / 4)$ to give ethyl 5-ethyl-3-hydroxy-6-[(phenylcarbonyl)amino]pyrazine-2-carboxylate (185 $\mathrm{mg}, 77 \%)$ as a pale yellow powder. To a solution of the compound obtained above (183 mg, 0.580 
mmol) in pyridine $(2 \mathrm{~mL})$ was added dropwise $\mathrm{Tf}_{2} \mathrm{O}(147 \mu \mathrm{L}, 0.871 \mathrm{mmol})$ at $0{ }^{\circ} \mathrm{C}$, and the mixture was stirred at $0{ }^{\circ} \mathrm{C}$ for $1 \mathrm{~h}$. Further $\mathrm{Tf}_{2} \mathrm{O}(30 \mu \mathrm{L}, 0.178 \mathrm{mmol})$ was added, and the mixture was stirred at $0{ }^{\circ} \mathrm{C}$ for $1 \mathrm{~h}$. The mixture was diluted with water $(15 \mathrm{~mL})$, and the mixture was extracted three times with AcOEt $(15 \mathrm{~mL})$. The extracts were combined, washed with water $(20 \mathrm{~mL})$ and brine $(10 \mathrm{~mL})$, dried over $\mathrm{MgSO}_{4}$ and concentrated in vacuo. The residue was purified by silica gel column chromatography (hexane/AcOEt $=49 / 1$ to $1 / 1$ ) to give the title compound (244 $\mathrm{mg}, 94 \%$ ) as yellow oil. ${ }^{1} \mathrm{H}$ NMR (DMSO- $\left.d_{6}\right) \delta 1.21(3 \mathrm{H}, \mathrm{t}, J=7.3 \mathrm{~Hz}), 1.34(3 \mathrm{H}, \mathrm{t}, J=7.1 \mathrm{~Hz}), 2.83(2 \mathrm{H}, \mathrm{q}$, $J=7.3 \mathrm{~Hz}), 4.43$ (2 H, q, $J=7.1 \mathrm{~Hz}), 7.49-7.74$ (3 H, m), 7.99-8.10 (2 H, m), 11.42 (1 $\mathrm{H}, \mathrm{s})$.

\section{Ethyl 3-ethyl-7-hydroxy-5-methyl-2-[(phenylcarbonyl)amino]-5H-pyrrolo[2,3-b] pyrazine-6-carboxylate (27f)}

In the same manner as in the preparation of $\mathbf{2 7 b}$, the title compound (159 $\mathrm{mg}$, $80 \%$ ) was obtained as a pale yellow powder from $29 \mathrm{f}(242 \mathrm{mg}, 0.541 \mathrm{mmol}) .{ }^{1} \mathrm{H}$ NMR $\left(\mathrm{DMSO}-d_{6}\right) \delta 1.28(3 \mathrm{H}, \mathrm{t}, J=7.6 \mathrm{~Hz}), 1.35(3 \mathrm{H}, \mathrm{t}, J=7.2 \mathrm{~Hz}), 2.88(2 \mathrm{H}, \mathrm{q}, J=7.6$ $\mathrm{Hz}), 3.95(3 \mathrm{H}, \mathrm{s}), 4.37$ (2 H, q, $J=7.2 \mathrm{~Hz}), 7.45-7.72$ (3 H, m), 7.94-8.12 (2 H, m), $9.91(1 \mathrm{H}$, br s), $10.72(1 \mathrm{H}, \mathrm{s})$.

\section{3-Ethyl-5-methyl-2-[(phenylcarbonyl)amino]-7-(2,2,2-trifluoroethoxy)-5H-pyrrolo [2,3-b]pyrazine-6-carboxylic acid (26f)}

To a solution of $27 \mathbf{f}(59.2 \mathrm{mg}, 0.161 \mathrm{mmol})$ in DMF were added $\mathrm{Cs}_{2} \mathrm{CO}_{3}(72.0 \mathrm{mg}$, $0.220 \mathrm{mmol})$ and 2,2,2-trifluoroethyl trifluoromethanesulfonate $(28 \mu \mathrm{L}, 0.166 \mathrm{mmol})$ at $0{ }^{\circ} \mathrm{C}$, and the mixture was stirred at $0{ }^{\circ} \mathrm{C}$ for $2 \mathrm{~h}$. The mixture was diluted with water, and the precipitate was collected by filtration. The collection was dissolved in hexane/AcOEt, and purified by silica gel column chromatography (hexane/AcOEt = $49 / 1$ to 2/1) to give ethyl 3-ethyl-5-methyl-2-[(phenylcarbonyl)amino]-7-(2,2,2-trifluoroethoxy)-5H-pyrrolo[2,3b]pyrazine-6-carboxylate $(53.2 \mathrm{mg}, 74 \%)$ as a pale yellow powder. To a solution of obtained compound above $(107 \mathrm{mg}, 0.238 \mathrm{mmol})$ in THF $(1 \mathrm{~mL}) / \mathrm{EtOH}(2 \mathrm{~mL})$ was added $1 \mathrm{M} \mathrm{NaOH}$ aq. $(0.5 \mathrm{~mL})$, and the mixture was stirred at room temperature for overnight. The mixture was acidified with $1 \mathrm{~N} \mathrm{HCl}$ aq., and diluted with water. The precipitate was collected by filtration using water to give the title compound ( $99.6 \mathrm{mg}$, 99\%) as a pale yellow powder. ${ }^{1} \mathrm{H}$ NMR (DMSO- $\left.d_{6}\right) \delta 1.29(3 \mathrm{H}, \mathrm{t}, J=7.4 \mathrm{~Hz}), 2.89$ (2 $\mathrm{H}, \mathrm{q}, J=7.4 \mathrm{~Hz}), 4.01(3 \mathrm{H}, \mathrm{s}), 5.10(2 \mathrm{H}, \mathrm{q}, J=8.9 \mathrm{~Hz}), 7.45-7.72(3 \mathrm{H}, \mathrm{m}), 7.96-8.10$ (2 H, m), $10.82(1 \mathrm{H}, \mathrm{s}), 13.47$ (1 H, br s). 


\section{2-Ethyl- $N$-[1-(hydroxyacetyl)piperidin-4-yl]-7-methyl-4-oxo-5-(2,2,2-trifluoro- ethoxy)-4,7-dihydro-3H-pyrrolo[2,3-d]pyrimidine-6-carboxamide (25a)}

To a mixture of 26a (1.0 g, $3.1 \mathrm{mmol})$, 2-(4-aminopiperidin-1-yl)-2-oxoethanol hydrochloride (732 mg, $3.7 \mathrm{mmol})$ and HOBt (635 mg, $4.7 \mathrm{mmol})$ in DMF (15 mL) were added $\mathrm{EDC}(900 \mathrm{mg}, 4.7 \mathrm{mmol})$ and $\mathrm{Et}_{3} \mathrm{~N}(1.2 \mathrm{~mL}, 8.5 \mathrm{mmol})$ at $0{ }^{\circ} \mathrm{C}$, and the mixture was stirred at room temperature for $4.5 \mathrm{~h}$. The reaction mixture was diluted with saturated $\mathrm{NaHCO}_{3}$ aq., and the precipitated solid was collected by filtration. The solid was washed with water, and dried in vacuo to give the title compound (1.1 g, 79\%) as a white powder. ${ }^{1} \mathrm{H}$ NMR $\left(\mathrm{DMSO}-d_{6}\right) \delta 1.13-1.52(5 \mathrm{H}, \mathrm{m}), 1.76-1.98(2 \mathrm{H}, \mathrm{m}), 2.63$ $(2 \mathrm{H}, \mathrm{q}, J=7.5 \mathrm{~Hz}), 2.75-2.95(1 \mathrm{H}, \mathrm{m}), 3.00-3.19(1 \mathrm{H}, \mathrm{m}), 3.61-3.75(1 \mathrm{H}, \mathrm{m}), 3.83$ $(3 \mathrm{H}, \mathrm{s}), 3.93-4.17(3 \mathrm{H}, \mathrm{m}), 4.17-4.34(1 \mathrm{H}, \mathrm{m}), 4.53(1 \mathrm{H}, \mathrm{t}, J=5.5 \mathrm{~Hz}), 5.20(2 \mathrm{H}, \mathrm{q}, J=$ $9.1 \mathrm{~Hz}), 7.43(1 \mathrm{H}, \mathrm{d}, J=7.7 \mathrm{~Hz}), 12.10(1 \mathrm{H}, \mathrm{s})$.

The following compounds 25b-f were prepared in a same manner similar to that described for $\mathbf{2 5 a}$.

\section{6-Ethyl- $N$-[1-(hydroxyacetyl)piperidin-4-yl]-1-methyl-5-(2-oxo-2-phenylethyl)-3-} (2,2,2-trifluoroethoxy)-1H-pyrrolo[2,3-b]pyridine-2-carboxamide (25b)

Yield $47 \%$, white crystals. mp. $150{ }^{\circ} \mathrm{C}$ (recrystallized from hexane/AcOEt) ${ }^{1} \mathrm{H}$ NMR (DMSO- $\left.d_{6}\right) \delta 1.22(3 \mathrm{H}, \mathrm{t}, J=7.4 \mathrm{~Hz}), 1.28-1.58(2 \mathrm{H}, \mathrm{m}), 1.82-2.02(2 \mathrm{H}, \mathrm{m}), 2.70$ $(2 \mathrm{H}, \mathrm{q}, J=7.2 \mathrm{~Hz}), 2.78-2.94(1 \mathrm{H}, \mathrm{m}), 3.02-3.21(1 \mathrm{H}, \mathrm{m}), 3.60-3.78(1 \mathrm{H}, \mathrm{m}), 3.93(3 \mathrm{H}$, s), 4.00-4.19 (3H, m), 4.20-4.36 (1H, m), $4.53(1 \mathrm{H}, \mathrm{t}, J=5.4 \mathrm{~Hz}), 4.63(2 \mathrm{H}, \mathrm{s}), 4.91(2 \mathrm{H}$, q, $J=8.9 \mathrm{~Hz}), 7.52-7.64(2 \mathrm{H}, \mathrm{m}), 7.64-7.74(1 \mathrm{H}, \mathrm{m}), 7.79(1 \mathrm{H}, \mathrm{d}, J=7.7 \mathrm{~Hz}), 8.03(1 \mathrm{H}$, s), $8.11(2 \mathrm{H}, \mathrm{d}, J=7.4 \mathrm{~Hz})$. Anal. Calcd for $\mathrm{C}_{28} \mathrm{H}_{31} \mathrm{~N}_{4} \mathrm{O}_{5} \mathrm{~F}_{3}: \mathrm{C}, 59.99 ; \mathrm{H}, 5.57$; N, 9.99 . Found: C, 59.75; H, 5.51; N, 9.81. LC-MS: $\mathrm{m} / \mathrm{z}=561\left(\mathrm{MH}^{+}\right)$.

\section{6-Ethyl- $N$-[1-(hydroxyacetyl)piperidin-4-yl]-1-methyl-5-[(phenylcarbonyl)amino]} -3-(2,2,2-trifluoroethoxy)-1H-pyrrolo[2,3-b]pyridine-2-carboxamide (25c)

Yield 53\%, white crystals. mp. $200{ }^{\circ} \mathrm{C}$ (recrystallized from hexane/AcOEt). ${ }^{1} \mathrm{H}$ NMR $\left(\mathrm{DMSO}-d_{6}\right) \delta 1.24(3 \mathrm{H}, \mathrm{t}, J=7.5 \mathrm{~Hz}), 1.32-1.55(2 \mathrm{H}, \mathrm{m}), 1.84-1.99(2 \mathrm{H}, \mathrm{m})$, 2.79-2.92 (1H, m), $2.86(2 \mathrm{H}, \mathrm{q}, J=7.5 \mathrm{~Hz}), 3.02-3.19(1 \mathrm{H}, \mathrm{m}), 3.63-3.78(1 \mathrm{H}, \mathrm{m}), 3.94$ $(3 \mathrm{H}, \mathrm{s}), 4.00-4.18(1 \mathrm{H}, \mathrm{m}), 4.10(2 \mathrm{H}, \mathrm{t}, J=5.7 \mathrm{~Hz}), 4.21-4.37(1 \mathrm{H}, \mathrm{m}), 4.53(1 \mathrm{H}, \mathrm{t}, J=$ $5.5 \mathrm{~Hz}), 4.94(2 \mathrm{H}, \mathrm{q}, J=8.8 \mathrm{~Hz}), 7.46-7.71(3 \mathrm{H}, \mathrm{m}), 7.86(1 \mathrm{H}, \mathrm{d}, J=7.6 \mathrm{~Hz}), 8.03(2 \mathrm{H}$, d, $J=6.8 \mathrm{~Hz}), 8.13(1 \mathrm{H}, \mathrm{s}), 10.11(1 \mathrm{H}, \mathrm{s})$. Anal. Calcd for $\mathrm{C}_{27} \mathrm{H}_{30} \mathrm{~N}_{5} \mathrm{O}_{5} \mathrm{~F}_{3}: \mathrm{C}, 57.75$; H,5.38; N,12.47. Found: C,58.03; H,5.47; N,12.44. LC-MS: $\mathrm{m} / \mathrm{z}=562\left(\mathrm{MH}^{+}\right)$. 
6-Ethyl- $N$-[1-(hydroxyacetyl)piperidin-4-yl]-1-methyl-5-[(phenylcarbonyl)amino] -3-(2,2,2-trifluoroethoxy)-1H-indole-2-carboxamide (25d)

Yield $82 \%$, white crystals. mp. $227{ }^{\circ} \mathrm{C}$ (recrystallized from hexane/AcOEt). ${ }^{1} \mathrm{H}$ NMR (DMSO- $\left.d_{6}\right) \delta 1.20(3 \mathrm{H}, \mathrm{t}, J=7.5 \mathrm{~Hz}), 1.30-1.50(2 \mathrm{H}, \mathrm{m}), 1.91(2 \mathrm{H}, \mathrm{d}, J=9.9 \mathrm{~Hz})$, $2.72(2 \mathrm{H}, \mathrm{q}, J=7.5 \mathrm{~Hz}), 2.82(1 \mathrm{H}, \mathrm{t}, J=11.9 \mathrm{~Hz}), 3.10(1 \mathrm{H}, \mathrm{t}, J=11.9 \mathrm{~Hz}), 3.71(1 \mathrm{H}, \mathrm{d}$, $J=12.9 \mathrm{~Hz}), 3.89(3 \mathrm{H}, \mathrm{s}), 4.04-4.12(3 \mathrm{H}, \mathrm{m}), 4.30(1 \mathrm{H}, \mathrm{d}, J=13.8 \mathrm{~Hz}), 4.54(1 \mathrm{H}, \mathrm{t}, J=$ $5.4 \mathrm{~Hz}), 4.85(2 \mathrm{H}, \mathrm{q}, J=8.9 \mathrm{~Hz}), 7.44(1 \mathrm{H}, \mathrm{s}), 7.51-7.62(4 \mathrm{H}, \mathrm{m}), 7.84(1 \mathrm{H}, \mathrm{d}, J=7.5$ $\mathrm{Hz}), 8.01(2 \mathrm{H}, \mathrm{d}, J=6.9 \mathrm{~Hz}), 9.96(1 \mathrm{H}, \mathrm{s})$. Anal. Calcd for $\mathrm{C}_{28} \mathrm{H}_{31} \mathrm{~N}_{4} \mathrm{O}_{5} \mathrm{~F}_{3}: \mathrm{C} ; 59.99, \mathrm{H}$; 5.57, N; 9.99. Found: $\mathrm{C} ; 59.79, \mathrm{H} ; 5.71, \mathrm{~N} ;$ 9.73. LC-MS: $\mathrm{m} / \mathrm{z}=561\left(\mathrm{MH}^{+}\right)$.

\section{6-Ethyl- $N$-[1-(hydroxyacetyl)piperidin-4-yl]-1-methyl-5-[(phenylcarbonyl)amino]} -3-(2,2,2-trifluoroethoxy)-1H-pyrrolo[3,2-b]pyridine-2-carboxamide (25e)

Yield $46 \%$, white crystals. mp. $165{ }^{\circ} \mathrm{C}$ (recrystallized from hexane/AcOEt). ${ }^{1} \mathrm{H}$ NMR (DMSO- $\left.d_{6}\right) \delta 1.23(3 \mathrm{H}, \mathrm{t}, J=7.5 \mathrm{~Hz}), 1.31-1.53(2 \mathrm{H}, \mathrm{m}), 1.84-1.96(2 \mathrm{H}, \mathrm{m}), 2.71$ $(2 \mathrm{H}, \mathrm{q}, J=7.5 \mathrm{~Hz}), 2.80-2.96(1 \mathrm{H}, \mathrm{m}), 3.04-3.20(1 \mathrm{H}, \mathrm{m}), 3.62-3.77(1 \mathrm{H}, \mathrm{m}), 3.94(3 \mathrm{H}$, s), 4.02-4.16 (3H, m), 4.19-4.30 (1H, m), $4.54(1 \mathrm{H}, \mathrm{t}, J=5.5 \mathrm{~Hz}), 5.23(2 \mathrm{H}, \mathrm{q}, J=8.9$ $\mathrm{Hz}), 7.47-7.65(3 \mathrm{H}, \mathrm{m}), 7.80(1 \mathrm{H}, \mathrm{d}, J=7.7 \mathrm{~Hz}), 7.95-8.05(3 \mathrm{H}, \mathrm{m}), 10.52(1 \mathrm{H}, \mathrm{s})$. Anal. Calcd for $\mathrm{C}_{27} \mathrm{H}_{30} \mathrm{~F}_{3} \mathrm{~N}_{5} \mathrm{O}_{5} \bullet 0.30 \mathrm{H}_{2} \mathrm{O}: \mathrm{C}, 57.20 ; \mathrm{H}, 5.44 ; \mathrm{N}, 12.35$. Found: C, 57.32; H, 5.58; N, 12.12. LC-MS: $\mathrm{m} / \mathrm{z}=562\left(\mathrm{MH}^{+}\right)$.

\section{3-Ethyl- $N$-[1-(hydroxyacetyl)piperidin-4-yl]-5-methyl-2-[(phenylcarbonyl)amino]}

\section{-7-(2,2,2-trifluoroethoxy)-5H-pyrrolo[2,3-b]pyrazine-6-carboxamide (25f)}

Yield $61 \%$, pale yellow crystals. mp. $142{ }^{\circ} \mathrm{C}$ (recrystallized from hexane/AcOEt). ${ }^{1} \mathrm{H}$ NMR (DMSO- $\left.d_{6}\right) \delta 1.28(3 \mathrm{H}, \mathrm{t}, J=7.5 \mathrm{~Hz}), 1.33-1.58(2 \mathrm{H}, \mathrm{m}), 1.84-1.99(2 \mathrm{H}, \mathrm{m})$, 2.81-2.98 (3H, m), 3.06-3.21 (1H, m), 3.62-3.76 (1H, m), $3.97(3 \mathrm{H}, \mathrm{s}), 4.01-4.18(3 \mathrm{H}$, m), 4.18-4.32 (1H, m), $4.54(1 \mathrm{H}, \mathrm{t}, J=5.5 \mathrm{~Hz}), 5.20(2 \mathrm{H}, \mathrm{q}, J=8.9 \mathrm{~Hz}), 7.49-7.69(3 \mathrm{H}$, m), $7.95(1 \mathrm{H}, \mathrm{d}, J=7.6 \mathrm{~Hz}), 7.99-8.10(2 \mathrm{H}, \mathrm{m}), 10.79(1 \mathrm{H}, \mathrm{s})$. Anal. Calcd for $\mathrm{C}_{26} \mathrm{H}_{29} \mathrm{~N}_{6} \mathrm{O}_{5} \mathrm{~F}_{3} \cdot \mathrm{H}_{2} \mathrm{O}: \mathrm{C}, 54.64 ; \mathrm{H}, 5.29 ; \mathrm{N}, 14.70$. Found: C, 55.02; H, 5.18; N, 14.81. LC-MS: $\mathrm{m} / \mathrm{z}=563\left(\mathrm{MH}^{+}\right)$.

\section{2-Ethyl- $N$-[1-(hydroxyacetyl)piperidin-4-yl]-7-methyl-4-oxo-3-(2-oxo-2-phenylethyl} )-5-(2,2,2-trifluoroethoxy)-4,7-dihydro-3H-pyrrolo[2,3-d]pyrimidine-6carboxamide (25g)

A mixture of $25 \mathrm{a}$ (300 mg, $0.65 \mathrm{mmol}), \mathrm{K}_{2} \mathrm{CO}_{3}(135 \mathrm{mg}, 0.98 \mathrm{mmol})$, DMF (1.0 $\mathrm{mL}) / \mathrm{DME}(4.0 \mathrm{~mL})$ was stirred at $0{ }^{\circ} \mathrm{C}$ for $30 \mathrm{~min}$. $\mathrm{LiBr}(114 \mathrm{mg}, 1.3 \mathrm{mmol})$ was added, and the mixture was stirred at room temperature for $30 \mathrm{~min}$. Phenacyl bromide 
(260 mg, $1.3 \mathrm{mmol}$ ) was added, and the reaction mixture was stirred at $60{ }^{\circ} \mathrm{C}$ for $13.5 \mathrm{~h}$ followed by addition of DMF $(1.0 \mathrm{~mL})$. The mixture was stirred at $60^{\circ} \mathrm{C}$ for $1.5 \mathrm{~h}$, at 70 ${ }^{\circ} \mathrm{C}$ for $2.5 \mathrm{~h}$, and at $80{ }^{\circ} \mathrm{C}$ for $20 \mathrm{~h}$. The mixture was diluted with water, and extracted twice with AcOEt. The extracts were combined, washed with brine, dried over $\mathrm{MgSO}_{4}$ and concentrated in vacuo. The residue was purified by silica gel column chromatography (hexane/AcOEt $=2 / 3$ to AcOEt) and then aminosilica gel column chromatography (hexane/AcOEt $=2 / 3$ to AcOEt), and recrystallized from hexane/AcOEt to give the title compound (53 mg, 14\%) as white crystals. mp $154{ }^{\circ} \mathrm{C}$. ${ }^{1} \mathrm{H}$ NMR (DMSO- $\left.d_{6}\right) \delta$ 1.16-1.55 (5 H, m), 1.77-2.00 (2 H, m), 2.66-2.93 (3 H, m), 3.03-3.20 (1 H, m), 3.60-3.78 (1 H, m), 3.83-3.95 (3 H, m), 3.97-4.16 (3 H, m), 4.16-4.35 (1 H, m), $4.53(1 \mathrm{H}, \mathrm{t}, J=5.5 \mathrm{~Hz}), 5.09(2 \mathrm{H}, \mathrm{q}, J=9.1 \mathrm{~Hz}), 5.73(2 \mathrm{H}, \mathrm{s})$, $7.50(1 \mathrm{H}, \mathrm{d}, J=7.7 \mathrm{~Hz}), 7.56-7.68(2 \mathrm{H}, \mathrm{m}), 7.69-7.83(1 \mathrm{H}, \mathrm{m}), 8.12(2 \mathrm{H}, \mathrm{d}, J=7.2$ $\mathrm{Hz}$ ). Anal. Calcd for $\mathrm{C}_{27} \mathrm{H}_{30} \mathrm{~F}_{3} \mathrm{~N}_{5} \mathrm{O}_{6}: \mathrm{C} ; 56.15, \mathrm{H} ; 5.24, \mathrm{~N} ; 12.13$. Found: $\mathrm{C} ; 55.87, \mathrm{H}$; 5.28, N; 11.98. LC-MS: $\mathrm{m} / \mathrm{z}=578\left(\mathrm{MH}^{+}\right)$. 


\section{Assay protocols}

\section{Gli-luciferase assay}

NIH3T3/Gli-luc cells were maintained in DMEM containing 10\% FBS, $500-\mu \mathrm{g} / \mathrm{mL} \mathrm{G} 418$, and $0.1 \%$ gentamicin solution (Invitrogen Corp [Carlsbad, CA, USA]). The cells were plated onto collagen-coated 384-well plates at $7.5 \mathrm{x}$ $10^{3}$ cells/well and cultured overnight in $25 \mu \mathrm{L}$ of DMEM containing 10\% FBS under 5\% $\mathrm{CO}_{2}$ at $37{ }^{\circ} \mathrm{C}$. After incubation, $20 \mu \mathrm{L}$ of recombinant mouse Shh-N $(2.5 \mu \mathrm{g} / \mathrm{mL}$ in DMEM containing $2 \%$ FBS) and $5 \mu \mathrm{L}$ of a serially diluted the compounds $10 \mathrm{x}$ solution (0.0003 to $10 \mu \mathrm{M}$ in DMEM) were added to the culture to achieve the final concentrations of $5.8 \% \mathrm{FBS}, 1-\mu \mathrm{g} / \mathrm{mL}$ of Shh-N, and 0.03 to $1000 \mathrm{nM}$ of the compounds ( $n=4$ wells per concentration). The cells were then incubated for an additional 48 hours. To determine the window of the assay, the cells were incubated in the media containing $0.1 \%$ DMSO with or without $1 \mu \mathrm{g} / \mathrm{mL}$ Shh-N $(0 \%$ or $100 \%$ inhibition control, respectively ( $\mathrm{n}=10$ wells). The luciferase activities of reporter cells were measured by Bright-Glo ${ }^{\mathrm{TM}}$ (Promega Corp [Madison, WI, USA]) using the EnVision ${ }^{\circledR}$ plate leader (PerkinElmer, Inc [Waltham, MA, USA]).

\section{Smo binding assay}

$293 \mathrm{~T}$ cells were transfected with pCMV-HA/hSmo using Lipofectamine reagent (Lipofectamine ${ }^{\mathrm{TM}} 2000$, Invitrogen). In brief, $45 \mu \mathrm{L}$ of Lipofectamine 2000 and 22.5 $\mu \mathrm{g}$ of pCMV-HA/hSmo were each incubated in $1.5 \mathrm{~mL}$ of Opti-MEM I media (Invitrogen) at room temperature for 5 minutes and were mixed together. The mixture was incubated for 20 minutes at room temperature after which it was added to $6 \times 10^{6}$ $293 \mathrm{~T}$ cells in $15 \mathrm{~mL}$ of culture medium in a $75 \mathrm{~cm}^{2}$ cell culture flask. After overnight incubation under $5 \% \mathrm{CO}_{2}$ at $37{ }^{\circ} \mathrm{C}$, cells were detached using Versene (Invitrogen) and resuspended in culture medium. The suspended cells were added to a 96-well plate at $6 \times 10^{4}$ cells/well. After removing the media from each well, $25 \mu \mathrm{L}$ of a $2 \times$ stock solution of the compounds and $25 \mu \mathrm{L}$ of BODIPY-cyclopamine (4 $\mathrm{nM}$ in DMEM containing $1 \%$ FBS) were added to the culture which was incubated for $1 \mathrm{~h}(\mathrm{n}=3$ wells per concentration). Final concentrations were $0.03-1000 \mathrm{nM}$ for the compounds and 2 $\mathrm{nM}$ for BODIPY-cyclopamine. To define the assay window, $25 \mu \mathrm{L}$ of media or $25 \mu \mathrm{L}$ of $2 \times$ cyclopamine solution (final concentration $1 \mu \mathrm{M}$ ) was added to the culture in addition to $25 \mu \mathrm{L}$ of BODIPY cyclopamine to serve as $0 \%$ or $100 \%$ inhibition controls ( $\mathrm{n}=5$ wells), respectively. After incubation, cells were detached using Versene and were resuspended in PBS supplemented with 2\% FBS. Cyclopamine binding 
competition with the compounds was determined by measuring the intensity of cell fluorescence using the Guava easyCyte System (Millipore Corp, Billerica, MA, USA).

\section{In vivo pharmacodynamic assay}

In vivo $\mathrm{PD}$ assay was conducted by using the nude mice bearing human primary pancreatic tumor (PAN-04). The tumor line was established by Central Institute for Experimental Animals. The test compounds were orally administered twice a day. After $24 \mathrm{~h}$ from the first administration, the tumors were extirpated and treated with RNAlater (Ambion). Total RNA samples were isolated using RNeasy Mini kit (Qiagen), and the first strand cDNA samples were prepared using the high capacity cDNA transcription kit (Applied Biosystems). The primer sets ofqPCR for quantification of stromal Gli1 mRNA were as follows (Applied Biosystems): Mm00494645_m1 (mouse Gli1), 4352339E (mouse GAPDH).

\section{In vivo anti-tumor test}

Anti-tumor effects of compounds were evaluated using a mouse medulloblastoma allogeneic transplantation model ${ }^{29}$ in which the medulloblastoma spontaneously occurred in the cerebellum of 7-9-week-old Patch 1 (+/-) and p53 (-/-) double mutant mice. Patch 1 gene mutant mice (Ptch1tm1Mps/J) were purchased from The Jackson Laboratory (Bar Harbor, ME) and p53 gene mutant mice (P53N4-M, B6.129-Trp53tm/BrdN4) were purchased from Taconic (Hudson, NY). Medulloblastoma tumors were subcutaneously transplanted into nude mice from Charles river laboratories (Yokohama, Japan; CAnN.Cg-Foxn1nu/CrlCrlj), and allograft tumors, following several serial passages in vivo, were used for compound testing. To examine the anti-tumor activity of compound 22d, animals bearing tumors with an average size of $150-250 \mathrm{~mm}^{3}$ were treated with compound $22 \mathrm{~d}(0.5 \%$ methylcellulose suspension) twice daily for 2 weeks. The tumor size was measured with an electronic vernier caliper, and tumor volume was calculated based on the longest (a) and shortest (b) tumor dimensions using the formula $\mathrm{V}=\left(\mathrm{a} \times \mathrm{b}^{2}\right) / 2$. The tumor growth rate $(\mathrm{T} / \mathrm{C} \%)$ was calculated as the mean values for $\left[\right.$ Treated $\left(\mathrm{V}_{\text {end }}-\mathrm{V}_{\text {start }}\right) /$ Control $\left.\left(\mathrm{V}_{\text {end }}-\mathrm{V}_{\text {start }}\right)\right] \times 100$.

\section{In vitro metabolism with hepatic microsomes}

Metabolic stability was evaluated both in mouse and human microsomes and used according to the manufacturer's instructions. Liver microsomes were purchased from Xenotech, LLC, Lenexa, KS, USA. An incubation mixture consisted of microsomes in $50 \mathrm{mmol} / \mathrm{L}$ of $\mathrm{KH}_{2} \mathrm{PO}_{4} / \mathrm{K}_{2} \mathrm{HPO}_{4}$ phosphate buffer $(\mathrm{pH} 7.4)$ and $1 \mu \mathrm{mol} / \mathrm{L}$ of test 
compound. The concentration of microsomes was $0.2 \mathrm{mg}$ protein $/ \mathrm{mL}$. An NADPH-generating system containing $25 \mathrm{mmol} / \mathrm{L} \quad \mathrm{MgCl}_{2}, 25 \mathrm{mmol} / \mathrm{L}$ glucose-6-phosphate, $2.5 \mathrm{mmol} / \mathrm{L}$ beta-NADP+, and $7.5 \mathrm{unit} / \mathrm{mL}$ glucose-6-phosphate dehydrogenase was added to the incubation mixture with a $20 \%$ volume of the reaction mixture to initiate the enzyme reaction. After the addition of the NADPH-generating system, the mixture was incubated at $37{ }^{\circ} \mathrm{C}$. The reaction was terminated by the addition of $\mathrm{MeCN}$ equivalent to the volume of the reaction mixture. Test compounds in the reaction mixtures were quantified by HPLC equipped with a UV detector or LC-MS/MS. To determine metabolic stabilities, chromatograms were analyzed for parent compound disappearance from the reaction mixtures.

\section{Pharmacokinetic studies in mice}

Test compounds were administered at a dose of $10 \mathrm{mg} / \mathrm{kg}$ as a cassette dosing to nonfasted mice. After the oral administration, blood samples were collected. The blood samples were centrifuged to obtain the plasma fraction. The plasma samples were deproteinized with $\mathrm{MeCN}$ containing an internal standard. After centrifugation, the supernatant was diluted with a mixture of $10 \mathrm{mmol} / \mathrm{L} \mathrm{HCOONH}_{4}$ containing $0.2 \%$ formic acid and $\mathrm{MeCN}$ containing $0.2 \%$ formic acid $(9: 1, \mathrm{v} / \mathrm{v})$, and centrifuged again. The compound concentrations in the supernatant were measured by LC/MS/MS.

\section{Pharmacokinetic studies in rats and dogs}

Compounds 22d was administered to fed rats and dogs. Plasma samples were collected after oral $(10 \mathrm{mg} / \mathrm{kg})$ and intravenous $(1 \mathrm{mg} / \mathrm{kg})$ administration and were deproteinized with methanol containing an internal standard. After centrifugation, the supernatant was diluted with a mixture of $0.01 \mathrm{~mol} / \mathrm{L}$ ammonium formate solution and $[\mathrm{MeCN} /$ formic acid (100:0.2, v/v)] (7:3, v/v) and centrifuged again. The compound concentrations in the supernatant were measured by LC-MS/MS.

\section{$\mathrm{X}$-ray structure analysis}

Crystal data for 22d: $\mathrm{C}_{28} \mathrm{H}_{31} \mathrm{~F}_{3} \mathrm{~N}_{4} \mathrm{O}_{6} \cdot 0.1 \mathrm{H}_{2} \mathrm{O}, \mathrm{MW}=578.37$; crystal size, $0.41 \mathrm{x}$ $0.20 \times 0.14 \mathrm{~mm}$; colorless, prism; monoclinic, space group $P 2_{1} / \mathrm{c}, a=11.6375(2) \AA, b=$ 18.6948(3) $\AA, c=25.8181(5) \AA, \alpha=\gamma=90^{\circ}, \beta=100.8640(7)^{\circ}, V=5516.33(17) \AA^{3}, Z=$ $8, D x=1.393 \mathrm{~g} / \mathrm{cm}^{3}, T=100 \mathrm{~K}, \mu=0.956 \mathrm{~mm}^{-1}, \lambda=1.54187 \AA, R_{1}=0.064, w R_{2}=$ 0.181 .

Crystal data for 25b: $\mathrm{C}_{28} \mathrm{H}_{31} \mathrm{~F}_{3} \mathrm{~N}_{4} \mathrm{O}_{5} \cdot 2 \mathrm{H}_{2} \mathrm{O}, \mathrm{MW}=596.60$; crystal size, $0.22 \times 0.09$ x $0.08 \mathrm{~mm}$; colorless, block; triclinic, space group $P-1, a=9.88809(18) \AA, b=$ 
11.9889(3) $\AA, c=13.0792(3) \AA, \alpha=112.612(8)^{\circ}, \beta=100.466(7)^{\circ}, \gamma=91.845(7)^{\circ}, V=$ $1398.57(11) \AA^{3}, Z=2, D x=1.417 \mathrm{~g} / \mathrm{cm}^{3}, T=100 \mathrm{~K}, \mu=0.982 \mathrm{~mm}^{-1}, \lambda=1.54187 \AA, R_{1}$ $=0.041, w R_{2}=0.095$.

Crystal data for 25d: $\mathrm{C}_{28} \mathrm{H}_{31} \mathrm{~F}_{3} \mathrm{~N}_{4} \mathrm{O}_{5}, \mathrm{MW}=560.57$; crystal size, 0.17 x $0.13 \mathrm{x}$ $0.04 \mathrm{~mm}$; colorless, platelet; triclinic, space group $P-1, a=9.29308(17) \AA, b=$ 9.62000(17) $\AA, c=16.0576(3) \AA, \alpha=75.445(6)^{\circ}, \beta=81.749(6)^{\circ}, \gamma=74.270(6)^{\circ}, V=$ $1333.05(7) \AA^{3}, Z=2, D x=1.396 \mathrm{~g} / \mathrm{cm}^{3}, T=100 \mathrm{~K}, \mu=0.938 \mathrm{~mm}^{-1}, \lambda=1.54187 \AA, R_{1}$ $=0.043, w R_{2}=0.111$.

Crystal data for 25e: $\mathrm{C}_{27} \mathrm{H}_{30} \mathrm{~F}_{3} \mathrm{~N}_{5} \mathrm{O}_{5}, M W=561.56$; crystal size, $0.16 \times 0.08 \mathrm{x}$ $0.03 \mathrm{~mm}$; colorless, platelet; triclinic, space group $P-1, a=9.2592(3) \AA, b=9.6488(3)$ $\AA, c=16.0297(4) \AA, \alpha=76.213(6)^{\circ}, \beta=82.549(6)^{\circ}, \gamma=73.877(6)^{\circ}, V=1333.03(8) \AA^{3}$, $Z=2, D x=1.399 \mathrm{~g} / \mathrm{cm}^{3}, T=100 \mathrm{~K}, \mu=0.951 \mathrm{~mm}^{-1}, \lambda=1.54187 \AA, R_{1}=0.055, w R_{2}=$ 0.155 .

All measurements were made on a Rigaku R-AXIS RAPID-191R diffractometer using graphite monochromated $\mathrm{Cu}-\mathrm{K} \alpha$ radiation. The structure was solved by direct methods with SHELXS-9 $97^{30}$ and was refined using full-matrix least-squares on $F^{2}$ with SHELXL-9 $7^{30}$. All non-H atoms were refined with anisotropic displacement parameters. CCDC 865214 for compound 22d, 1027998 for compound 25b, 1027990 for compound 25d and 1028036 for compound 25e contain the supplementary crystallographic data for this paper. These data can be obtained free of charge from The Cambridge Crystallographic Data Centre via http://www.ccdc.cam.ac.uk/Community/Requestastructure/Pages/DataRequest.aspx?. 


\section{References}

1) Köhler G, Milstein C. Nature 1975, 256, 495-497.

2) (a) Wu P.; Nielsen T. E.; Clausen M. H. Trends Pharmacol. Sci., 2015, 36, 422-439.

(b) Roskoski Jr. R.; Pharmacol. Res. 2015, 100, 1-23.

3) (a) Druker, B. J.; Tamura, S.; Buchdunger, E.; Ohno, S.; Segal, G. M.; Fanning, S.; Zimmermann, J.; Lydon, N. B. Nat. Med. 1996, 2, 561-566. (b) Thomas S., William B., Patricia P., W. Todd M., Bayard C., John K., Science, 2000, 289, 1938-1942.

4) Barker, A. J.; Gibson, K. H.; Grundy, W.; Godfrey, A. A.; Barlow, J.J.; Healy, M. P.; Woodburn, J. R.; Ashton, S. E.; Curry, B. J.; Scarlett, L.; Henthorn, L.; Richards, L. Bioorg. Med. Chem. Lett. 2001, 11, 1911-1914.

5) Thayer S. P.; di Magliano M. P.; Heiser P. W.; Nielsen C. M., Roberts D. J.; Lauwers G. Y.; Qi Y. P.; Gysin S.; Fernandez-del Castillo C.; Yajnik V.; Antoniu B.; McMahon M.; Warshaw A. L.; Hebrok, M. Nature 2003, 425, 851-856.

6) Stone, D. M.; Hynes, M.; Armanini, M., Swanson, T. A.; Gu, Q.; Johnson, R. L.; Scott, M. P.; Pennica, D.; Goddard, A., Phillips, H.; Noll, M.; Hooper, J. E.; Sauvage, F. and Rosenthal, A. Nature, 1996, 384, 129-134.

7) Tian, H.; Callahan, C. A.; DuPree, K. J.; Darbonne, W. C.; Ahn, C. P.; Scales, S. J. and Sauvage, F. Proc. Natl. Acad. Sci. USA, 2009, 106(11), 4254-4259.

8) Berman, D. M.; Karhadkar, S. S.; Hallahan, A. R.; Pritchard, J. I.; Eberhart, C. G.; Watkins, D. N.; Chen, J. K.; Cooper, M. K.; Taipale, J.; Olson, J. M.; Beachy, P. A. Science, 2002, 297, 1559-1561.

9) Epstein, H. E. Nat. Rev. Cancer, 2008, 8, 743-754.

10) Yauch, R. L.; Gould, S. E.; Scales, S. J.; Tang, T.; Tian, H.; Ahn, C. P.; Marshall, D.; Fu, L.; Januario, T.; Kallop, D.; Nannini-Pepe, M.; Kotkow, K.; Marsters Jr, J. C.; Rubin, L. L.; Sauvage, F. J. Nature, 2008, 455, 406-410.

11) Mazumdar, T.; DeVecchio, J.; Shi, T.; Jones, J.; Agyeman, A.; Houghton, J. A. Cancer Res., 2011, 71, 1092-1102.

12) Shaw, A.; Bushman, W. J. Urol. 2007, 177, 832-838.

13) Thayer, S. P.; Magliano, M. P.; Heiser, P. W.; Nielsen, C. M.; Roberts, D. J.; Lauwers, G. Y.; Qi, Y. P.; Gysin, S.; Castillo, C. F.; Yajnik, V.; Antoniu, B.; McMahon, M.; Warshaw, A. L.; Hebrok, M. Nature, 2003, 425, 851-856.

14) (a) Taipale, J. Chen, J. K.; Cooper, M. K.; Wang, B.; Mann, R. K.; Milenkovic, L.; Scott, M. P.; Beachy, P. A. Nature 2000, 406, 1005-1009. (b) Karhadkar, S. S.; Bova, G. S.; Abdallah, N.; Dhara, S.; Gardner, D.; Maitra, A.; Isaacs, J. T.; Berman, D. M.; Beachy, P. A. Nature 2004, 431, 707-712. 
15) Robarge, K. D.; Brunton, S. A.; Castanedo, G. M.; Cui, Y.; Dina, M. S.; Goldsmith, R.; Gould, S. E.; Guichert, O.; Gunzner, J. L.; Halladay, J.; Jia, W.; Khojasteh, C.; Koehler, M. F.T.; Kotkow, K.; La, H.; LaLonde, R. L.; Lau, K.; Lee, L.; Marshall, D.; Marsters Jr, J. C.; Murray, L. J.; Qian, C.; Rubin, L. L.; Salphati, L.; Stanley, M. S.; Stibbard, J. H.A.; Sutherlin, D. P.; Ubhayaker, S.; Wang, S.; Wong, S. and Xie, M. Bioorg. Med. Chem. Lett. 2009, 19, 5576-5581.

16) Pan, S.; Wu, X.; Jiang, J.; Gao, W.; Wan, Y.; Cheng, D.; Han, D.; Liu, J.; Englund, N. P.; Wang, Y.; Peukert, S.; Miller-Moslin, K.; Yuan, J.; Guo, R.; Matsumoto, M.; Vattay, A.; Jiang, Y.; Tsao, J.; Sun, F.; Pferdekamper, A. C.; Dodd, S.; Tuntland, T.; Maniara, W.; Kelleher, J. F., III; Yao, Y.; Warmuth, M.; Williams, J.; Dorsch, M. ACS Med. Chem. Lett., 2010, 3, 130-134.

17) Tremblay, M. R.; Lescarbeau, A.; Grogan, M. J.; Tan, E.; Lin, G.; Austad, B. C.; Yu, L.; Behnke, M. L.; Nair, S. J.; Hagel, M.; White, K.; Conley, J.; Manna, J. D.; Alvarez-Diez, T. M.; Hoyt, J.; Woodward, C. N.; Sydor, J. R.; Pink, M.; MacDougall, J.; Campbell, M. J.; Cushing, J.; Ferguson, J.; Curtis, M. S.; McGovern, K.; Read, M. A.; Palombella, V. J.; Adams, J.; Castro, A. C. J. Med. Chem. 2009, 52, 4400-4418.

18) Peukert, S.; He, F.; Dai, M.; Zhang, R.; Sun, Y.; Miller-Moslin, K.; McEwan, M.; Lagu, B.; Wang, K.; Yusuff, N.; Bourret, A.; Ramamurthy, A.; Maniara, W.; Amaral, A.; Vattay, A.; Wang, A.; Guo, R.; Yuan, J.; Green, J.; Williams, J.; Buonamici, S.; Kelleher, III, J. F.; Dorsch, M. ChemMedChem 2013, 8, 1261-1265.

19) Munchhof, M. J.; Li, Q.; Shavnya, A.; Borzillo, G. V.; Boyden, T. L.; Jones, C. S.; LaGreca, S. D.; Martinez-Alsina, L.; Patel, N.; Pelletier, K.; Reiter, L. A.; Robbins, M. D.; Tkalcevic, G. T. ACS Med. Chem. Lett., 2012, 3, 106-111.

20) Zaidi, A. H.; Komatsu, Y.; Kelly, L. A.; Malhotra, U.; Rotoloni, C.; Kosovec, J. E.; Zahoor, H.; Makielski, R.; Bhatt, A.; Hoppo, T.; Jobe B. A. Cancer Invest., 2013, 31, 480-489.

21) Williams, K. P.; Rayhorn, P.; Chi-Rosso, G.; Garber, E. A.; Strauch, K. L.; Horan, G. S.B.; Reilly, J. O.; Baker, D. P.; Taylor, F. R.; Koteliansky, V. and Pepinsky, R. B. Functional antagonists of sonic hedgehog reveal the importance of the $\mathrm{N}$ terminus for activity. J. Cell. Sci. 1999, 112 (23), 4405-4414.

22) Kerns, E. H.; Di, L. Drug-like properties: concepts, structure design and methods from ADME to toxicity optimization. Academic press, 2008.

23) (a) Ishikawa, M.; Ajito, K.; In Soyaku Shien Kenkyu no Tenbo; Torisawa Y. Ed.; CMC Publishing, Tokyo, 2008, 3-13. (b) Fujita, Y.; Yonehara, M.; Tetsuhashi, M.; Noguchi-Yachide, T.; Hashimoto, Y.; Ishikawa, M. Bioorg. Med. Chem. Lett. 2010, 18, 1194-1203. 
24) Dropinski, D. F.; Akiyama, T.; Einstein, M.; Habulihaz, B.; Doebber, T.; Berger, J. P.; Meinke P. T. and Shi, G. Q. Bioorg. Med. Chem. Lett. 2005, 15, 5035-5038.

25) (a) Hans-Joachim, B.; David, B.; Stefanie, B.; Manfred, K.; Bernd, K.; Klaus, M.; Ulrike, O.; Martin, S. ChemBioChem, 2004, 5, 637-643. (b) William, K. H. J. Med. Chem. 2008, 51(15), 4359-4369.

26) Liu, H; Ko, Sung-Bo; Hosien, H.; Curran, D. P. Tetrahedron Lett. 1995, 36, 8917-8920.

27) (a) Zhu, Y-F.; Wilcoxen, K.; Saunders, J.; Guo, Z.; Gao, Y.; Connors Jr., P. J.; Gross,

T. D.; Tucci, F. C.; Struthers, R. S.; Reinhart, G. J.; Xie, Q.; Chen, C. Bioorg. Med. Chem. Lett. 2002, 12, 403-406. (b) Gao, J.; Henry, R. F.; Pagano, T. G.; Duerst, R. W.; Souers, A. J. Tetrahedron Lett. 2007, 48, 7395-7398.

28) (a) Chang, C. A.; Chen, W.; Gilson, M. K. PNAS 2007, 104, 1540-1545. (b) Marshall, G. R. J. Comput. Aided Mol. Des. 2012, 26, 3-8.

Experimental section

29) Sasai, K.; Romer, J. T.; Lee, Y.; Finkelstein, D.; Fuller, C.; McKinnon, P. J. and Curran, T. Shh Pathway Activity Is Down-Regulated in Cultured Medulloblastoma Cells: Implications for Preclinical Studies. Cancer Res. 2006, 66, 4215-4222.

30) Sheldrick, G.M. Acta Cryst. A 2008, 64, 112. 


\section{List of publications (first author)}

1) Discovery of pyrrolo[3,2-c] quinoline-4-one derivatives as novel hedgehog signaling inhibitors

Ohashi, T.; Oguro, Y.; Tanaka, T.; Shiokawa, Z.; Shibata, S.; Satoh, Y.; Yamakawa, H.; Hattori, H.; Yamamoto, Y.; Kondo, S.; Miyamoto, M.; Tojo, H.; Baba, A.; Sasaki, S. Bioorg. Med. Chem. 2012, 20, 5496-5506.

2) Discovery of the investigational drug TAK-441, a pyrrolo[3,2-c]pyridine derivative, as a highly potent and orally active hedgehog signaling inhibitor: Modification of the core skeleton for improved solubility

Ohashi, T.; Oguro, Y.; Tanaka, T.; Shiokawa, Z.; Tanaka, Y.; Shibata, S.; Satoh, Y.; Yamakawa, H.; Hattori, H.; Yamamoto, Y.; Kondo, S.; Miyamoto, M.; Nishihara, M.; Ishimura, Y.; Tojo, H.; Baba, A.; Sasaki, S. Bioorg. Med. Chem. 2012, 20, 5507-5517.

3) Synthesis and evaluation of hedgehog signaling inhibitor with novel core system

Ohashi, T.; Tanaka, Y.; Shiokawa, Z.; Banno, H.; Tanaka, T.; Shibata, S.; Satoh, Y.; Yamakawa, H.; Yamamoto, Y.; Hattori, H.; Kondo, S.; Miyamoto, M.; Tojo, H.; Baba, A.; Sasaki, S. Bioorg. Med. Chem. 2015, 23, 4777-4791.

\section{List of other publications (including name)}

1) Design and Synthesis of Pyrrolo[3,2- $d]$ pyrimidine Human Epidermal Growth Factor Receptor 2 (HER2)/Epidermal Growth Factor Receptor (EGFR) Dual Inhibitors: Exploration of Novel Back-Pocket Binders

Kawakita, Y.; Banno, H.; Ohashi, T.; Tamura, T.; Yusa, T.; Nakayama, A.; Miki, H.; Iwata, H.; Kamiguchi, H.; Tanaka, T.; Habuka, N.; Sogabe, S.; Ohta, Y.; Ishikawa, T. J. Med. Chem. 2012, 55, 3975-3991.

2) Design and synthesis of novel pyrimido[4,5-b]azepine derivatives as HER2/EGFR dual inhibitors

Kawakita, Y.; Seto, M.; Ohashi, T.; Tamura, T.; Yusa, T.; Miki, H.; Iwata, H.; Kamiguchi, H.; Tanaka, T.; Sogabe, S.; Ohta, Y. Ishikawa, T. Bioorg. Med. Chem. 2013, 21, 2250-2261.

3) Design and Synthesis of Novel DFG-Out RAF/Vascular Endothelial Growth Factor Receptor 2 (VEGFR2) Inhibitors. 1. Exploration of [5,6]-Fused Bicyclic Scaffolds Okaniwa, M.; Hirose, M.; Imada, T.; Ohashi, T.; Hayashi, Y.; Miyazaki, T.; Arita, T.; Yabuki, M.; Kakoi, K.; Kato, J.; Takagi, T.; Kawamoto, T.; Yao, S.; Sumita, A.; 
Tsutsumi, S.; Tottori, T.; Oki, H.; Sang, B-C.; Yano, J.; Aertgeerts, K.; Yoshida, S.; Ishikawa, T. J. Med. Chem. 2012, 55, 3452-3478.

4) Design and synthesis of novel DFG-out RAF/vascular endothelial growth factor receptor 2 (VEGFR2) inhibitors: 2. Synthesis and characterization of a novel imide-type prodrug for improving oral absorption

Okaniwa, M.; Imada, T.; Ohashi, T.; Miyazaki, T.; Arita, T.; Yabuki, M.; Sumita, A.; Tsutsumi, S.; Higashikawa, K.; Takagi, T.; Kawamoto, T.; Inui, Y.; Yoshida, S.; Ishikawa, T. Bioorg. Med. Chem. 2012, 20, 4680-4692.

5) Design and synthesis of novel DFG-out RAF/vascular endothelial growth factor receptor 2 (VEGFR2) inhibitors: 3. Evaluation of 5-amino-linked thiazolo $[5,4-d]$ pyrimidine and thiazolo[ $[5,4-b]$ pyridine derivatives

Hirose, M.; Okaniwa, M.; Miyazaki, T.; Imada, T.; Ohashi, T.; Tanaka, Y.; Arita, T.; Yabuki, M.; Kawamoto, T.; Tsutsumi, S.; Sumita, A.; Takagi, T.; Sang, B-C.; Yano, J.; Aertgeerts, K.; Yoshida, S.; Ishikawa, T. Bioorg. Med. Chem. 2012, 20, 5600-5615.

6) Synthetic Studies of Norzoanthamine. Preparation of the Diene-yne-diene Precursor of an ABC-ring Fragment

Irifune, T.; Ohashi, T.; Ichino, T.; Sakai, E.; Suenaga, K.; Uemura, D. Chem. Lett. 2005, 34, 1058-1059. 
